



\title{
Gebruik van Natuurverbinding Laarderhoogt door zoogdieren en het effect van medegebruik door de mens
}

E.A. van der Grift ${ }^{1}$, T. Denayère ${ }^{2}$, M. Waanders ${ }^{2}$, J. Willemsen ${ }^{2}$ \& D.R. Lammertsma ${ }^{1}$

\author{
1 Wageningen Environmental Research \\ 2 RPS advies- en ingenieursbureau bv
}

Dit onderzoek is uitgevoerd door RPS advies- en ingenieursbureau bv en Wageningen Environmental Research in opdracht van de Provincie Noord-Holland en gefinancierd door de Provincie Noord-Holland, Rijkswaterstaat en het Goois Natuurreservaat.

Wageningen Environmental Research

Wageningen, december 2020

Gereviewd door:

F.G.W.A. Ottburg BSc., onderzoeker Dierecologie, Wageningen Environmental Research

Akkoord voor publicatie:

M. Kluivers-Poodt, teamleider Dierecologie

Rapport 3044

ISSN 1566-7197 
Van der Grift, E.A., T. Denayère, M. Waanders, J. Willemsen \& D.R. Lammertsma, 2020. Gebruik van Natuurverbinding Laarderhoogt door zoogdieren en het effect van medegebruik door de mens.

Wageningen, Wageningen Environmental Research, Rapport 3044. 108 blz.; 66 fig.; 18 tab.; 18 ref.

In opdracht van de provincie Noord-Holland en haar partners - het Goois Natuurreservaat, Rijkswaterstaat en de gemeenten Laren en Blaricum - is het functioneren van Natuurbrug Laarderhoogt onderzocht met als doel om (1) vast te stellen of de natuurbrug goed functioneert voor de zoogdiersoorten die als doelsoort zijn aangewezen voor de natuurverbinding; (2) meer inzicht te verkrijgen in de effecten van het menselijk medegebruik op het gebruik van de natuurbrug door deze zoogdieren; en (3) te verkennen of er aanpassingen in de inrichting en het beheer van de natuurbrug gewenst zijn om het gebruik ervan door deze zoogdieren te optimaliseren.

Trefwoorden: versnippering, ontsnippering, barrièrewerking, mitigatie, faunapassage, natuurbrug, ecoduct, verkeersweg, Laarderhoogt, das, boommarter, ree, cameraval

Dit rapport is gratis te downloaden van https://doi.org/10.18174/537344 of op www.wur.nl/environmental-research (ga naar 'Wageningen Environmental Research' in de grijze balk onderaan). Wageningen Environmental Research verstrekt geen gedrukte exemplaren van rapporten.

(C) 2020 Wageningen Environmental Research (instituut binnen de rechtspersoon Stichting Wageningen Research), Postbus 47, 6700 AA Wageningen, T 03174807 00, www.wur.nl/environmental-research. Wageningen Environmental Research is onderdeel van Wageningen University \& Research.

- Overname, verveelvoudiging of openbaarmaking van deze uitgave is toegestaan mits met duidelijke bronvermelding.

- Overname, verveelvoudiging of openbaarmaking is niet toegestaan voor commerciële doeleinden en/of geldelijk gewin.

- Overname, verveelvoudiging of openbaarmaking is niet toegestaan voor die gedeelten van deze uitgave waarvan duidelijk is dat de auteursrechten liggen bij derden en/of zijn voorbehouden.

Wageningen Environmental Research aanvaardt geen aansprakelijkheid voor eventuele schade voortvloeiend uit het gebruik van de resultaten van dit onderzoek of de toepassing van de adviezen.

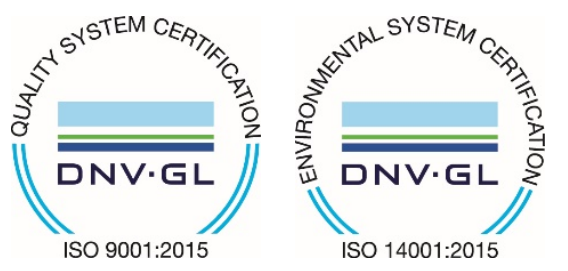

Wageningen Environmental Research werkt sinds 2003 met een ISO 9001 gecertificeerd kwaliteitsmanagementsysteem. In 2006 heeft Wageningen Environmental Research een milieuzorgsysteem geïmplementeerd, gecertificeerd volgens de norm ISO 14001.

Wageningen Environmental Research geeft via ISO 26000 invulling aan haar maatschappelijke verantwoordelijkheid.

Wageningen Environmental Research Rapport 3044 | ISSN 1566-7197

Foto omslag: (c) Edgar van der Grift / WENR 


\section{Inhoud}

$\begin{array}{ll}\text { Verantwoording } & 7\end{array}$

$\begin{array}{ll}\text { Samenvatting } & 9\end{array}$

$1 \quad$ Inleiding

1.1 Achtergrond 13

1.2 Doel van het onderzoek 14

$\begin{array}{lll}1.3 & \text { Onderzoeksvragen } & 15\end{array}$

$\begin{array}{lll}1.4 & \text { Leeswijzer } & 15\end{array}$

$\begin{array}{ll}\text { Natuurverbinding Laarderhoogt } & 16\end{array}$

2.1 Inleiding 16

2.2 Doel Naturverbinding Laarderhoogt $\quad 16$

$\begin{array}{lll}2.3 & \text { Doelsoorten } & 16\end{array}$

2.4 Kenmerken Natuurbrug Laarderhoogt $\quad 16$

2.5 Kenmerken Corridor Prinses Julianalaan $\quad 21$

$\begin{array}{lll}2.6 & \text { Kenmerken kleine faunatunnels } & 21\end{array}$

$\begin{array}{ll}\text { Methoden } & 25\end{array}$

3.1 Inleiding $\quad 25$

$\begin{array}{lll}3.2 & \text { Ontwerp van de studie } & 25\end{array}$

3.3 Toetsingskader $\quad 26$

3.4 Verzamelen gegevens $\quad 29$

$\begin{array}{ll}3.4 .1 & \text { Natuurbrug Laarderhoogt } \\ 3.4 .2 & 29\end{array}$

3.4.2 Referentieplekken 33

$\begin{array}{lll}3.4 .3 & \text { Corridor Prinses Julianalaan } & 37\end{array}$

$\begin{array}{lll}3.4 .4 & \text { Faunatunnels Leemzeulder } & 37\end{array}$

$\begin{array}{lll}\text { 3.4.5 Faunatunnels Boissevainweg } & 38\end{array}$

$\begin{array}{lll}3.5 & \text { Verwerken van de fotobeelden } & 38\end{array}$

$\begin{array}{lll}3.6 & \text { Analyse gegevens zoogdieren } & 40\end{array}$

$\begin{array}{lll}3.6 .1 & \text { Definities } & 40\end{array}$

3.6.2 Aantal passages op de natuurbrug $\quad 40$

3.6.3 Percentage bevestigde oversteken natuurbrug $\quad 41$

3.6.4 Passagefrequentie op de natuurbrug 41

3.6.5 Passagefrequentie op de referentieplekken 41

3.6.6 Vergelijking passagefrequentie natuurbrug versus omgeving 41

3.6.7 Trefkans op de natuurbrug $\quad 42$

3.6.8 Procentuele verdeling passages over het jaar $\quad 42$

3.6.9 Procentuele verdeling passages over het etmaal 43

3.6.10 Gemiddeld tijdstip van passage $\quad 43$

3.6.11 Verdeling van passages over lichttoestand $\quad 44$

3.6.12 Geslachtsverhouding $\quad 44$

3.6.13 Verdeling van passages over het jaar, per geslacht $\quad 44$

3.6.14 Leeftijdsverdeling $\quad 45$

3.6.15 Verdeling van passages over het jaar, per leeftijdsgroep 45

$\begin{array}{lll}3.6 .16 & \text { Loopwijze } & 45\end{array}$

3.6.17 Gedrag $\quad 46$

3.6.18 Passagefrequentie Corridor Prinses Julianalaan $\quad 46$

3.6.19 Passagefrequentie kleine faunatunnels 46

3.7 Analysegegevens mens en huisdier $\quad 46$ 
3.7.1 Aantal passages op de natuurbrug 46

3.7.2 Passagefrequentie op de natuurbrug 47

3.7.3 Procentuele verdeling passages over het etmaal 47

3.7.4 Procentuele verdeling illegale passages over het jaar $\quad 47$

3.7.5 Procentuele verdeling illegale passages over het etmaal 48

3.7.6 Vergelijking aantal illegale passages natuurbrug versus omgeving 48

3.8 Analyse effect menselijk medegebruik natuurbrug $\quad 48$

$\begin{array}{lll}3.9 & \text { Kanttekeningen bij de methoden } & 49\end{array}$

$4.1 \quad$ Inleiding $\quad 52$

4.2 Soorten $\quad 52$

4.3 Frequentie van passeren $\quad 56$

$\begin{array}{lll}4.4 & \text { Trefkans } & 57\end{array}$

4.5 Passagefrequentie natuurbrug versus omgeving $\quad 57$

4.6 Verdeling passages over het jaar $\quad 59$

$\begin{array}{lll}4.7 & \text { Verdeling passages over het etmaal } & 61\end{array}$

4.8 Gemiddeld tijdstip van passage $\quad 64$

4.9 Verdeling passages over lichttoestand $\quad 65$

$\begin{array}{lll}4.10 & \text { Geslachtsverhouding } & 67\end{array}$

$\begin{array}{lll}4.11 & \text { Leeftijdsverdeling } & 68\end{array}$

$\begin{array}{ll}4.12 \text { Loopwijze } & 70\end{array}$

$\begin{array}{ll}4.13 \text { Gedrag } & 71\end{array}$

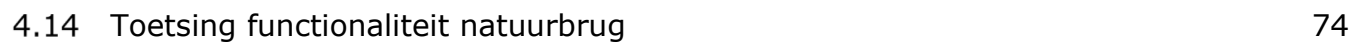

$\begin{array}{ll}4.15 & \text { Discussie }\end{array}$

$5 \quad$ Gebruik naturbrug door mens en huisdier $\quad \mathbf{8 0}$

$\begin{array}{lll}5.1 & \text { Inleiding } & 80\end{array}$

5.2 Gebruik van de natuurbrug door mensen $\quad 80$

$\begin{array}{lll}5.3 & \text { Gebruik van de natuurbrug door huisdieren } & 83\end{array}$

$\begin{array}{lll}5.4 & \text { Vergelijking natuurbrug en omgeving } & 85\end{array}$

6 Effect menselijk medegebruik van de natuurbrug op het gebruik door zoogdieren

$\begin{array}{lll}6.1 & \text { Inleiding } & 87\end{array}$

6.2 Aantal mensen en aantal dieren $\quad 87$

6.3 Aantal mensen en het tijdstip waarop dieren passeren 88

$\begin{array}{lll}6.4 & \text { Voorspellende waarde } & 89\end{array}$

$\begin{array}{lll}6.5 & \text { Drukke versus rustige dagen } & 90\end{array}$

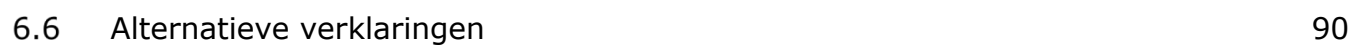

$\begin{array}{lll}7.1 & \text { Inleiding } & 91\end{array}$

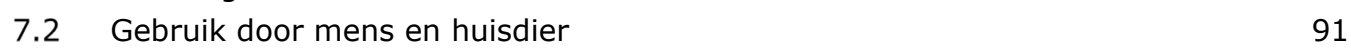

$\begin{array}{ll}7.3 \text { Gebruik door zoogdieren } & 91\end{array}$

$\begin{array}{lll}7.4 & \text { Frequentie van passages } & 91\end{array}$

$\begin{array}{lll}7.5 & \text { Trefkans } & 92\end{array}$

$\begin{array}{lll}7.6 & \text { Passagefrequentie corridor versus omgeving } & 94\end{array}$

$\begin{array}{lll}7.7 & \text { Discussie } & 94\end{array}$

$8 \quad$ Gebruik kleine faunatunnels $\quad 95$

$\begin{array}{lll}8.1 & \text { Inleiding } & 95\end{array}$

$\begin{array}{ll}8.2 \text { Leemzeulder } & 95\end{array}$

$\begin{array}{lll}8.3 & \text { Boissevainweg } & 95\end{array}$ 
10.1 Adviezen voor inrichting en beheer 99

10.2 Adviezen voor vervolgonderzoek

Dankwoord 101

Literatuur 102

Bijlage 1 Vegetatie natuurverbinding 103 



\section{Verantwoording}

Rapport: 3044

Projectnummer: 5200044254

Wageningen Environmental Research (WENR) hecht grote waarde aan de kwaliteit van zijn eindproducten. Een review van de rapporten op wetenschappelijke kwaliteit door een referent maakt standaard onderdeel uit van het kwaliteitsbeleid.

Akkoord Referent die het rapport heeft beoordeeld,

functie: $\quad$ Onderzoeker Dierecologie, Wageningen Environmental Research

naam: F.G.W.A. Ottburg BSc.

datum: 1 november 2020

Akkoord teamleider voor de inhoud,

naam: M. Kluivers-Poodt

datum: 19 november 2020 


\section{Samenvatting}

\section{Achtergrond}

Natuurbrug Laarderhoogt ligt ten zuidoosten van Laren en overspant rijksweg A1 en de langs deze snelweg gelegen parallelweg (zuid) en fietspad (noord), en de gemeentelijke weg Naarderstraat met de daarnaast gelegen fietspaden. Deze natuurverbinding heeft als doel om de natuurgebieden in het noordelijke deel van het Gooi te verbinden met die in het zuidelijk deel en op de Utrechtse Heuvelrug. De natuurverbinding is bedoeld voor diersoorten van bossen en heide op droge zandgronden. De natuurbrug heeft ook een verbindende functie voor mensen. Zowel wandelaars, fietsers als ruiters kunnen gebruikmaken van de natuurbrug.

Natuurbrug Laarderhoogt ligt, in tegenstelling tot veel andere ecoducten, in een sterk verstedelijkt gebied. De ontwerpruimte voor zowel de natuurbrug als de noordelijke en zuidelijke toeloop was hierdoor beperkt. Het ontwerp van de natuurverbinding wijkt in sommige opzichten dan ook af van natuurverbindingen die elders, op plekken met meer ruimte, zijn gerealiseerd. Wat betekent dit voor de functionaliteit van de natuurbrug? Maken de dieren waarvoor de brug bedoeld is er wel gebruik van? En als ze dat doen, is dit dan incidenteel of passeren ze de natuurbrug met regelmaat? Het gedeeltelijk openstellen van Natuurbrug Laarderhoogt voor mensen roept eveneens een aantal vragen op. Hoe beïnvloedt het menselijk medegebruik van de natuurbrug het gebruik ervan door de dieren? Passeren de dieren minder vaak op dagen dat er veel mensen zijn gepasseerd? Of zijn er effecten te zien op het moment of de manier warop de dieren de natuurbrug passeren?

Met deze achtergrond was het de wens van de provincie Noord-Holland en haar partners - het Goois Natuurreservaat, Rijkswaterstaat en de gemeenten Laren en Blaricum - om het functioneren van Natuurverbinding Laarderhoogt te laten onderzoeken. Met daarbij aandacht voor het gebruik van de natuurbrug door zowel dieren als mensen en de wijze waarop deze elkaar eventueel beïnvloeden. Enerzijds is dit dus een evaluatie van het functioneren van deze specifieke natuurverbinding, met haar bijzondere kenmerken, anderzijds biedt het de kans om meer kennis te verwerven over de effecten van het openstellen van natuurbruggen voor medegebruik door mensen.

\section{Doel van het onderzoek}

Het doel van het onderzoek is drieledig: (1) vaststellen of de natuurbrug goed functioneert voor de zoogdiersoorten die als doelsoort zijn aangewezen voor de natuurverbinding; (2) meer inzicht verkrijgen in de effecten van het menselijk medegebruik op het gebruik van de natuurbrug door deze zoogdieren; (3) verkennen of er aanpassingen in de inrichting en het beheer van de natuurbrug gewenst zijn om het gebruik ervan door deze zoogdieren te optimaliseren.

\footnotetext{
Afbakening van het onderzoek

Het onderzoek richt zich primair op zoogdieren die als doelsoort voor de natuurverbinding zijn aangewezen: ree, das en boommarter. Tijdens de monitoring van deze soorten is echter ook het gebruik door andere middelgrote zoogdieren vastgesteld, soorten dus die niet expliciet als doelsoort zijn aangewezen voor de natuurverbinding. Ook deze soorten zijn betrokken in het onderzoek. De toetsing van het functioneren van de natuurbrug is echter gebaseerd op het gebruik door de drie doelsoorten. Het onderzoek richt zich primair op het functioneren van de natuurbrug. Daarnaast gaat de aandacht ook uit naar het gebruik van (1) de ecologische verbindingszone aan de noordzijde van de natuurbrug (Corridor Prinses Julianalaan genoemd), (2) twee kleine faunapassages onder de Leemzeulder - een gemeentelijke weg - die deze verbindingszone met de Noorderheide moeten verbinden en (3) zes kleine faunapassages onder de Boissevainweg - een provinciale weg - die de Noorderheide met de Blaricummerheide moeten verbinden. Al deze maatregelen samen, dus van Westerheide tot aan Blaricummerheide, noemen we Natuurverbinding Laarderhoogt.
} 


\section{Werkwijze}

Allereerst is een toetsingskader opgesteld waarmee het gebruik van de natuurbrug kan worden geëvalueerd. Hierbij zijn meetbare doelen voor het gebruik door middelgrote zoogdieren geformuleerd. Het gebruik van de natuurbrug door middelgrote zoogdieren is vervolgens onderzocht met behulp van cameravallen. Om de vraag te kunnen beantwoorden of hiermee aan vooraf gestelde doelen voor het gebruik van de natuurbrug wordt voldaan, zijn gelijktijdig metingen met cameravallen gedaan op willekeurig gekozen referentieplekken in de natuurgebieden rondom de natuurbrug. Dit stelt ons in staat om de aan- of afwezigheid van een diersoort op de natuurbrug beter te duiden. Daarnaast biedt deze opzet de mogelijkheid om waargenomen activiteit op de natuurbrug te vergelijken met die van deze soorten in de omgeving.

In het onderzoek naar het effect van menselijk medegebruik op het gebruik van de natuurbrug door middelgrote zoogdieren is een vergelijking gemaakt tussen drukke en rustige dagen wat betreft het aantal mensen, en is onderzocht of het gebruik door middelgrote zoogdieren hieraan is gerelateerd. We hebben ons hierbij gericht op passagefrequentie, tijdstip van passeren, snelheid van passeren en het gedrag tijdens passeren.

Om te onderzoeken of middelgrote zoogdieren gebruikmaken van Corridor Prinses Julianalaan en hoe frequent dit gebruik dan is, is een veldstudie uitgevoerd met behulp van cameravallen. Om te onderzoeken of middelgrote zoogdieren gebruikmaken van de kleine faunatunnels bij de Leemzeulder en de Boissevainweg, en hoe frequent dit gebruik dan is, is een veldstudie uitgevoerd met behulp van cameravallen en sporenplaten.

Om vast te stellen of er verbeteringen mogelijk zijn wat de inrichting en het beheer van de natuurbrug betreft, is verkend voor welke soorten het gebruik van de natuurbrug achterblijft bij de verwachtingen. Vervolgens is onderzocht wat hiervoor mogelijke oorzaken zijn en welke maatregelen genomen kunnen worden om deze verwachtingen wel waar te maken. Het betreft hier een expertoordeel.

\section{Bevindingen}

Maken middelgrote zoogdieren gebruik van de natuurbrug, hoe frequent en op welke wijze doen zij dit en wordt hiermee aan vooraf gestelde doelen voor het gebruik van de natuurbrug voldaan?

- Natuurbrug Laarderhoogt functioneert in grote lijnen naar verwachting voor de drie doelsoorten ree, das en boommarter. Deze soorten maken alle gebruik van de faunavoorziening. Ree doet dat zeer frequent, gemiddeld tweemaal per dag. De das passeert gemiddeld eenmaal per week en de boommarter eenmaal per twee maanden. Ree en das passeren gemiddeld respectievelijk zeven- en twaalfmaal vaker dan op referentieplekken in de omgeving waar deze soorten zijn aangetroffen. Dit betekent dat er op de natuurbrug sprake is van een stuwingseffect: er passeren meer dieren dan je op basis van toeval mag verwachten. Voor boommarter geldt dit niet. De natuurbrug is dus door de doelsoorten gevonden, geaccepteerd en de vooraf gestelde doelen voor de frequentie van passeren zijn behaald. Dit illustreert dat natuurbruggen ook in sterk verstedelijkte gebieden functioneel kunnen zijn.

- De procentuele verdeling van het aantal passages van ree op de natuurbrug over het jaar wijkt niet sterk af van die in de omgeving. Wat betreft de verdeling van passages over het etmaal zijn er wel duidelijke verschillen. Op de natuurbrug zijn er in de vroege ochtend relatief weinig passages. Aan het begin van de avond is er een toename, maar het grootste deel van de passages vindt pas later in de nacht plaats. Ree passeert de natuurbrug later en vaker in donker in vergelijking met de omgeving. Omdat het aantal waarnemingen op de natuurbrug en/of in de omgeving beperkt was, konden de verdelingen van het aantal passages van das en boommarter over het jaar en over het etmaal niet goed worden vergeleken. Voor boommarter komt het gemiddelde tijdstip van passeren op de natuurbrug overeen met die in de omgeving. Das en boommarter passeerden alleen in donker, zowel op de natuurbrug als in de omgeving.

- Reebokken gebruiken de natuurbrug vaker dan reegeiten. De verhouding adulte versus juveniele dieren verschilt voor deze soort op de natuurbrug niet van die in de omgeving. Het patroon van activiteit van ree over de maanden van het jaar op de natuurbrug verschilt voor zowel bokken, geiten, adulten en juvenielen van het vertoonde activiteitenpatroon in de omgeving. Reeën passeren de natuurbrug vaker in draf of galop. Ook het gedrag dat deze doelsoort op de natuurbrug vertoont, 
verschilt van dat in de omgeving. Op de brug wordt minder stilgestaan en minder gefoerageerd. De das is de natuurbrug vooral in draf gepasseerd. Boommarter neigt naar meer sluipgang op de natuurbrug in vergelijking met de omgeving. Beide marterachtigen lieten geen grote verschillen in gedrag zien bij een vergelijking tussen natuurbrug en omgeving. De gevonden verschillen voor ree tussen natuurbrug en omgeving wat betreft tijdstip van passeren, indiceren dat deze dieren de natuurbrug ervaren als een 'andere plek dan elders'. Zij passen hun gedrag aan door onder meer later en sneller te passeren en minder te foerageren.

- Gebruik van de natuurbrug is, naast genoemde doelsoorten, ook vastgesteld voor vos, bunzing, haas en eekhoorn. Twee soorten - konijn en egel - die in lage aantallen zijn geregistreerd in de omgeving, zijn niet waargenomen op de natuurbrug. Vos en haas passeren frequent, gemiddeld een- tot tweemaal per dag. De bunzing passeert incidenteel, respectievelijk eenmaal in twee tot drie weken. De eekhoorn passeert zeer incidenteel, gemiddeld eenmaal per tien maanden. Ook voor vos, bunzing en haas is sprake van stuwing. De eekhoorn - de soort die slechts tweemaal op de natuurbrug is geregistreerd - lijkt de natuurbrug nog te mijden. Voor al deze soorten zien we de trend dat ze de natuurbrug gemiddeld later passeren dan op de referentieplekken in de omgeving. Voor bunzing is dit minder dan een halfuur, voor haas is dit bijna anderhalf uur en voor vos en eekhoorn is dit bijna twee uur. Vos en bunzing passeren vooral in donker, haas ook vaak bij daglicht. Vos passeert op de natuurbrug vaker in draf en galop dan in de omgeving. Haas passeert vaker in sprongengalop. Vossen gedragen zich op de natuurbrug anders dan in de omgeving. Ze staan relatief weinig stil, vertonen minder vaak alert gedrag en markeren relatief minder vaak. Voor haas is geen verschil in gedrag gevonden. Voor bunzing en eekhoorn is wat betreft loopwijze en gedrag geen goed vergelijk te maken.

- De natuurbrug wordt frequent gebruikt door mensen. De schatting is dat per jaar 65.000 mensen de natuurbrug passeren, oftewel gemiddeld 179 mensen per dag. Dagelijks passeren gemiddeld 136 fietsers, 38 voetgangers en 4 ruiters. De meeste mensen gebruiken de natuurbrug in het weekend. Binnen het etmaal ligt de piek in het gebruik tussen 10:00 en 12:00 uur. Circa 4 procent van het gebruik door mensen betreft een niet toegestane vorm van gebruik, i.e. per brommer/scooter, tussen zonsondergang en zonsopgang of via de voor mensen gesloten natuurzone. Illegaal gebruik is er ook door huisdieren. Honden passeren gemiddeld eenmaal per dag. Het grootste deel hiervan is niet aangelijnd. Huiskatten passeren gemiddeld tweemaal per week.

Wat is het effect van het menselijk medegebruik op het gebruik van de natuurbrug door deze zoogdieren?

- Voor ree, vos en haas is er geen effect gevonden van het menselijk medegebruik van de natuurbrug op het aantal dieren dat passeert. Voor ree is er wel een verband gevonden tussen de intensiteit van het menselijk gebruik en het tijdstip waarop de dieren passeren. Met iedere toename van 100 passerende mensen op een dag, lijken reeën het gebruik van de natuurbrug met circa een halfuur uit te stellen. Het gevonden verband is echter zwak en heeft dan ook een geringe voorspellende waarde. Voor ree is er een significant verschil tussen het gemiddelde tijdstip van passeren op drukke dagen ( $>250$ mensen) in vergelijking met rustige dagen ( $<100$ mensen). Op rustige dagen passeren de dieren gemiddeld om 18:30 uur. Op drukke dagen passeren de dieren gemiddeld bijna drie uur later.

Maken middelgrote zoogdieren gebruik van Corridor Prinses Julianalaan en de kleine faunatunnels bij de Leemzeulder en de Boissevainweg, en hoe frequent is dit gebruik?

- Voor natuurverbinding Corridor Prinses Julianalaan is gebruik door ree, vos en haas vastgesteld. In totaal zijn hier naar schatting bijna duizend passages van middelgrote zoogdieren per jaar, gemiddeld twee tot drie dieren per dag. Ree en vos passeren in min of meer vergelijkbare aantallen, gemiddeld circa negenmaal per week. Haas passeert gemiddeld minder frequent, namelijk eenmaal per week. Voor ree en vos is er sprake van stuwing: de passagefrequenties in de natuurverbinding zijn groter dan de gemiddelde passagefrequenties op de referentieplekken in de omgeving. Voor haas is er geen verschil met de omgeving vastgesteld. Das, boommarter, bunzing en eekhoorn zijn niet waargenomen in Corridor Prinses Julianalaan. De meest waarschijnlijke verklaring is dat deze soorten vooral via het naastgelegen bosgebied op Landgoed Larenberg passeren. Het raster dat hier het landgoed begrenst, is immers voor deze soorten geen absolute barrière. 
- Voor de faunatunnels onder de Leemzeulder en Boissevainweg is gebruik door de doelsoorten das en boommarter niet vastgesteld. Bij de Boissevainweg zijn wel twee andere, middelgrote zoogdieren geregistreerd: vos en egel. De vos is vijfmaal gepasseerd, de egel is eenmaal waargenomen. De huiskat is alle tunnels gepasseerd.

Zijn er verbeteringen gewenst wat de inrichting en het beheer van de natuurverbinding betreft met als doel het functioneren van de natuurbrug te optimaliseren en zo ja, welke?

- De aanbeveling is om te verkennen of de relatief brede natuurzone met menselijk medegebruik enigszins kan worden versmald ten gunste van de breedte van de natuurzone waar medegebruik niet is toegestaan.

- De aanbeveling is om het beheer van de natuurbrug te evalueren en te zien of er - ten behoeve van soorten als boommarter en eekhoorn - plaatselijk in het beheer meer ruimte kan worden gegeven aan de ontwikkeling van boomvormers, zonder dat hierbij de ontwikkeling van een zone met soortenrijke heidevegetatie in het geding komt.

- De aanbeveling is om te verkennen of het raster tussen Corridor Prinses Julianalaan en het naastgelegen Landgoed Larenberg kan worden verwijderd en het beheer van de natuurverbinding en de aangrenzende strook op het landgoed op elkaar kan worden afgestemd. De aanbeveling is om hier een heidecorridor te ontwikkelen met pleksgewijs open zand en heischraal grasland, die als verbinding kan fungeren tussen de heide op de brug en die op de Noorder- en Blaricummerheide.

- De aanbeveling is om het gebied rond de zuidelijke toeloop van de natuurbrug opnieuw in te richten, waarbij een mozaïek van open zand, heide, heischraal grasland, struweel/ruigte en gemengd bos het streefbeeld is. Bij deze herinrichting moet wel een boscorridor tot aan het brugdek over rijksweg A1 worden gehandhaafd/ontwikkeld, zodat het gebruik door sterk aan bos gebonden soorten wordt bevorderd.

- De aanbeveling is om maatregelen te nemen die het illegale gebruik van de natuurverbinding door mens en huisdier beperken, in de vorm van fysieke barrières, voorlichting en/of handhaving. Het bieden van aantrekkelijke alternatieven voor het wandelen met de hond is ook een optie. Dergelijke maatregelen zullen naar verwachting een positief effect hebben op het gebruik door middelgrote zoogdieren.

- De aanbeveling is om in circa $25 \mathrm{~m}$ (west) en $15 \mathrm{~m}$ (oost) brede zones langs de Boissevainweg inheemse bos- en struweelvegetaties te ontwikkelen, in combinaties met dood hout (stobben, takkenrillen). Deze moeten beweging en licht van de weg afschermen en dieren zowel dekking bieden als geleiden richting de tunnels.

- De aanbeveling is om het dassenraster aan de noordzijde van Corridor Prinses Julianalaan over de hele breedte van de corridor aan te leggen. Voor de gebruikers van het voet-/ruiterpad in de corridor moet dan een voorziening worden getroffen om het raster te passeren. Het advies is om dit niet in de vorm van een wildrooster, maar in de vorm van een klaphek te doen, met als voordeel dat het illegale gebruik van de corridor door fietsers wordt teruggedrongen.

\section{Adviezen voor vervolgonderzoek}

- Het advies is om het onderzoek over vijf jaar te herhalen om te onderzoeken hoe het gebruik door middelgrote zoogdieren zich heeft ontwikkeld nadat de herinrichtingsmaatregelen zijn voltooid ten noorden en zuiden van de toelopen naar de brug. In dit onderzoek zou opnieuw aandacht moeten zijn voor zowel het gebruik van de natuurbrug zelf als het gebruik van Corridor Prinses Julianalaan en tevens het naastgelegen Landgoed Larenberg.

- Het advies is om op dat moment ook het gebruik van de natuurverbinding door minder mobiele diersoorten te monitoren, zoals amfibieën, reptielen, dagvlinders, loopkevers en andere ongewervelden. Daarnaast is het advies om het gebruik door vleermuizen te onderzoeken.

- Het advies is om de kleine faunatunnels opnieuw te monitoren na aanpassing van het raster langs de Leemzeulder en ontwikkeling van zones met opgaande beplanting en dood hout (stobben, takkenrillen) langs de Boissevainweg.

- Het advies is om de huidige dataset te gebruiken om voor ree een schatting te maken van het aantal individuen dat de natuurbrug gebruikt. 


\section{$1 \quad$ Inleiding}

\subsection{Achtergrond}

Op 6 februari 2015 is Natuurbrug Laarderhoogt geopend. Deze natuurbrug ligt ten zuidoosten van Laren en overspant rijksweg A1 en de langs deze snelweg gelegen parallelweg (zuid) en fietspad (noord), en de gemeentelijke weg Naarderstraat met de daarnaast gelegen fietspaden. Natuurbrug Laarderhoogt heeft als doel om de natuurgebieden in het noordelijk deel van het Gooi te verbinden met die in het zuidelijk deel en op de Utrechtse Heuvelrug. Om dit te bereiken, sluit de natuurbrug aan de zuidkant aan op het natuurgebied Bussummerheide/Westerheide. Aan de noordkant sluit de natuurbrug aan op Landgoed Larenberg, in particulier bezit en beheer, en een smalle ecologische verbindingszone richting de Noorderheide en Blaricummerheide, in eigendom en beheer bij het Goois Natuurreservaat (Figuur 1). De natuurverbinding is bedoeld voor diersoorten van bossen en heide op droge zandgronden. De natuurbrug heeft ook een verbindende functie voor mensen. Zowel wandelaars, fietsers als ruiters kunnen gebruikmaken van de natuurbrug. Hiervoor zijn een gecombineerd fiets-/voetpad en een ruiterpad aangelegd.

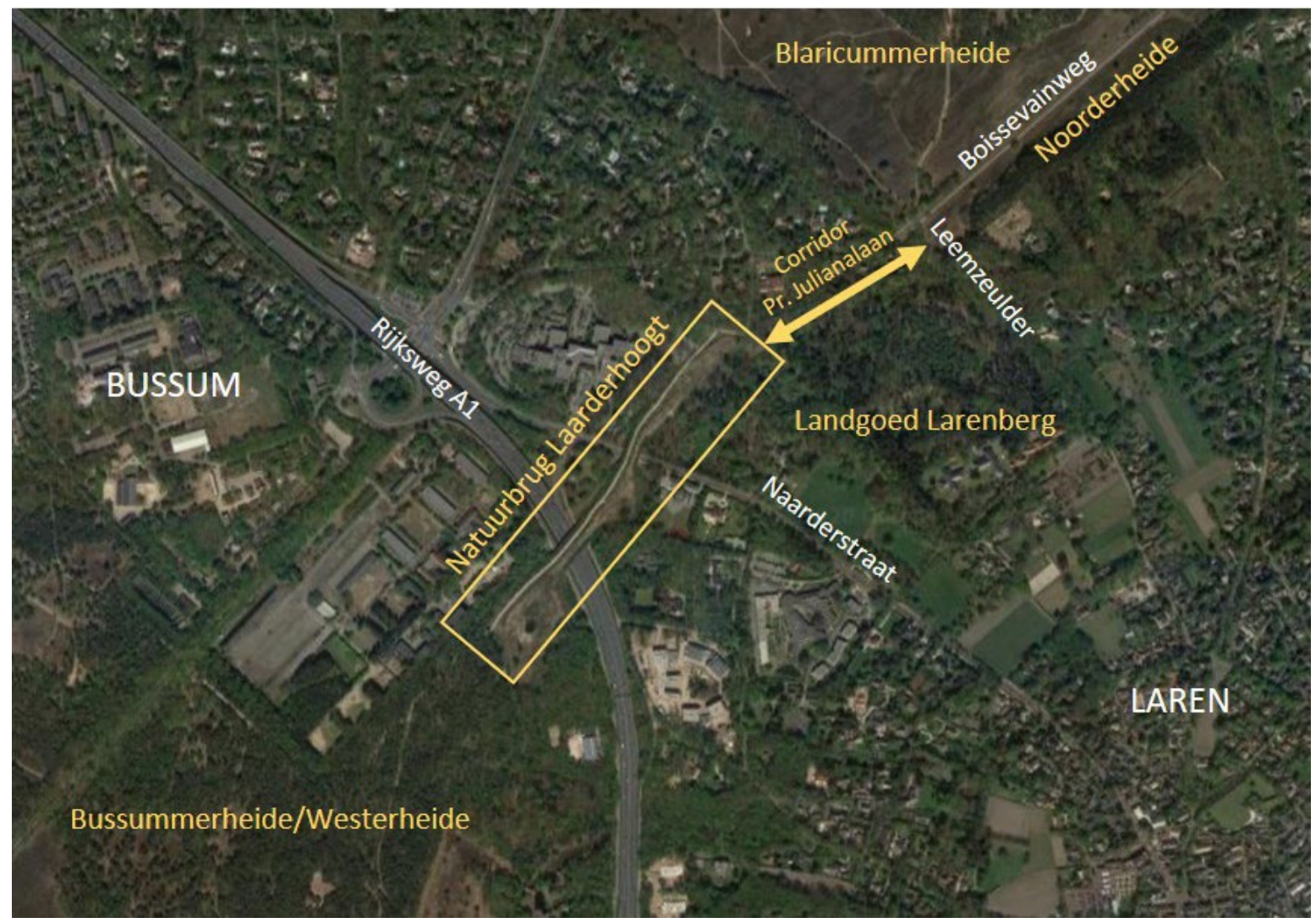

Figuur 1 Ligging van natuurverbinding Laarderhoogt.

Natuurbrug Laarderhoogt ligt, in tegenstelling tot veel andere ecoducten, in een sterk verstedelijkt gebied. De ontwerpruimte voor zowel de natuurbrug als de noordelijke en zuidelijke toeloop was hierdoor beperkt. Het ontwerp van de natuurverbinding wijkt in sommige opzichten dan ook af van natuurverbindingen die elders, op plekken met meer ruimte, zijn gerealiseerd. Wat betekent dit voor de functionaliteit van de natuurbrug? Maken de dieren waarvoor de brug bedoeld is er wel gebruik van? En als ze dat doen, is dit dan incidenteel of passeren ze de natuurbrug met regelmaat? 
In Nederland zijn inmiddels meer dan zeventig natuurbruggen gebouwd of in aanbouw. Slechts een klein deel hiervan (tien natuurbruggen) is opengesteld voor medegebruik door mensen. Vooralsnog is weinig bekend over hoe dit menselijk medegebruik het gebruik door fauna beïnvloedt. Onderzoek op Natuurbrug Zanderij Crailoo heeft laten zien dat de passagefrequentie van enkele middelgrote zoogdieren (ree, vos, haas en konijn) op dagen dat veel mensen gebruikmaakten van de brug niet significant verschilde van die op dagen dat er weinig mensen passeerden (Van der Grift et al., 2010). Wel is geconstateerd dat deze diersoorten op drukke dagen pas enkele uren later op de natuurbrug verschenen. Deze soorten lijken het moment waarop ze gebruikmaken van de verbinding dus aan te passen aan de omvang van het gebruik door mensen. Een vergelijkbare studie is in 2014 gestart op de natuurbruggen Zwaluwenberg en Hoorneboeg, net ten zuiden van Hilversum. ${ }^{1}$ De resultaten van die studie worden echter pas in 2021 verwacht. Op de overige natuurbruggen in ons land met menselijk medegebruik is een dergelijk onderzoek vooralsnog niet uitgevoerd. Ook heeft buitenlands onderzoek tot dusverre maar beperkt kennis over de effecten van menselijk medegebruik gebracht. Dit is vooral een gevolg van een verschil in de omvang van het medegebruik. In buitenlandse studies gaat het veelal om incidentele passages van mensen, terwijl het in Nederland al snel vele tienduizenden passages van mensen per jaar betreft (zie o.a. Mata et al., 2005). Daarnaast betreft het in buitenlandse studies vaak diersoorten die hier niet voorkomen. Het gedeeltelijk openstellen van Natuurbrug Laarderhoogt voor mensen roept dus een aantal vragen op. Hoe beïnvloedt het menselijk medegebruik van de natuurbrug het gebruik door de dieren? Passeren de dieren minder vaak op dagen dat er veel mensen zijn gepasseerd? Of zijn er effecten te zien op het moment of de manier waarop de dieren de natuurbrug passeren?

Met deze achtergrond was het de wens van de provincie Noord-Holland en haar partners - het Goois Natuurreservaat, Rijkswaterstaat en de gemeenten Laren en Blaricum - om het functioneren van Natuurbrug Laarderhoogt te laten onderzoeken. Met daarbij aandacht voor het gebruik van de natuurbrug door zowel dieren als mensen en de wijze waarop deze elkaar eventueel beïnvloeden. Enerzijds is dit dus een evaluatie van het functioneren van deze specifieke natuurverbinding met haar bijzondere kenmerken, anderzijds biedt het de kans om meer kennis te verwerven over de effecten van het openstellen van natuurbruggen voor medegebruik door mensen. Aangezien de maatschappelijke acceptatie van natuurbruggen, zeker in dichtbevolkte gebieden, meestal toeneemt als menselijk medegebruik wordt toegestaan, achten de provincie Noord-Holland en haar partners kennisontwikkeling van de effecten van menselijk medegebruik van groot belang.

\subsection{Doel van het onderzoek}

Het doel van het onderzoek is drieledig:

- Een eerste doel is om vast te stellen of de natuurbrug goed functioneert voor de zoogdiersoorten die als doelsoort zijn aangewezen voor de natuurverbinding.

- Een tweede doel is om meer inzicht te verkrijgen in de effecten van het menselijk medegebruik op het gebruik van de natuurbrug door deze zoogdieren.

- Een derde doel is om te verkennen of er aanpassingen in de inrichting en het beheer van de natuurbrug gewenst zijn om het gebruik ervan door deze zoogdieren te optimaliseren.

Het onderzoek richt zich dus uitsluitend op zoogdieren, specifiek de soorten die als doelsoort voor de natuurverbinding zijn aangewezen: ree, das en boommarter. Tijdens de monitoring van deze soorten is echter ook het gebruik door andere middelgrote zoogdieren vastgesteld. Deze soorten zijn dan ook betrokken in het onderzoek. De toetsing van het functioneren van de natuurbrug is echter gebaseerd op het gebruik door de drie doelsoorten.

Het onderzoek richt zich primair op het functioneren van de natuurbrug. Daarnaast gaat de aandacht ook uit naar het gebruik van (1) de ecologische verbindingszone aan de noordzijde van de natuurbrug - in het navolgende Corridor Prinses Julianalaan genoemd -, (2) twee kleine faunapassages onder de Leemzeulder - een gemeentelijke weg - die deze verbindingszone met de Noorderheide moeten verbinden en (3) zes kleine faunapassages onder de Boissevainweg - een provinciale weg - die de

1 Zie: https://www.noord-holland.nl/Onderwerpen/Natuur/Natuurbeheer/Monitoring_van_natuurverbindingen 
Noorderheide met de Blaricummerheide moeten verbinden (zie ook Figuur 1). Al deze maatregelen samen, dus van Westerheide tot aan Blaricummerheide, noemen we Natuurverbinding Laarderhoogt.

\subsection{Onderzoeksvragen}

Om deze doelen te bereiken, richten we ons in het onderzoek op de volgende vragen:

1. Maken middelgrote zoogdieren gebruik van de natuurbrug, hoe frequent en op welke wijze doen zij dit en wordt hiermee aan vooraf gestelde doelen voor het gebruik van de natuurbrug voldaan?

2. Wat is het effect van het menselijk medegebruik op het gebruik van de natuurbrug door deze zoogdieren?

3. Maken middelgrote zoogdieren gebruik van Corridor Prinses Julianalaan en de kleine faunatunnels bij de Leemzeulder en de Boissevainweg en zo ja, hoe frequent is dit gebruik?

4. Zijn er verbeteringen gewenst wat de inrichting en het beheer van de natuurverbinding betreft met als doel het functioneren van de natuurbrug te optimaliseren en zo ja, welke?

\subsection{Leeswijzer}

In hoofdstuk 2 zijn het doel en de doelsoorten voor Natuurverbinding Laarderhoogt beschreven. Tevens geeft dit hoofdstuk een korte karakteristiek van de natuurbrug, de natuurverbinding Corridor Prinses Julianalaan en de faunamaatregelen bij de Leemzeulder en Boissevainweg. Hoofdstuk 3 beschrijft het in dit onderzoek gebruikte toetsingskader en de gebruikte onderzoeksmethoden. Daarbij gaat de aandacht uit naar methoden voor zowel het verzamelen, verwerken en analyseren van de gegevens. Hoofdstuk 4 presenteert het gebruik van de natuurbrug door middelgrote zoogdieren. Het laat zien welke soorten de natuurbrug gebruiken, hoe frequent ze dit doen en op welke manier ze passeren. In dit hoofdstuk wordt dit gebruik beoordeeld op basis van het in het voorgaande hoofdstuk gepresenteerde toetsingskader. In hoofdstuk 5 is het gebruik van de natuurbrug door mens en huisdier beschreven. Zowel wat betreft omvang als aard van het gebruik. Hierbij is ook aandacht voor het illegale gebruik van de natuurbrug. Hoofdstuk 6 richt zich op de vraag of het medegebruik door mensen effect heeft op het gebruik door middelgrote zoogdieren. Hoofdstuk 7 en 8 presenteren vervolgens de bevindingen van de monitoring van Corridor Prinses Julianalaan respectievelijk de kleine faunatunnels onder de Leemzeulder en Boissevainweg. In hoofdstuk 9 zijn de conclusies van het onderzoek gepresenteerd. Ten slotte is in hoofdstuk 10 een aantal aanbevelingen uitgewerkt, voor inrichting en beheer van de natuurverbinding en voor eventueel vervolgonderzoek. 


\section{$2 \quad$ Natuurverbinding Laarderhoogt}

\section{$2.1 \quad$ Inleiding}

In dit hoofdstuk beschrijven we kort het doel van de natuurverbinding en de doelsoorten die hiervoor zijn aangewezen. Tevens beschrijven we de kenmerken van de natuurbrug, de natuurverbinding Corridor Prinses Julianalaan en de kleine faunatunnels bij de Leemzeulder en Boissevainweg. De aandacht gaat hierbij vooral uit naar afmetingen, inrichting, geleiding en, in geval van de natuurbrug en corridor, de aard van het gebruik door mensen.

\subsection{Doel Natuurverbinding Laarderhoogt}

Het doel van de natuurverbinding is het versterken van de ecologische en recreatieve samenhang tussen de bos- en heidegebieden van het Gooi (Veen en Brandjes, 2000; Goois Natuurreservaat et al., 2003; Goois Natuurreservaat, 2009). Of, zoals het Meerjarenprogramma Ontsnippering (MJPO) het stelt, moet de natuurbrug 'het noordelijk en zuidelijk deel van het Gooi weer aan elkaar knopen' (Ministerie van V\&W et al., 2004). Concreet betekent dit dat de natuurverbinding de uitwisseling van mens en dier mogelijk moet maken tussen de natuurgebieden ten zuiden (o.a. Bussummerheide, Westerheide, Zuiderheide) en noorden (o.a. Landgoed Larenberg, Noorderheide, Blaricummerheide, Tafelbergheide) van de infrastructurele barrière die de A1 en Naarderstraat vormen. Deze natuurgebieden maken alle deel uit van het Nationale Natuurnetwerk. De ambitie is om met het herstellen van de ruimtelijke samenhang in dit deel van het natuurnetwerk de overlevingskansen voor plant- en diersoorten te vergroten (Van der Grift et al., 2003). Het streven was dan ook gericht op het realiseren van een verbinding op ecosysteemniveau. Dit betekent dat de natuurverbinding voldoende ruimte zou moeten bieden om alle gewenste biotooptypen van bos en heide, met alle daarbinnen levende plant- en diersoorten, duurzaam een plek te geven en ruimte te bieden aan ecosysteemprocessen (zie ook Van der Grift, 2006).

\subsection{Doelsoorten}

Voor Natuurverbinding Laarderhoogt zijn zeven doelsoorten aangewezen die drie landschapstypen representeren (Bergsma-Eijsackers, 2006):

\begin{tabular}{ll} 
Landschapstype & Doelsoort \\
\hline Bos & Boommarter, Hazelworm \\
\hline Heide & Zandhagedis, Heideblauwtje, Groene zandloopkever \\
\hline Overgangsgebied & Das, Ree \\
\hline
\end{tabular}

Deze doelsoorten moeten worden gezien als paraplu- of indicatorsoorten: als de natuurverbinding functioneel is voor deze soorten, is de verwachting dat de natuurverbinding ook zal werken voor veel andere soorten die in het gebied voorkomen.

\subsection{Kenmerken Natuurbrug Laarderhoogt}

\section{Afmetingen}

Natuurbrug Laarderhoogt bestaat uit twee in het verlengde van elkaar gelegen ecoducten en een circa 1,5 ha groot tussengebied (Figuur 2). Het zuidelijke ecoduct overbrugt rijksweg A1. Dit ecoduct is 
circa $75 \mathrm{~m}$ lang en $40 \mathrm{~m}$ breed. Het tweede ecoduct overbrugt de Naarderstraat. Dit ecoduct is circa $25 \mathrm{~m}$ lang en $30 \mathrm{~m}$ breed. De afstand tussen de twee ecoducten is circa $150 \mathrm{~m}$. De toelopen - zowel aan de noord- als zuidzijde - zijn circa $150 \mathrm{~m}$ lang. De natuurbrug in zijn geheel, inclusief toelopen en tussengebied, heeft hiermee een lengte van circa $500 \mathrm{~m}$.

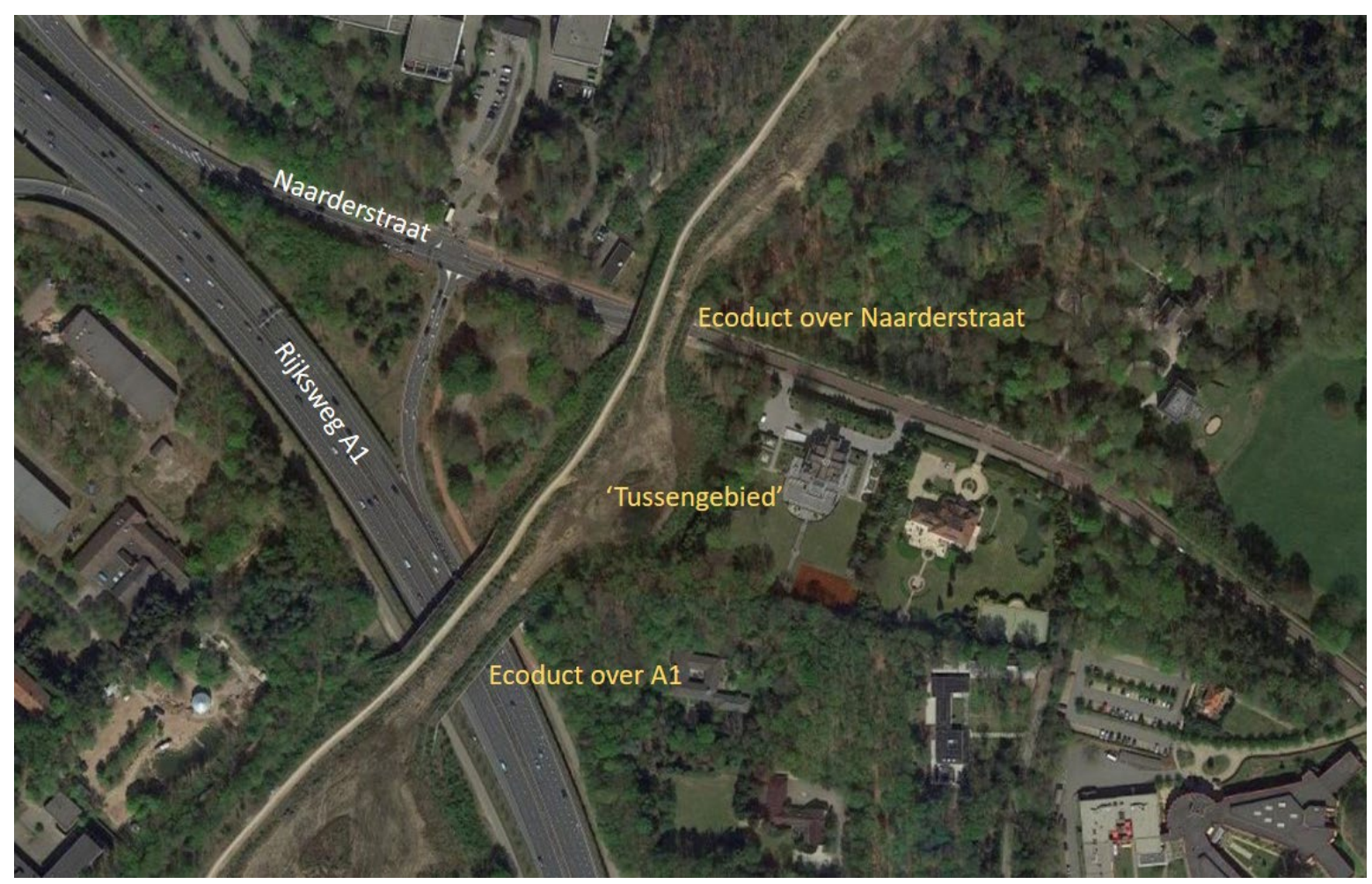

Figuur 2 Natuurbrug Laarderhoogt met de ecoducten over respectievelijk rijksweg A1 en de Naarderstraat en het 'tussengebied'.

Figuur 3 geeft een schematische dwarsdoorsnede van het ecoduct over de Naarderstraat. Het brugdek is $30 \mathrm{~m}$ breed. De functionele breedte - de ruimte tussen de aan weerszijden op schanskorven geplaatste rasters - is 22,5 m. Hierbinnen zijn twee zones te onderscheiden: (1) een zone waar medegebruik door mensen niet is toegestaan en (2) een zone waar medegebruik door mensen wel is toegestaan. De zone waar medegebruik door mensen niet is toegestaan - in het navolgende 'natuurzone zonder menselijk medegebruik' genoemd - is circa $15 \mathrm{~m}$ breed. De zone waar medegebruik door mensen wel is toegestaan - in het navolgende 'natuurzone met menselijk medegebruik' genoemd - is circa 7,5 m breed. Een circa 1,10 m hoog raster vormt de grens tussen beide zones.

\section{Inrichting}

De natuurzone zonder menselijk medegebruik ligt aan de oostkant op het brugdek (Figuur 4) en bestaat van oost naar west uit: (a) struweel met boomvormers, (b) heide en grazige vegetatie, (c) een stobbenwal en (d) struweel met droge ruigte. De natuurzone met menselijk medegebruik ligt aan de westkant op het brugdek en bestaat van oost naar west uit: (a) een grazige berm, (b) een ruiterpad, (c) een gecombineerd fiets-/voetpad en (d) struweel. Het fiets-/voetpad is half verhard, het ruiterpad is onverhard (Figuur 5).

Op de toelopen naar de natuurbrug en in het tussengebied is een mozaïek van bos- en heidebiotoop het streven, met lokaal ruimte voor open zandige plekken, heischraal grasland, droge ruigte en struweel. Op beide toelopen en in het tussengebied ligt een poel die leefgebied biedt aan (semi-) aquatische diersoorten, zoals amfibieën en libellen. De poelen zijn daarnaast drinkplaatsen voor zoogdieren.

Sinds de openstelling van de natuurbrug in 2015 heeft de vegetatie zich zowel op de ecoducten, op de toelopen als in het tussengebied, snel ontwikkeld. Bijlage 1 bevat een korte beschrijving van de aanwezige vegetatietypen en een lijst met kenmerkende plantensoorten. 


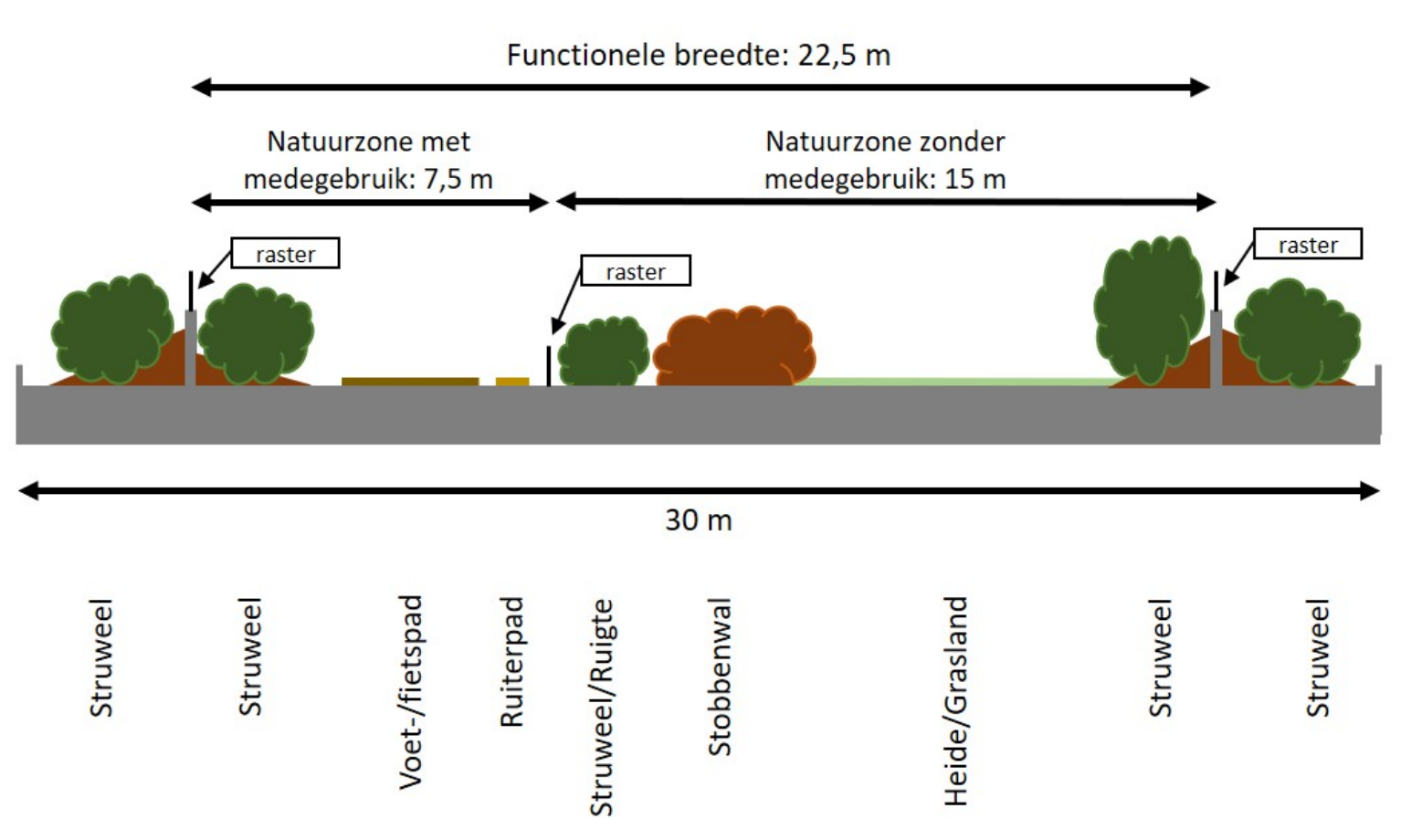

Figuur 3 Dwarsdoorsnede van het ecoduct over de Naarderstraat.

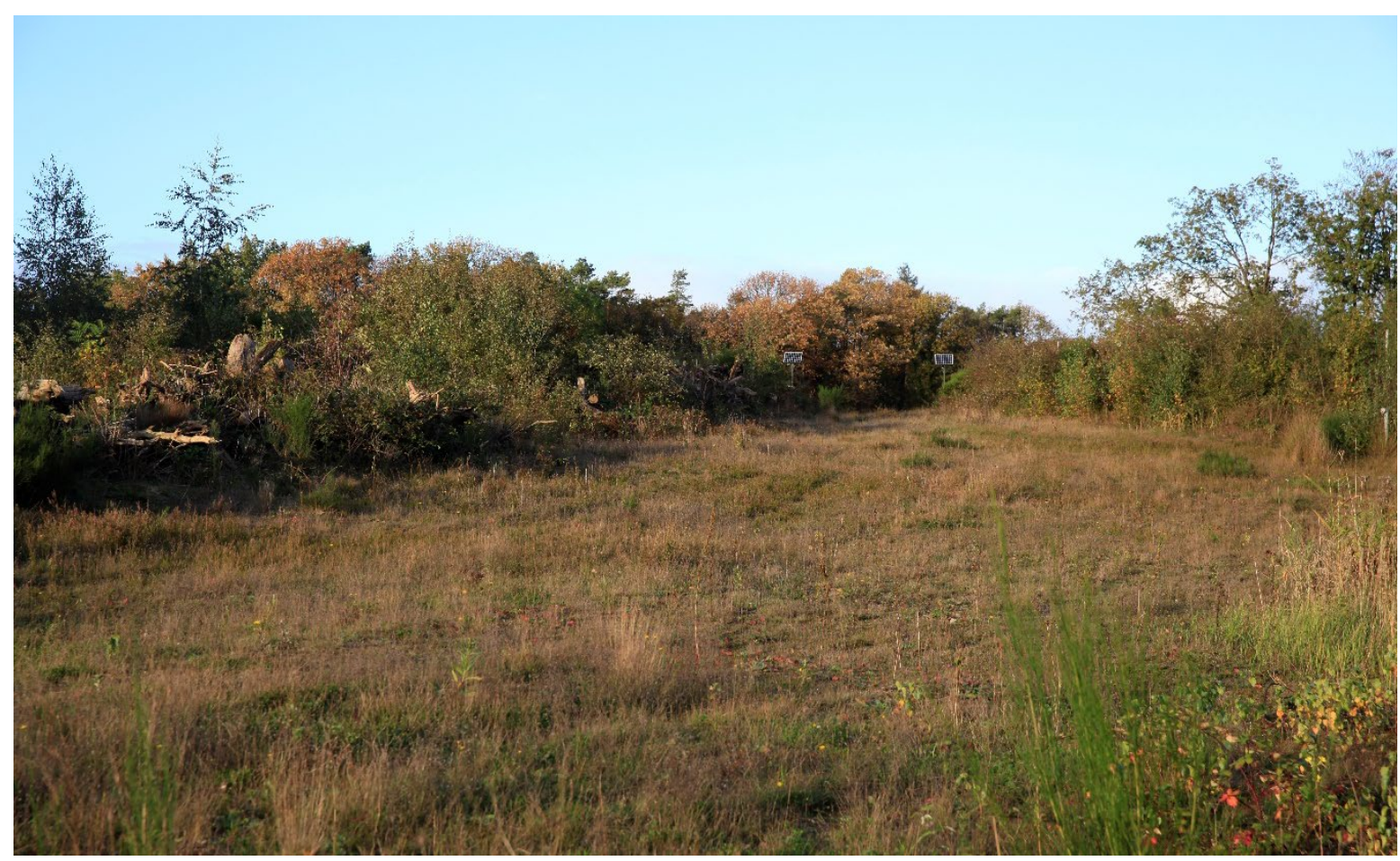

Figuur 4 Het ecoduct over de Naarderstraat, gezien vanuit het zuiden. Met op de voorgrond de zone met grazige vegetaties en links de stobbenwal.

De inrichting van het ecoduct over rijksweg A1 is identiek aan die over de Naarderstraat, waarbij alleen de maatvoering verschilt. De functionele breedte van dit ecoduct is $30 \mathrm{~m}$. De natuurzone met menselijk medegebruik en natuurzone zonder menselijk medegebruik zijn hier respectievelijk 10 en 20 m breed. 

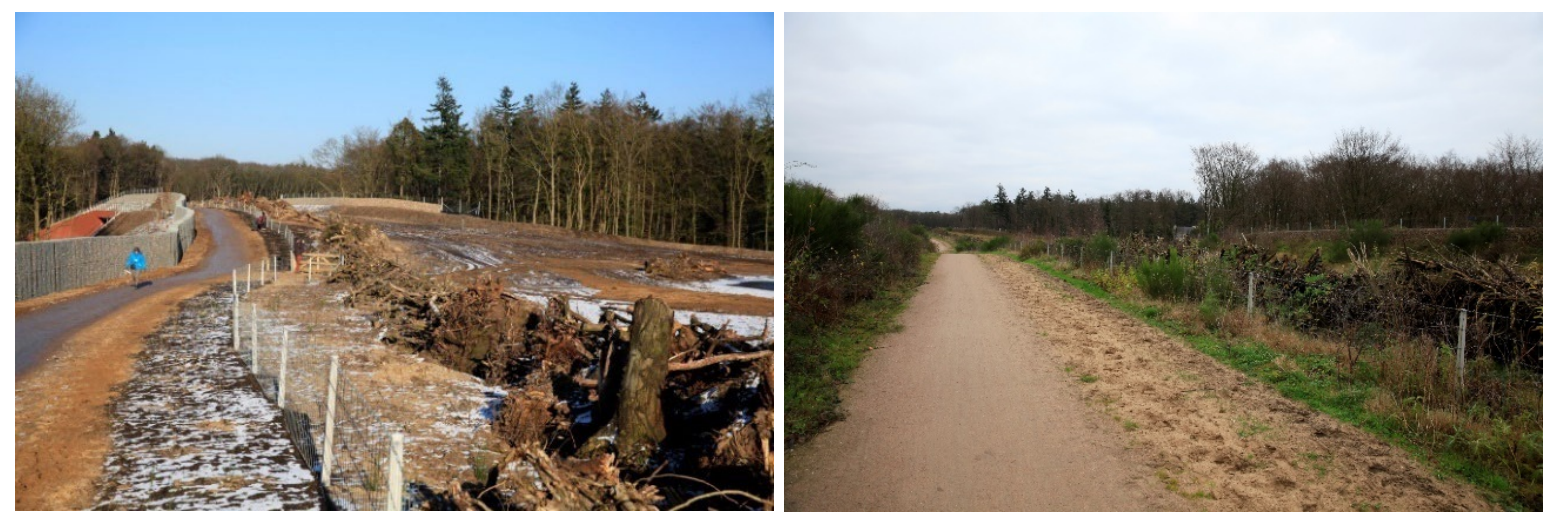

Figuur 5 Links: Het tussengebied (voorgrond) en ecoduct over de Naarderstraat (achtergrond) kort na de openstelling van de natuurbrug in februari 2015, met links het fiets-/voetpad en ruiterpad en rechts de natuurzone zonder menselijk medegebruik, van elkaar gescheiden door een raster. Rechts: De natuurzone met menselijk medegebruik twee jaar na de openstelling (december 2017).

\section{Voorzieningen voor mensen}

De natuurbrug is voor fietsers, voetgangers en ruiters opengesteld van zonsopgang tot zonsondergang. De natuurbrug is niet opengesteld voor bromfietsen en motorvoertuigen. Ook honden - aangelijnd of loslopend - zijn niet toegestaan (Figuur 6). Aan de zuidkant van de natuurbrug sluiten de paden aan op de fiets-, voet- en ruiterpaden van de Westerheide. Aan de noordkant van de natuurbrug worden fietsers richting de Prins Hendriklaan geleid. Het faunakerende raster wordt hierbij gepasseerd via een wildrooster (Figuur 7). Voetgangers kunnen hier (a) afbuigen naar een voetpad achter het ziekenhuis, via een klaphek (Figuur 7), (b) het fietspad volgen richting de Prins Hendriklaan of (c) afbuigen naar het voetpad in Corridor Prinses Julianalaan. Alleen dit laatste pad is een optie voor ruiters.
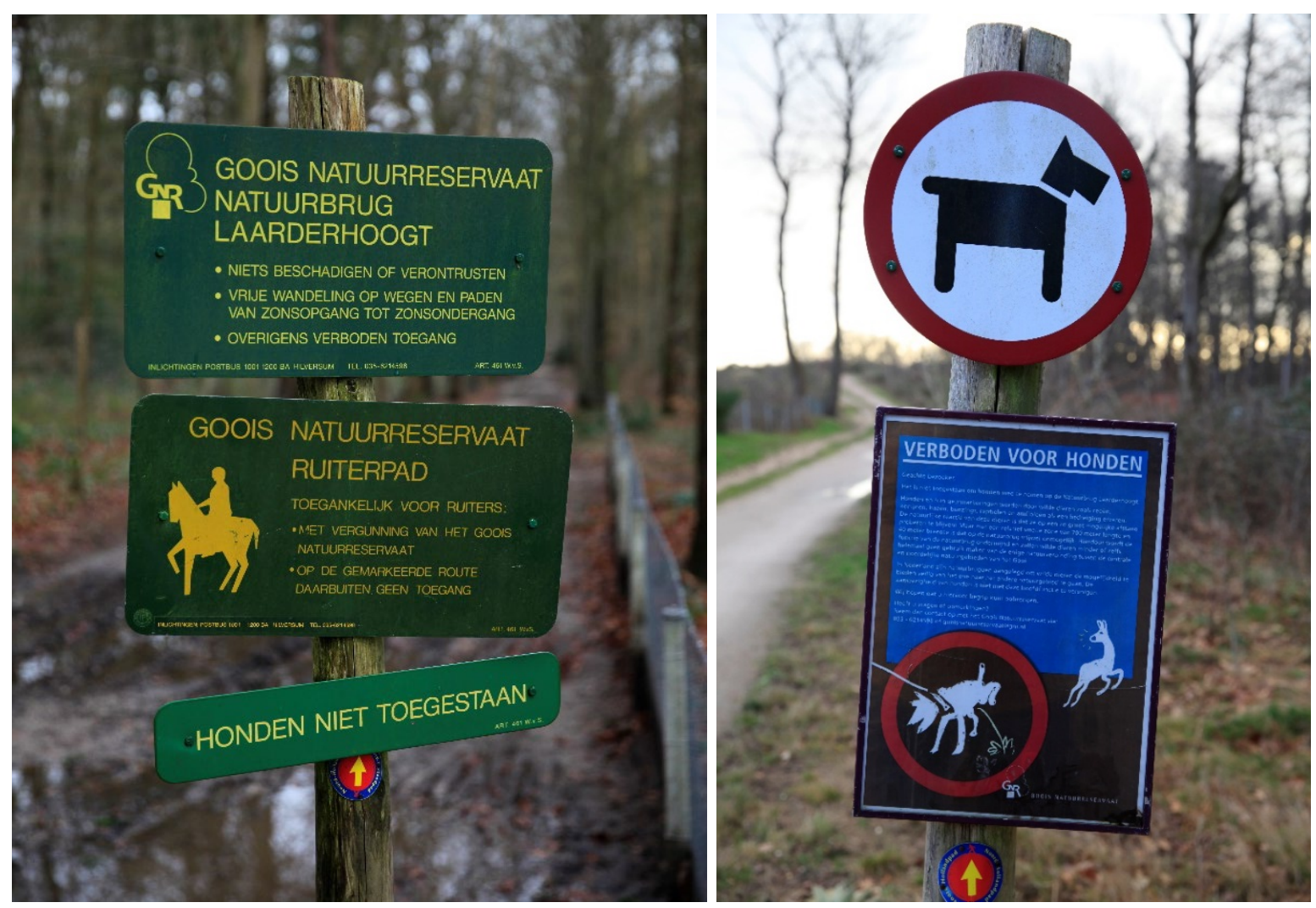

Figuur 6 Restricties die aan het gebruik van de natuurbrug door mensen en honden worden gesteld. Een informatiebord (rechts) vertelt bezoekers ook waarom honden niet zijn toegestaan: "Honden en hun geurmarkeringen worden door wilde dieren [...] als een bedreiging ervaren." 

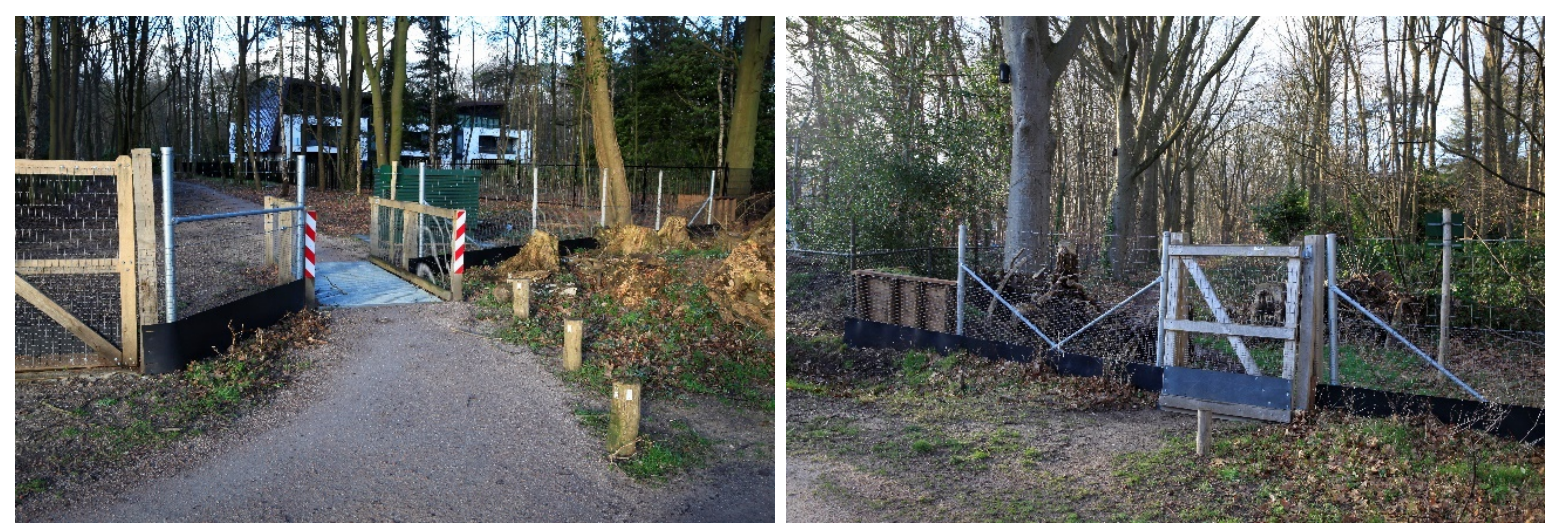

Figuur $7 \quad$ Het fiets-/voetpad dat het faunakerende raster via een wildrooster passeert richting Prins Hendriklaan (links) en het klaphek dat de natuurbrug verbindt met het voetpad achter het ziekenhuis (rechts).

\section{Geleiding}

Fauna wordt naar en over de natuurbrug geleid met behulp van schanskorven en rasters (Figuur 8). Aan de westzijde van zowel de twee ecoducten als het tussengebied is een circa 2,5 m hoge muur van schanskorven aangelegd. Op beide ecoducten is hiertegen een aarden berm aangebracht tot circa 1,5 $\mathrm{m}$ hoogte. Om te voorkomen dat dieren over de schanskorven springen zijn hier boven op de schanskorven 0,5 m hoge faunakerende rasters geplaatst. De schanskorven sluiten aan op bestaande rasters van naastgelegen terreinen of nieuw geplaatste faunakerende rasters. Deze faunakerende rasters zijn combinatierasters die bestaan uit een amfibiescherm $(0,4 \mathrm{~m}$ hoog), een dassenraster ( $1,1 \mathrm{~m}$ hoog) en een grofwildraster ( $2 \mathrm{~m}$ hoog). Aan de noordkant van de natuurbrug zijn twee insprongen in het raster aangelegd. Deze stellen dieren in staat om het raster te passeren als ze onverhoopt aan de verkeerde kant van het raster terecht zijn gekomen.
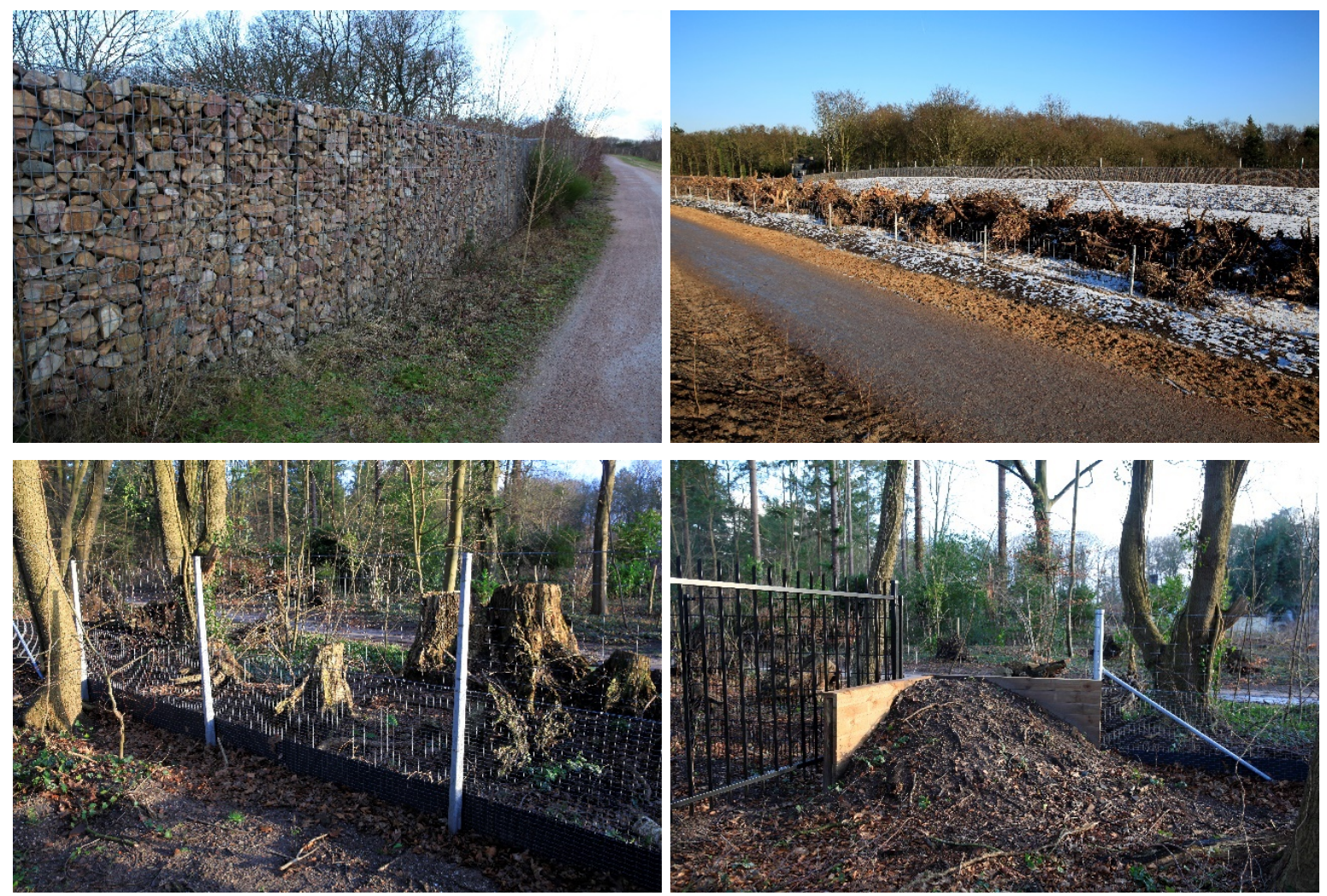

Figur 8 Hoge muur van schanskorven aan de westzijde van de natuurbrug (linksboven), schanskorven met boven op een raster en een aarden berm op het ecoduct over de A1 (rechtsboven), faunakerend combinatieraster aan de noordzijde van de natuurbrug (linksonder) en een insprong nabij Corridor Prinses Julianalaan die dieren in staat stelt het raster te passeren (rechtsonder). 


\subsection{Kenmerken Corridor Prinses Julianalaan}

Corridor Prinses Julianalaan is een smalle natuurverbinding die de toeloop van de natuurbrug verbindt met de Noorderheide (zie ook Figuur 1). De corridor is circa $350 \mathrm{~m}$ lang en 20-25 m breed. Aan de oostzijde wordt de corridor begrensd door het Landgoed Larenberg. Dit landgoed is in particulier eigendom en bestaat voor het grootste deel uit gemengd bos. Het landgoed is aangewezen als kerngebied in het Nationale Natuurnetwerk (NNN). De corridor en het landgoed zijn van elkaar gescheiden door een $2 \mathrm{~m}$ hoog raster. Dit raster is grofmazig en niet ingegraven, wat betekent dat het voor kleine en middelgrote zoogdieren geen absolute barrière is. Voor reeën is het wel een obstakel, maar ook voor deze dieren is het raster op sommige plaatsen te passeren. Aan de westzijde grenst de corridor aan particuliere tuinen. De omheiningen van deze kavels verschillen en bestaan voor een deel uit faunakerende rasters. Ook hier is voor de meeste zoogdieren echter geen sprake van een absolute barrière. Naast een gecombineerd voet-/ruiterpad, met een breedte van circa $5 \mathrm{~m}$, bestaat de verbinding uit struweel en loofbos (Figuur 9). De natuurverbinding is nog in ontwikkeling. Het streven is om op termijn middels gericht beheer pleksgewijs meer ruimte te bieden aan heidevegetatie (pers. com. P. Hulzink, Goois Natuurreservaat).
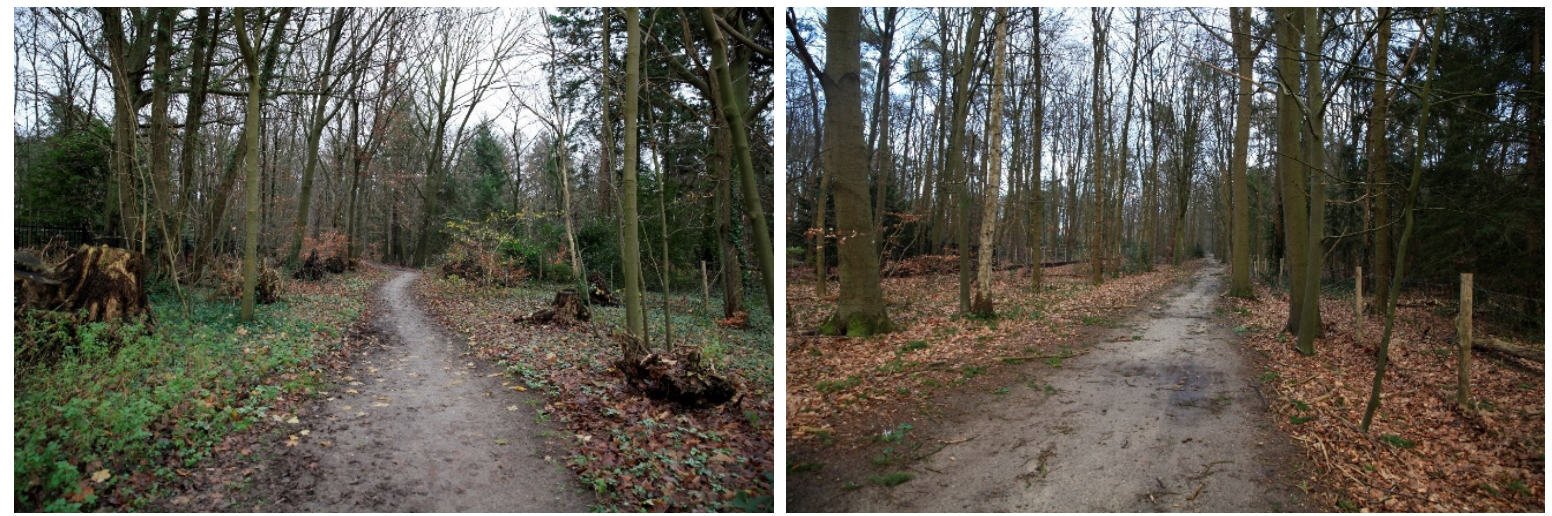

Figuur 9 Corridor Prinses Julianalaan met bos, struweel en een gecombineerd voet-/ruiterpad.

\subsection{Kenmerken kleine faunatunnels}

De Leemzeulder, een gemeentelijk klinkerweg, moet door de dieren worden gepasseerd om vanuit Corridor Prinses Julianalaan de Noorderheide te bereiken. De Boissevainweg (N526), een provinciale weg, moet vervolgens worden gepasseerd om vanaf de Noorderheide de Blaricummerheide te bereiken (Figuur 10).
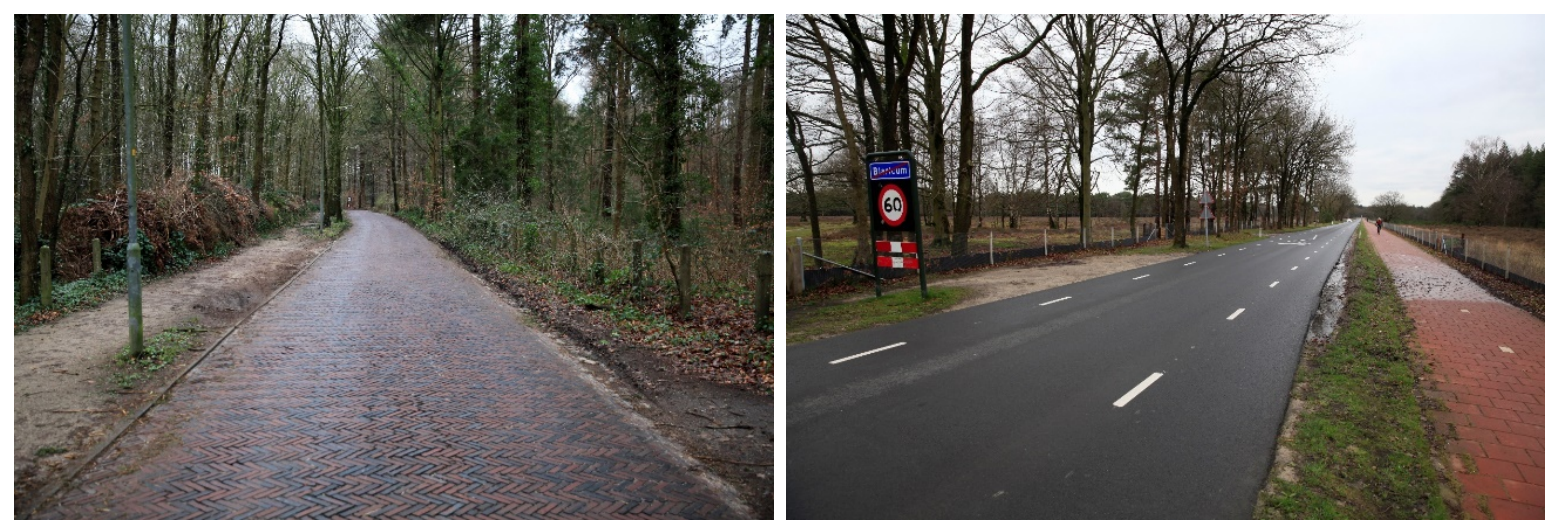

Figuur 10 De Leemzeulder (links) en Boissevainweg (rechts). 


\section{Leemzeulder}

Het betreft een lokale weg die de Boissevainweg verbindt met Laren. De weg is circa $5 \mathrm{~m}$ breed en bestaat uit één rijbaan. De weg wordt aan de noordzijde begrensd door de Noorderheide, landgoed Klein Raboes en het terrein van Scouting Raboes. Aan de zuidzijde ligt een particulier perceel, Corridor Prinses Julianalaan, en Landgoed Larenberg. Ter hoogte van de Noorderheide ligt er een voetpad direct naast de weg. De toegestane rijsnelheid is hier $50 \mathrm{~km} / \mathrm{uur}$. De verkeersintensiteit is onbekend, maar wordt op basis van eigen tellingen geschat op $<1000$ voertuigen per weekdag.

In januari 2019 zijn er in deze weg twee faunatunnels aangelegd en zijn er geleidende rasters geplaatst. De tunnels passeren zowel de Leemzeulder als het naastgelegen voetpad. Het betreft een amfibietunnel en een dassentunnel (Figuur 11). De amfibietunnel is van beton, rechthoekig $(0,5 \mathrm{~m}$ breed, 0,57 m hoog) en circa $8 \mathrm{~m}$ lang (ACO Pro klimaatportaal KP 1000-700). De bovenzijde van de tunnel ligt in het wegdek en bevat openingen. De dassentunnel is een ronde, stalen buis, eveneens $8 \mathrm{~m}$ lang, met een diameter van 0,5 m.

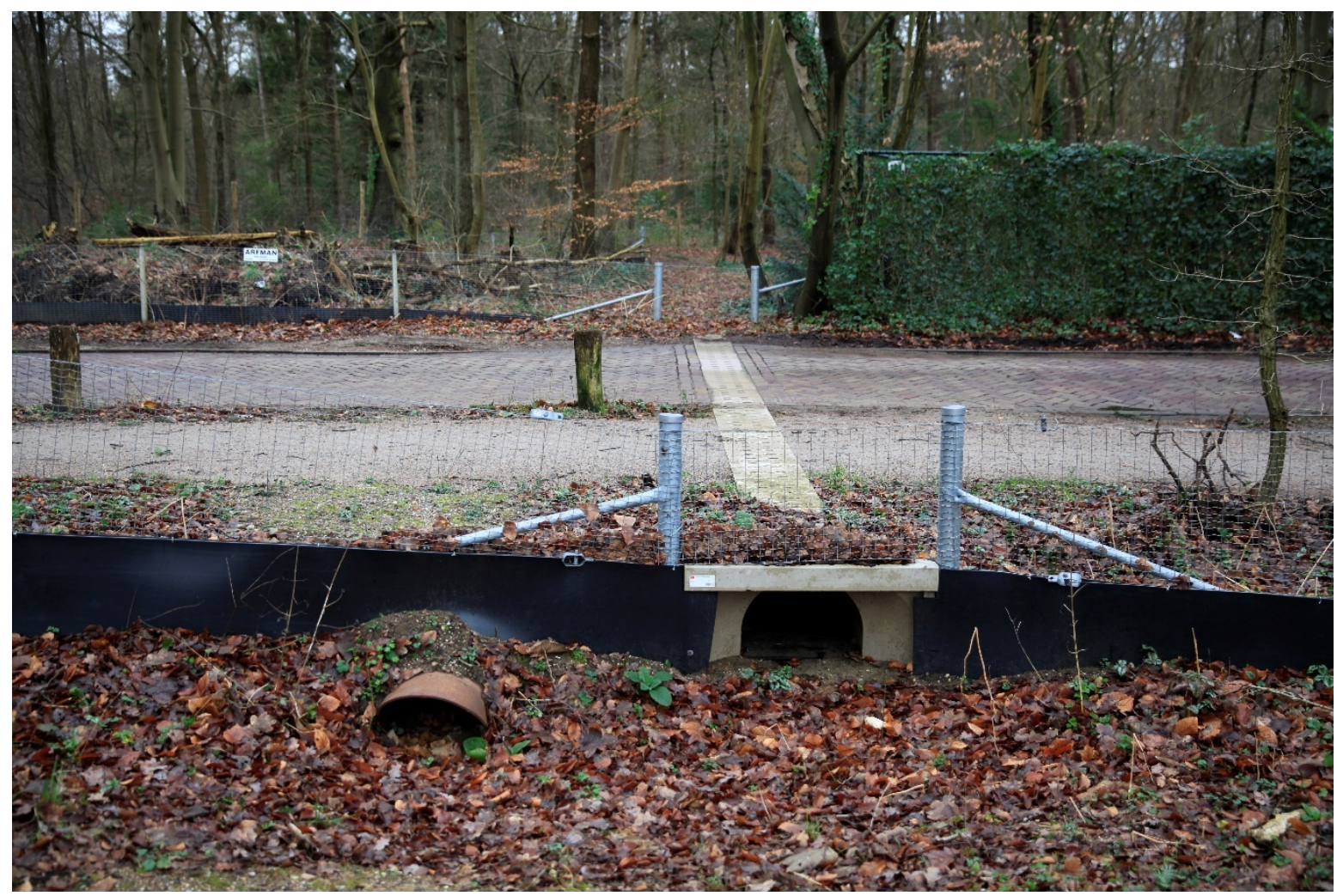

Figuur 11 De twee faunatunnels onder de Leemzeulder, met op de achtergrond de noordzijde van Corridor Prinses Julianalaan.

De rasters zijn circa 1,1 $\mathrm{m}$ hoog, ingegraven en bevatten een circa 0,4 $\mathrm{m}$ hoog amfibiescherm aan de onderzijde. Aan de zuidzijde van de Leemzeulder is dit raster circa $10 \mathrm{~m}$ lang. Aan de westzijde sluit het aan op de afrastering van een particulier perceel. Aan de oostzijde buigt het raster af naar het zuiden, waar het nog circa $20 \mathrm{~m}$ langs het voet-/ruiterpad in de corridor is voortgezet (Figuur 12). Aan de noordzijde van de Leemzeulder is het raster circa $75 \mathrm{~m}$ lang (Figuur 12). Aan de westzijde sluit het aan op de faunarasters langs de Boissevainweg. Aan de oostzijde sluit het aan op het faunaraster dat langs de oostgrens van de Noorderheide staat. 

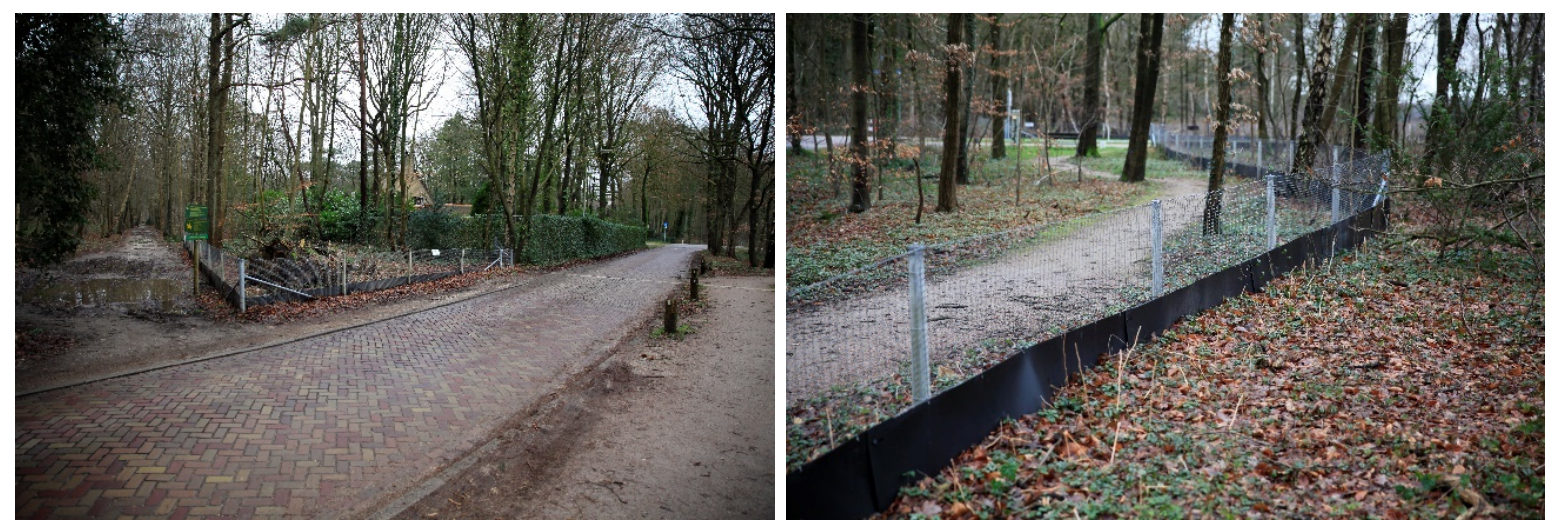

Figuur 12 Het geleidende faunaraster langs de zuid- (links) en noordzijde (rechts) van de Leemzeulder.

\section{Boissevainweg}

Het betreft een gebiedsontsluitingsweg tussen de aansluiting op rijksweg A1 en Blaricum. De weg is circa $6,5 \mathrm{~m}$ breed en bestaat uit één rijbaan met twee rijstroken. Aan de oostzijde van de weg ligt een fietspad, circa $3 \mathrm{~m}$ breed, waarop in twee richtingen mag worden gereden. De weg doorsnijdt over een lengte van circa $1 \mathrm{~km}$ het heidegebied van de Blaricummerheide/Noorderheide. De toegestane rijsnelheid is hier $60 \mathrm{~km} / \mathrm{uur}$. De verkeersintensiteit is gemiddeld 5.675 voertuigen per weekdag (bron: Provincie Noord-Holland; cijfers 2019).

Bij de Boissevainweg is in 2005 op drie plaatsen een kleine faunatunnel met geleidende betonelementen aangelegd. Het betrof amfibietunnels, bedoeld om amfibieën en reptielen een veilige oversteek te bieden (Goois Natuurreservaat, 2003). In het voorjaar van 2018 is de weg gerenoveerd en zijn deze tunnels vervangen door zes nieuwe: opnieuw drie amfibietunnels, aangevuld met drie dassentunnels (Figuur 13). De tunnels hebben als doel om niet alleen amfibieën en reptielen, maar ook kleine en middelgrote zoogdieren een veilige oversteek te bieden. Al deze tunnels passeren zowel de rijbaan als het naastgelegen fietspad.

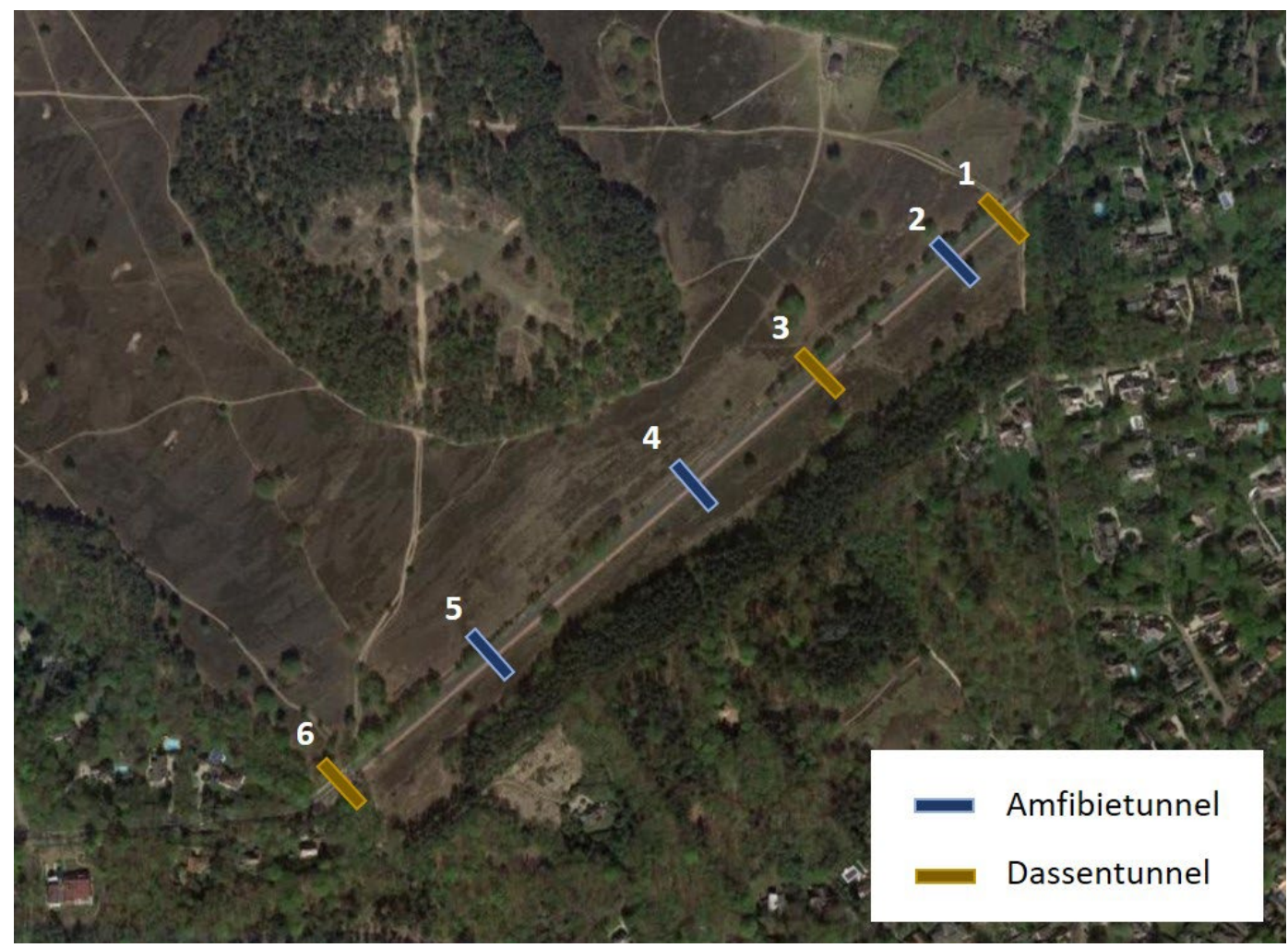

Figuur 13 Ligging van de in 2018 aangelegde kleine faunapassages onder de Boissevainweg. 
De amfibietunnels zijn van beton, rechthoekig (0,5 m breed, 0,57 $\mathrm{m}$ hoog) en circa $13 \mathrm{~m}$ (tunnel 2 en 4) of 17 m (tunnel 5) lang (ACO Pro klimaatportaal KP 1000-700) (Figuur 14). De bovenzijde van de amfibietunnels ligt in het wegdek en bevat openingen. De dassentunnels zijn ronde, betonnen buizen met een diameter van 0,4 m (Figuur 14).
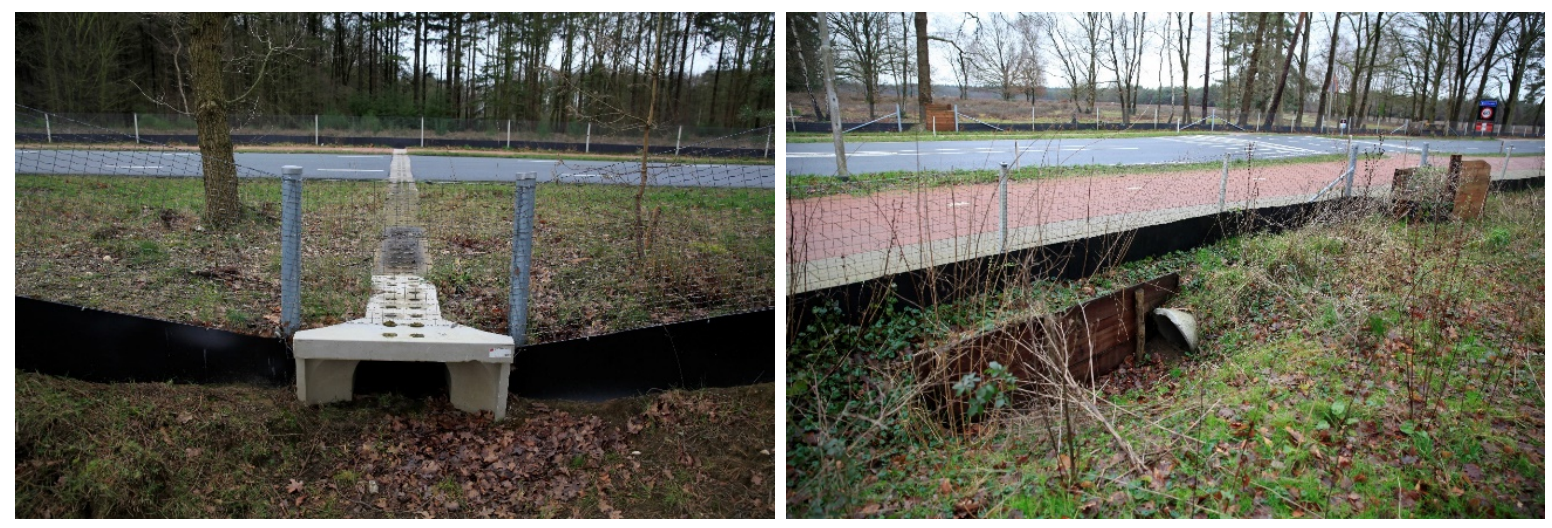

Figuur 14 Een amfibietunnel (links) en dassentunnel (rechts) onder de Boissevainweg.

In 2018 is aan weerszijden van de weg over een lengte van circa $1 \mathrm{~km}$ een faunakerend raster geplaatst (Figuur 15). Dit raster is circa $1 \mathrm{~m}$ hoog, ingegraven en bevat een circa 0,4 $\mathrm{m}$ hoog amfibiescherm aan de onderzijde. Aan de westzijde van de weg is dit raster ter hoogte van de amfibietunnels 2 en 4 in een V-vorm geplaatst. Deze V-vormige toeloop naar de tunnelingang is circa $4 \mathrm{~m}$ lang. Aan de oostzijde van de weg is dit niet gedaan. Rondom de drie dassentunnels zijn steeds vier insprongen aangelegd. Deze moeten dieren in staat stellen om het raster te passeren als ze toch onverhoopt aan de wegzijde van het raster zijn beland (Figuur 15).
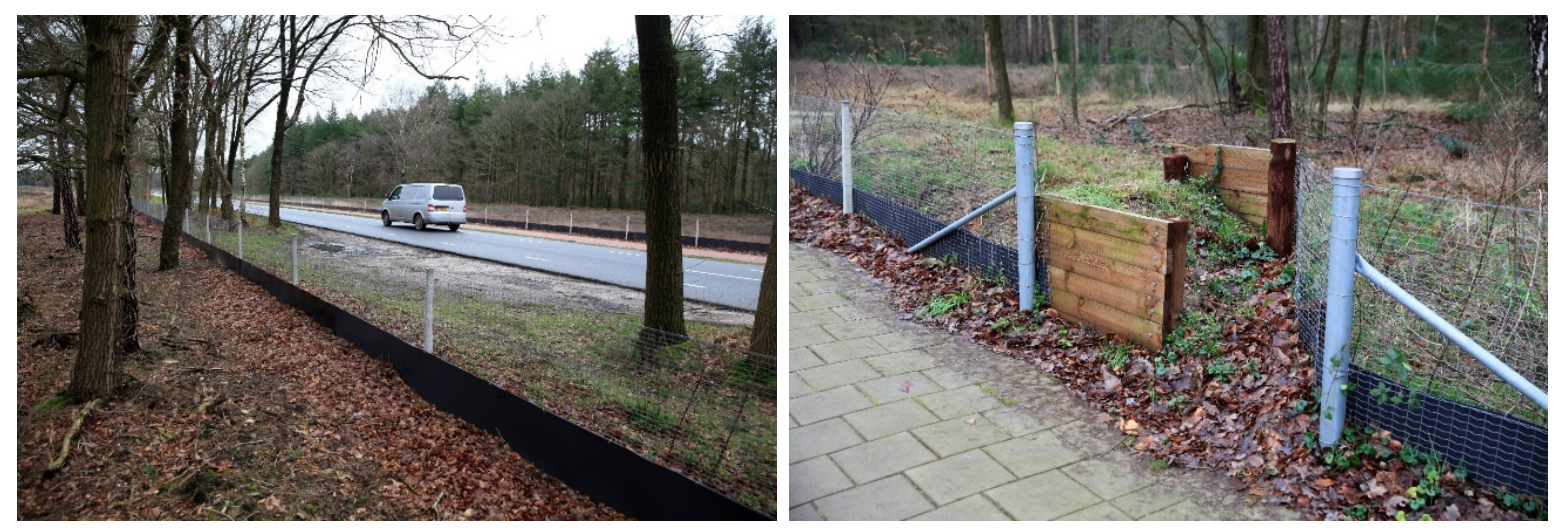

Figuur 15 Faunakerend raster aan weerszijden van de Boissevainweg (links) en een van de insprongen (rechts) die het mogelijk maakt dat dieren die tussen de rasters terecht zijn gekomen, het achterland weer kunnen bereiken. 


\section{Methoden}

\subsection{Inleiding}

In dit hoofdstuk beschrijven we de gebruikte onderzoeksmethoden. Paragraaf 3.2 presenteert het ontwerp van de studie. Paragraaf 3.3 presenteert het toetsingskader dat is gebruikt om het functioneren van de natuurbrug te evalueren. In paragraaf 3.4 zijn de gebruikte meetopstelling en het meet-plan beschreven. In paragraaf 3.5 is toegelicht hoe de met cameravallen verkregen fotobeelden zijn verwerkt. In paragraaf 3.6 en 3.7 is uiteengezet hoe de verzamelde gegevens van respectievelijk middelgrote zoogdieren en mensen/huisdieren zijn geanalyseerd. Ten slotte is in paragraaf 3.8 beschreven welke analyses zijn uitgevoerd om het effect van menselijk medegebruik van de natuurbrug op het gebruik door zoogdieren te onderzoeken.

\subsection{Ontwerp van de studie}

We beschrijven hier beknopt de studieopzet per onderzoeksvraag.

\section{Maken middelgrote zoogdieren gebruik van de natuurbrug, hoe frequent en op welke wijze doen zij dit en wordt hiermee aan vooraf gestelde doelen voor het gebruik van de natuurbrug voldaan?}

Allereerst is een toetsingskader opgesteld waarmee het gebruik van de natuurbrug kan worden geëvalueerd. Hierbij zijn meetbare doelen voor het gebruik door middelgrote zoogdieren geformuleerd. Het gebruik van de natuurbrug door middelgrote zoogdieren is vervolgens onderzocht met behulp van cameravallen. De zo verkregen fotobeelden laten niet alleen zien welke soorten passeren, maar ook hoe frequent zij dit doen en op welke wijze. Zo leggen de cameravallen het tijdstip van passeren vast, de snelheid waarmee de dieren passeren en het gedrag dat ze tijdens het passeren vertonen. Om de vraag te kunnen beantwoorden of hiermee aan vooraf gestelde doelen voor het gebruik van de natuurbrug wordt voldaan, zijn gelijktijdig metingen met cameravallen gedaan op willekeurig gekozen referentieplekken in de natuurgebieden rondom de natuurbrug. Dit stelt ons in staat om de aan- of afwezigheid van een diersoort op de natuurbrug beter te duiden. De metingen op de referentieplekken laten immers zien welke diersoorten in de omgeving van de natuurbrug aanwezig zijn. Daarnaast biedt deze opzet de mogelijkheid om waargenomen activiteit op de natuurbrug te vergelijken met die van deze soorten in de omgeving. Het biedt ook de kans om het functioneren van de natuurbrug voor een soort in een standaard indexwaarde uit te drukken waardoor metingen op verschillende plekken beter met elkaar kunnen worden vergeleken (Van der Grift \& Van der Ree, 2015).

\section{Wat is het effect van het menselijk medegebruik op het gebruik van de natuurbrug door deze zoogdieren?}

Onderzoek naar het effect van menselijk medegebruik op het gebruik van de natuurbrug door middelgrote zoogdieren zou bij voorkeur een studieopzet kennen waarbij metingen in een periode dat de brug niet is opengesteld voor mensen worden vergeleken met metingen in een periode dat de brug wel door mensen wordt gebruikt. Deze opzet was praktisch echter niet haalbaar. Daarom richten we ons in het onderzoek naar de effecten van het menselijk medegebruik niet op 'mensen wel/niet aanwezig', maar op verschillen in de intensiteit van het gebruik door mensen. We kijken dus naar drukke versus rustige dagen wat betreft het aantal mensen, en onderzoeken of het gebruik door middelgrote zoogdieren hieraan is gerelateerd. We richten ons hierbij op passagefrequentie en het tijdstip van passeren. Het gebruik van de natuurbrug door mensen is met cameravallen onderzocht. 
Maken middelgrote zoogdieren gebruik van Corridor Prinses Julianalaan en de kleine faunatunnels bij de Leemzeulder en de Boissevainweg en zo ja, hoe frequent is dit gebruik? Om te onderzoeken of middelgrote zoogdieren gebruikmaken van Corridor Prinses Julianalaan en hoe frequent dit gebruik dan is, is een veldstudie uitgevoerd met behulp van cameravallen. Om te onderzoeken of middelgrote zoogdieren gebruikmaken van de kleine faunatunnels bij de Leemzeulder en de Boissevainweg en hoe frequent dit gebruik dan is, is een veldstudie uitgevoerd met behulp van cameravallen en sporenplaten.

\section{Zijn er verbeteringen mogelijk wat de inrichting en het beheer van de natuurverbinding betreft en zo ja, welke?}

Om vast te stellen of er verbeteringen mogelijk zijn wat de inrichting en het beheer van de natuurbrug betreft, is verkend voor welke soorten het gebruik van de natuurbrug achterblijft bij de verwachtingen. Vervolgens is onderzocht wat hiervoor mogelijke oorzaken zijn en welke maatregelen genomen kunnen worden om deze verwachtingen wel waar te maken. Het betreft hier een expertoordeel.

\subsection{Toetsingskader}

We formuleren hier een aantal meetbare doelen voor het gebruik van de natuurbrug door middelgrote zoogdieren, waarmee het functioneren van deze faunapassage op transparante wijze kan worden geëvalueerd. We volgen hierbij de richtlijnen van Van der Grift \& Van der Ree (2015), die aanbevelen om doelen voor het gebruik van faunapassages te relateren aan een 'minimum verwacht gebruik'. Het gebruik van een faunapassage is niet alleen afhankelijk van bijvoorbeeld het ontwerp of de landschappelijke inpassing, maar ook van de lokale omstandigheden. Zo is de soortensamenstelling in de omliggende gebieden bepalend voor wat er in potentie aan soorten op een natuurbrug kan worden aangetroffen. En is de frequentie van passeren van een soort sterk afhankelijk van de populatiedichtheid. Dit 'minimum verwacht gebruik' bepalen we hier op basis van de metingen op de referentieplekken in de natuurgebieden rondom de natuurbrug.

Het eerste meetbare doel voor het gebruik van de natuurbrug hangt samen met de aanwijzing van doelsoorten:

> Doel 1: De middelgrote zoogdieren die als doelsoort voor de natuurbrug zijn aangewezen, maken gebruik van de natuurbrug.

Zoals in het voorgaande hoofdstuk beschreven, is het realiseren van een natuurverbinding op ecosysteemniveau het streven voor Natuurbrug Laarderhoogt. Dit betekent dat de brug ruimte moet bieden aan zowel bos als heide en in principe een verbindende functie moet hebben voor alle soorten die in deze biotopen voorkomen. Een tweede meetbaar doel voor de natuurbrug is daarom:

$>$ Doel 2: Middelgrote zoogdiersoorten die zijn geregistreerd op de referentieplekken rondom de natuurbrug maken alle gebruik van de natuurbrug.

Het aantal keer dat een soort passeert, is in veel gevallen een goede graadmeter voor de functionaliteit van een natuurbrug. Om hiervoor een meetbaar doel te stellen, is het nodig om per doelsoort te bepalen welk type gebruik wordt nagestreefd (Van der Grift \& Van der Ree, 2015). Globaal zijn er drie typen gebruik te onderscheiden: (1) frequent gebruik tijdens dagelijkse bewegingen binnen het leefgebied; (2) regelmatig gebruik tijdens seizoensgebonden bewegingen tussen verschillende delen van het leefgebied; (3) incidenteel gebruik tijdens dispersiebewegingen van (jonge) dieren op zoek naar een eigen territorium of nieuw leefgebied. Een soort die de natuurbrug slechts enkele keren per jaar passeert, doet het dus niet per definitie 'slechter' dan een soort die iedere dag passeert. Dat is afhankelijk van het gestelde doel voor het gebruik voor de betreffende soort.

Reeën komen al lange tijd in de gebieden aan zowel de zuid- als noordzijde van de natuurverbinding voor. Hier is dan ook sprake van een stabiele, gevestigde populatie. Bewegingen over de natuurbrug 
moeten deze soort in staat stellen om enerzijds binnen hun leefgebied voedsel, water of slaapplekken te bereiken, anderzijds om dispersiebewegingen van (jonge) dieren te faciliteren. Voor deze doelsoort kiezen we in dit verband dan ook de volgende meetbare doelen:

> Doel 3: Reeën maken frequent gebruik van de natuurbrug, gemiddeld eenmaal per dag.

> Doel 4: De trefkans van reeën op de natuurbrug is $>50 \%$, dus gemiddeld wordt/worden minimaal een op de twee dagen een of meer passerende reeën geregistreerd.

Het bos- en heidegebied direct ten zuiden van de natuurbrug is actueel leefgebied van de das. De aantallen zijn hier echter nog beperkt; binnen een straal van 2 kilometer is hier slechts één bewoonde dassenburcht aanwezig. In de gebieden ten noorden van de natuurbrug is de das ook waargenomen. Meestal als verkeersslachtoffer. De aantallen lijken ook hier beperkt. Van een stabiele, gevestigde populatie is hier nog geen sprake. Historische meldingen van aangereden boommarters op de A1 ter hoogte van Crailo en Laren laten zien dat de soort hier al langere tijd voorkomt (Wijsman, 2008). In het bos- en heidegebied direct ten zuiden van de natuurbrug is de boommarter incidenteel waargenomen. Het lijken vooral zwervende dieren te zijn, op zoek naar een partner en/of nieuw territorium (Van der Grift et al., 2010). Er zijn hier geen nestbomen van deze soort bekend. De dichtstbijzijnde plek waar voortplanting is vastgesteld, is het Spanderswoud, hemelsbreed meer dan 3 kilometer naar het westen (Wijsman, 2008). Boommarters zijn incidenteel ook waargenomen in de gebieden ten noorden van de natuurbrug, vooral als verkeersslachtoffer, maar voortplanting is niet vastgesteld (Wijsman et al., 2014). Van een stabiele, gevestigde populatie is hier daarom geen sprake. Bewegingen over de natuurbrug moeten deze twee doelsoorten aanvankelijk dus vooral in staat stellen om dispersie van (jonge) dieren te faciliteren en de kolonisatie en ontwikkeling van een stabiele populatie te bevorderen. Als doelen zijn daarom geformuleerd:

> Doel 5: Dassen en boommarters maken op de korte termijn incidenteel gebruik van de natuurbrug, minimaal tienmaal per jaar. Deze soorten maken op de lange termijn frequent gebruik van de natuurbrug, gemiddeld eenmaal per dag.

> Doel 6: Op de korte termijn is de trefkans van dassen en boommarters op de natuurbrug $>2 \%$, dus gemiddeld wordt/worden minimaal 7 dagen per jaar een of meer passerende dieren geregistreerd. Op de lange termijn is de trefkans voor deze soorten $>50 \%$.

Korte termijn is gedefinieerd als $<10$ jaar en lange termijn is $>10$ jaar na de aanleg van de natuurbrug. Dit onderzoek heeft 3-5 jaar na de aanleg van de natuurbrug plaatsgevonden, dus hier richten we ons uitsluitend op het gestelde doel voor de korte termijn.

Het absolute aantal passages van een soort vertelt echter niet het hele verhaal. Soorten die een gelijke passagefrequentie hebben, kunnen een heel verschillende betekenis hebben in een evaluatie van het succes van een natuurbrug. Bijvoorbeeld als de ene soort zeer algemeen is, terwijl de andere soort slechts in zeer lage dichtheden voorkomt. Een meetbaar doel voor de natuurbrug is daarom:

> Doel 7: De passagefrequentie van een doelsoort op de natuurbrug is minimaal gelijk aan de gemiddelde passagefrequentie van deze soort op referentieplekken binnen voor de soort geschikte biotopen.

Met dit doel wordt het aantal passages op de natuurbrug afgezet tegen het gemiddelde aantal passages binnen voor de soort geschikte biotopen in de omgeving. Omdat er binnen 'geschikte biotopen' echter gebieden kunnen zijn die voor de soort toch minder aantrekkelijk zijn of om andere redenen niet worden benut, is een tweede, iets 'ambitieuzer', meetdoel hier echter op z'n plaats:

> Doel 8: De passagefrequentie van een doelsoort op de natuurbrug is minimaal gelijk aan de gemiddelde passagefrequentie van deze soort op referentieplekken binnen voor de soort geschikte biotopen, waar de soort ook is aangetroffen. 
Gedurende een jaar laten zoogdieren meestal duidelijke verschillen in activiteit zien. Bijvoorbeeld tijdens perioden dat er een territorium gevestigd moet worden, in de voortplantingstijd of tijdens de winter. De activiteit op de natuurbrug in de tijd komt bij voorkeur overeen met die in de omgeving. De verdeling van passages over de maanden en seizoenen is dan ook een goede indicator om het functioneren van de natuurbrug te toetsen. Datzelfde geldt voor het tijdstip van passeren binnen het etmaal en de mate waarin de natuurbrug bij daglicht wordt gebruikt.

> Doel 9: De procentuele verdeling van het aantal passages op de natuurbrug over het jaar komt overeen met die op referentieplekken binnen voor de doelsoort geschikte biotopen.

> Doel 10: De procentuele verdeling van het aantal passages op de natuurbrug over het etmaal komt overeen met die op referentieplekken binnen voor de doelsoort geschikte biotopen.

> Doel 11: Het gemiddelde tijdstip waarop een doelsoort de natuurbrug passeert, komt overeen met het gemiddelde tijdstip van passeren op referentieplekken binnen voor de soort geschikte biotopen.

> Doel 12: De procentuele verdeling van het aantal passages over de lichttoestanden licht/schemer/donker op de natuurbrug komt overeen met die op referentieplekken binnen voor de doelsoort geschikte biotopen.

De aard van de individuen - wat betreft geslacht en leeftijd - die uitwisselen via de natuurbrug, is bij voorkeur gelijk aan die in de omgeving. Zinvolle meetdoelen in dit verband zijn dan ook:

> Doel 13: De geslachtsverhouding van een doelsoort op de natuurbrug komt overeen met de gemiddelde geslachtsverhouding op referentieplekken binnen voor de soort geschikte biotopen.

> Doel 14: De procentuele verdeling van het aantal passages van mannelijke dan wel vrouwelijke dieren op de natuurbrug over het jaar komt overeen met die op referentieplekken binnen voor de doelsoort geschikte biotopen.

> Doel 15: De leeftijdsverdeling van een soort op de natuurbrug komt overeen met de gemiddelde leeftijdsverdeling op referentieplekken binnen voor de soort geschikte biotopen.

$>$ Doel 16: De procentuele verdeling van het aantal passages van adulte dan wel juveniele dieren op de natuurbrug over het jaar komt overeen met die op referentieplekken binnen voor de doelsoort geschikte biotopen.

De manier waarop dieren een natuurbrug passeren, vertelt naar verwachting veel over de functionaliteit van de voorziening. Te denken valt aan de manier van lopen (loopwijze) tijdens het passeren en het gedrag dat de dieren vertonen tijdens het passeren. Idealiter zijn er geen verschillen met dieren die zich door het omliggende leefgebied bewegen. Dit zou immers betekenen dat de natuurbrug op dezelfde manier wordt 'ervaren' en gebruikt als een willekeurige plek in het leefgebied. Afwijkingen ten opzichte van metingen op referentieplekken kunnen erop duiden dat de dieren een zekere barrièrewerking ervaren of juist aangetrokken worden om de natuurbrug te gebruiken.

> Doel 17: De manier van lopen waarmee een doelsoort de natuurbrug passeert, komt overeen met de loopwijze op referentieplekken binnen voor de soort geschikte biotopen.

$>$ Doel 18: Het gedrag dat de doelsoort op de natuurbrug vertoont, komt overeen met het gedrag op referentieplekken binnen voor de soort geschikte biotopen.

Bovenstaande doelen zijn globaal in drie groepen te delen: (1) primaire doelen, (2) secundaire doelen en (3) tertiaire doelen. Primaire doelen zijn gedefinieerd als doelen die gericht zijn op het realiseren van de minimaal gewenste uitwisseling tussen de gebieden ten noorden en zuiden van de infrastructurele barrières. Dit zijn dus de doelen waarin de (doel)soorten (doel 1 en 2) en gewenste passage-frequenties (doel 3, 4, 5 en 6) zijn gespecificeerd. Secundaire doelen zijn gedefinieerd als doelen die gericht zijn op 
het maximaliseren van de uitwisseling. Dit zijn dus de doelen waarin de passage-frequentie van een doelsoort op de natuurbrug is gerelateerd aan de gemiddelde passagefrequentie op de referentieplekken (doel 7 en 8). Deze secundaire doelen zijn indicatief voor de mate waarin de barrièrewerking van de infrastructuur is opgeheven (zie ook paragraaf 3.6). Tertiaire doelen zijn gedefinieerd als doelen die gericht zijn op het karakter van de uitwisseling. Dit zijn dus de doelen waarin is gespecificeerd wat de verdeling van de passages over het jaar en etmaal is (doel 9, 10, 11 en 12), wat de aard is van de individuen die uitwisselen (geslachtsverhouding, leeftijdsverdeling; doel 13, 14, 15 en 16) en wat de manier van passeren is (loopwijze en gedrag; doel 17 en 18). De primaire doelen hebben de hoogste prioriteit. Deze hangen immers direct samen met de mate van uitwisseling die de natuurbrug (minimaal) moet faciliteren. Aan de secundaire en tertiaire doelen kan een lagere prioriteit worden toegekend. Dat een dier de overkant haalt, is bijvoorbeeld belangrijker dan de manier waarop het dier dat doet, in stap en rustig grazend of in galop zonder te stoppen.

\subsection{Verzamelen gegevens}

\subsubsection{Natuurbrug Laarderhoogt}

Het gebruik van de natuurbrug is onderzocht met behulp van zes cameravallen. Deze zijn op het ecoduct over de Naarderstraat geplaatst. Voor deze plek is gekozen, omdat dit ecoduct de plek is waar de verbinding het smalst is. Dit maakt het eenvoudiger om de natuurbrug over de hele breedte te monitoren. Een belangrijker argument was echter dat als dieren deze plek passeren, het aannemelijk is dat ze dat ook doen op plekken waar de natuurverbinding breder is. Omgekeerd hoeft dat niet het geval te zijn. Vijf cameravallen zijn in palen geïnstalleerd op een hoogte van $4 \mathrm{~m}$ boven het maaiveld. Vier hiervan zijn gericht op de natuurzone zonder menselijk medegebruik en één op de natuurzone met menselijk medegebruik (Figuur 16).
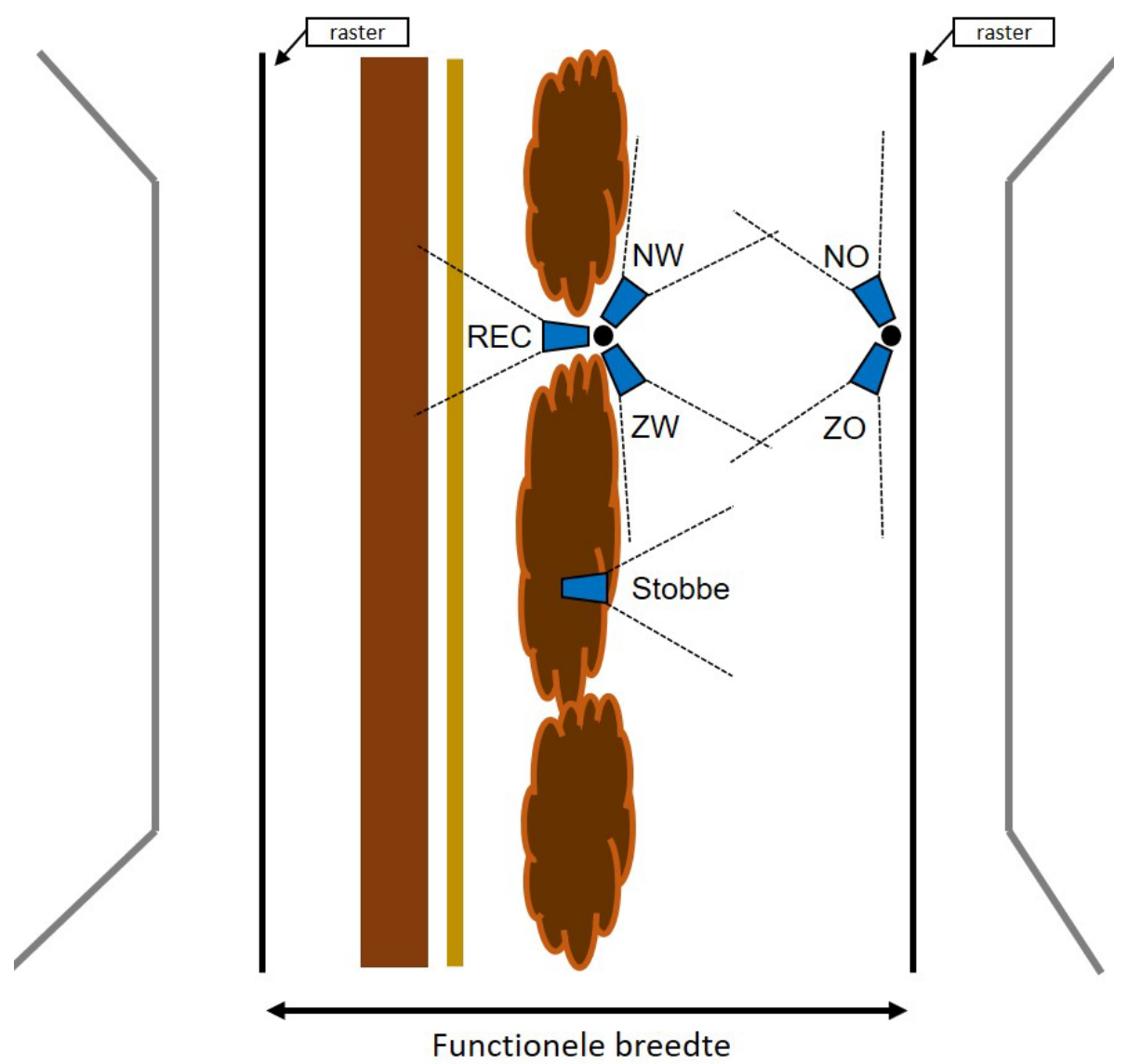

Figuur 16 Schematische weergave van de opstelling van de cameravallen op Natuurbrug Laarderhoogt. 
De camera's zijn alle schuin naar beneden gericht in een hoek van 60 graden. De zichtvelden van de twee naar het noorden gerichte camera's - NO en NW - overlapten elkaar deels. Datzelfde gold voor de twee camera's - ZO en ZW - die naar het zuiden waren gericht. De vijfde camera (REC) was naar het westen gericht en registreerde bewegingen van mens en dier in de natuurzone met menselijk medegebruik. De camera's in de palen waren van het type Reconyx MicroFire MR5. Deze infraroodcamera met bewegings- en warmtesensor heeft een reactietijd van 0,1 sec, een maximaal detectie-bereik van $12 \mathrm{~m}$ en een flitsbereik (infrarood) van $15 \mathrm{~m}$ (Figuur 17).

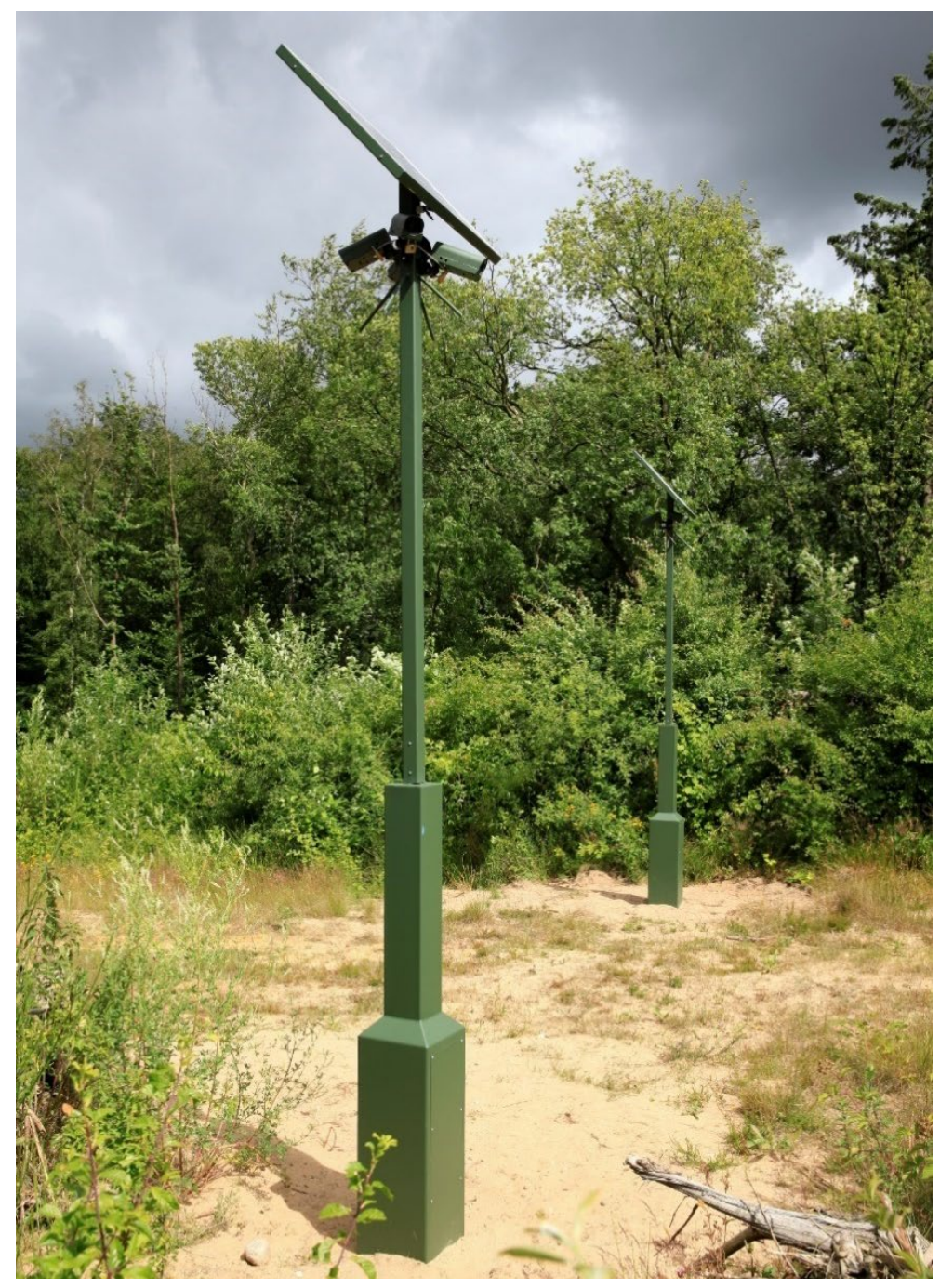

Figuur 17 De palen met cameravallen op Natuurbrug Laarderhoogt, kort na de installatie.

Plaatsing van de camera's in palen, waarbij passerende dieren schuin van boven worden gefotografeerd, is niet de meest optimale opstelling. Plaatsing op min of meer 'ooghoogte' van de doelsoorten, dwars op de verwachte looprichting, heeft de voorkeur. Hiermee worden passerende dieren immers van opzij gefotografeerd, waardoor ze meestal in meer detail in beeld komen. Hier is toch voor plaatsing in palen gekozen in verband met herhaalde diefstal en vernieling van cameravallen elders in het Gooi. Om te onderzoeken of en zo ja, in welke mate, het aantal registraties van passerende dieren door de op palen geplaatste camera's verschilt van die bij een optimale plaatsing, is één camera (STOBBE; Figuur 16) op circa 0,75 m hoogte in de stobbenwal geplaatst met het zichtveld dwars op de looprichting van de dieren. Deze camera is gebruikt om het aantal registraties door de camera's NO, NW, ZO en ZW te ijken (zie paragraaf 3.6). Camera STOBBE was van het type Reconyx HyperFire PC900. Deze infraroodcamera met bewegings- en warmtesensor heeft een reactietijd van $0,2 \mathrm{sec}$, maximaal detectiebereik van $30 \mathrm{~m}$ en een flitsbereik (infrarood) van $20 \mathrm{~m}$. De registraties van passerende mensen door camera REC zijn geijkt door gedurende een dagdeel gelijktijdig met de camera ook een handmatige telling uit te voeren. 
De monitoring van de natuurbrug is voor de duur van 1 jaar uitgevoerd; periode 1 juli 201830 juni 2019. De cameravallen waren in principe 7 dagen per week, 24 uur per dag actief. Door technische storingen - onder meer door uitvallende zonnepanelen - hebben echter niet alle camera's 365 dagen gewerkt. Tabel 3.1 geeft een overzicht van het aantal dagen dat iedere cameraval op de natuurbrug operationeel was. Omdat de cameraparen $\mathrm{NO}+\mathrm{NW}$ en $\mathrm{ZO}+\mathrm{ZW}$ beide de hele breedte van de natuurzone zonder menselijk medegebruik dekten, wat ook geldt voor de camera die in de stobbenwal is geplaatst, is deze zone desondanks wel voor 365 dagen gemonitord (Figuur 18). Voor de natuurzone met menselijk medegebruik geldt dat niet, aangezien camera REC de enige was die op dit deel van de natuurbrug stond gericht. Hier zijn uiteindelijk 103 volledige dagen gemonitord tijdens de onderzoeksperiode.

Tabel 3.1 Het aantal volledige dagen dat de cameravallen op Natuurbrug Laarderhoogt operationeel zijn geweest tijdens de onderzoeksperiode.

\begin{tabular}{lllllllllllllll} 
& 2018 & \multicolumn{1}{c}{ Camera } & J & A & S & O & N & D & J & F & M & A & M & J \\
NO & 0 & 16 & 30 & 31 & 30 & 31 & 31 & 28 & 31 & 30 & 31 & 30 & 319 \\
\hline NW & 31 & 31 & 30 & 31 & 30 & 31 & 31 & 28 & 31 & 30 & 31 & 30 & 365 \\
\hline ZO & 25 & 31 & 30 & 31 & 30 & 31 & 31 & 28 & 31 & 30 & 31 & 30 & 359 \\
\hline ZW & 20 & 21 & 5 & 31 & 30 & 31 & 31 & 28 & 31 & 30 & 31 & 30 & 319 \\
\hline STOBBE & 23 & 31 & 15 & 31 & 30 & 31 & 16 & 0 & 0 & 0 & 0 & 0 & 177 \\
\hline REC & 16 & 0 & 5 & 22 & 24 & 31 & 5 & 0 & 0 & 0 & 0 & 0 & 103 \\
\hline Totaal & $\mathbf{1 1 5}$ & $\mathbf{1 3 0}$ & $\mathbf{1 1 5}$ & $\mathbf{1 7 7}$ & $\mathbf{1 7 4}$ & $\mathbf{1 8 6}$ & $\mathbf{1 4 5}$ & $\mathbf{1 1 2}$ & $\mathbf{1 2 4}$ & $\mathbf{1 2 0}$ & $\mathbf{1 2 4}$ & $\mathbf{1 2 0}$ & $\mathbf{1 . 6 4 2}$ \\
\hline
\end{tabular}

Op het moment dat een cameraval door een passerend dier werd geactiveerd, maakte de camera tien opnamen direct na elkaar. Dit maakte het mogelijk om diverse kenmerken van de observatie goed vast te leggen, zoals looprichting, manier van lopen en gedrag. Als een dier na de tiende opname nog in het sensorveld van de camera aanwezig was, is de camera een nieuwe reeks van tien foto's gestart. De camera registreert voor iedere gemaakte foto een groot aantal (technische) gegevens automatisch in een database, waaronder datum en tijdstip van de opname. 


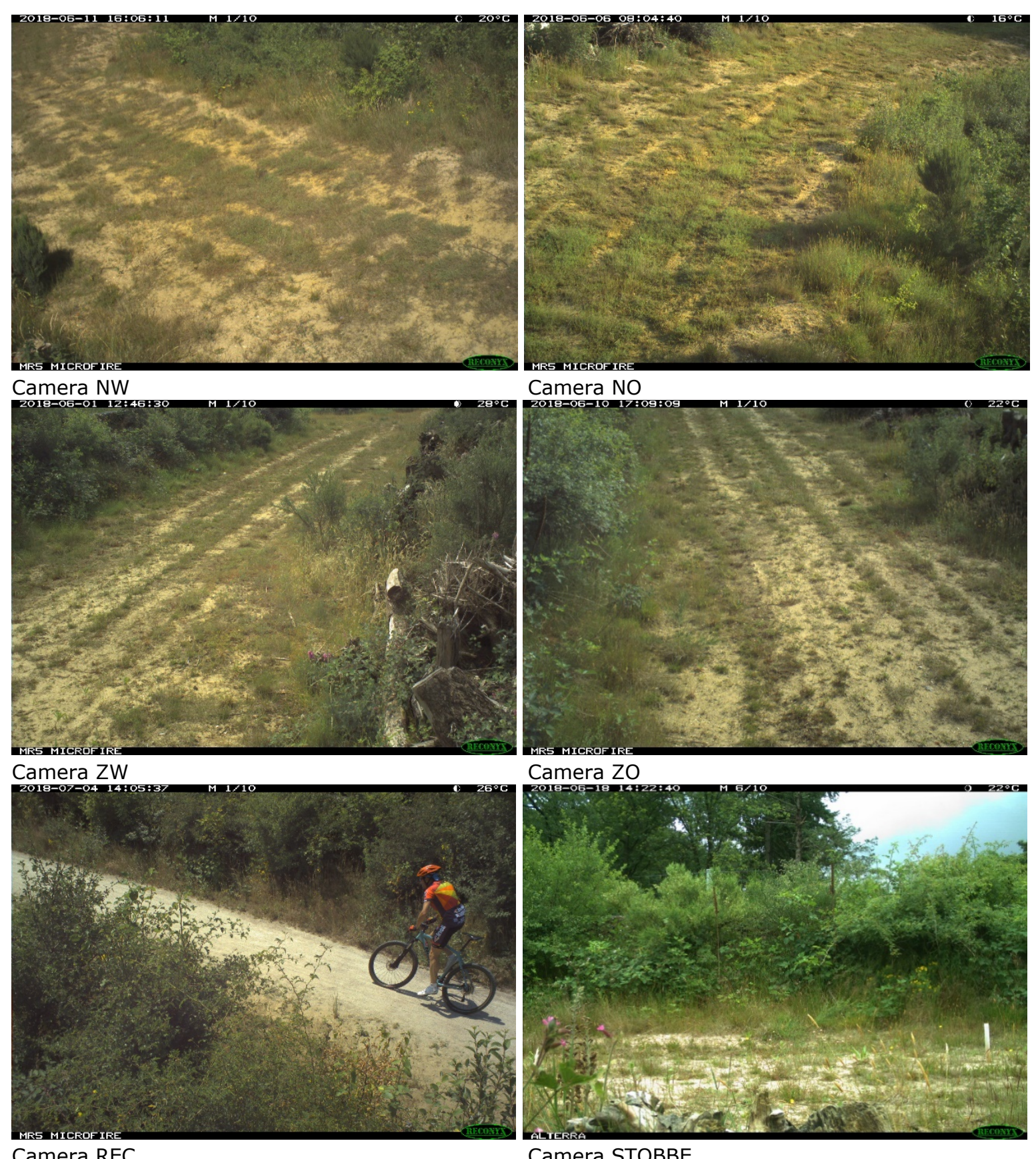

Camera REC

Camera STOBBE

Figuur 18 Zichtvelden van de cameravallen op Natuurbrug Laarderhoogt. 


\subsubsection{Referentieplekken}

In de natuurgebieden rondom de natuurbrug zijn op twaalf locaties cameravallen opgesteld die als referentie zijn gebruikt voor de metingen op de natuurbrug. Zes hiervan liggen aan de noordzijde en zes aan de zuidzijde van de natuurverbinding (Figuur 19). Deze referentieplekken zijn random - dus willekeurig of 'door loting' - bepaald binnen een straal van twee kilometer vanaf de natuurbrug. Hiervoor is gebruikgemaakt van de ASELECT-functie in Microsoft Excel, waarmee willekeurige X- en Ycoördinaten binnen het onderzoeksgebied zijn gegenereerd. De referentieplekken liggen in de biotopen bos of heide (Tabel 3.2). Op iedere referentieplek is een cameraval geïnstalleerd van het type Reconyx HyperFire PC900 (Figuur 20). De camera's zijn op een hoogte van 0,6 m boven maaiveld gehangen. Het zichtveld van de camera's is eveneens random bepaald (Figuur 21).

De monitoring op de referentieplekken is gelijktijdig met de metingen op de natuurbrug uitgevoerd; periode 1 juli 2018-30 juni 2019. De cameravallen waren in principe 7 dagen per week, 24 uur per dag actief. Door incidentele verstoringen van de positie van camera's - door mensen, grote grazers en storm - hebben echter niet alle camera's 365 dagen goede opnamen gemaakt. Daarnaast zijn er drie camera's (02, 08 en O11) in de loop van het onderzoek gestolen, zodat ook op deze plekken niet alle dagen is gemonitord. Tabel 3.3 geeft een overzicht van het aantal dagen dat iedere cameraval in de omgeving van de natuurbrug operationeel was. De monitoring op de referentieplekken omvat in totaal 3.714 opnamedagen.

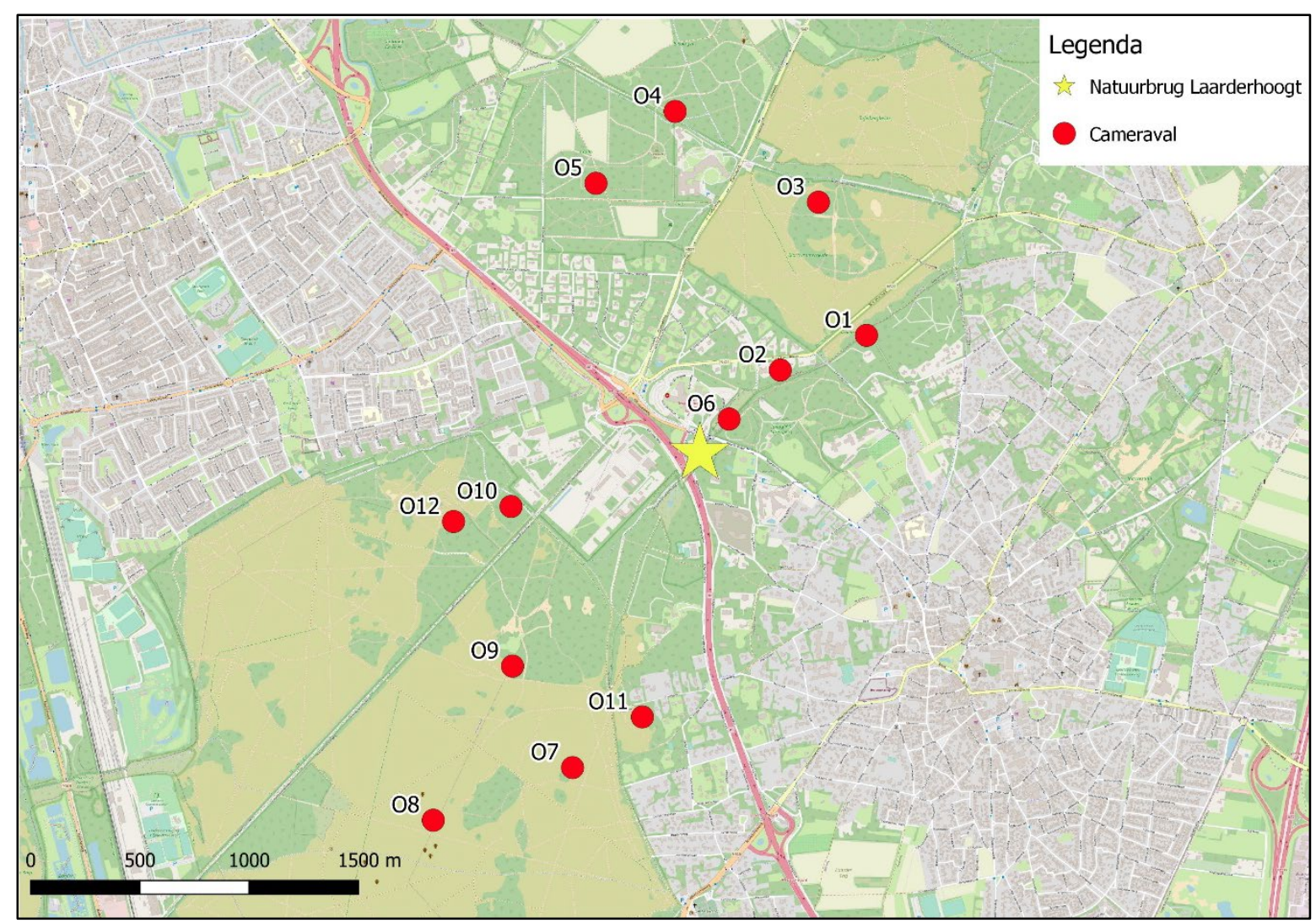

Figuur 19 Ligging van de twaalf willekeurig gekozen referentieplekken in de natuurgebieden rondom Natuurbrug Laarderhoogt. 
Tabel 3.2 Ligging van de referentieplekken ten opzichte van de naturverbinding en de biotoop die in het zichtveld van de cameraval ligt.

\begin{tabular}{lll} 
Referentieplek & Ligging & Biotoop \\
\hline 01 & noord & Bos \\
\hline 02 & noord & Bos \\
\hline 03 & noord & Bos \\
\hline 05 & noord & Bos \\
\hline 06 & noord & Bos \\
\hline 07 & noord & Heide \\
\hline 08 & zuid & Heide \\
\hline 010 & zuid & Heide \\
\hline 011 & zuid & Bos \\
\hline 012 & zuid & Heide \\
\hline
\end{tabular}
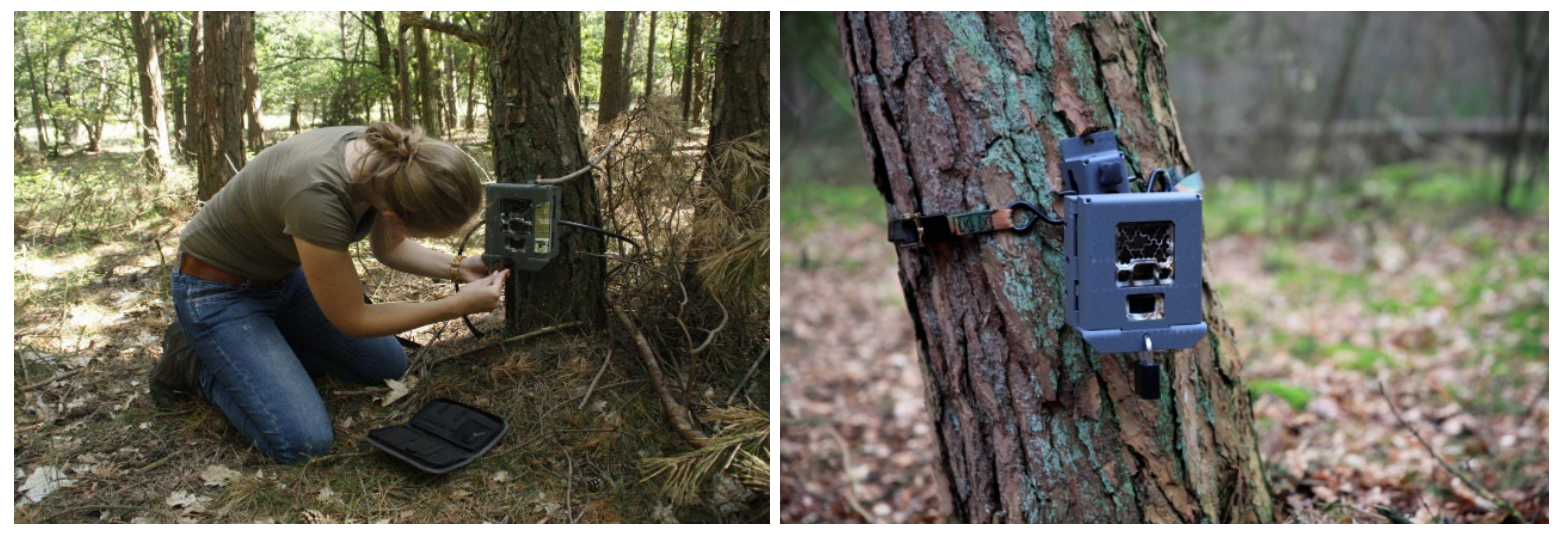

Figuur 20 Installatie van een cameraval (links) en een operationele cameraval (rechts) op een van de referentieplekken rond Natuurbrug Laarderhoogt. 


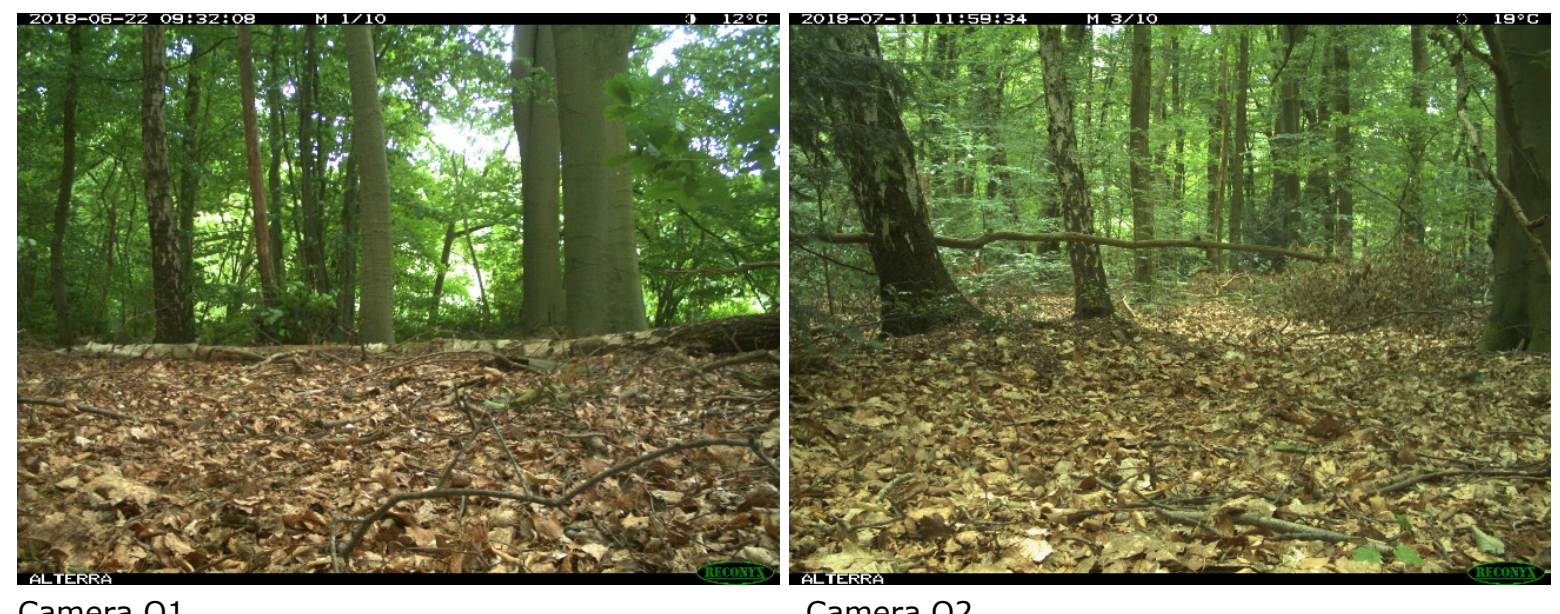

Camera $\mathrm{O} 1$

Camera $\mathrm{O} 2$
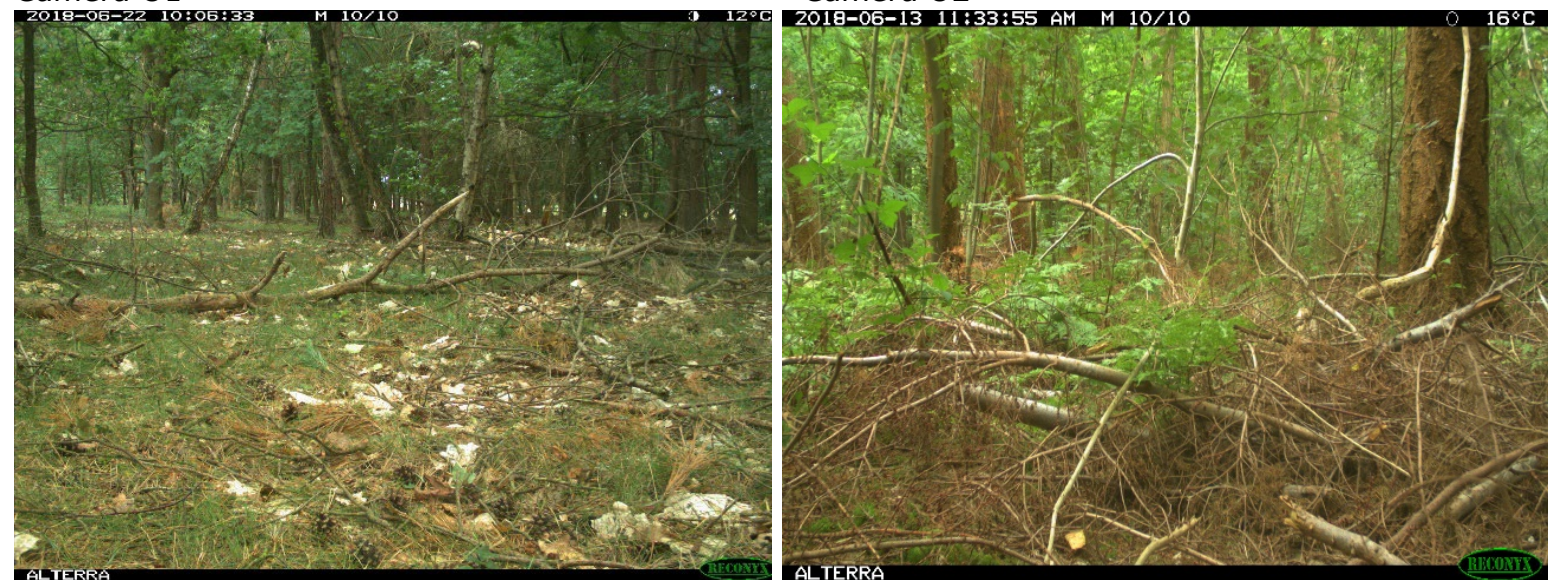

Camera $\mathrm{O} 3$

Camera $\mathrm{O} 4$
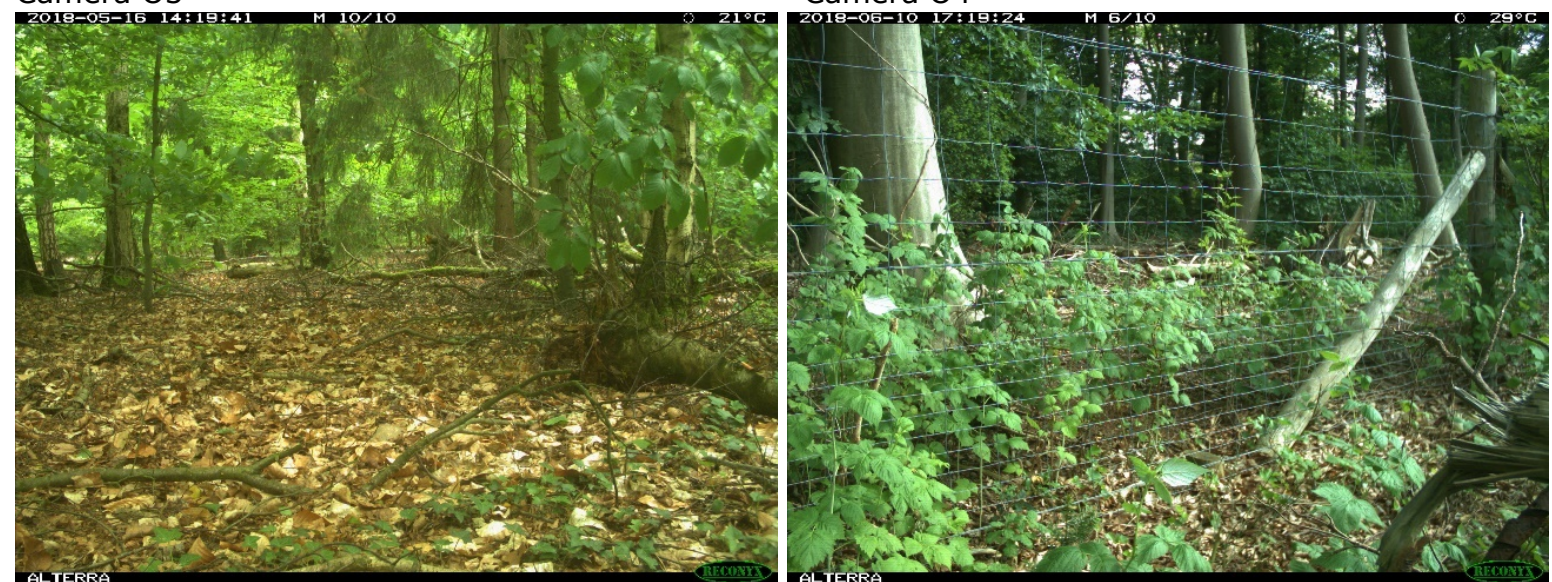

\section{Camera 05}

Camera 06

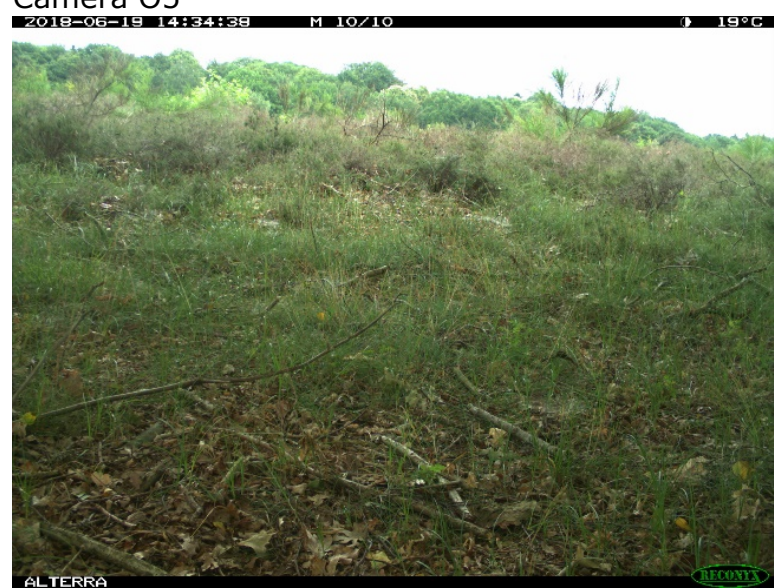

Camera 07

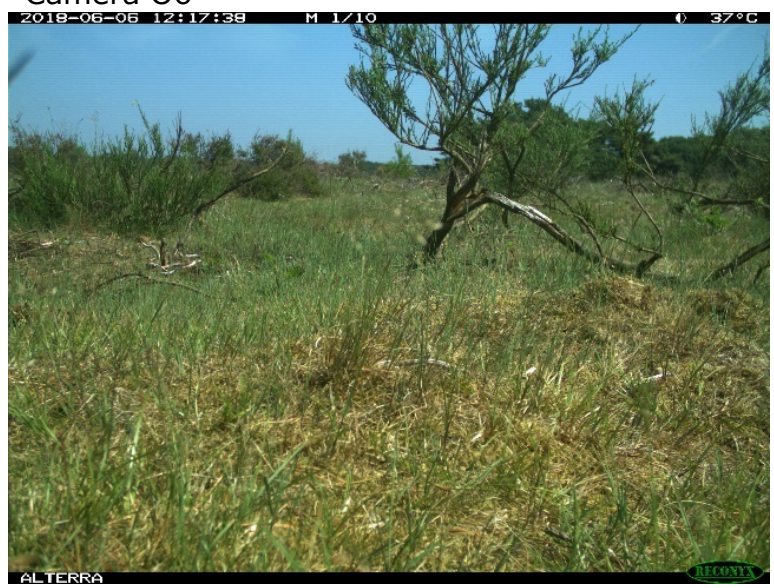

Camera 08 

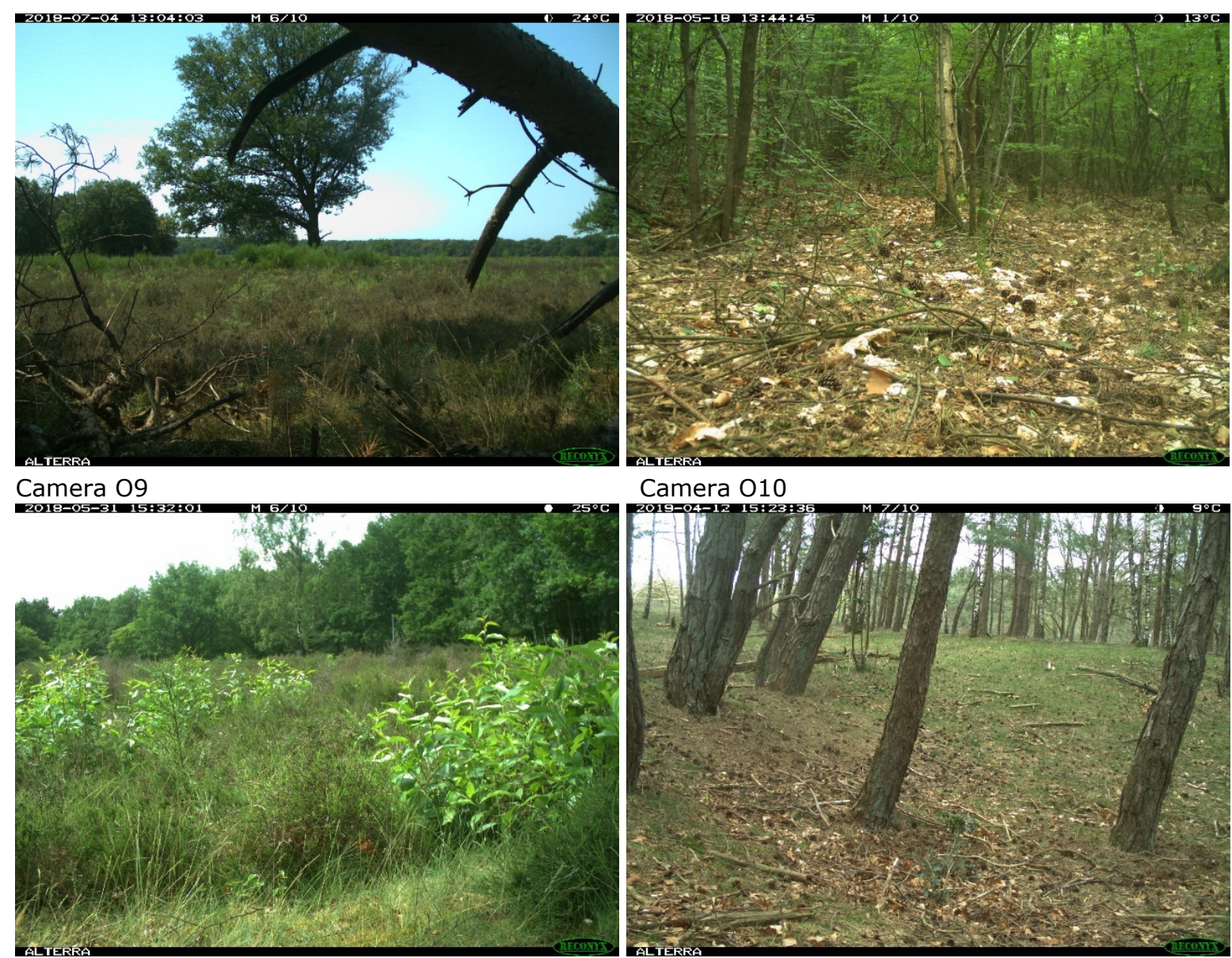

Camera 011

Camera 010

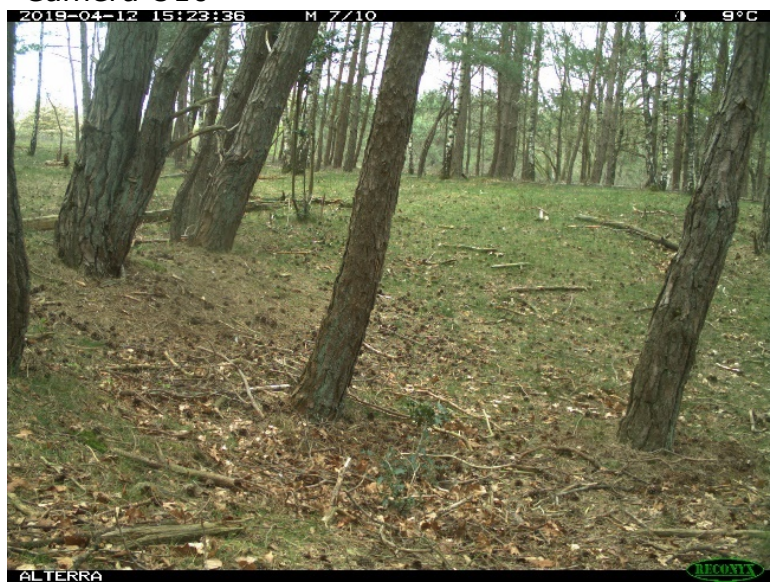

Camera 012

Figuur 21 Zichtvelden van de cameravallen op de twaalf referentieplekken in de omgeving van Natuurbrug Laarderhoogt.

Tabel 3.3 Het aantal volledige dagen dat de cameravallen op de referentieplekken operationeel zijn geweest tijdens de onderzoeksperiode.

\begin{tabular}{|c|c|c|c|c|c|c|c|c|c|c|c|c|c|}
\hline \multirow[b]{2}{*}{ Camera } & \multicolumn{6}{|c|}{2018} & \multicolumn{6}{|c|}{2019} & \multirow[b]{2}{*}{ Totaal } \\
\hline & J & A & s & 0 & $\mathbf{N}$ & D & J & $F$ & M & A & M & J & \\
\hline $\mathrm{O} 1$ & 24 & 21 & 30 & 31 & 30 & 31 & 31 & 28 & 31 & 30 & 31 & 30 & 348 \\
\hline $\mathrm{O} 2$ & 24 & 25 & 30 & 31 & 30 & 9 & $*$ & $*$ & $*$ & $*$ & $*$ & $*$ & 149 \\
\hline $\mathrm{O} 3$ & 31 & 31 & 30 & 31 & 30 & 31 & 31 & 28 & 31 & 30 & 31 & 30 & 365 \\
\hline $\mathrm{O} 4$ & 8 & 31 & 30 & 31 & 30 & 31 & 31 & 28 & 31 & 30 & 31 & 30 & 342 \\
\hline 05 & 19 & 31 & 30 & 31 & 8 & 31 & 31 & 28 & 31 & 30 & 31 & 30 & 331 \\
\hline 06 & 31 & 31 & 30 & 31 & 30 & 31 & 31 & 28 & 2 & 26 & 31 & 30 & 332 \\
\hline 07 & 31 & 31 & 30 & 31 & 30 & 31 & 31 & 28 & 31 & 30 & 31 & 30 & 365 \\
\hline 08 & 14 & 31 & 30 & 31 & 30 & 31 & 31 & 28 & 31 & 3 & $*$ & $*$ & 260 \\
\hline 09 & 31 & 31 & 30 & 31 & 30 & 31 & 31 & 28 & 31 & 30 & 31 & 30 & 365 \\
\hline $\mathrm{O} 10$ & 16 & 31 & 30 & 31 & 30 & 31 & 31 & 28 & 31 & 30 & 31 & 30 & 350 \\
\hline O11 & 22 & 31 & 30 & 31 & 30 & 31 & 22 & $*$ & $*$ & $*$ & * & $*$ & 197 \\
\hline $\mathrm{O} 12$ & 31 & 31 & 30 & 31 & 30 & 31 & 31 & 4 & 0 & 30 & 31 & 30 & 310 \\
\hline Totaal & 282 & 356 & 360 & 372 & 338 & 350 & 332 & 256 & 250 & 269 & 279 & 270 & 3.714 \\
\hline
\end{tabular}

* Geen data - cameraval gestolen. 


\subsubsection{Corridor Prinses Julianalaan}

Het gebruik van Corridor Prinses Julianalaan is onderzocht met behulp van twee cameravallen (C1 en $\mathrm{C2}$ ). Deze zijn min of meer in het centrale deel van de corridor geplaatst, op circa $200 \mathrm{~m}$ afstand van de Leemzeulder. De camera's zijn op $4 \mathrm{~m}$ boven maaiveld in een boom geplaatst. De camera's zijn schuin naar beneden gericht in een hoek van 60 graden. Het zichtveld van camera $\mathrm{C} 1$ was gericht op het voet-/ruiterpad (Figuur 22). Het zichtveld van camera C2 was gericht op de bosstrook die ten westen van het pad ligt. De camera's waren van het type Reconyx MicroFire MR5.

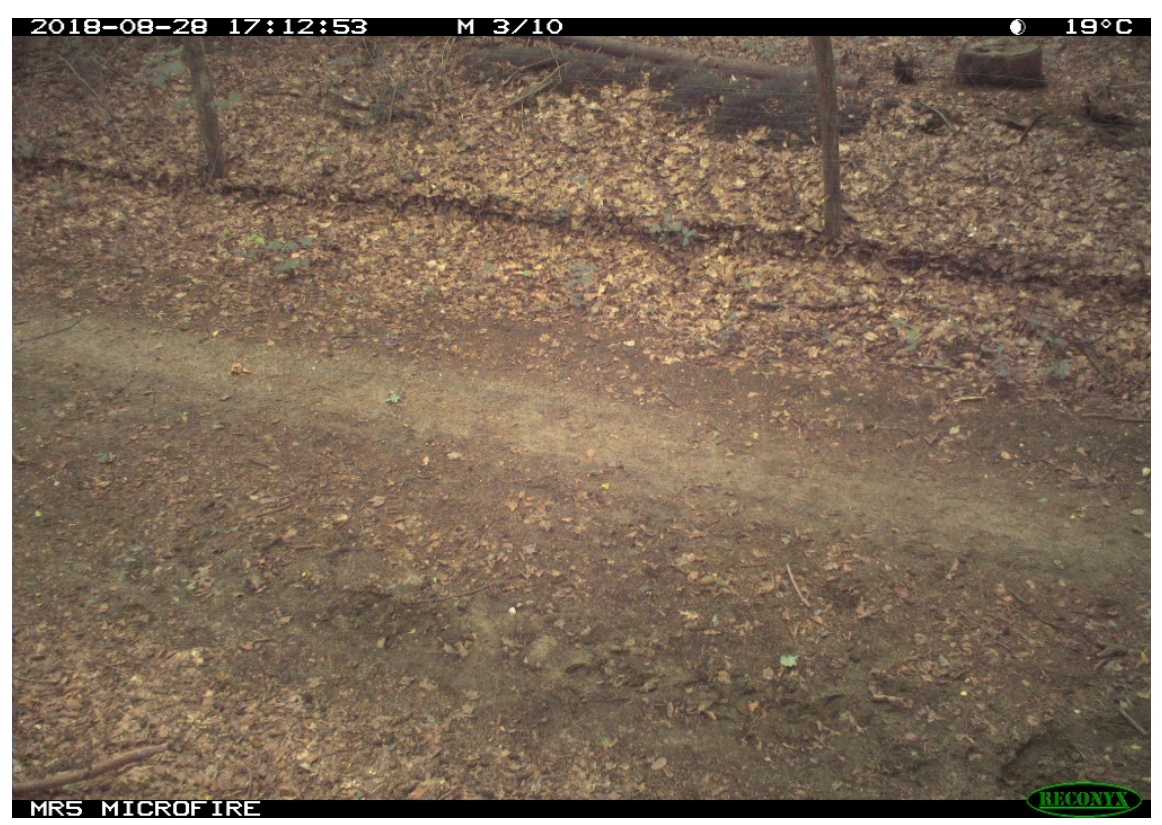

Figuur 22 Zichtveld van cameraval C1 in Corridor Prinses Julianalaan.

De monitoring van de corridor is gelijktijdig met de metingen op de natuurbrug uitgevoerd; periode 1 juli 2018-30 juni 2019. De cameravallen waren in principe 7 dagen per week, 24 uur per dag actief. Door technische storingen heeft camera C1 echter niet alle dagen gewerkt en heeft camera C2 helemaal geen goede beelden opgeleverd. Cameraval $\mathrm{C} 1$ is in totaal 128 dagen operationeel geweest (Tabel 3.4). Het ontbreken van beelden van camera C2 betekent dat de corridor slechts voor $50 \%$ is gemonitord.

Tabel 3.4 Het aantal volledige dagen dat de cameravallen in Corridor Prinses Julianalaan operationeel zijn geweest tijdens de onderzoeksperiode.

\begin{tabular}{|c|c|c|c|c|c|c|c|c|c|c|c|c|c|}
\hline \multirow[b]{2}{*}{ Camera } & \multicolumn{6}{|c|}{2018} & \multicolumn{6}{|c|}{2019} & \multirow[b]{2}{*}{ Totaal } \\
\hline & J & A & s & 0 & $\mathbf{N}$ & D & J & $F$ & M & $\mathbf{A}$ & M & $\mathbf{J}$ & \\
\hline $\mathrm{C} 1$ & 30 & 20 & 0 & 0 & 13 & 31 & 31 & 3 & 0 & 0 & 0 & 0 & 128 \\
\hline
\end{tabular}

\subsubsection{Faunatunnels Leemzeulder}

Het gebruik van de faunatunnels onder de Leemzeulder door middelgrote zoogdieren is onderzocht met behulp van sporenplaten. Een sporenplaat bestaat uit een 2,2 m lange houten plaat die in de tunnel kan worden geschoven. De breedte van de sporenplaat is gelijk aan de breedte van de tunnelbodem. De sporenplaat in de amfibietunnel was 0,48 m breed, die in de dassentunnel was 0,35 $\mathrm{m}$ breed. De sporenplaat bevat in het midden een inktbed $(0,6 \mathrm{~m}$ lang) en aan beide uiteinden een papiervel (0,8 m lang). De 'inkt' bestaat uit een mengsel van paraffine en koolstofpoeder. Dieren die over het inktbed lopen, laten vervolgens sporen op het papier achter. Op basis van deze sporen is 
bepaald welke soorten gebruikmaken van de tunnels en hoe frequent zij dit doen. De faunatunnels onder de Leemzeulder zijn, direct nadat deze zijn aangelegd, voor een periode van vier maanden gemonitord; 1 maart 2019-30 juni 2019. De sporenplaten zijn gemiddeld eenmaal per twee weken gecontroleerd. Hierbij is het papier vervangen en het inktbed bijgevuld.

\subsubsection{Faunatunnels Boissevainweg}

Het plan was om het gebruik van de faunatunnels onder de Boissevainweg door middelgrote zoogdieren te onderzoeken met behulp van cameravallen. Tijdens de testfase, in juni 2018, zijn echter direct drie van de zes camera's gestolen. De drie overgebleven camera's zijn daarom weggehaald en is er besloten om de tunnels met behulp van sporenplaten te onderzoeken. (Zie voor de beschrijving van een sporenplaat paragraaf 3.4.4). De faunatunnels onder de Boissevainweg zijn voor een periode van 12 maanden gemonitord; 1 juli 2018-30 juni 2019. De sporenplaten zijn gemiddeld eenmaal per twee weken gecontroleerd. Hierbij is het papier vervangen en het inktbed bijgevuld (Figuur 23).
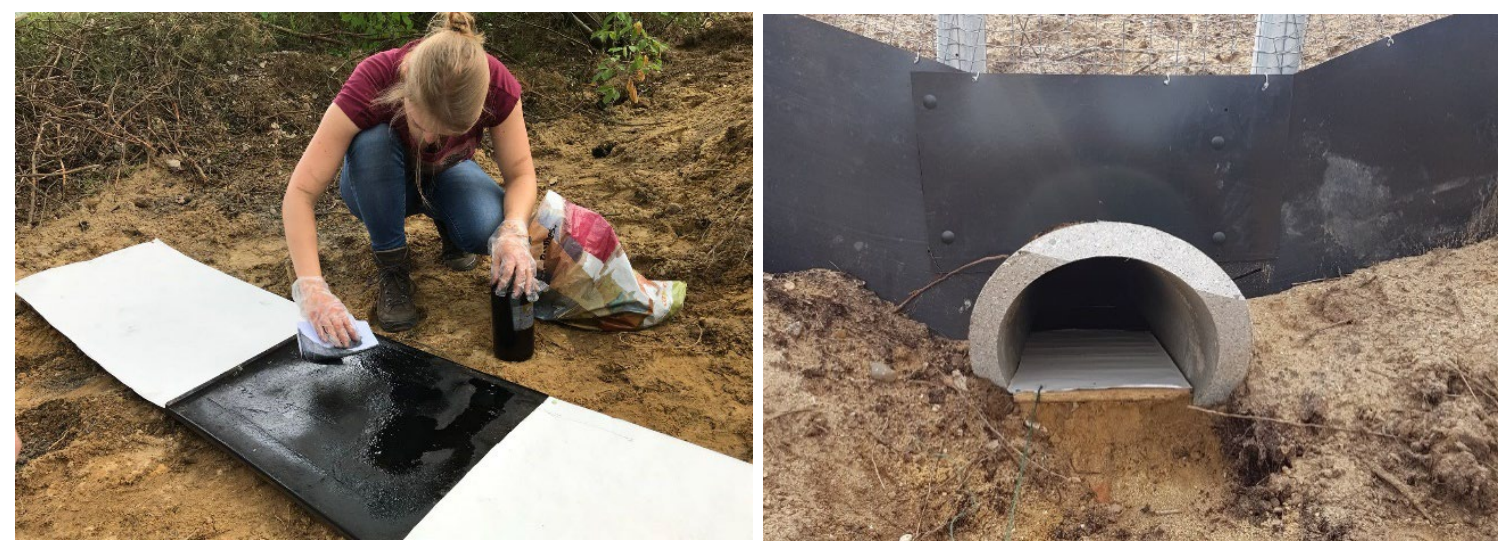

Figuur 23 Preparatie van een sporenplaat (links) en een sporenplaat die in een van de dassentunnels onder de Boissevainweg is geschoven (rechts).

\subsection{Verwerken van de fotobeelden}

De fotobeelden van de cameravallen zijn alle geanalyseerd, waarbij per waargenomen dier de volgende meetvariabelen in een database zijn opgenomen: (1) soort, (2) geslacht, (3) leeftijd, (4) looprichting, (5) loopwijze, (6) gedrag en (7) lichtsituatie. Tabel 3.5 geeft een overzicht van de mogelijke waarden per meetvariabele.

Voor 'looprichting' is geregistreerd of het dier in het fotobeeld van rechts naar links of links naar rechts beweegt, dan wel aan de rechter- of linkerkant van het fotobeeld blijft. Pas in de analysefase zijn deze richtingen 'vertaald' in een geografische richting, op basis van de positionering van de betreffende camera. Zo betekent een looprichting 'rechts-links' voor een dier dat met camera STOBBE op de natuurbrug is waargenomen dat het dier van zuid naar noord bewoog. Het gedrag van de dieren is geregistreerd door voor zes typische gedragingen te scoren of deze wel/niet zijn vertoond. Een waargenomen dier kan een of meerdere gedragingen laten zien. Als een van de eerste vijf meetvariabelen niet met zekerheid kon worden vastgesteld, is 'onbekend' ingevuld. 
Tabel 3.5 Meetvariabelen en bijbehorende warden die bij de analyse van de fotobeelden zijn geregistreerd voor waargenomen middelgrote zoogdieren.

\begin{tabular}{ll} 
Meetvariabelen & Waarden \\
Soort & soortnaam, onbekend \\
\hline Geslacht & man, vrouw, onbekend \\
\hline Leeftijd & adult, juveniel, onbekend \\
\hline Looprichting & rechts-links, links-rechts, rechts-rechts, links-links, onbekend \\
\hline Loopwijze & stap, draf, galop, huppelgang, sprongengalop, onbekend \\
\hline Gedrag & \\
\hline passeert & ja/nee \\
\hline zit/staat & ja/nee \\
\hline alert & ja/nee \\
\hline foerageert/jaagt & ja/nee \\
\hline markeert & ja/nee \\
\hline overig (liggen, wassen, graven) & ja/nee \\
\hline Lichtsituatie & licht, schemer, donker \\
\hline
\end{tabular}

Voor mensen zijn de volgende meetvariabelen geregistreerd: (1) de wijze van voortbewegen; (2) of het de persoon was toegestaan om op de betreffende plek te zijn; (3) of de persoon deel uitmaakte van het onderzoeksteam of niet; (4) looprichting. Voor huisdieren zijn alleen de soort en looprichting geregistreerd. Voor honden is daarnaast aangegeven of deze was aangelijnd of losliep. Tabel 3.6 geeft een overzicht van de mogelijke waarden per meetvariabele.

Voor de wijze van voortbewegen van mensen zijn vier groepen onderscheiden: (1) voetganger, (2) fietser, (3) ruiter en (4) overig. De groep 'voetganger' omvat zowel wandelaars als joggers, maar ook (ski)skaters. De groep 'fietser' omvat alle typen fietsen, dus stadsfietsen, racefietsen, mountainbikes, e-bikes, bakfietsen, tandems, duofietsen, stepfietsen en driewielers. De groep 'ruiter' omvat ruiters, ongeacht of ze op het paard zitten of ernaast lopen, en aanspanningen. De groep 'overig' omvat alle mensen die op een andere wijze passeerden, i.e. per auto, tractor, motor, brommer, scooter en scootmobiel. Als de persoon niet op de betreffende plek mocht zijn, is deze geregistreerd als 'illegaal'. Was hiervoor wel toestemming, dan is deze geregistreerd als 'legaal'. Een recreant te voet in het natuurdeel van de natuurbrug is dus gelabeld als illegaal, maar een recreant te voet op het fiets-/voetpad is legaal. Een recreant op een brommer op het fiets-/voetpad is daarentegen weer illegaal. Recreanten op de referentieplekken zijn eveneens illegaal, want deze camera's staan alle binnen de percelen en bezoekers mogen hier niet van de paden af. Een uitzondering vormen recreanten die referentieplek 012 bezochten: deze cameraval stond vlak bij een geocache waar de beheerder van het terrein toestemming voor heeft verleend. De looprichting van mensen en huisdieren is op vergelijkbare wijze geregistreerd als voor de wilde zoogdieren. Als de looprichting niet met zekerheid kon worden vastgesteld, is 'onbekend' ingevuld.

Tabel 3.6 Meetvariabelen en bijbehorende waarden die bij de analyse van de fotobeelden zijn geregistreerd voor waargenomen mensen en huisdieren.

\begin{tabular}{ll} 
Meetvariabelen & Waarden \\
Mensen & voetganger, fietser, ruiter, overig \\
\hline Wijze van voortbewegen & legaal, illegaal \\
\hline Toestemming aanwezigheid & $j a / n e e$ \\
\hline Onderzoeker & $R L, L R, R R, L L$, onbekend \\
\hline Looprichting & \\
\hline Huisdieren & soortnaam \\
\hline Soort & RL, LR, RR, LL, onbekend \\
\hline Looprichting & aangelijnd, niet aangelijnd \\
\hline Type (alleen voor hond) &
\end{tabular}




\subsection{Analyse gegevens zoogdieren}

\subsubsection{Definities}

Een passage definiëren we hier als een waarneming of 'vangst' van een dier met een cameraval. De looprichting van het dier speelt hierbij geen rol; ook dieren die alleen maar stilzitten aan een kant van het fotobeeld, zijn een 'passage'. Het aantal passages is met deze definitie een maat voor activiteit en maakt het mogelijk om de activiteit van dieren op de natuurbrug te vergelijken met die in de omgeving. Hebben dieren op de natuurbrug wel een duidelijke looprichting - noord-zuid of zuid-noord -, dan spreken we hier van een 'bevestigde oversteek'. Hebben dieren dat niet, dan spreken we van een 'bezoek'.

\subsubsection{Aantal passages op de natuurbrug}

Om het aantal passages van een soort op de natuurbrug te schatten, zijn de volgende stappen doorlopen:

\section{Stap 1: Verwijderen dubbeltellingen}

Omdat de zichtvelden van de camera's NO en NW en de camera's ZO en ZW deels overlappen en omdat zowel camerapaar NO/NW en ZO/ZW de hele breedte van de natuurzone zonder menselijk medegebruik monitoren, zijn dieren in veel gevallen door meerdere camera's geregistreerd. Als we hiervoor niet corrigeren, zou dit leiden tot een overschatting van het aantal passages. Alle door deze vier camera's geregistreerde passages zijn daarom met elkaar vergeleken en dubbeltellingen zijn uitgefilterd. Bij deze vergelijking zijn niet alleen datum en tijdstip van passage betrokken, maar ook het geslacht, de leeftijd en de looprichting van de dieren. De loopwijze en het gedrag zijn bij het vergelijken van passages niet betrokken, omdat deze snel kunnen wisselen en verschillende camera's dus een andere loopwijze of andere gedragingen van hetzelfde dier kunnen vastleggen.

\section{Stap 2: IJking tellingen met behulp van camera STOBBE}

Omdat monitoring met cameravallen die hoog op palen zijn geplaatst naar verwachting niet de optimale opstelling is, is het aantal passages - exclusief dubbeltellingen - geijkt op basis van de metingen van de camera die in de stobbenwal is geplaatst. Hierbij is onderzocht of, en in welke mate, het aantal passages verandert als we bij het verwijderen van dubbeltellingen ook de fotobeelden van camera STOBBE betrekken. Op basis van eventuele veranderingen in het aantal passages is vervolgens per soort een correctiefactor berekend. Door het in stap 1 bepaalde aantal passages te vermenigvuldigen met deze correctiefactor, per soort, is vervolgens het aantal passages in de natuurzone zonder menselijk medegebruik geschat. Op deze wijze kon voor vier soorten een correctiefactor worden bepaald (Tabel 3.7). Voor de boommarter en eekhoorn kon dit niet, omdat deze soorten tijdens de ijkingsperiode niet door de camera's in de palen zijn geregistreerd. Voor de bunzing kon dit niet, omdat deze soort tijdens de ijkingsperiode niet is gepasseerd.

Tabel 3.7 Het aantal passages in de natuurzone zonder menselijk medegebruik, bepaald op basis van de vier camera's in de palen exclusief dan wel inclusief de fotobeelden van camera STOBBE, het percentage toename in het aantal passages als camera STOBBE is meegenomen en de hieruit afgeleide correctiefactor.

\begin{tabular}{|c|c|c|c|c|}
\hline Soort & $\begin{array}{l}\text { Aantal passages } \\
\text { natuurzone zonder } \\
\text { medegebruik, excl. } \\
\text { Camera STOBBE }\end{array}$ & $\begin{array}{l}\text { Aantal passages } \\
\text { natuurzone zonder } \\
\text { medegebruik, incl. } \\
\text { Camera STOBBE }\end{array}$ & $\begin{array}{l}\text { Percentage } \\
\text { toename aantal } \\
\text { passages }\end{array}$ & Correctiefactor \\
\hline Ree & 390 & 449 & 15 & 1,15 \\
\hline Vos & 88 & 95 & 8 & 1,08 \\
\hline Boommarter & 0 & 1 & - & - \\
\hline Bunzing & 0 & 0 & - & - \\
\hline Haas & 13 & 53 & 308 & 4,08 \\
\hline Eekhoorn & 0 & 1 & - & - \\
\hline
\end{tabular}


Stap 3: Schatting aantal passages per jaar in de natuurzone met menselijk medegebruik De natuurzone met menselijk medegebruik is slechts voor een deel (103 dagen) van de onderzoeksperiode gemonitord. Het aantal hier geregistreerde passages van middelgrote zoogdieren is dan ook een onderschatting van het werkelijke aantal dat hier is gepasseerd. Om hiervoor te corrigeren, is het geregistreerde aantal passages per soort naar een jaar geëxtrapoleerd middels: aantal geregistreerde passages / aantal opnamedagen $* 365$. Hierbij geldt de aanname dat het gemiddelde aantal passages voor de opnamedagen representatief is voor het gemiddelde aantal passages op de dagen dat niet is gemonitord.

\section{Stap 4: Sommatie van het geschatte aantal passages in de beide zones}

In deze stap tellen we de schattingen van het aantal passages in de natuurzone zonder menselijk medegebruik (stap 2) en natuurzone met menselijk medegebruik (stap 3) bij elkaar op.

\subsubsection{Percentage bevestigde oversteken natuurbrug}

Het percentage passages op de natuurbrug dat kan worden geclassificeerd als een 'bevestigde oversteek' is bepaald op basis van de registraties die in de natuurzone zonder menselijk medegebruik door de camera's NO, NW, ZO, ZW en STOBBE zijn gedaan, exclusief dubbeltellingen, en die in de natuurzone met menselijk medegebruik door camera REC zijn gedaan. Het percentage is als volgt berekend: aantal passages met looprichting LR of RL / aantal passages alle looprichtingen * 100 .

\subsubsection{Passagefrequentie op de natuurbrug}

Omdat de onderzoeksperiode precies een jaar was, is het geschatte aantal passages ook direct de passagefrequentie per jaar. De passagefrequenties per dag, week en maand zijn berekend door dit aantal door respectievelijk 365, 52 en 12 te delen.

\subsubsection{Passagefrequentie op de referentieplekken}

Voor de referentieplekken in de omgeving is de passagefrequentie per jaar voor een soort als volgt berekend: aantal geregistreerde passages van de soort op de referentieplek / aantal opnamedagen op de referentieplek $* 365$.

\subsubsection{Vergelijking passagefrequentie natuurbrug versus omgeving}

Om de passagefrequenties van de natuurbrug te kunnen vergelijken met die in de omgeving zijn voor iedere soort drie stappen doorlopen:

\section{Stap 1: Standaardisatie passagefrequentie referentieplekken}

De passagefrequentie per jaar is voor iedere referentieplek gestandaardiseerd naar de functionele breedte van de natuurbrug op basis van de detectieafstand van de soort. Dit is gedaan met behulp van een correctiefactor die berekend is volgens: functionele breedte natuurbrug / detectieafstand van de soort (Tabel 3.8). De detectieafstand is hier gedefinieerd als de maximale afstand waarover de camera een soort nog kan waarnemen. De detectieafstand is, behalve van het type camera en de diersoort, afhankelijk van een groot aantal factoren, zoals het protocol dat is gebruikt voor het opstellen van de camera's, aanwezige begroeiing, weersomstandigheden, seizoen, hoeveelheid daglicht etc. De hier gebruikte detectieafstanden zijn schattingen, gebaseerd op eerder onderzoek (Van der Grift, ongepubliceerde data). De gestandaardiseerde passagefrequenties zijn verkregen door de berekende passagefrequentie voor een referentieplek (zie paragraaf 3.6.5) te vermenigvuldigen met de correctiefactor. 
Tabel 3.8 Per soort de detectieafstand van de cameravallen op de referentieplekken en de hiervan afgeleide correctiefactor voor het standaardiseren van de passagefrequentie, zodat een vergelijk met de passagefrequenties op de natuurbrug mogelijk wordt. Tevens de biotopen die voor de tijdens het onderzoek geregistreerde soorten als geschikt worden geacht.

\begin{tabular}{llll} 
Soort & Detectieafistand cameraval & $\begin{array}{l}\text { Correctiefactor } \\
\text { passagefrequentie }\end{array}$ & Geschikte biotopen \\
Ree & 10 & 2,25 & Bos / Heide \\
\hline Vos & 7,5 & 3 & Bos / Heide \\
\hline Das & 7,5 & 3 & Bos Heide \\
\hline Boommarter & 7,5 & 3 & Bos / Heide \\
\hline Bunzing & 5 & 4,5 & Bos / Heide \\
\hline Haas & 7,5 & 3 & Bos / Heide \\
\hline Konijn & 5 & 4,5 & Bos \\
\hline Egkhoorn & 5 & 4,5 & Bos \\
\hline
\end{tabular}

\section{Stap 2: Berekening gemiddelde passagefrequentie omgeving}

Voor de omgeving is de gemiddelde passagefrequentie per jaar berekend door het gemiddelde te nemen van de jaarlijkse passagefrequenties die in stap 1 voor de afzonderlijke referentieplekken zijn berekend. Met deze werkwijze wegen alle referentieplekken even zwaar in de berekening van het gemiddelde. Hierbij zijn twee varianten onderscheiden: (1) een gemiddelde dat is gebaseerd op alle referentieplekken die binnen geschikte biotoop liggen voor de betreffende soort, en (2) een gemiddelde dat is gebaseerd op de referentieplekken die binnen geschikte biotoop liggen voor de betreffende soort en waar de soort ook is aangetroffen. Tabel 3.7 geeft een overzicht van de geschikt geachte biotopen per soort.

\section{Stap 3: Berekening stuwingsindex}

Er is een zogenoemde 'stuwingsindex' (SI) berekend voor beide bij stap 2 genoemde varianten. Hiervoor zijn twee rekenregels gebruikt:

- Als de passagefrequentie op de natuurbrug groter is dan de gemiddelde passagefrequentie voor de omgeving, dan geldt:

$\mathrm{SI}$ = passagefrequentie natuurbrug / gemiddelde passagefrequentie omgeving

- Als de passagefrequentie op de natuurbrug kleiner is dan de gemiddelde passagefrequentie voor de omgeving, dan geldt:

$\mathrm{SI}=$ gemiddelde passagefrequentie omgeving / passagefrequentie natuurbrug * -1

Als $\mathrm{SI}=1$, dan zijn de passagefrequenties op de natuurbrug en in de omgeving dus gelijk. Bij een $\mathrm{SI}>1$ is de passagefrequentie op de natuurbrug groter dan die in de omgeving. Er is dan sprake van 'stuwing' of 'trechteren'; het aantal passages is er dan hoger dan je op basis van de metingen op de referentieplekken zou mogen verwachten. Bij een $\mathrm{SI}<-1$ is de passagefrequentie op de natuurbrug kleiner dan die in de omgeving. Er is dan sprake van 'vermijding' of 'barrièrewerking'; het aantal passages is er dan lager dan je op basis van de metingen op de referentieplekken zou mogen verwachten.

\subsubsection{Trefkans op de natuurbrug}

De trefkans is de kans, uitgedrukt in een percentage, dat een soort op een willekeurige dag in het jaar op de natuurbrug wordt aangetroffen. Deze is als volgt berekend: het aantal dagen dat de soort - dus een of meer individuen - op de natuurbrug is geregistreerd tijdens de onderzoeksperiode / 365 dagen * 100. Een trefkans van $50 \%$ betekent dus dat een soort gemiddeld eenmaal per twee dagen passeert.

\subsubsection{Procentuele verdeling passages over het jaar}

De procentuele verdeling over het jaar van het aantal passages op de natuurbrug en in de omgeving zijn met elkaar vergeleken. De maand is hierbij gebruikt als kleinste tijdseenheid. Voor de natuurbrug 
zijn hiervoor eerst de aantallen passages per maand geschat. Hierbij zijn dezelfde stappen gevolgd als beschreven in paragraaf 3.6.2. Dubbeltellingen zijn er dus uitgehaald, er is gecorrigeerd op basis van de ijking met de camera in de stobbenwal en het aantal passages in de natuurzone met menselijk medegebruik is eerst geëxtrapoleerd alvorens deze zijn gesommeerd met die in de natuurzone zonder menselijk medegebruik. Vervolgens is voor de natuurbrug berekend hoeveel procent van het jaarlijkse aantal passages in iedere maand plaatsvindt.

Voor de omgeving zijn de aantallen passages eerst per referentieplek berekend op basis van: aantal geregistreerde passages van de soort op de referentieplek in maand $X$ / aantal opnamedagen op de referentieplek in maand $X *$ aantal dagen in maand $X$. Vervolgens is, per maand, het gemiddelde aantal passages berekend, waarbij alleen referentieplekken in voor de soort geschikte biotoop zijn meegenomen. Vervolgens is voor de omgeving berekend hoeveel procent van het gemiddelde aantal passages per jaar in iedere maand plaatsvindt. Een Chi-square-test is gebruikt om vast te stellen of eventuele gevonden verschillen in de verdeling van de passages over het jaar statistisch significant $(p \leq 0,05)$ zijn of niet. Hierbij was de nulhypothese dat de proportionele verdeling van de passages over het jaar op de natuurbrug en in de omgeving niet verschilt. ${ }^{2}$

\subsubsection{Procentuele verdeling passages over het etmaal}

De procentuele verdeling over het etmaal van het aantal passages op de natuurbrug en in de omgeving zijn voor iedere soort met elkaar vergeleken. Uur is hierbij gebruikt als kleinste tijdseenheid. Voor de natuurbrug zijn hiervoor de geregistreerde passages van een soort gebruikt, zowel die in de natuurzone zonder menselijk medegebruik als de natuurzone met menselijk medegebruik, waarbij dubbeltellingen zijn uitgefilterd. Voor de omgeving zijn hiervoor de geregistreerde passages van een soort op de referentieplekken gebruikt, onder voorwaarde dat op de dag van de passage het hele etmaal is gemeten. Vervolgens is voor zowel de natuurbrug als de referentieplekken per uur berekend hoeveel procent van het aantal passages plaatsvond. Tabel 3.9 geeft het aantal passages dat in deze analyse is betrokken per soort, voor zowel de omgeving als natuurbrug.

Tabel 3.9 Per soort het aantal passages dat bij het bepalen van de procentuele verdeling van passages over het etmaal is gebruikt, voor de omgeving en natuurbrug.

\begin{tabular}{lll} 
Soort & Omgeving & Natuurbrug \\
Ree & 381 & 672 \\
\hline Vos & 220 & 378 \\
\hline Das & 3 & 50 \\
\hline Boommarter & 11 & 7 \\
\hline Bunzing & 2 & 19 \\
\hline Haas & 198 & 204 \\
\hline Konijn & 315 & 0 \\
\hline Eekhoorn & 62 & 2 \\
\hline Egel & 5 & 0 \\
\hline
\end{tabular}

Een Chi-square-test is gebruikt om vast te stellen of eventuele gevonden verschillen in de verdeling van de passages over het etmaal statistisch significant $(p \leq 0,05)$ zijn of niet. Hierbij was de nulhypothese dat de proportionele verdeling van de passages over het etmaal op de natuurbrug en in de omgeving niet verschilt.

\subsubsection{Gemiddeld tijdstip van passage}

Om het gemiddelde tijdstip van passeren voor een soort te berekenen, zijn allereerst alle tijden van passage geconverteerd naar tijden in een fictief etmaal dat start om 12:00 uur en eindigt om 12:00 uur de volgende dag. Alle passages die tussen 12:00 en 24:00 uur plaatsvonden, zijn dus

\footnotetext{
2 Alle statistische analyses in dit onderzoek zijn uitgevoerd met GENSTAT (19e editie).
} 
omgezet naar tijden tussen 0:00 en 12:00 uur. En passages die tussen 0:00 en 12:00 uur plaatsvonden, zijn omgezet naar tijden tussen 12:00 en 24:00 uur. Vervolgens zijn de (aangepaste) tijden van passage geconverteerd naar een tijdwaarde, i.e. een serieel getal voor tijd tussen 0 (00:00:00) en 0,999988426 (23:59:59). Daarna is het gemiddelde berekend van deze tijdwaardes, waarna de gemiddelde tijdwaarde weer is geconverteerd naar tijd in het fictieve etmaal. Ten slotte is die tijd weer omgezet in de werkelijke tijd binnen een etmaal van 0:00 tot 24:00 uur. Voor de natuurbrug zijn hiervoor de geregistreerde passages van een soort gebruikt, zowel die in de natuurzone zonder menselijk medegebruik als natuurzone met menselijk medegebruik, waarbij dubbeltellingen zijn uitgefilterd. Voor de omgeving zijn in deze berekening alleen passages betrokken die plaatsvonden op dagen dat het gehele etmaal metingen zijn verricht. Het verschil in tijdstip van passage tussen de omgeving en de natuurbrug is bepaald door de gemiddelde tijden van passage van elkaar af te trekken. Een two-sample t-test is gebruikt om vast te stellen of een gevonden verschil statistisch significant $(p \leq 0,05)$ is of niet. Hierbij was de nulhypothese dat de gemiddelde tijd van passage op de natuurbrug en in de omgeving niet verschilt.

\subsubsection{Verdeling van passages over lichttoestand}

De procentuele verdeling van het aantal passages bij daglicht, in de schemering en in het donker op de natuurbrug en in de omgeving is voor iedere soort met elkaar vergeleken. Voor de natuurbrug zijn hiervoor de geregistreerde passages van een soort gebruikt, zowel die in de natuurzone zonder menselijk medegebruik als natuurzone met menselijk medegebruik, waarbij dubbeltellingen zijn uitgefilterd. Voor de omgeving zijn hiervoor de geregistreerde passages van een soort op de referentie-plekken gebruikt, onder voorwaarde dat op de dag van de passage het hele etmaal is gemeten. Vervolgens is voor zowel de natuurbrug als de referentieplekken berekend hoeveel procent van het aantal passages in iedere periode plaatsvindt. Een Chi-square-test is gebruikt om vast te stellen of een gevonden verschil statistisch significant $(p \leq 0,05)$ is of niet. Hierbij was de nulhypothese dat de proportionele verdeling van de passages over de verschillende lichttoestanden op de natuurbrug en in de omgeving niet verschilt.

\subsubsection{Geslachtsverhouding}

Het geslacht van de dieren was alleen voor de doelsoort ree goed vast te stellen. Bij sommige van de andere diersoorten kon het geslacht incidenteel worden bepaald, maar dit leverde onvoldoende gegevens op voor een vergelijkende analyse.

De geslachtsverhouding tussen man en vrouw bij ree - op de natuurbrug en in de omgeving - is berekend door het aantal registraties van vrouwen te delen door het aantal registraties van mannen. Voor de natuurbrug zijn hiervoor de geregistreerde passages van een soort gebruikt, zowel die in de natuurzone zonder menselijk medegebruik als natuurzone met menselijk medegebruik, waarbij dubbeltellingen zijn uitgefilterd. Voor de omgeving zijn alleen de registraties gebruikt op dagen dat het hele etmaal is gemeten. In de berekening zijn alleen adulte dieren meegenomen, omdat het geslacht van juveniele dieren in veel gevallen niet kon worden bepaald. Voor $7 \%$ van de adulte dieren - zowel op de natuurbrug als in de omgeving - geldt dat het geslacht niet kon worden bepaald. Deze registraties zijn buiten de analyses gehouden. De steekproefgrootte op de natuurbrug en in de omgeving was voor deze analyse respectievelijk 471 en 278 registraties. De geslachtsverhouding is uitgedrukt in $M: V$. Een Chi-square-test is gebruikt om vast te stellen of een gevonden verschil statistisch significant $(p \leq 0,05)$ is of niet. Hierbij was de nulhypothese dat de geslachtsverhouding op de natuurbrug en in de omgeving niet verschilt.

\subsubsection{Verdeling van passages over het jaar, per geslacht}

In een eerste stap zijn de procentuele verdelingen van het aantal passages van mannelijke en vrouwelijke reeën op de natuurbrug onderling vergeleken. Hiervoor zijn de geregistreerde passages van een soort gebruikt, zowel die in de natuurzone zonder menselijk medegebruik als natuurzone met menselijk medegebruik, waarbij dubbeltellingen zijn uitgefilterd. Een Chi-square-test is gebruikt om vast te stellen of een gevonden verschil tussen de geslachten statistisch significant $(p \leq 0,05)$ is of niet. Hierbij was de nulhypothese dat de proportionele verdeling van de passages over de geslachten op de 
natuurbrug niet verschilt. Eenzelfde analyse is gedaan voor de omgeving. Hiervoor zijn de geregistreerde passages van een soort op de referentieplekken gebruikt, onder voorwaarde dat op de dag van de passage het hele etmaal is gemeten. Ook hier is met behulp van een Chi-square-test getoetst of een gevonden verschil statistisch significant $(p \leq 0,05)$ is of niet. In een tweede stap zijn de procentuele verdelingen van het aantal passages van mannelijke reeën op de natuurbrug en in de omgeving met elkaar vergeleken. Datzelfde is gedaan voor de vrouwelijke reeën. Een Chi-square-test is gebruikt om te onderzoeken of een gevonden verschil statistisch significant $(p \leq 0,05)$ is of niet. Hierbij was de nulhypothese dat de proportionele verdeling van de passages van mannen dan wel vrouwen op de natuurbrug en in de omgeving niet verschilt.

\subsubsection{Leeftijdsverdeling}

Op de natuurbrug zijn van drie soorten ook juveniele dieren waargenomen: ree, bunzing en haas. Op de natuurbrug is 133 maal een reekalf geregistreerd. Eenmaal is een jonge bunzing waargenomen, samen met een adult dier. Jonge hazen zijn slechts tweemaal geregistreerd. Door de lage aantallen voor bunzing en haas blijven deze soorten hier verder buiten de analyses.

De leeftijdsverdeling bij ree - op de natuurbrug en in de omgeving - is berekend door het aantal registraties van juveniele dieren te delen door het aantal registraties van adulten. Voor de natuurbrug zijn hiervoor de geregistreerde passages van een soort gebruikt, zowel die in de natuurzone zonder menselijk medegebruik als natuurzone met menselijk medegebruik, waarbij dubbeltellingen zijn uitgefilterd. Voor de omgeving zijn alleen de registraties gebruikt op dagen dat het hele etmaal is gemeten. Op de natuurbrug en in de omgeving kon voor respectievelijk $4 \%$ en $3 \%$ van de geregistreerde dieren de leeftijd niet worden bepaald. Deze registraties zijn buiten de analyses gehouden. De steekproefgrootte op de natuurbrug en in de omgeving was voor deze analyse respectievelijk 641 en 370 registraties. De leeftijdsverdeling is uitgedrukt in adult:juveniel. Een Chisquare-test is gebruikt om vast te stellen of een gevonden verschil statistisch significant $(p \leq 0,05)$ is of niet. Hierbij was de nulhypothese dat de leeftijdsverdeling op de natuurbrug en in de omgeving niet verschilt.

\subsubsection{Verdeling van passages over het jaar, per leeftijdsgroep}

In een eerste stap zijn de procentuele verdelingen van het aantal passages van adulte en juveniele reeën op de natuurbrug onderling vergeleken. Hiervoor zijn de geregistreerde passages van een soort gebruikt, zowel die in de natuurzone zonder menselijk medegebruik als natuurzone met menselijk medegebruik, waarbij dubbeltellingen zijn uitgefilterd. Een Chi-square-test is gebruikt om vast te stellen of een gevonden verschil tussen de leeftijdsgroepen statistisch significant $(p \leq 0,05)$ is of niet. Hierbij was de nulhypothese dat de proportionele verdeling van de passages over de leeftijdsgroepen op de natuurbrug niet verschilt. Eenzelfde analyse is gedaan voor de omgeving. Hiervoor zijn de geregistreerde passages van een soort op de referentieplekken gebruikt, onder voorwaarde dat op de dag van de passage het hele etmaal is gemeten. Ook hier is met behulp van een Chi-square-test getoetst of een gevonden verschil statistisch significant $(p \leq 0,05)$ is of niet. In een tweede stap zijn de procentuele verdelingen van het aantal passages van adulte reeën op de natuurbrug en in de omgeving met elkaar vergeleken. Datzelfde is gedaan voor de juveniele reeën. Een Chi-square-test is gebruikt om te onderzoeken of een gevonden verschil statistisch significant $(p \leq 0,05)$ is of niet. Hierbij was de nulhypothese dat de proportionele verdeling van de passages van adulte dan wel juveniele dieren op de natuurbrug en in de omgeving niet verschilt.

\subsubsection{Loopwijze}

De procentuele verdeling van de passages van een soort over de loopwijze - op de natuurbrug en in de omgeving - is als volgt berekend: aantal passages per loopwijze / totaal aantal passages * 100.

Voor de natuurbrug zijn hiervoor de geregistreerde passages van een soort gebruikt, zowel die in de natuurzone zonder menselijk medegebruik als natuurzone met menselijk medegebruik, waarbij dubbeltellingen zijn uitgefilterd. Voor de omgeving zijn alleen de registraties gebruikt op dagen dat het hele etmaal is gemeten. Op de natuurbrug en in de omgeving kon voor respectievelijk $1 \%$ en $2 \%$ van 
de geregistreerde dieren geen loopwijze worden bepaald, omdat de dieren niet bewogen op de fotobeelden. Deze registraties zijn buiten de analyses gehouden. De steekproefgrootte, alle soorten samen, op de natuurbrug en in de omgeving was voor deze analyse respectievelijk 1.316 en 1.173 registraties. Een Chi-square-test is gebruikt om vast te stellen of een gevonden verschil statistisch significant $(p \leq 0,05)$ is of niet. Hierbij was de nulhypothese dat de loopwijze op de natuurbrug en in de omgeving niet verschilt.

\subsubsection{Gedrag}

Per gedragsvorm is de proportie van het aantal passages berekend waarin de gedragsvorm is vertoond. Dit is gedaan voor zowel de natuurbrug als de omgeving. De berekening is als volgt gedaan: som van het aantal keer dat een gedragsvorm door de soort is vertoond / som van het totaalaantal van alle door de soort vertoonde gedragsvormen $* 100$. Omdat een dier tijdens een passage meerdere gedragsvormen kan laten zien, betekent dit dus dat de procentuele verdeling van alle gedragsvormen samen $>100 \%$ is. Voor de natuurbrug zijn hiervoor de geregistreerde passages van een soort gebruikt, zowel die in de natuurzone zonder menselijk medegebruik als natuurzone met menselijk medegebruik, waarbij dubbeltellingen zijn uitgefilterd. Voor de omgeving zijn alleen de registraties gebruikt op dagen dat het hele etmaal is gemeten. De steekproefgrootte, alle soorten samen, op de natuurbrug en in de omgeving was voor deze analyse respectievelijk 1.817 en 2.064 registraties. Een Chi-square-test is gebruikt om vast te stellen of een gevonden verschil statistisch significant $(p \leq 0,05)$ is of niet. Hierbij was de nulhypothese dat de gedragsvormen op de natuurbrug en in de omgeving niet verschillen.

\subsubsection{Passagefrequentie Corridor Prinses Julianalaan}

De natuurverbinding is slechts voor een deel (156 dagen) van de onderzoeksperiode gemonitord. Het aantal hier geregistreerde passages van middelgrote zoogdieren is dan ook een onderschatting van het werkelijke aantal dat hier is gepasseerd. Om hiervoor te corrigeren, extrapoleren we het geregistreerde aantal passages per soort naar een jaar, middels: aantal geregistreerde passages / aantal opnamedagen $* 365$. Hierbij geldt de aanname dat het gemiddelde aantal passages voor de opnamedagen representatief is voor het gemiddelde aantal passages op de dagen dat niet is gemonitord. Omdat het zichtveld van de camera in de natuurverbinding slechts de helft van de corridor omvatte, is dit aantal passages vervolgens met twee vermenigvuldigd. Hierbij geldt de aanname dat het gemiddelde aantal passages in de gemonitorde helft representatief is voor het gemiddelde aantal passages in de andere helft van de corridor. De trefkans in de natuurverbinding is op vergelijkbare wijze berekend als voor de natuurbrug (zie paragraaf 3.6.6). Datzelfde geldt voor de stuwingsindex (zie paragraaf 3.6.7).

\subsubsection{Passagefrequentie kleine faunatunnels}

Omdat de onderzoeksperiode precies een jaar was, is het geschatte aantal passages ook direct de passagefrequentie per jaar. De passagefrequenties per dag, week en maand zijn berekend door dit aantal respectievelijk te delen door 365, 52 en 12 .

\subsection{Analysegegevens mens en huisdier}

\subsubsection{Aantal passages op de natuurbrug}

Om het aantal passages van mens en huisdier op de natuurbrug te schatten, zijn dezelfde stappen doorlopen als voor de wilde zoogdieren (zie paragraaf 3.6.2). Om het aantal mensen en huisdieren in de natuurzone zonder menselijk medegebruik te bepalen, zijn eerst alle dubbeltellingen verwijderd en vervolgens de tellingen aangepast met behulp van een correctiefactor op basis van de ijking met de cameraval in de stobbenwal. Tabel 3.10 geeft een overzicht van de berekening van de correctiefactoren voor mens en huisdieren. 
Tabel 3.10 Het aantal passages van mensen en huisdieren in de natuurzone zonder menselijk medegebruik, bepaald op basis van de vier camera's in de palen exclusief dan wel inclusief de fotobeelden van camera STOBBE, het percentage toename in het aantal passages als camera STOBBE is betrokken en de hieruit afgeleide correctiefactor.

\begin{tabular}{lcccc} 
Soort & $\begin{array}{c}\text { Aantal passages } \\
\text { natuurzone zonder } \\
\text { menselijk } \\
\text { medegebruik, excl. } \\
\text { Camera STOBBE }\end{array}$ & $\begin{array}{c}\text { Aantal passages } \\
\text { natuurzone zonder } \\
\text { medegebruik, incl. } \\
\text { Camera STOBBE }\end{array}$ & $\begin{array}{c}\text { Percentage } \\
\text { toename aantal } \\
\text { passages }\end{array}$ \\
Mens & 21 & 22 & 5 & 1,05 \\
\hline Hond & 14 & 14 & 0 & 1,00 \\
\hline Huiskat & 8 & 34 & 325 & 4,25 \\
\hline
\end{tabular}

Om het aantal mensen en huisdieren dat jaarlijks passeert in de recreatiezone te schatten, is eerst een ijking uitgevoerd. Dit is gedaan door een dagdeel (15 juli 2018) passerende mensen door directe observatie te tellen, gelijktijdig met tellingen door camera REC. Voor voetgangers was er geen verschil tussen de directe observaties $(n=8)$ en de camera $(n=8)$. Voor fietsers was het aantal directe observaties $(n=148)$ circa $18 \%$ hoger dan het aantal registraties met de camera $(n=121)$. Ruiters en huisdieren passeerden niet tijdens de ijking. Om voor de gemiste passages van fietsers te corrigeren, is hier de correctiefactor 1,22 gebruikt. Het aantal mensen en huisdieren dat jaarlijks passeert in de natuurzone met menselijk medegebruik is vervolgens geschat volgens: aantal geregistreerde passages / 103 opnamedagen * 365. Hierbij geldt de aanname dat het gemiddelde aantal passages voor de opnamedagen representatief is voor het gemiddelde aantal passages op de dagen dat niet is gemonitord.

In een laatste stap is het geschatte aantal passages in de natuurzone zonder menselijk medegebruik en de natuurzone met menselijk medegebruik bij elkaar opgeteld om het totale aantal passages voor de natuurbrug te berekenen.

\subsubsection{Passagefrequentie op de natuurbrug}

Om de gemiddelde passagefrequentie per dag, week en maand te berekenen is het geschatte aantal passages van mens en huisdier voor een jaar gedeeld door respectievelijk 365, 52 en 12.

Om het gemiddelde aantal passages van mens en huisdier per weekdag te bepalen, zijn alleen de registraties gebruikt die zijn gemaakt tijdens de 103 opnamedagen dat camera REC operationeel was. Hierbij is het aantal fietsers gecorrigeerd op basis van de ijking.

\subsubsection{Procentuele verdeling passages over het etmaal}

De procentuele verdeling van het aantal passages van mensen over het etmaal is berekend op basis van zowel de registraties die in de natuurzone met menselijk medegebruik zijn gedaan (103 meetdagen) en die in de natuurzone zonder menselijk medegebruik zijn gedaan (365 meetdagen). Dubbeltellingen in laatstgenoemde zone zijn uitgefilterd. Registraties van leden van ons onderzoeksteam in deze zone zijn buiten beschouwing gelaten.

\subsubsection{Procentuele verdeling illegale passages over het jaar}

Voor mensen is de procentuele verdeling van het aantal passages over het jaar berekend op basis van de registraties die in de natuurzone zonder menselijk medegebruik zijn gedaan. Wat illegaal gebruik betreft, gaat de aandacht hier dus alleen uit naar illegale betreding van de natuurzone zonder menselijk medegebruik. Illegaal gebruik van de natuurzone met menselijk medegebruik is niet meegenomen. Voor huisdieren is de procentuele verdeling van het aantal passages over het jaar berekend op basis van de registraties die in beide zones zijn gedaan. Dubbeltellingen in de natuurzone zonder menselijk medegebruik zijn uitgefilterd. Registraties van leden van ons onderzoeksteam in deze zone zijn in de berekeningen voor mensen buiten beschouwing gelaten. 


\subsubsection{Procentuele verdeling illegale passages over het etmaal}

Voor mensen is de procentuele verdeling van het aantal passages over het etmaal berekend op basis van de registraties die in de natuurzone zonder menselijk medegebruik zijn gedaan. Voor huisdieren is de procentuele verdeling van het aantal passages over het jaar berekend op basis van de registraties die in beide zones zijn gedaan. Dubbeltellingen in de natuurzone zonder menselijk medegebruik zijn uitgefilterd. Registraties van leden van ons onderzoeksteam in deze zone zijn in de berekeningen voor mensen buiten beschouwing gelaten.

\subsubsection{Vergelijking aantal illegale passages natuurbrug versus omgeving}

Om het aantal illegale passages van mensen en huisdieren op de natuurbrug te kunnen vergelijken met het aantal in de omgeving, is een vergelijkbare werkwijze gevolgd als voor de wilde zoogdieren (zie paragraaf 3.6.6). Allereerst is het aantal passages per jaar voor iedere referentieplek gestandaardiseerd naar de functionele breedte van de natuurbrug op basis van de detectieafstand van de soort (mens, $15 \mathrm{~m}$; hond en huiskat, 7,5 m). Vervolgens is het gemiddelde aantal passages per jaar in de omgeving berekend door het gemiddelde te nemen over alle referentieplekken.

\subsection{Analyse effect menselijk medegebruik natuurbrug}

Een eventueel effect van het menselijk medegebruik van de natuurbrug op het gebruik door middelgrote zoogdieren is in vier stappen verkend:

\section{Stap 1: Correlatieanalyse}

De correlatieanalyse is een techniek om de correlatie - of samenhang - tussen twee variabelen vast te stellen. In dit geval onderzoeken we de correlatie tussen het aantal mensen dat de natuurbrug op een dag is gepasseerd en twee variabelen die gerelateerd zijn aan het gebruik door zoogdieren: (1) het aantal passages en (2) het tijdstip waarop de dieren passeren. Dit doen we per soort en voor alle soorten samen. Wat betreft het aantal passages verkennen we twee subsets van de verzamelde data: (a) aantal passages tussen 12:00 en 24:00 uur en (b) aantal passages tussen 12:00 en 12:00 uur de volgende dag. Wat betreft het tijdstip verkennen we alleen de subset met passages tussen 12:00 en 24:00 uur. De correlaties zijn berekend op basis van Pearson's Correlation Coëfficiënt (r), waarbij een t-test is gebruikt om te testen of een correlatie significant is of niet. Gevonden correlaties zijn als volgt gekwalificeerd: $r=0,0-0,2=$ zeer zwak; $r=0,2-0,4=$ zwak; $r=0,4-0,7=$ matig; $r=0,7-0,9=$ sterk; $r=0,9-1,0=$ zeer sterk.

In de analyse zijn 125 meetdagen gebruikt. Dit betreft allereerst de 103 meetdagen waarop de natuurzone met menselijk medegebruik is gemonitord binnen de onderzoeksperiode van 1 juli 2018 tot 30 juni 2019. Daarnaast zijn 22 meetdagen gebruikt uit de testfase van de camera's (in juni 2018). Op deze manier kon de steekproef enigszins worden vergroot. Voor mensen geldt dat passages - legaal dan wel illegaal - in zowel de natuurzone zonder menselijk medegebruik als de natuurzone met menselijk medegebruik in de analyse zijn meegenomen. Voor fietsers is de op basis van de ijking verkregen correctiefactor toegepast. Voor de zoogdieren geldt dat passages in beide zones in de analyse zijn meegenomen. De op basis van de ijking verkregen correctiefactoren zijn toegepast. Dubbeltellingen zijn uitgefilterd.

De correlatieanalyse kon alleen voor ree, vos en haas worden uitgevoerd. Boommarter, bunzing en eekhoorn zijn niet gepasseerd op de hier gebruikte meetdagen. Das is wel gepasseerd, maar in slechts zeer beperkte aantallen, drie- en zevenmaal in het tijdvak 12:00-24:00 respectievelijk 12:00-12:00. Een correlatieanalyse is ook uitgevoerd voor alle middelgrote zoogdieren samen die zijn gepasseerd, dus ree, vos, das en haas.

\section{Stap 2: Lineaire regressie}

Als er een sterke correlatie is tussen het aantal mensen en het aantal zoogdieren dan wel het tijdstip van passeren van de zoogdieren dan kan, als het aantal passerende mensen bekend is, een voorspelling worden gedaan over het gebruik door zoogdieren. Om na te gaan hoe groot de 
voorspellende waarde is van eventuele in de correlatieanalyse gevonden verbanden, is een trendanalyse uitgevoerd met behulp van lineaire regressie. Hierbij is getoetst of de gemiddelde verandering in het aantal passerende dieren dan wel in het tijdstip waarop de dieren passeren, significant $(p \leq 0,05)$ afwijkt van nul. Dit is alleen gedaan voor soorten waarvoor minimaal een $z w a k k e$, significante correlatie is gevonden.

\section{Stap 3: Drukke versus rustige dagen}

Een dataset met veel 'gemiddelde waarnemingen', dus waarnemingen die niet aan de uiteinden van het spectrum van de variabelen zitten, kunnen een eventueel verband tussen de variabelen camoufleren. Een causaal verband is dan met lineaire regressie niet altijd vast te stellen, terwijl het er wellicht wel is. Daarom is verkend of er een significant verschil is in het aantal zoogdieren dan wel het tijdstip van passeren van de zoogdieren tussen dagen dat er relatief veel mensen zijn gepasseerd ('drukke dagen') en dagen dat er relatief weinig mensen zijn gepasseerd ('rustige dagen'). Drukke dagen zijn hier gedefinieerd als dagen waarop > 250 mensen passeerden. Rustige dagen zijn hier gedefinieerd als dagen waarop $<100$ mensen passeerden. Deze analyse is alleen gedaan voor soorten waarvoor minimaal een zwakke, significante correlatie is gevonden. Een two-sample t-test is gebruikt om vast te stellen of een gevonden verschil statistisch significant $(p \leq 0,05)$ is of niet. Hierbij was de nulhypothese dat het gemiddelde aantal zoogdieren dat passeert dan wel het gemiddelde tijdstip waarop de dieren passeren op drukke en rustige dagen niet verschilt.

\section{Stap 4: Verkenning verband met daglengte}

Het kan zo zijn dat met het korter worden van de dagen in het najaar, het aantal mensen dat de brug gebruikt evenredig afneemt. In dat geval is het gebruik door mensen mogelijk gecorreleerd aan daglengte en kan een verband tussen het gebruik door zoogdieren en het aantal mensen wellicht (mede) veroorzaakt zijn door veranderingen in daglengte. Om de aanwezigheid van een dergelijk effect te verkennen, is een correlatieanalyse uitgevoerd - middels de Pearson's Correlation Coëfficiënt - tussen het aantal passages van mensen op een dag en de daglengte.

\subsection{Kanttekeningen bij de methoden}

De monitoring van natuurbruggen is in het verleden vooral uitgevoerd met behulp van sporenbedden, i.e. zandbedden die de hele breedte van de brug bestrijken en waarin met regelmaat de sporen van passerende dieren worden afgelezen. Sinds de opkomst van (betaalbare) infraroodcamera's heeft nu het gebruik van cameravallen echter de voorkeur. Het gebruik van cameravallen voor de monitoring van faunapassages kent veel voordelen ten opzichte van het gebruik van sporenbedden. Met cameravallen kan namelijk veel extra informatie van passerende dieren worden verzameld die met behulp van sporenbedden niet of slechts beperkt kan worden verkregen. Bijvoorbeeld het tijdstip van passeren, de groepsgrootte, het geslacht en leeftijd van het dier, het gedrag tijdens het passeren of eventuele unieke kenmerken van individuele dieren. Ook zijn cameravallen minder gevoelig voor de weersomstandigheden dan sporenbedden en zorgen ze voor minder aan het onderzoek gerelateerde verstoring, omdat onderzoekers de cameravallen slechts incidenteel hoeven te bezoeken voor het uitlezen van de fotobeelden en vervangen van batterijen. Sporenbedden daarentegen worden bij voorkeur dagelijks afgelezen of enkele malen per week.

Cameravallen hebben echter ook beperkingen. Een eerste is dat de camera's soms niet worden geactiveerd, terwijl er wel een dier passeert. De ijking die is uitgevoerd met de cameraval in de stobbenwal illustreert dit (zie Tabel 3.6). In absolute aantallen hebben de vier cameravallen NO, NW, ZO en ZW 116 passerende dieren - alle soorten samen - gemist die de cameraval in de stobbenwal wel heeft geregistreerd. Dit betekent dat de vier camera's samen bijna $20 \%$ van de passerende dieren hebben gemist. Procentueel zijn er grote verschillen tussen de soorten, waarbij een relatief kleine soort (haas) het vaakst is gemist. Omdat we hier met correctiefactoren - op basis van de ijking hebben gerekend, is voor deze gemiste dieren gecorrigeerd. Ook de cameraval in de stobbenwal kan echter dieren hebben gemist. Temeer omdat deze cameraval niet op de voorkeurshoogte (0,5-0,6 m boven maaiveld) kon worden geïnstalleerd. Dit kan betekenen dat we hier het werkelijke aantal passages nog steeds onderschatten, vooral van de kleinere soorten, i.e. alle soorten kleiner dan das of vos. 
Dat de cameravallen passerende dieren missen, komt ook tot uiting als we de registraties van het camerapaar NO/NW vergelijken met die van het camerapaar ZO/ZW. Deze twee cameraparen bestreken beide de volledige breedte van de natuurzone zonder menselijk medegebruik. De cameraparen zouden dus min of meer vergelijkbare registraties van passerende dieren/mensen moeten opleveren. Dat is echter niet het geval. Camerapaar NO/NW is tijdens de onderzoeksperiode 507 maal geactiveerd. Hierbij zijn eventuele dubbeltellingen - gelijktijdige activering van zowel camera NO als NW - uitgefilterd. Camerapaar ZO/ZW is 833 maal geactiveerd, exclusief dubbeltellingen. De cameraparen zijn echter slechts 452 maal gelijktijdig geactiveerd. Dit betekent dat camerapaar NO/NW 38\% van de door het op het zuiden gerichte camerapaar geregistreerde passages - van een of meer dieren/ mensen - heeft gemist. En camerapaar ZO/ZW heeft 9\% van de passages gemist die wel door camerapaar NO/NW zijn geregistreerd. Dit betekent dat het aantal passages met circa $37 \%$ of $5 \%$ zou zijn onderschat als alleen het camerapaar NO/NW respectievelijk ZO/ZW zou zijn geïnstalleerd.

Er zijn geen aanwijzingen dat de gekozen onderzoeksmethode - het gebruik van cameravallen, inclusief de palen waarin deze zijn geïnstalleerd - een negatief effect heeft gehad op het gebruik van de natuurbrug dan wel de omgeving door middelgrote zoogdieren. Er zijn geen schrikreacties geregistreerd als gevolg van een camera. In de meeste gevallen negeren de dieren de camera's. In sommige gevallen worden ze aangetrokken tot de camera's en inspecteren ze deze van dichtbij om daarna hun weg te vervolgen.

Camera ZW heeft tijdens de onderzoeksperiode aanmerkelijk meer zoogdieren geregistreerd dan de overige drie camera's in de palen. Camera ZW registreerde 947 passerende zoogdieren, tegenover 195, 408 en 178 registraties door respectievelijk camera ZO, NW en NO. Een deel van dit verschil is wellicht te verklaren door het gedrag van de dieren. Deze passeren de brug wellicht bij voorkeur aan de westkant van genoemde zone, waardoor ze wel door camera ZW en niet door camera ZO worden geregistreerd. Het circa tweemaal hogere aantal registraties door camera NW ten opzichte van NO ondersteunt deze verklaring. Het aantal registraties van camera ZW is echter nog eens ruim tweemaal hoger dan die van camera NW. Dit verschil hangt naar verwachting samen met de hoek waarin de camera's gepositioneerd waren. De richthoek van de camera's was in principe 60 graden. Camera ZW is echter, per abuis, vanaf 17 november 2018 in een hoek van circa 45 graden gepositioneerd. Deze camera stond vanaf toen dus meer naar de grond gericht. Dit leverde aanmerkelijk meer registraties op van passerende dieren, inclusief de kleinere soorten. Zo is camera ZW de enige camera van de vier in de palen geïnstalleerde camera's die de boommarter, bunzing en eekhoorn heeft geregistreerd. Daarnaast is het aantal registraties van das, vos en haas ook aanzienlijk hoger dan die van de andere camera's. Vanaf de start van het onderzoek tot genoemde datum registreerden de camera's NW en ZW min of meer gelijke aantallen passerende dieren, respectievelijk 179 en 175 . Na die datum was het aantal registraties door camera ZW ruim driemaal zo hoog, 772 tegenover 229 door camera NW.

Een ander aspect waarmee rekening moet worden gehouden, is de reactietijd van de cameraval, dus de tijd die verstrijkt tussen het moment dat de warmte-/bewegingssensor wordt geactiveerd en de eerst opname. De in dit onderzoek gebruikte camera's behoren wat reactietijd betreft $-0,1$ tot 0,2 sec - tot de snelste cameravallen die beschikbaar zijn op de markt. Desalniettemin kunnen dieren gemist worden als ze in hoge snelheid passeren. Onze gegevens laten dat ook zien. Over de gehele onderzoeksperiode zijn er door de camera's NO, NW, ZO en ZW 5.357 series van tien fotobeelden genomen waarop geen dier (of mens) te zien is. Het merendeel daarvan (96\%) betreft beelden die bij daglicht zijn gemaakt. Deze 'lege' beelden bij daglicht zijn naar verwachting voor een relatief klein deel het gevolg van passerende middelgrote zoogdieren. Een groter deel hangt naar verwachting samen met langs vliegende vogels die de camera's activeren. Het grootste deel lijkt echter een gevolg van de weersomstandigheden. Op sommige dagen met felle zonneschijn en wind hebben de camera's min of meer continu foto's genomen, soms uren achtereen. Dit hangt waarschijnlijk samen met een relatief groot verschil in temperatuur tussen door de zon beschenen en beschaduwde delen van de brug, in combinatie met door de wind bewegende struiken. In de schemering en nacht doet dit probleem zich niet voor. Een analyse van de 'lege' series van fotobeelden die tijdens de schemering of in het donker zijn genomen, kan dan ook enig inzicht geven in de mate waarin passages van dieren worden gemist omdat ze te snel uit beeld zijn. Tijdens de onderzoeksperiode zijn in de schemering en nacht 320 series van foto's genomen zonder een dier of mens in beeld. Het betreft hier alleen series 
die door de camera's NO, NW, ZO of ZW zijn gemaakt. Door vergelijking van het tijdstip waarop een lege serie is gemaakt met het tijdstip van series met passerende dieren die door de andere drie camera's zijn gemaakt, kunnen we vaststellen dat 109 (34\%) van de lege series vrijwel zeker betrekking hebben op een dier dat is gepasseerd. Voor de overige 211 lege series is dat niet met zekerheid te zeggen, maar is dit wel waarschijnlijk. Als we de dubbeltellingen - lege series die door twee of meer camera's op hetzelfde tijdstip zijn genomen - eruit filteren $(n=9)$, houden we 202 lege series over. Als we aannemen dat deze alle een passerend dier betreffen, dan betekent dit dat we hier het totaalaantal passages van middelgrote zoogdieren - alle soorten samen - met circa $17 \%$ onderschatten.

We vergelijken de metingen op de natuurbrug met metingen in de omgeving. In het onderzoek zijn daarvoor twaalf willekeurige referentieplekken aangewezen, waar passages van middelgrote zoogdieren met een cameraval zijn gemonitord. Deze referentieplekken zijn binnen een gebied met een straal van $2 \mathrm{~km}$ vanaf de natuurbrug gepositioneerd. Dit betekent dat er circa één cameraval per 100 ha is opgesteld. In de analyses van de passagefrequentie nemen we, per soort, het gemiddelde van deze referentieplekken of het gemiddelde van een selectie van deze plekken. De op deze wijze verkregen gemiddelde waarden zijn bij voorkeur min of meer 'stabiel', i.e. veranderen niet sterk meer als er een referentieplek wordt toegevoegd. Figuur 24 geeft de cumulatieve gemiddelden van het aantal passages per soort, waarbij de waarde van $\mathrm{O} 1$ als startpunt is genomen en in de berekening van het gemiddelde vervolgens steeds een referentieplek is toegevoegd. Referentieplekken die niet binnen voor de soort geschikt leefgebied liggen, zijn niet meegenomen in de berekening. Het cumulatieve gemiddelde van de meeste soorten is min of meer stabiel vanaf 01-09. Dat geldt niet voor ree en konijn. Het cumulatieve gemiddelde van deze soorten vertoont tussen 01-09 en 01-012 een dalende trend. Dit is een gevolg van grote variatie in het aantal passages tussen de referentieplekken. Zo zijn er voor ree en konijn plekken waar geen dieren zijn geregistreerd, maar ook plekken waar 146 (ree) of 277 (konijn) maal een passage van de betreffende soort is waargenomen. Dit betekent dat er voor deze soorten beter op een groter aantal referentieplekken gemeten had kunnen worden. Het betekent ook dat de gemiddelde passagefrequenties van deze soorten die voor de omgeving zijn berekend en de daaruit afgeleide stuwingsindexen, met enige voorzichtigheid moeten worden gehanteerd.

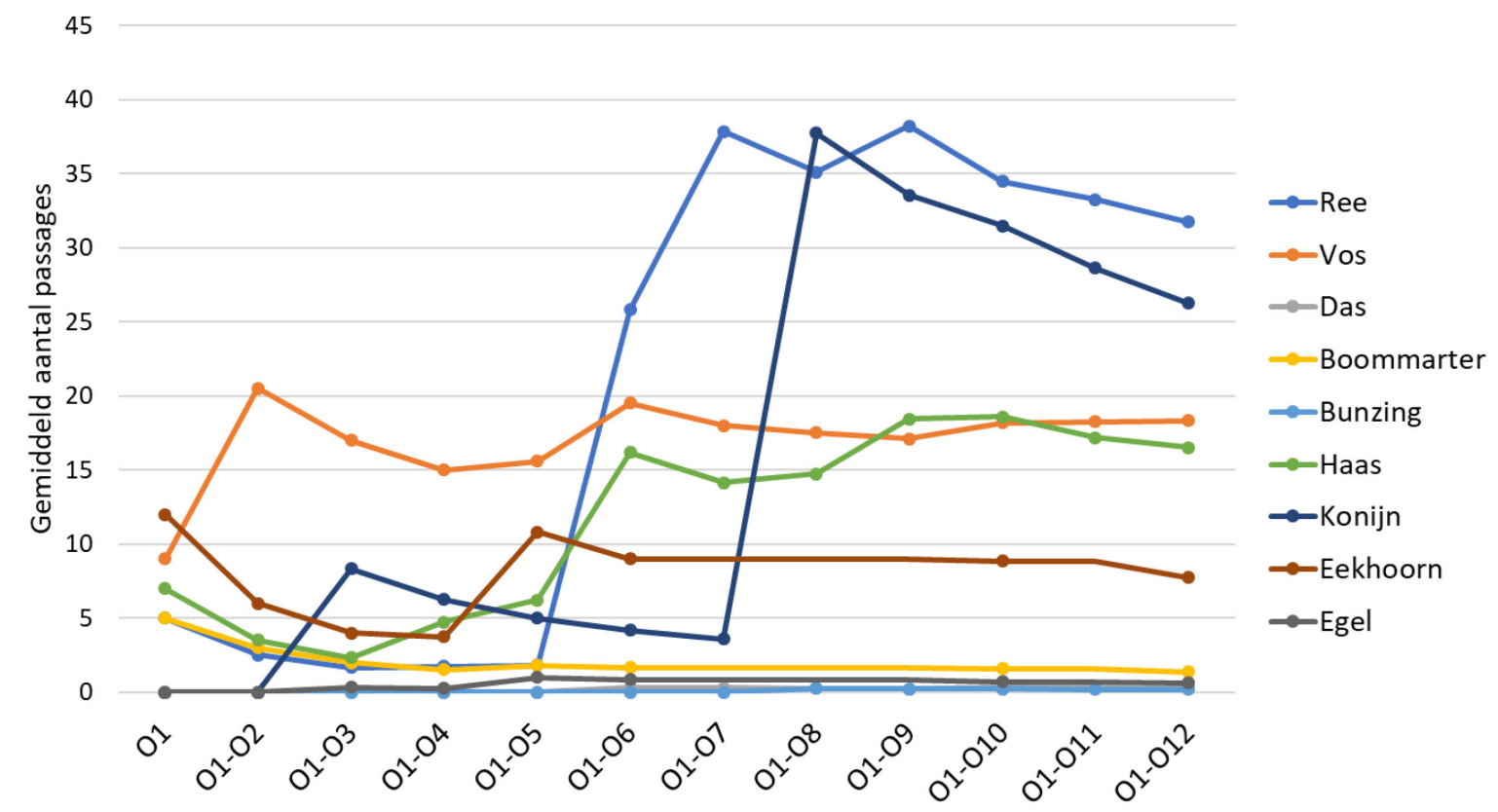

Figuur 24 Cumulatief gemiddelde van het aantal passages per zoogdiersoort voor de twaalf referentieplekken in de omgeving van Natuurbrug Laarderhoogt. 


\section{$4 \quad$ Gebruik natuurbrug door middelgrote zoogdieren}

\subsection{Inleiding}

In dit hoofdstuk beschrijven we het gebruik van de natuurbrug door middelgrote zoogdieren. De aandacht gaat hierbij uit naar soortensamenstelling, frequentie van passage, verdeling van de passages over het jaar, het tijdstip van passeren, de manier van lopen tijdens passeren, vertoond gedrag tijdens passeren en de geslachtsverhouding en leeftijdsverdeling binnen soorten. We zetten dit gebruik steeds af tegen de activiteit die we op de referentieplekken hebben gemeten. Vervolgens evalueren we of dit gebruik van de natuurbrug overeenkomt met de gestelde doelen zoals beschreven in paragraaf 3.3.

\subsection{Soorten}

Tijdens het onderzoek is het gebruik van de natuurbrug door zeven middelgrote zoogdieren vastgesteld. Hiertoe behoren de drie doelsoorten - ree, das en boommarter - maar ook vos, bunzing, haas en eekhoorn (Figuur 25-31). In totaal zijn er op de natuurbrug 1.333 passages van middelgrote zoogdieren - door een of meerdere camera's - geregistreerd. In slechts vier gevallen $(0,30 \%)$ kon de soort niet worden bepaald.

Op de referentieplekken in de omgeving zijn negen soorten middelgrote zoogdieren waargenomen (Tabel 4.1). Behalve de soorten die op de natuurbrug zijn geregistreerd, zijn hier ook konijn en egel waargenomen. Er zijn wel grote verschillen tussen plekken. Terwijl de vos op alle referentieplekken is waargenomen en ree en haas op tien plekken, zijn bunzing, das en egel op slechts één of twee plekken geregistreerd.

Tabel 4.1 Waargenomen middelgrote zoogdieren per referentieplek. Tevens is aangegeven of de referentieplek in bos $(B)$ dan wel heide $(H)$ was gesitueerd.

\begin{tabular}{|c|c|c|c|c|c|c|c|c|c|c|c|c|c|}
\hline \multirow[t]{2}{*}{ Diersoort } & 01 & 02 & 03 & 04 & 05 & 06 & 07 & 08 & 09 & 010 & 011 & 012 & Aantal \\
\hline & B & B & B & B & B & B & $\mathrm{H}$ & $\mathrm{H}$ & $\mathrm{H}$ & B & $\mathrm{H}$ & B & plekken \\
\hline Ree & & & & & & & & & & & & & 10 \\
\hline Das & & & & & & & & & & & & & 2 \\
\hline Boommarter & & & & & & & & & & & & & 5 \\
\hline Haas & & & & & & & & & & & & & 10 \\
\hline Konijn & & & & & & & & & & & & & 3 \\
\hline Eekhoorn & & & & & & & & & & & & & 4 \\
\hline Egel & & & & & & & & & & & & & 2 \\
\hline
\end{tabular}

In de omgeving zijn ree, vos, das, boommarter, haas, konijn en eekhoorn zowel op plekken ten noorden als ten zuiden van de natuurbrug geregistreerd. De bunzing is alleen aan de zuidzijde, op de Westerheide waargenomen. De egel is alleen aan de noordzijde waargenomen, in het bos van de Blaricummerheide en in het Crailose Bos. 

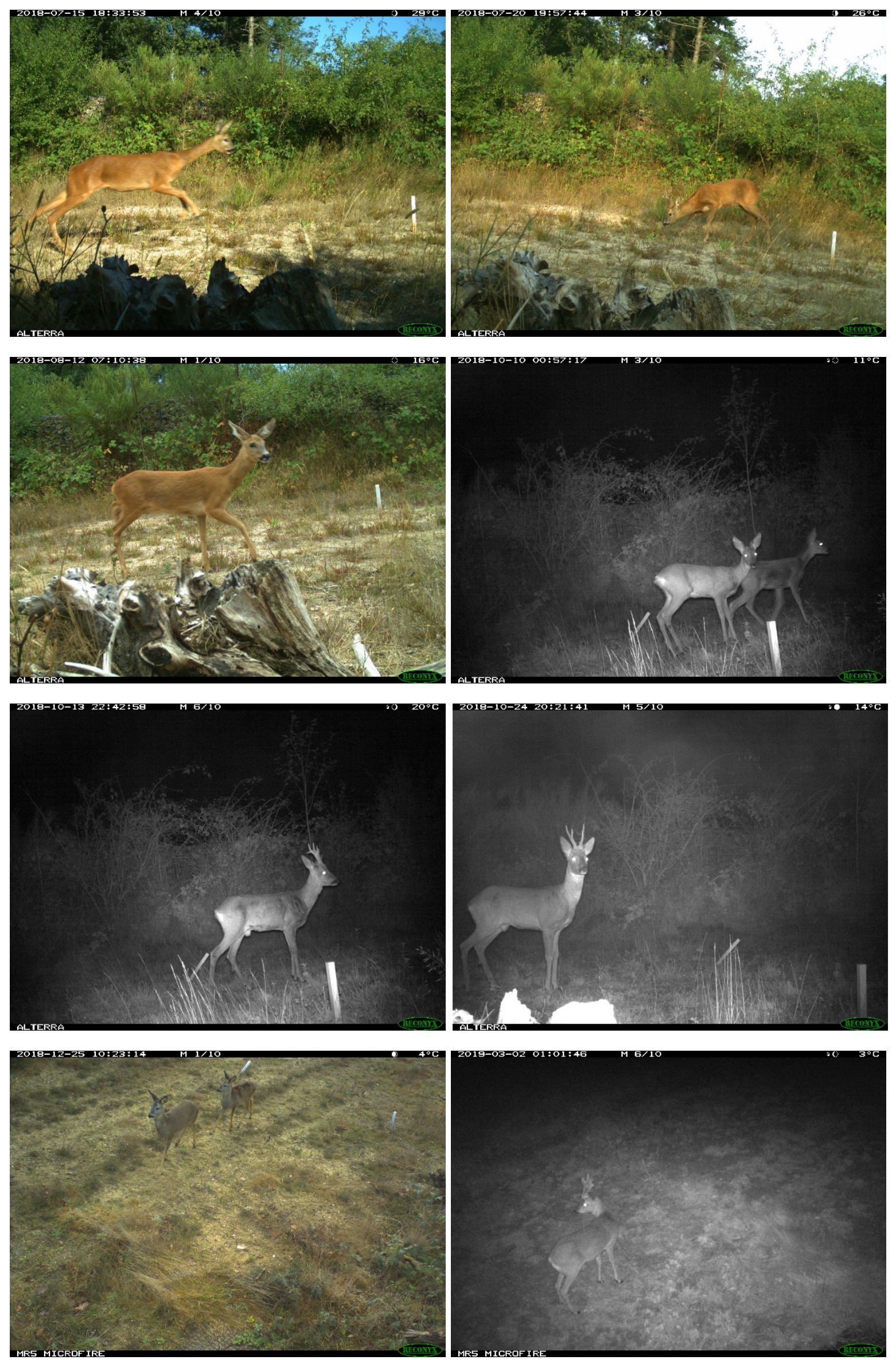

Figuur 25 Fotobeelden van reeën die de natuurbrug passeren. 

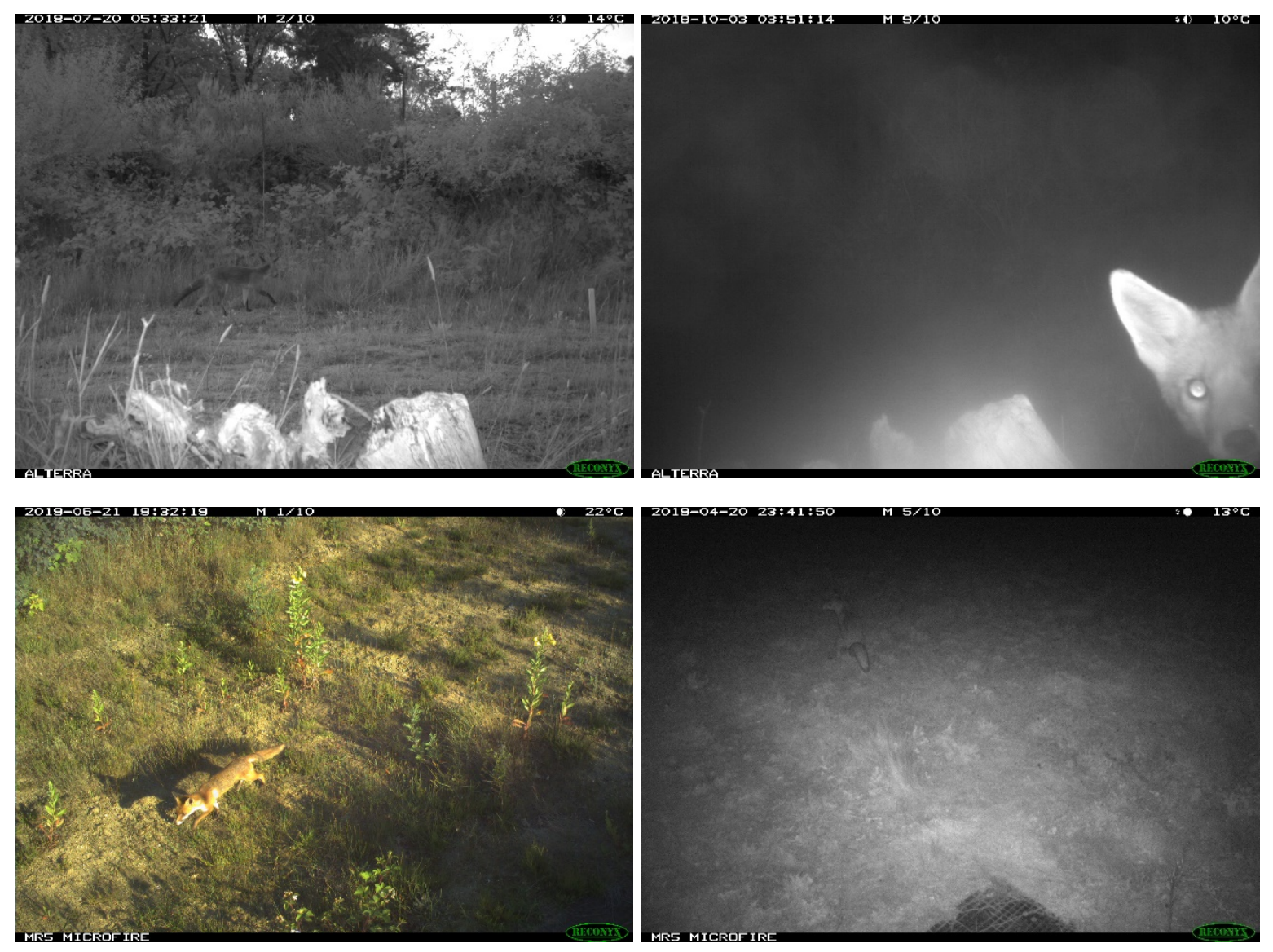

Figuur 26 Fotobeelden van vossen die de natuurbrug passeren.
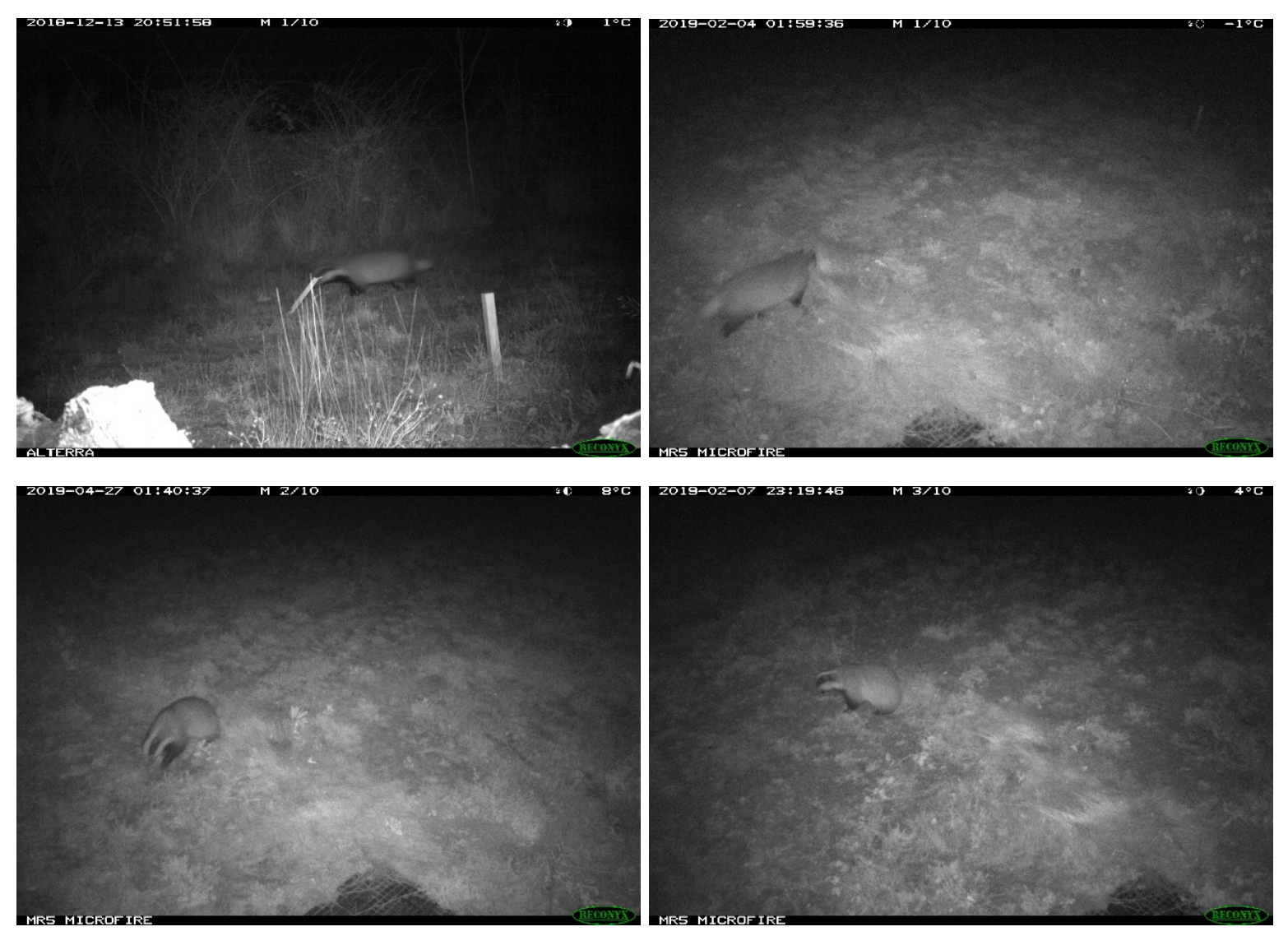

Figuur 27 Fotobeelden van dassen die de natuurbrug passeren. 


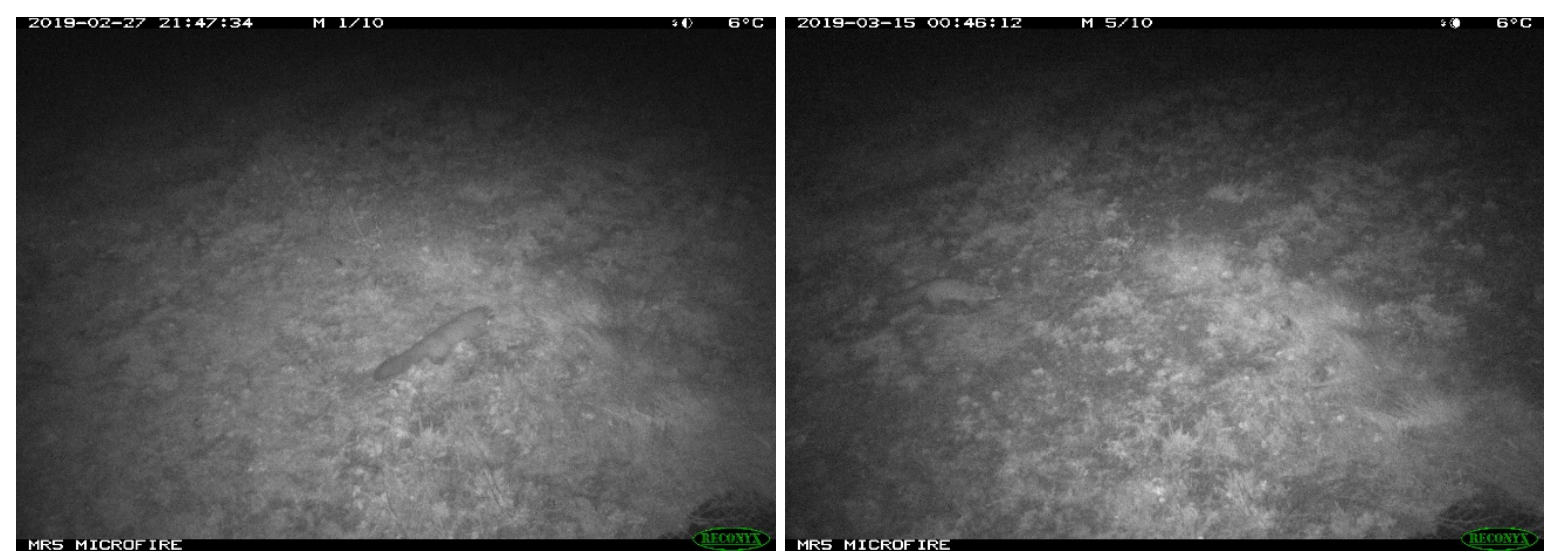

Figuur 28 Fotobeelden van boommarters die de natuurbrug passeren.

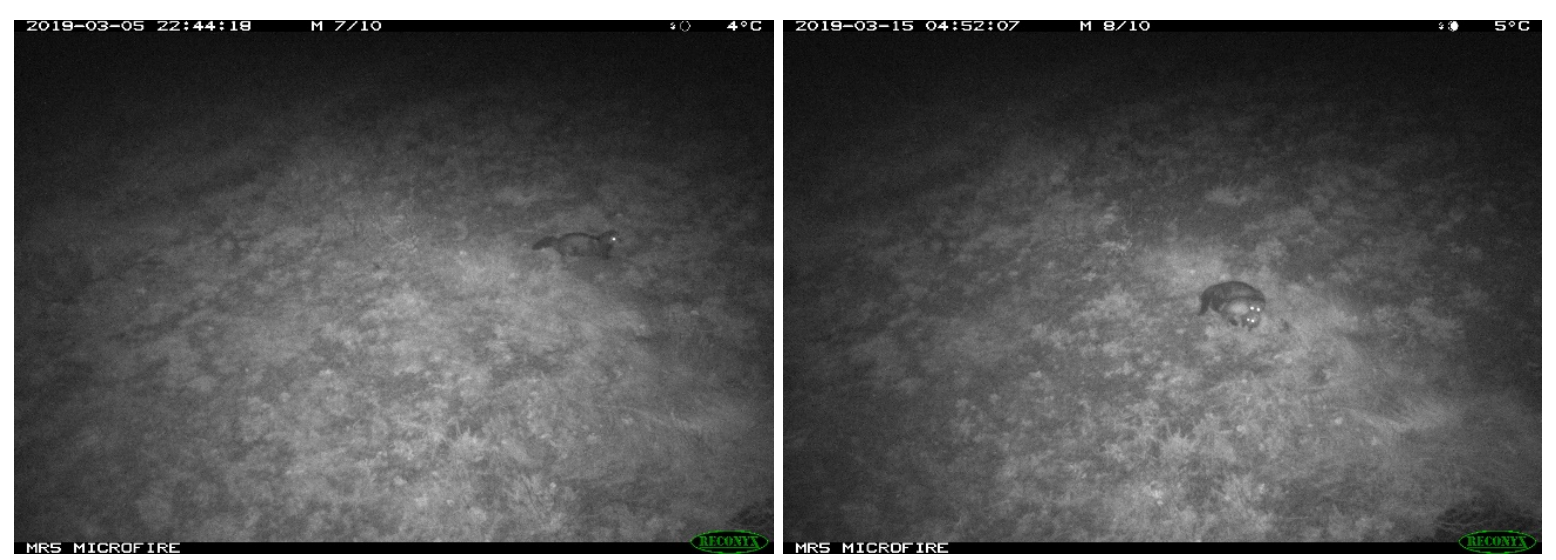

Figuur 29 Fotobeelden van bunzingen die de natuurbrug passeren. Rechts een adult met jong.
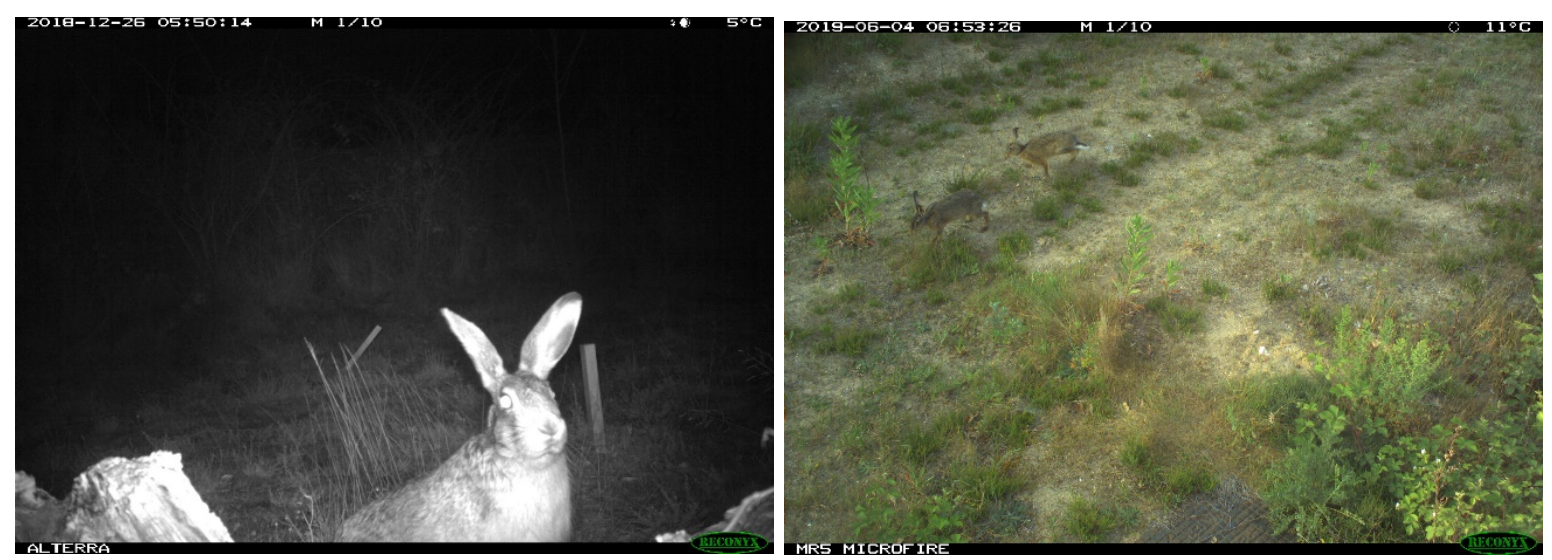

Figuur 30 Fotobeelden van hazen die de natuurbrug passeren.
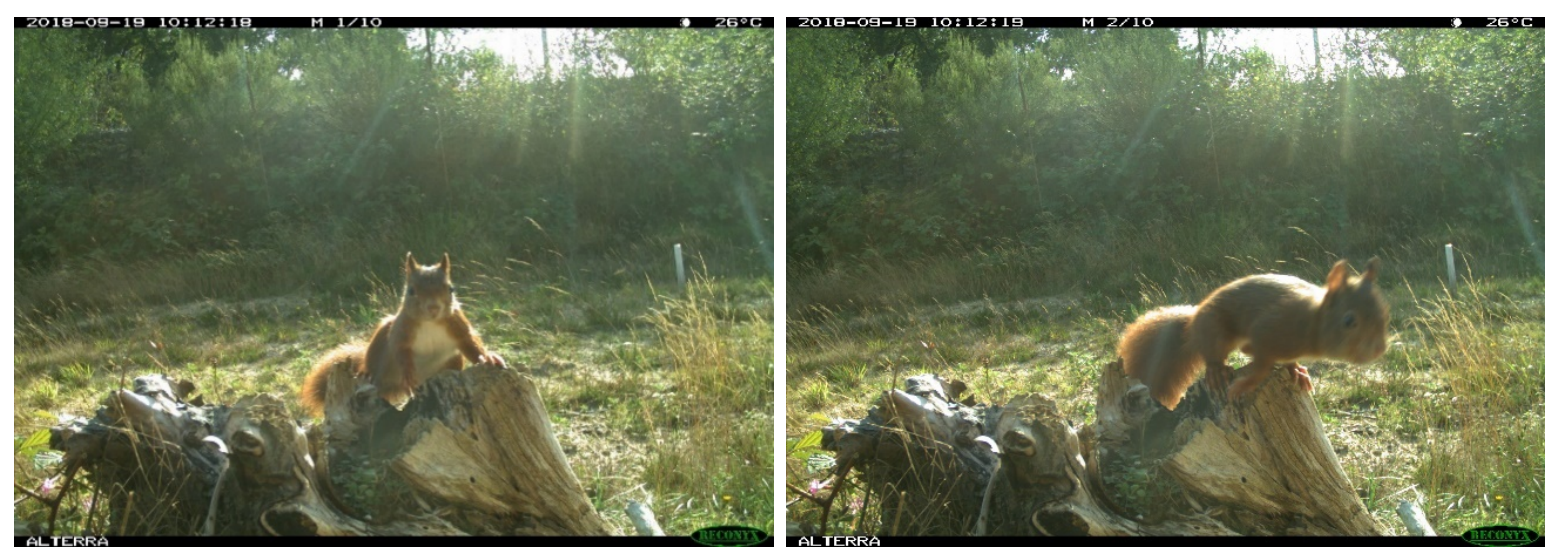

Figuur 31 Een eekhoorn passeert de natuurbrug via de stobbenwal. 


\subsection{Frequentie van passeren}

Het totaal aantal passages van middelgrote zoogdieren tijdens de onderzoeksperiode is geschat op 1.974 dieren (Tabel 4.2). Dit betekent dat er gemiddeld 5-6 dieren per dag passeren, circa 40 per week en circa 164 per maand. Er zijn echter grote verschillen tussen soorten. Van de drie doelsoorten passeert ree het frequentst, gemiddeld bijna tweemaal per dag. Das en boommarter passeren gemiddeld minder frequent, respectievelijk eenmaal per week en eenmaal per tien weken. Van de overige soorten passeren vos en haas frequent, gemiddeld een- tot tweemaal per dag. De bunzing passeert incidenteel, respectievelijk eenmaal in de twee tot drie weken. De eekhoorn passeert zeer incidenteel, gemiddeld eenmaal per tien maanden.

Tabel 4.2 Het geschatte aantal passages in de onderzoeksperiode per soort en voor alle soorten samen, en de gemiddelde passagefrequenties per dag, week en maand.

\begin{tabular}{lllll} 
Soort & $\begin{array}{l}\text { Schatting aantal } \\
\text { passages in } \\
\text { onderzoeksperiode }\end{array}$ & $\begin{array}{l}\text { Gemiddelde aantal } \\
\text { passages/dag }\end{array}$ & $\begin{array}{l}\text { Gemiddelde aantal } \\
\text { passages/week }\end{array}$ & $\begin{array}{l}\text { Gemiddelde aantal } \\
\text { passages/maand }\end{array}$ \\
\hline Ree & 711 & 1,9 & 13,7 & 59,3 \\
\hline Vos & 510 & 1,4 & 9,8 & 42,5 \\
\hline Das & 56 & 0,2 & 1,1 & 4,7 \\
\hline Boommarter & 6 & 0,0 & 0,1 & 0,5 \\
\hline Bunzing & 19 & 0,1 & 0,4 & 1,6 \\
\hline Konijn & 669 & 1,8 & 12,9 & 55,8 \\
\hline Eekhoorn & $\mathbf{2}$ & 0,0 & 0,0 & 0,0 \\
\hline Egel & 0 & 0,0 & 0,0 & 0,1 \\
\hline Alle soorten & $\mathbf{1 . 9 7 4}$ & 0,0 & 0,0 & 0,0 \\
\hline
\end{tabular}

Voor alle soorten samen geldt dat $96 \%$ van de passages kan worden geclassificeerd als een bevestigde oversteek (Figuur 32). Dit betekent dat voor deze dieren een duidelijke noord-zuid- of zuid-noord-beweging over de natuurbrug is geregistreerd. Voor ree, vos en das geldt dat nagenoeg alle passages een bevestigde oversteek zijn. Voor boommarter en bunzing ligt dit percentage lager respectievelijk 57 en $79 \%$-, maar deze cijfers zijn minder robuust, omdat het aantal waarnemingen van deze soorten beperkt was. Ook voor haas, die wel frequent passeerde, ligt dit percentage lager $(87 \%)$. Deze soort is relatief vaker foeragerend aangetroffen, waarbij de dieren geen oversteek maakten. De passages van de eekhoorn zijn voor $100 \%$ geclassificeerd als een bevestigde oversteek, maar ook dit cijfer is niet robuust, omdat het slechts twee waarnemingen betreft.

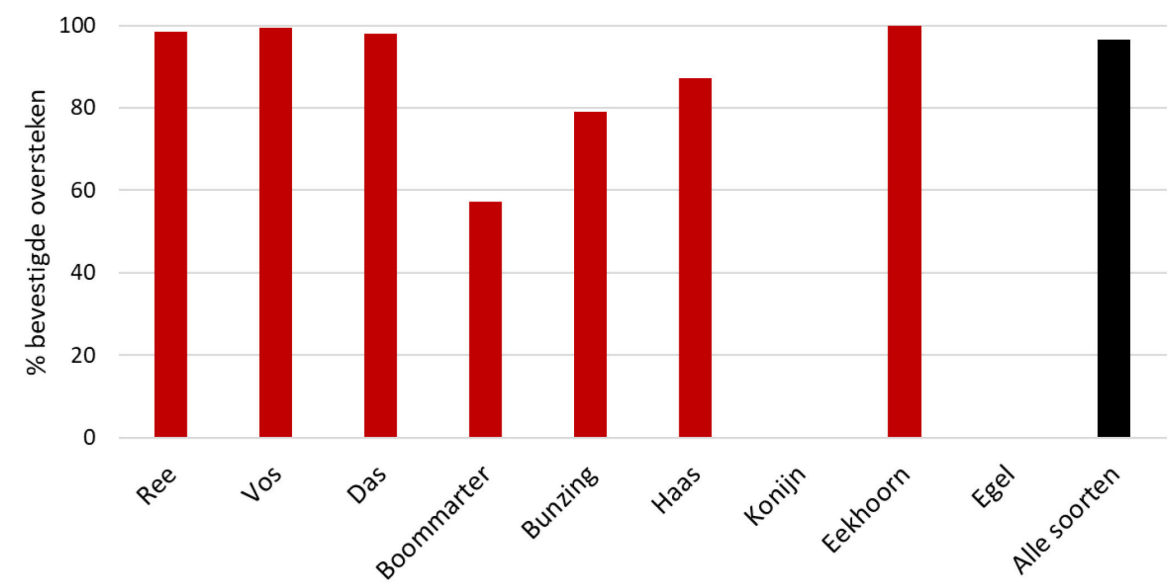

Figuur 32 Het percentage van de geregistreerde passages die als bevestigde oversteek zijn geclassificeerd, per soort en voor alle soorten samen. 


\subsection{Trefkans}

Er zijn grote verschillen in trefkans tussen de soorten (Figuur 33). De doelsoorten ree, das en boommarter hebben een trefkans van respectievelijk 57, 12 en 2\%. Ree heeft daarmee de hoogste trefkans van alle op de natuurbrug geregistreerde soorten. Voor de overige soorten geldt dat de vos een relatief hoge trefkans heeft (55\%), gevolgd door haas (28\%). Bunzing en eekhoorn hebben een trefkans van minder dan $5 \%$.

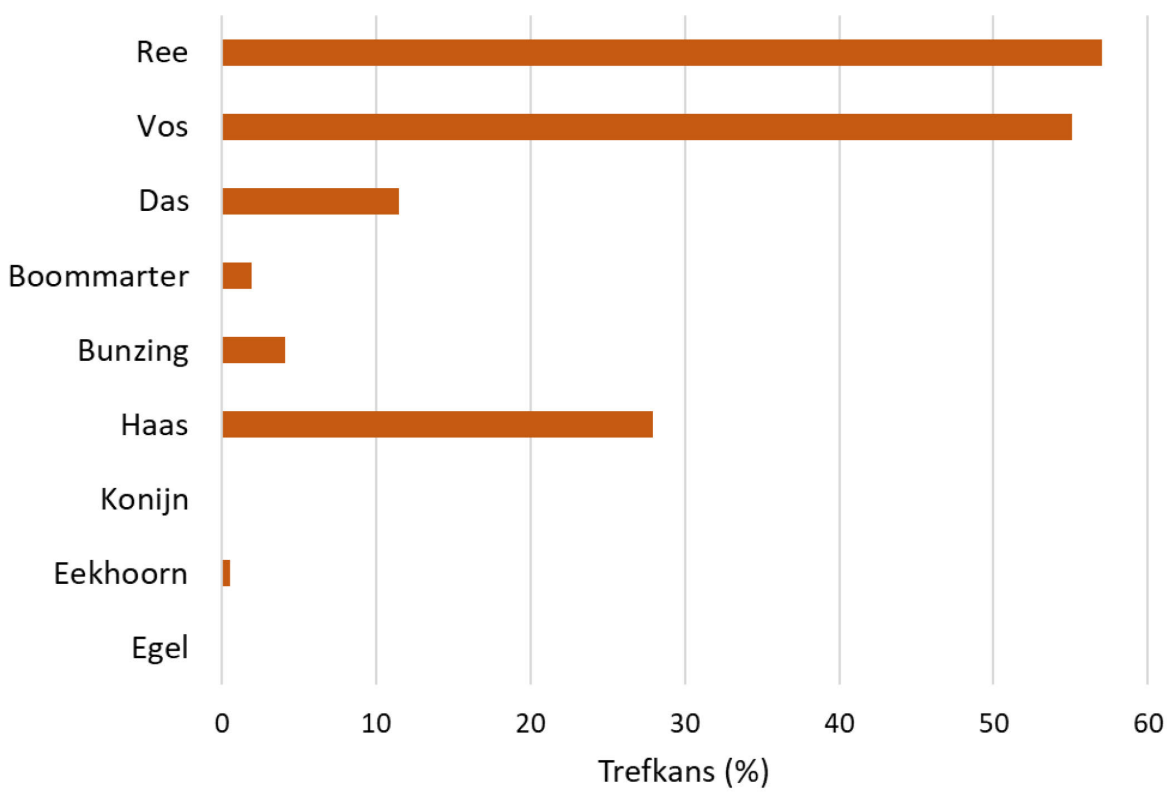

Figuur 33 Trefkans van de soorten op Natuurbrug Laarderhoogt.

\subsection{Passagefrequentie natuurbrug versus omgeving}

\section{Doelsoorten}

De passagefrequenties op de natuurbrug van de doelsoorten ree, das en boommarter zijn alle groter dan de gemiddelde passagefrequenties op de referentieplekken binnen voor deze soorten geschikte biotopen (Figuur 34). Voor deze soorten is er dus sprake van stuwing. Voor de boommarter is deze zeer gering, met een SI van 1,2. Voor ree is deze sterk, met een SI van 9. Voor das is sprake van een zeer sterke stuwing met een SI van bijna 70. Voor de doelsoorten neemt de mate van stuwing af als de passagefrequenties op de natuurbrug worden gerelateerd aan die op referentieplekken die niet alleen binnen voor de soort geschikte biotopen liggen, maar waar de soort tijdens het onderzoek ook is waargenomen. Voor ree en das daalt de SI naar respectievelijk 7 en 12. Voor boommarter is dan zelfs sprake van (lichte) vermijding van de natuurbrug, met een SI van -1,3.

\section{Overige soorten}

Ook voor vos, bunzing en haas is sprake van stuwing, met respectievelijk een SI van 7, 18 en 12 . De eekhoorn - de soort die slechts tweemaal op de natuurbrug is geregistreerd - is de enige soort waar sprake is van vermijding, met een SI van -38. Als de passagefrequenties op de natuurbrug worden gerelateerd aan die op referentieplekken waar de soort tijdens het onderzoek ook is waargenomen, is er voor de vos geen verandering; deze soort is immers op alle referentieplekken waargenomen. De SI van bunzing en haas zakken naar respectievelijk 2 en 10 . Het beeld voor de eekhoorn wordt versterkt, de SI zakt naar -76 . 
Alle referentieplekken binnen geschikt biotoop

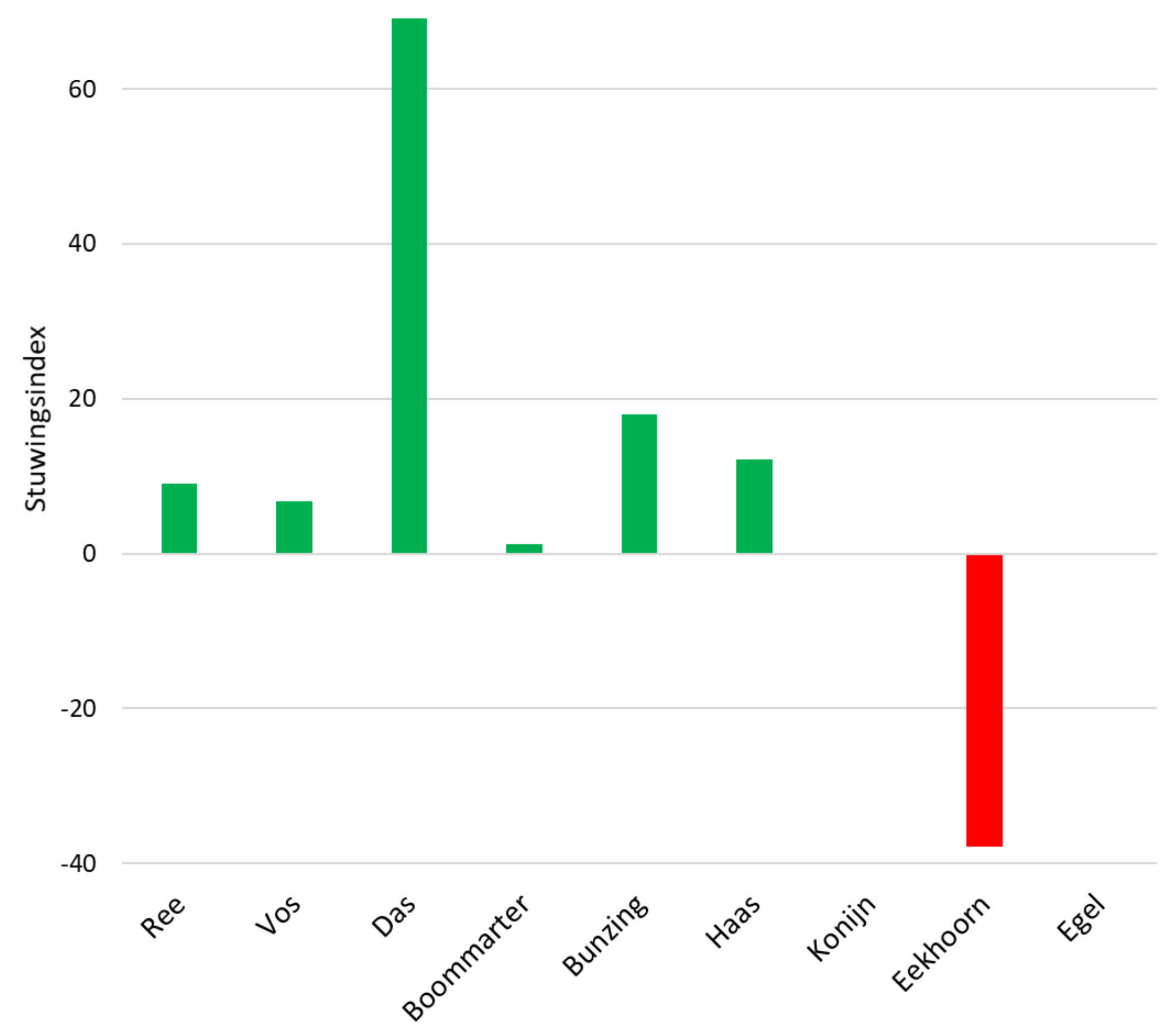

Alleen referentieplekken binnen geschikt biotoop waar de soort is aangetroffen

20

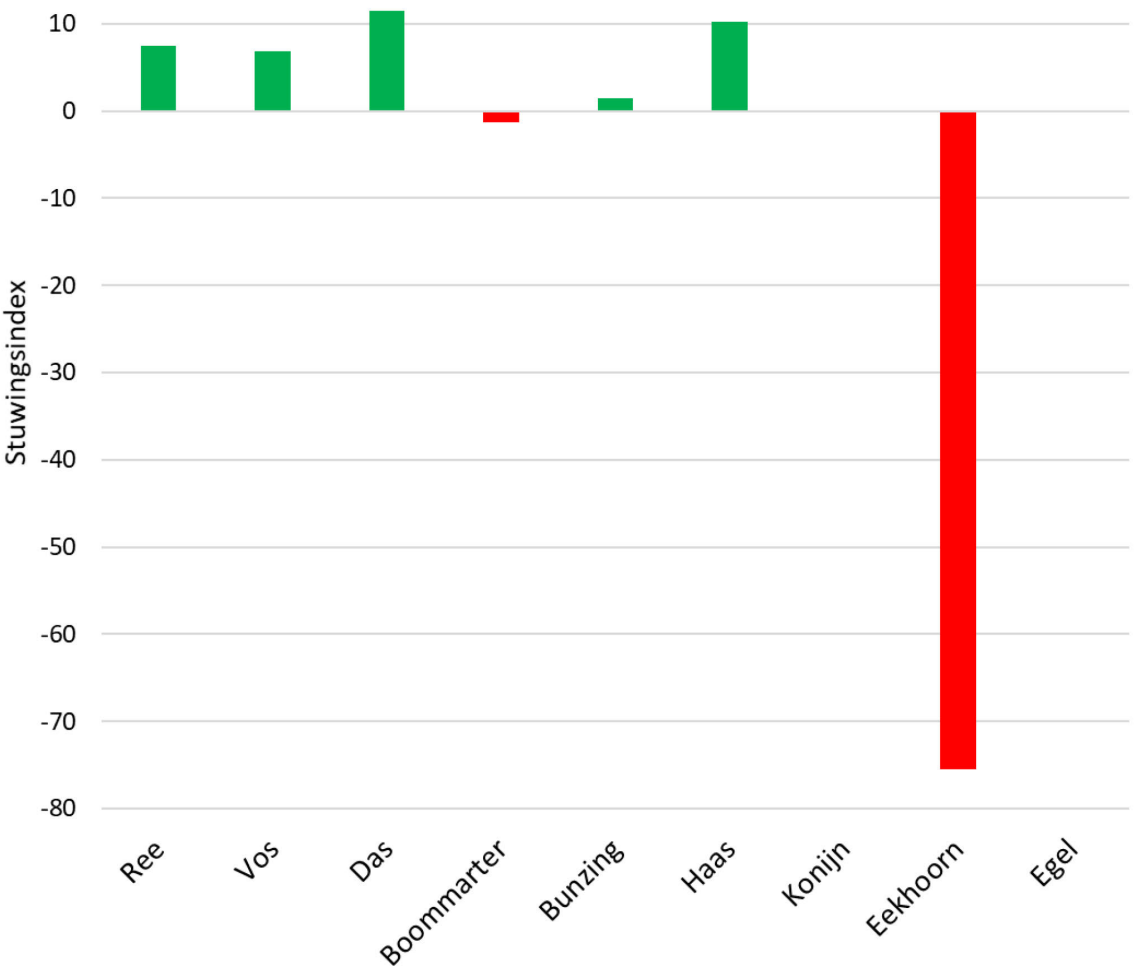

Figuur 34 Stuwingsindex voor de soorten die gebruikmaken van Natuurbrug Laarderhoogt, op basis van de gemiddelde passagefrequentie op alle referentieplekken binnen voor de soort geschikte biotoop (boven) en op referentieplekken binnen voor de soort geschikte biotoop, waar de soort ook is aangetroffen (onder). 


\subsection{Verdeling passages over het jaar}

\section{Doelsoorten}

Wat de doelsoorten betreft is alleen voor ree een goede vergelijking te maken, aangezien deze soort in relatief hoge aantallen is geregistreerd, zowel op de natuurbrug als in de omgeving. Voor ree zien we dat de procentuele verdeling van de passages op de natuurbrug in grote lijnen overeenkomt met die in de omgeving (Figuur 35). In september en oktober waren er relatief weinig passages op de natuurbrug in vergelijking met de referentieplekken. In december, februari en maart is de natuurbrug juist relatief vaker gepasseerd. Deze verschillen zijn voldoende groot om te spreken van een significant verschil in de procentuele verdeling van passages over het jaar op de natuurbrug en in de omgeving $\left(x^{2}=35,4 ; d f=11 ; p<0,001\right)$.

\section{Overige soorten}

Voor de overige soorten is een goed (statistisch) vergelijk alleen mogelijk voor vos en haas. De overige soorten zijn - op de natuurbrug, in de omgeving of op beide plekken - in te lage aantallen aangetroffen. Voor zowel vos $\left(x^{2}=25,1 ; d f=11 ; p<0,01\right)$ als haas $\left(x^{2}=95,1 ; d f=11 ; p<0,001\right)$ is er een significant verschil in de procentuele verdeling van het aantal passages over het jaar tussen natuurbrug en omgeving. Voor vos zien we relatief weinig passages op de natuurbrug in de eerste zeven maanden van het onderzoek in vergelijking met de omgeving. In de laatste periode van het onderzoek verandert dit beeld met relatief veel passages op de natuurbrug. In juli 2019 vond maar liefst $18 \%$ van alle passages van vos plaats. Voor haas zien we hetzelfde beeld met relatief weinig passages op de natuurbrug in de eerst acht maanden van het onderzoek, gevolgd door een periode met relatief veel passages. De verschillen zijn voor haas echter wat groter. 

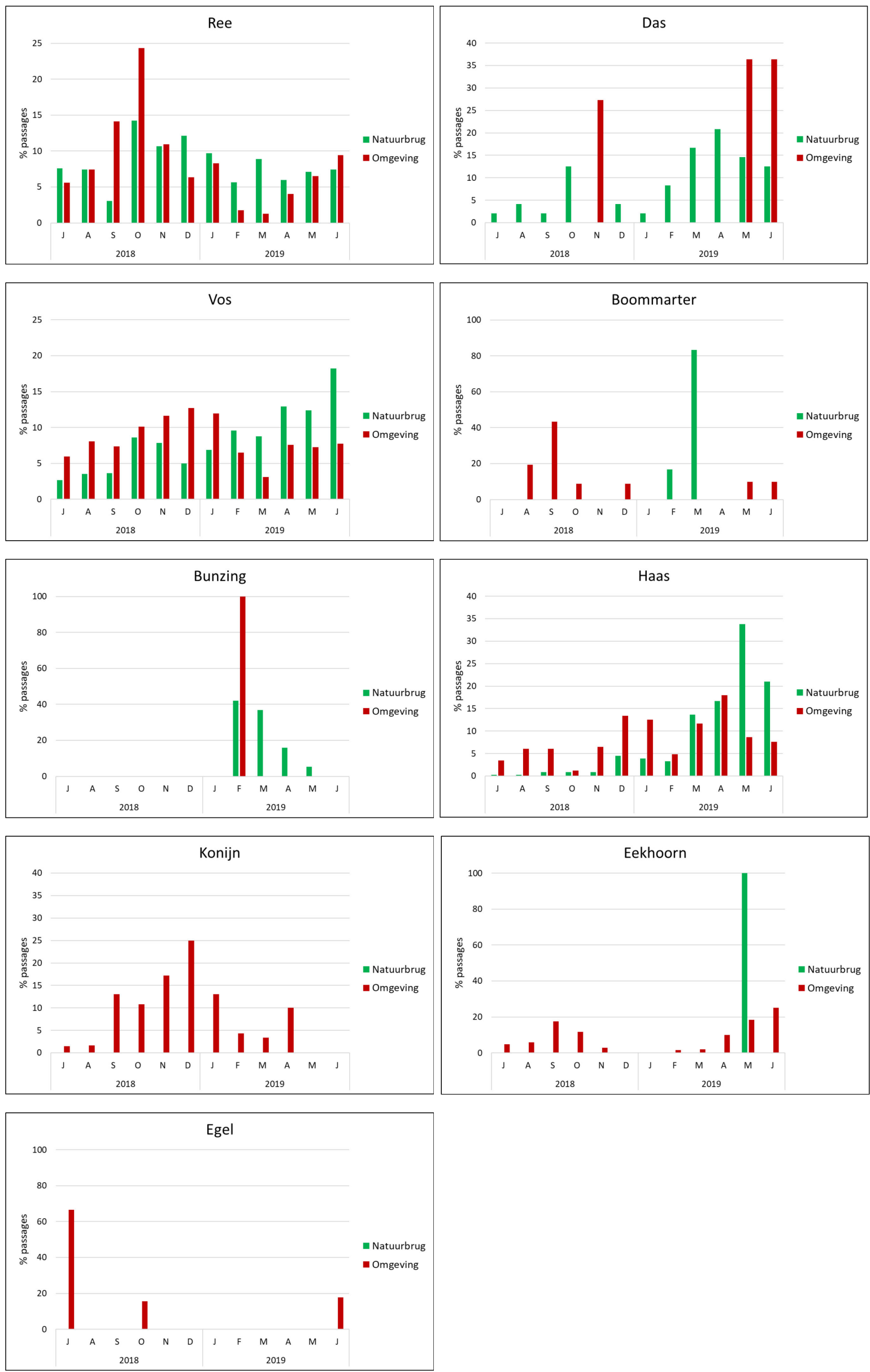

Figuur 35 Per soort de procentuele verdeling van het aantal passages over het jaar voor zowel de natuurbrug als de omgeving. 


\subsection{Verdeling passages over het etmaal}

\section{Doelsoorten}

Voor ree zien we dat de procentuele verdeling van de passages op de natuurbrug over het etmaal significant verschilt van die in de omgeving $\left(x^{2}=196,3 ; d f=23 ; p<0,001\right)$. In de omgeving zijn relatief veel passages in de ochtend waargenomen (7:00-9:00 uur), zien we dat de dieren ook gedurende de dag een zekere activiteit laten zien en is er sprake van een piek in passages tussen 20:00 en 21:00 uur (Figuur 36). Voor de natuurbrug is het beeld anders. In de ochtend tussen 7:00 en 9:00 uur zijn er relatief weinig passages en dit neemt verder af gedurende de dag. Tussen 18:00 en 19:00 uur is er een toename in het aantal passages te zien, maar het grootste deel van de passages vindt pas plaats tussen 22:00 uur en 5:00 uur. 25\% van alle passages heeft plaatsgevonden in de twee uren na middernacht.

De das is in de omgeving slechts driemaal geregistreerd. Het activiteitenpatroon gedurende het etmaal is daarom niet robuust; een extra waarneming verandert het beeld onmiddellijk. Het beeld voor de natuurbrug is robuuster, omdat de procentuele verdeling hier gebaseerd is op 50 passages. In de omgeving zijn alle passages van de das in de tweede helft van de nacht geregistreerd. Voor de natuur-brug geldt ook dat er meer activiteit is na middernacht: $86 \%$ van de passages vond plaats tussen 0:00 en 6:00 uur. Het aantal geregistreerde passages is voor de boommarter zowel in de omgeving als op de natuurbrug zeer beperkt. Ook hier geldt dan ook dat het activiteitenpatroon gedurende het etmaal niet robuust is. In de omgeving vond het merendeel van de passages in de tweede helft van de nacht plaats. Op de natuurbrug was het aantal passages voor en na middernacht bijna gelijk.

\section{Overige soorten}

Voor vos zien we dat de procentuele verdeling van de passages op de natuurbrug over het etmaal significant verschilt van die in de omgeving $\left(x^{2}=64,9 ; d f=19 ; p<0,001\right)$. De vos laat gedurende de dag - vanaf 8:00 uur - nauwelijks activiteit zien. Dit geldt voor zowel de omgeving als de natuurbrug. In de omgeving wordt de soort vanaf circa 16:00 uur actief. Relatief de meeste activiteit is hier gemeten tussen 21:00 en 23:00 uur. In de tweede helft van de nacht blijft de soort actief, maar vanaf circa 6:00 uur neemt het aantal passages snel af. Op de natuurbrug wordt de soort later actief, vanaf circa 21:00 uur. Relatief de meeste passages vinden dan ook plaats in de tweede helft van de nacht. Net als in de omgeving neemt het aantal passages vanaf circa 6:00 uur snel af. Voor de bunzing geldt hetzelfde als voor de das. Voor deze soort is in de omgeving slechts één passage waargenomen, dus een statistische vergelijking van het activiteitenpatroon tussen omgeving en natuurbrug is niet mogelijk. Voor de negentien waarnemingen die van deze soort op de natuurbrug zijn gedaan, geldt dat deze min of meer gelijk verdeeld waren over het eerste en tweede deel van de nacht. De bunzing laat op de natuurbrug een piek in activiteit zien tussen 22:00 en 23:00 uur.

Voor haas zien we dat de procentuele verdeling van de passages op de natuurbrug over het etmaal significant verschilt van die in de omgeving $\left(x^{2}=31,9 ; d f=20 ; p<0,05\right)$. In de omgeving laat de haas in de ochtend - tussen circa 6:00 en 8:00 uur - een piek in het aantal passages zien. Na 8:00 uur neemt dit af, maar de soort passeert ook gedurende de dag nog in lage aantallen. Een tweede piek is te zien in de vroege avond (17:00-18:00 uur), waarna de activiteit gedurende de rest van de avond en nacht min of meer stabiel is. Ook op de natuurbrug laat de haas in de ochtend een piek in activiteit zien, maar hier begint deze al een uur eerder (5:00-8:00 uur). Na 8:00 uur neemt het aantal passages af en gedurende de dag is de soort niet op de natuurbrug aanwezig. In de avond is de soort enkele uren later actief, vanaf circa 19:00 uur, in vergelijking met de omgeving. De activiteit op de natuurbrug is in de tweede helft van de nacht ruim $10 \%$ hoger in vergelijking met de eerste helft van de nacht.

De eekhoorn is slechts tweemaal op de natuurbrug waargenomen. Een vergelijking van het activiteitenpatroon tussen omgeving en natuurbrug is dan ook niet mogelijk. Een van de registraties op de natuurbrug vond plaats gedurende de dag, de andere in het eerste deel van de nacht. Voor de waarnemingen die van deze soort in de omgeving zijn gedaan, geldt dat het merendeel hiervan (71\%) gedurende de dag is gedaan. De overige passages vonden vooral in het eerste deel van de nacht plaats (24\%). Tussen 0:00 en 5:00 zijn in de omgeving geen passages geregistreerd. Pas na 5:00 is er weer activiteit, met een lichte piek tussen 7:00-8:00 uur. 
Konijn en egel zijn alleen in de omgeving geregistreerd. Passages van konijn zijn incidenteel vanaf 17:00 uur gedaan, maar nemen pas na 19:00 uur in aantal toe, met een piek tussen 21:00-

22:00 uur. Na 4:00 uur neemt de activiteit snel af; na 6:00 uur is geen activiteit meer geregistreerd. De verdeling over de eerste en tweede helft van de nacht is min of meer gelijk. Het aantal geregistreerde passages van egel is zeer beperkt, waardoor geen robuust beeld wordt verkregen van het activiteitenpatroon van deze soort. De waarnemingen zijn alle tussen 22:00 en 7:00 uur gedaan. Het merendeel van de passages vond plaats in de tweede helft van de nacht.
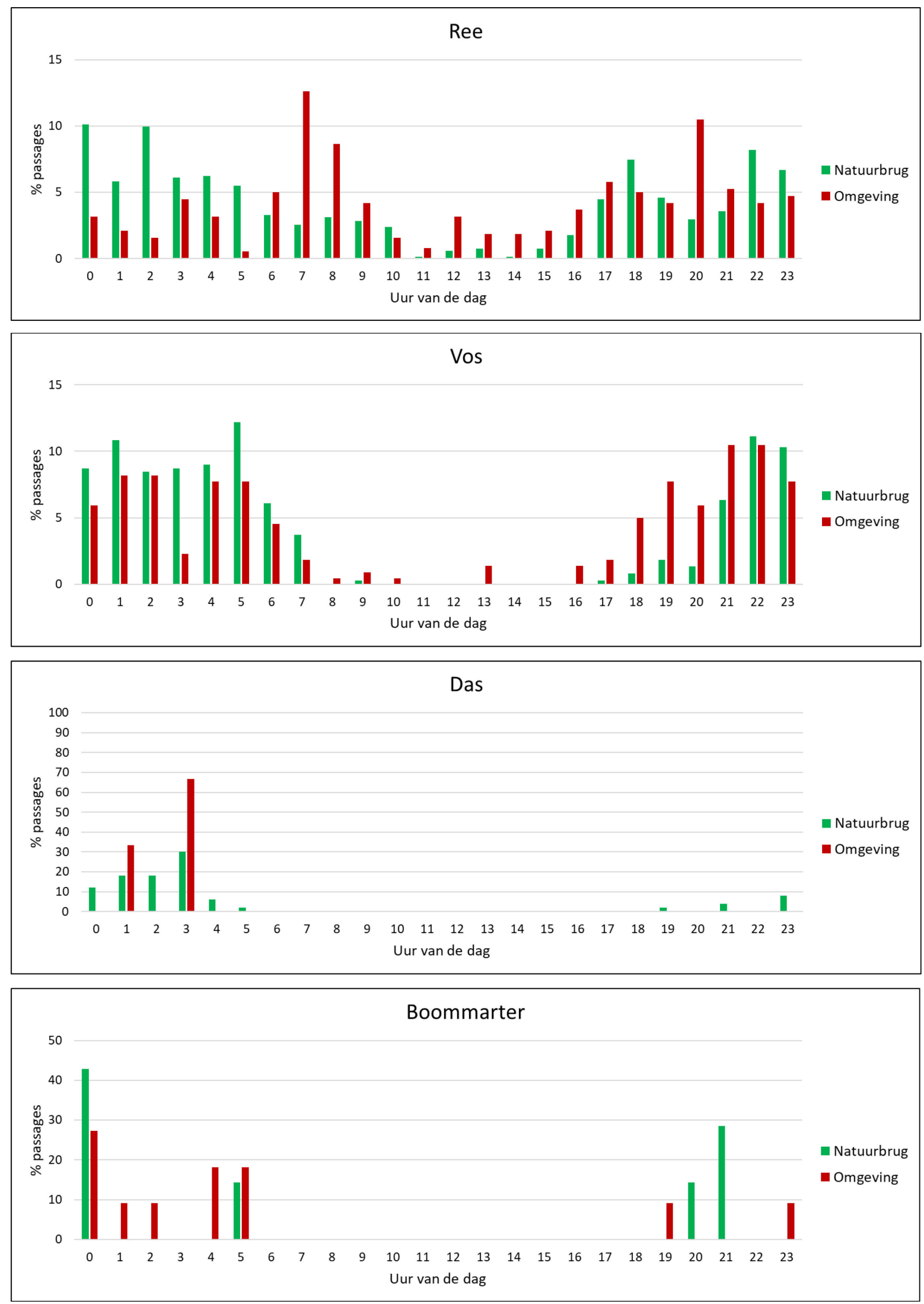

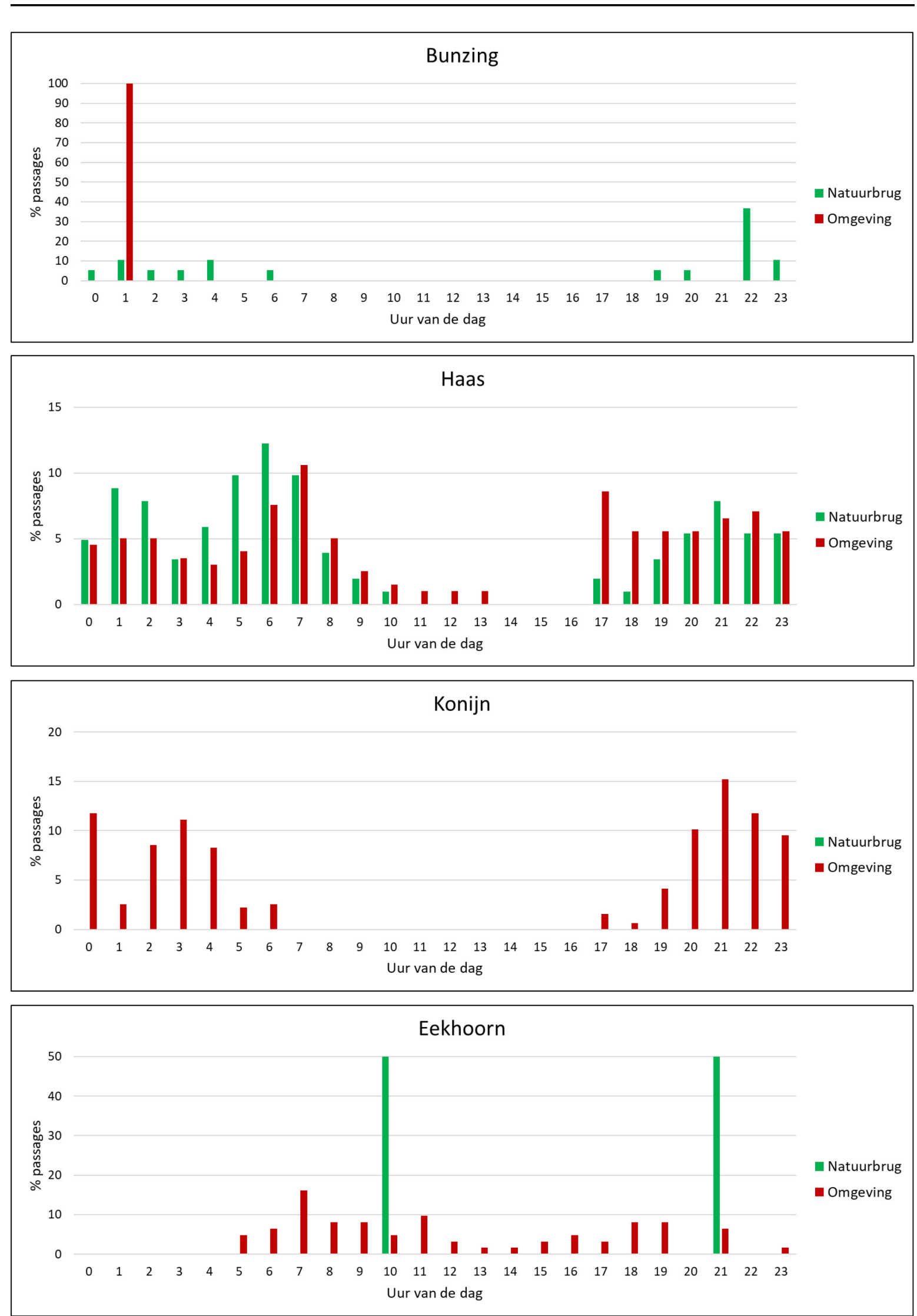


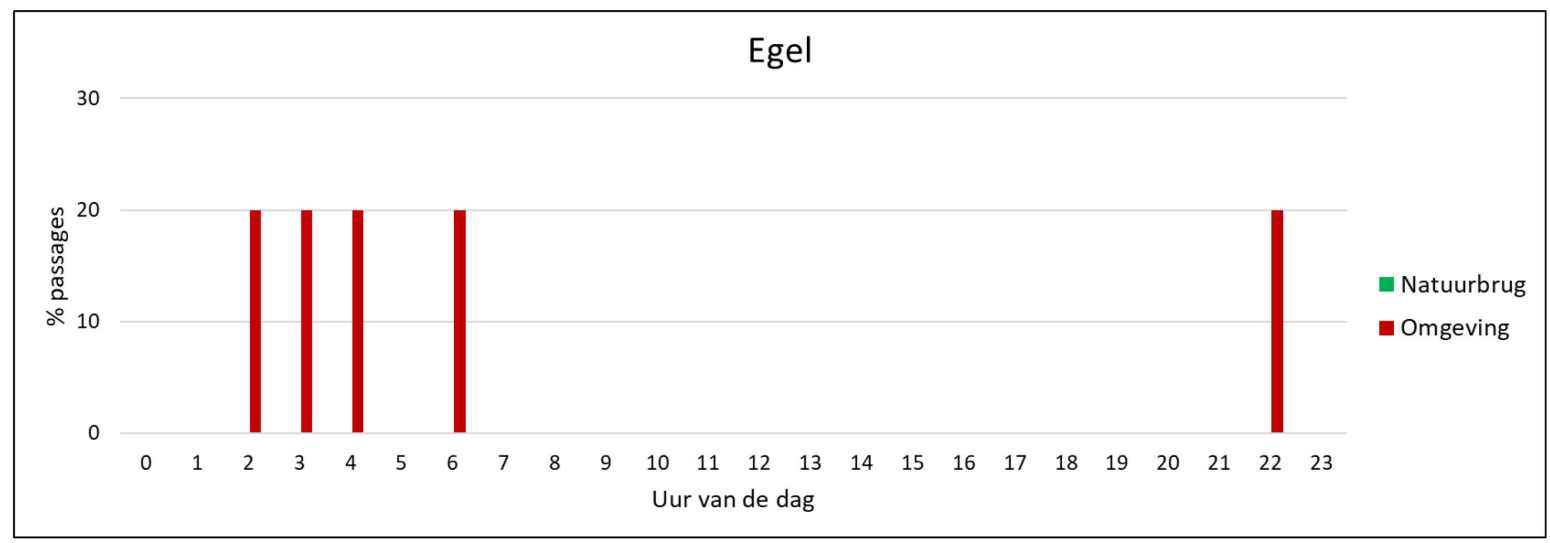

Figuur 36 Per soort de procentuele verdeling van het aantal passages over het etmaal voor zowel de natuurbrug als de omgeving.

\subsection{Gemiddeld tijdstip van passage}

Wat de doelsoorten voor de natuurbrug betreft, zien we voor ree en das dat ze gemiddeld later passeren dan op de referentieplekken in de omgeving (Figuur 37). Voor ree is het verschil gemiddeld 46 minuten en voor das 12 minuten (Figuur 38). De boommarter passeert gemiddeld juist eerder op de natuurbrug dan in de omgeving. Het verschil is hier meer dan twee uur. Voor ree is sprake van een significant verschil $(t=1,99, d f=629, p=0,047)$. Voor boommarter geldt dat niet $(t=-1,40, d f=16$, $p=0,181$ ) en is dus vooralsnog alleen sprake van een trend. Voor das kon niet op significantie worden getoetst, omdat het aantal waarnemingen te klein was.

Voor de overige soorten die op de natuurbrug zijn geregistreerd, zien we eveneens de trend dat deze gemiddeld later passeren dan op de referentieplekken in de omgeving. Voor bunzing is dit minder dan een halfuur, voor haas is dit bijna anderhalf uur en voor vos en eekhoorn is dit bijna twee uur. Voor $\operatorname{vos}(t=5,78, d f=380, p<0,001)$ en haas $(t=2,66, d f=373, p=0,008)$ is sprake van een significant verschil. Voor bunzing en eekhoorn kon niet op significantie worden getoetst, omdat het aantal waarnemingen voor deze soorten te klein was. 


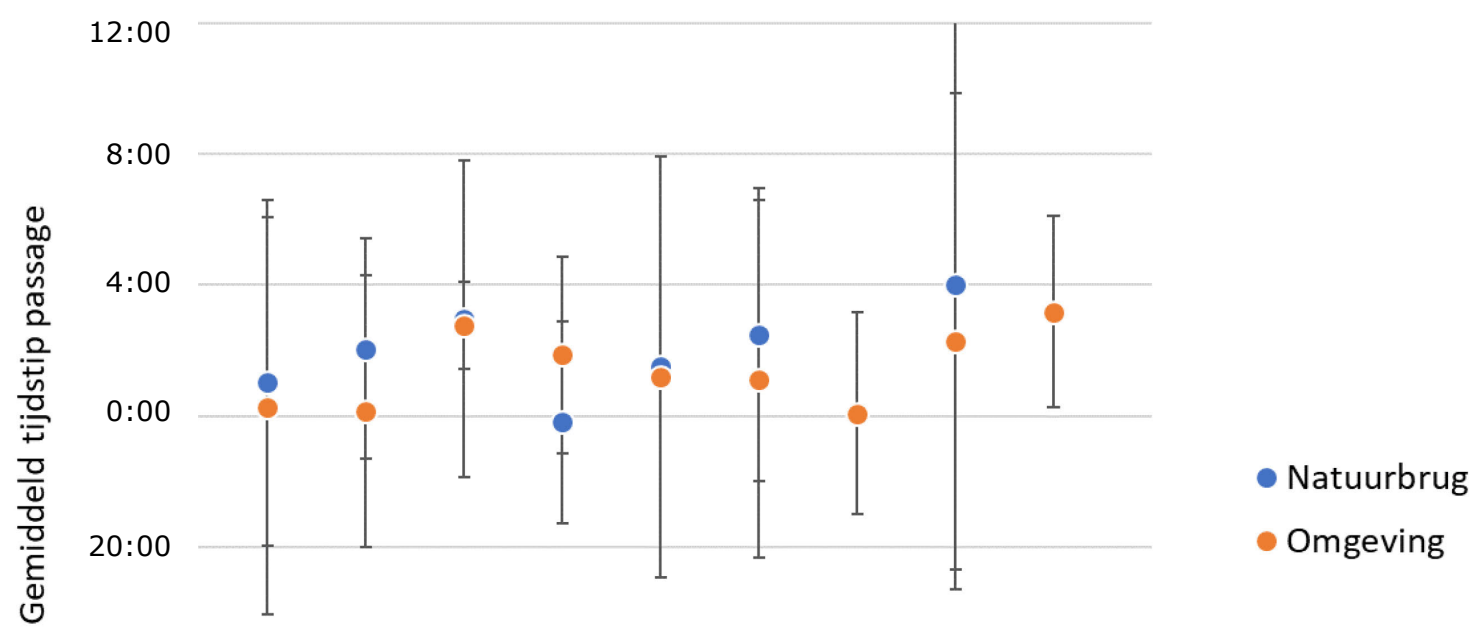

$16: 00$

$12: 00$

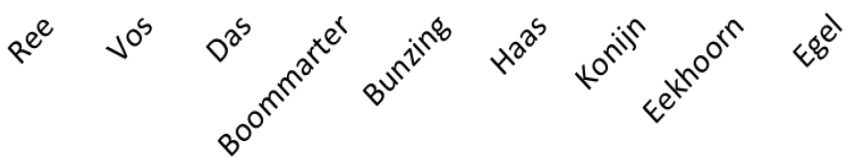

Figuur 37 Per soort het gemiddelde tijdstip van passeren, met de standaardafwijking voor zowel de natuurbrug als de omgeving.

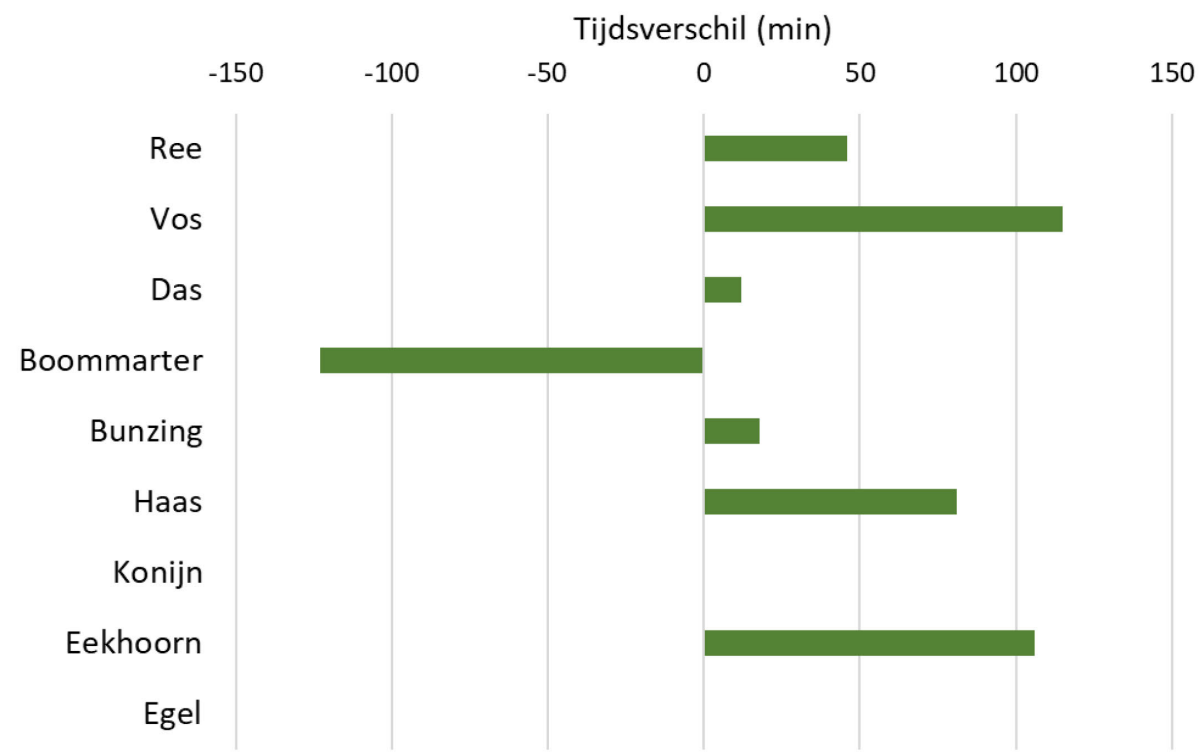

Figuur 38 Per soort het gemiddelde tijdsverschil tussen passages op de natuurbrug en passages in de omgeving.

\subsection{Verdeling passages over lichttoestand}

\section{Doelsoorten}

Bij vergelijking van de natuurbrug met de omgeving laat ree een significant verschil $\left(X^{2}=99,4 ; d f=2\right.$; $\mathrm{p}<0,001)$ zien in de procentuele verdeling van het aantal passages over de drie lichttoestanden (Figuur 39). In de omgeving passeren de dieren min of meer in gelijke proportie in donker en tijdens schemering/daglicht. Op de natuurbrug passeren reeën relatief vaker in donker (bijna $80 \%$ van het aantal passages) en minder bij zowel schemering als daglicht. Voor das en boommarter geldt dat er 
geen verschil is gevonden: alle passages van deze soorten, zowel op de natuurbrug als in de omgeving, vonden in donker plaats.

\section{Overige soorten}

Vos laat geen verschil zien tussen de natuurbrug en omgeving $\left(x^{2}=4,4 ; d f=2 ; p=0,109\right)$. Deze soort passeert op beide plekken vooral in donker. Datzelfde geldt voor bunzing die, zowel op de natuurbrug als in de omgeving, alleen in donker is gepasseerd. Voor haas heeft in de omgeving een significant grotere proportie van de passages tijdens de schemering en in donker plaatsgevonden $\left(x^{2}=16,6\right.$; $\mathrm{df}=2 ; \mathrm{p}<0,001)$. Voor eekhoorn is een niet-significante trend zichtbaar, namelijk dat in de omgeving relatief vaker wordt gepasseerd tijdens daglicht en gedurende de schemering in vergelijking met de natuurbrug $\left(x^{2}=1,6 ; d f=2 ; p=0,453\right)$. Op de natuurbrug is de proportionele verdeling van de passages gelijk over licht en donker. Het betreft hier echter slechts twee dieren, dus een goed vergelijk is niet te maken.
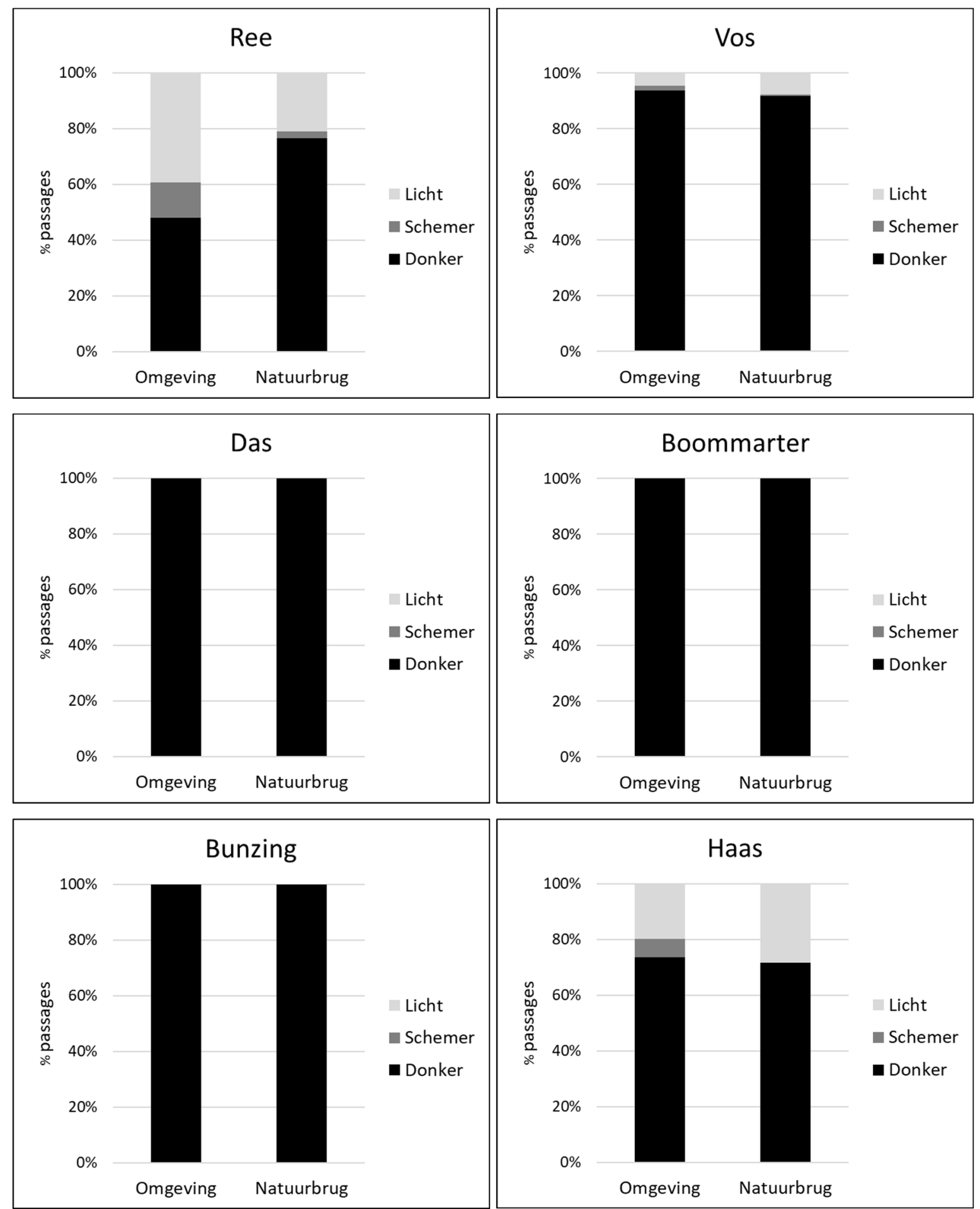

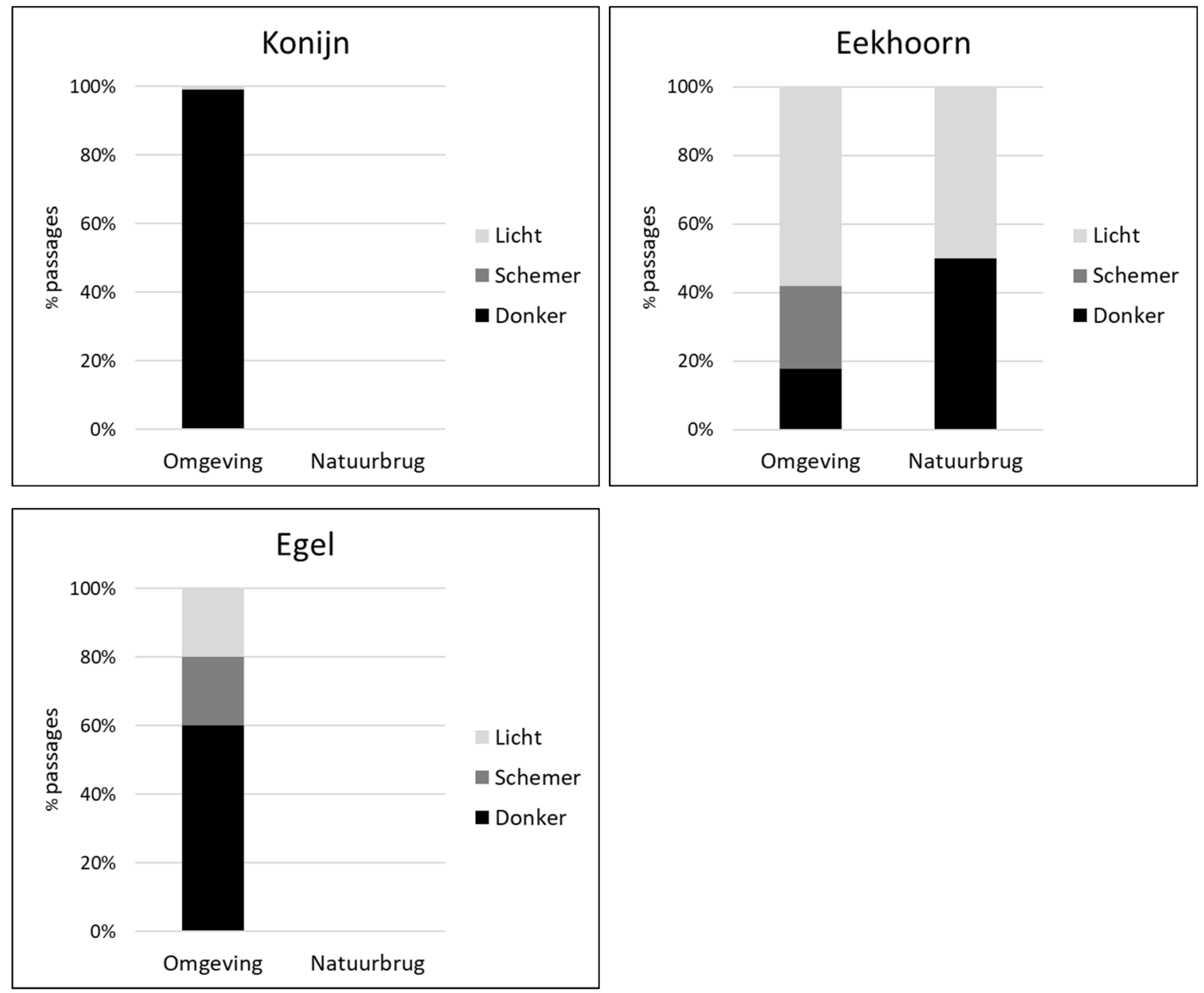

Figuur 39 Per soort de procentuele verdeling van de passages over de drie lichttoestanden, in de omgeving en op de natuurbrug.

\subsection{Geslachtsverhouding}

De geslachtsverhouding van ree op de natuurbrug is 1:0,62. Er passeren dus ruim $60 \%$ meer mannen dan vrouwen. Deze geslachtsverhouding verschilt significant met die in de omgeving $(1: 1,01)$, waar het aantal mannen en vrouwen dat passeert min of meer gelijk is $\left(x^{2}=9,3 ; d f=1 ; p=0,002\right)$.

Voor de doelsoort ree is er een significant verschil tussen mannelijke en vrouwelijke dieren in de procentuele verdeling van het aantal passages op de natuurbrug over het jaar $\left(x^{2}=91,5 ; d f=11\right.$; $\mathrm{p}<0,001)$. Reebokken passeren relatief vaker in de periode maart-juli. Vanaf augustus neemt dit af, om gedurende het najaar en de winter min of meer in gelijke proporties te passeren. Reegeiten passeren relatief weinig in de periode februari-juli. In de maanden april-mei zijn reegeiten bijna geheel afwezig. Vanaf augustus neemt het gebruik van de brug door reegeiten weer toe. Ze passeren relatief het meest in de periode oktober-december (Figuur 40).

In de omgeving is er eveneens een significant verschil tussen mannelijke en vrouwelijke dieren wat betreft de procentuele verdeling van het aantal passages over het jaar $\left(x^{2}=26,1 ; d f=11 ; p=0,006\right)$. $\mathrm{Na}$ relatief zeer weinig passages in het vroege voorjaar, neemt het aantal passages van reebokken snel toe in april, mei en juni. In de eerste zomermaanden is de activiteit relatief beperkt, maar dit neemt sterk toe in september en bereikt een piek in oktober. Vervolgens daalt het aantal passages van reebokken weer, hoewel de dieren ook in de eerste wintermaanden blijven passeren. In februari neemt het aantal nog verder af. Reegeiten verschillen van dit patroon met relatief weinig passages in april-mei en juist meer passages dan de bokken in het najaar. 
Vergelijken we de procentuele verdeling van een geslacht op de natuurbrug met die in de omgeving, dan zien we dat deze voor zowel reebokken $\left(x^{2}=61,1 ; d f=11 ; p<0,001\right)$ als reegeiten $\left(x^{2}=45,1\right.$; $\mathrm{df}=11 ; \mathrm{p}<0,001)$ significant van elkaar verschilt. In de omgeving passeren bokken relatief weinig in februari-maart en relatief veel in september-oktober. Op de natuurbrug ontbreken dit dal en deze piek in het aantal passages en zien we relatief veel activiteit tussen maart en juli. In de omgeving laten reegeiten een duidelijke piek zien in september-oktober, welke ontbreekt op de natuurbrug.
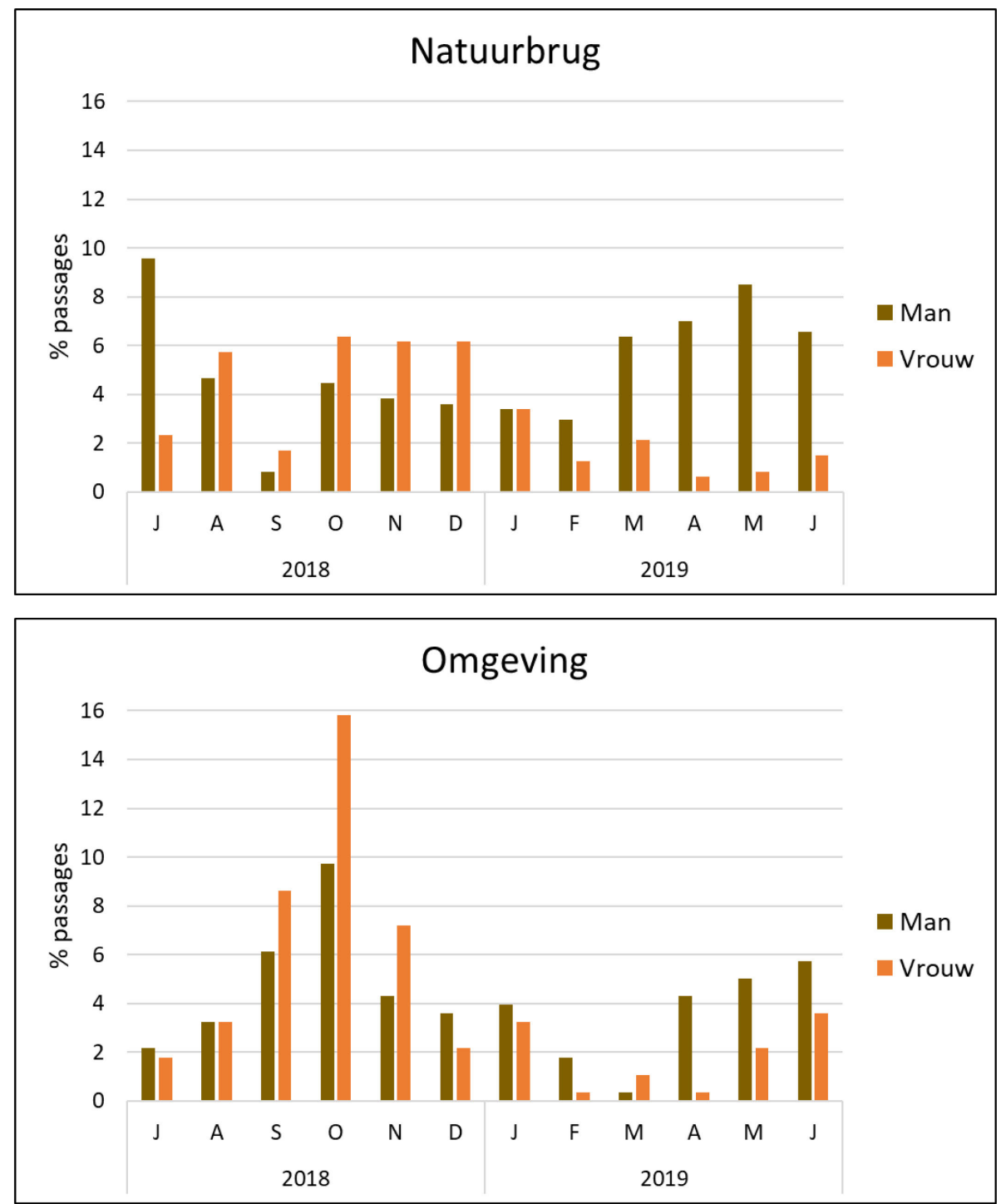

Figuur 40 Voor de doelsoort ree per geslacht de procentuele verdeling van de passages over het jaar, op de natuurbrug (boven) en in de omgeving (onder).

\subsection{Leeftijdsverdeling}

Op de natuurbrug is $21 \%$ van alle geregistreerde reeën een juveniel. In de omgeving is dit $19 \%$. De leeftijdsverdeling van ree op de natuurbrug is $1: 0,26$, in de omgeving is deze verhouding 1:0,24. De leeftijdsverdeling op de natuurbrug verschilt daarmee niet significant van die in de omgeving $\left(x^{2}=0,2\right.$; $d f=1 ; p=0,623)$.

Voor de doelsoort ree is er een significant verschil tussen adulte en juveniele dieren in de procentuele verdeling van het aantal passages op de natuurbrug over het jaar $\left(X^{2}=97,8 ; d f=11 ; p<0,001\right)$.

Adulten zijn vrij gelijkmatig over alle maanden op de natuurbrug waargenomen, met alleen relatief minder passages in september, januari en februari. Juveniele dieren zijn pas vanaf augustus op de 
brug gezien. Vanaf oktober neemt het aantal waarnemingen van juveniele dieren toe, om na de winter weer te dalen (Figuur 41). In de omgeving is er eveneens een significant verschil tussen adulte en juveniele dieren wat betreft de procentuele verdeling van het aantal passages over het jaar $\left(X^{2}=23,0\right.$; $\mathrm{df}=11 ; \mathrm{p}=0,018)$. Adulten worden het hele jaar waargenomen, maar laten een duidelijke piek in september-oktober en een dal in februari-maart zien. Juveniele dieren verschijnen vanaf juni en kennen een piek in oktober.

Vergelijken we de procentuele verdeling van een leeftijdsgroep op de natuurbrug met die in de omgeving, dan zien we dat deze voor zowel adulten $\left(X^{2}=91,8 ; d f=11 ; p<0,001\right)$ als juvenielen $\left(X^{2}=50,4 ; d f=9 ; p<0,001\right)$ significant van elkaar verschilt. Adulten maken vrij gelijkmatig gebruik over het jaar van de natuurbrug, maar laten in de omgeving een duidelijke piek (september-oktober) en dal (februari-maart) zien wat betreft hun activiteit. De verschillen in het patroon van juvenielen is subtieler. In de maanden juni-oktober zijn juveniele dieren in de omgeving relatief meer waargenomen dan op de natuurbrug, in de periode december-maart juist relatief minder.
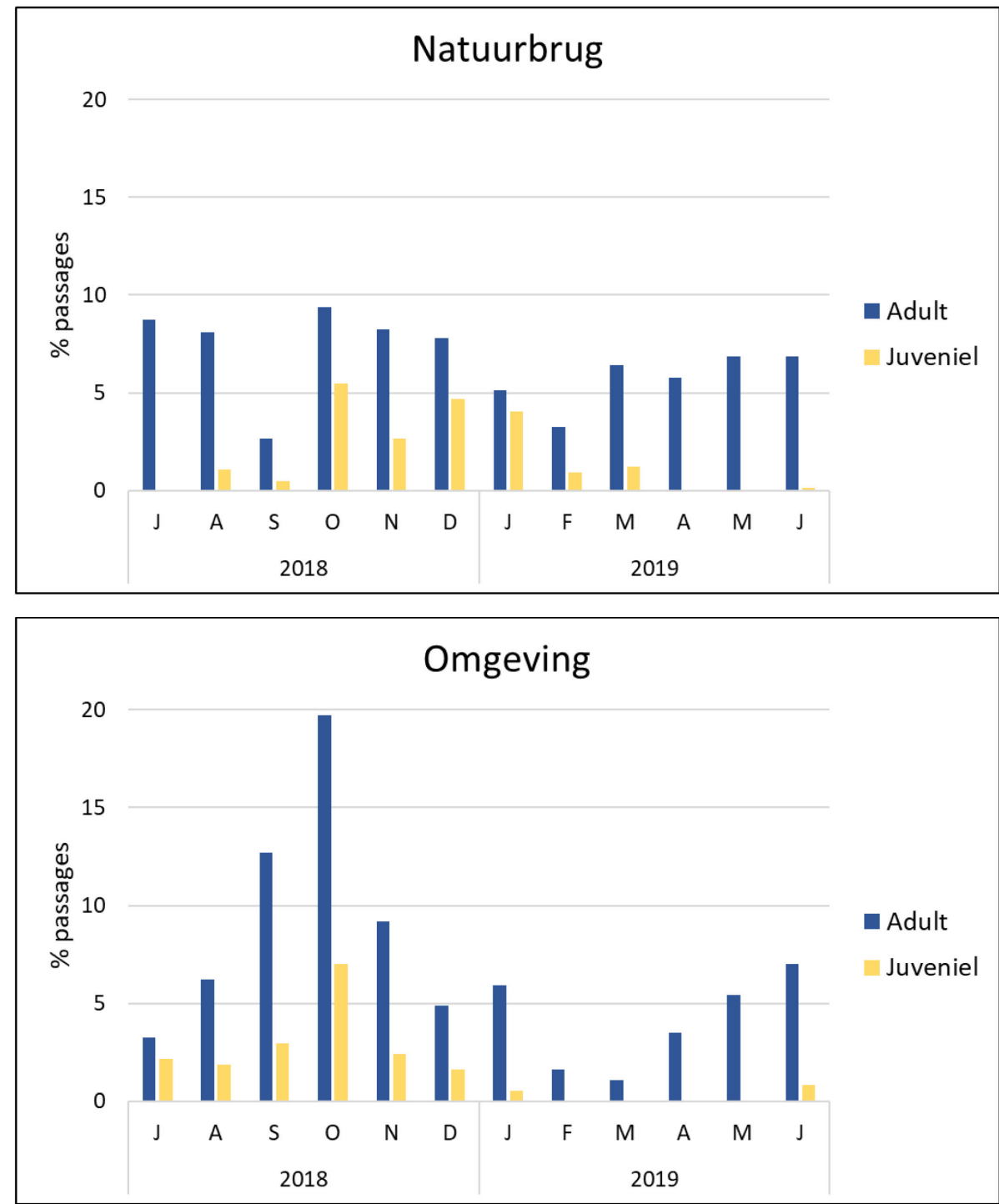

Figuur 41 Voor de doelsoort ree per leeftijdsgroep de procentuele verdeling van de passages over het jaar, op de natuurbrug (boven) en in de omgeving (onder). 


\subsection{Loopwijze}

\section{Doelsoorten}

Meer dan $90 \%$ van de reeën passeert in de omgeving in stap (Figuur 42). Op de natuurbrug is dit significant minder (circa 50\%) en passeren de dieren veel vaker in zowel draf als galop $\left(X^{2}<0,001\right.$; $d f=2 ; p<0,001)$. Ook de das passeert in de omgeving vooral in stap (67\%), en daarnaast in draf. Dit beeld is echter gebaseerd op slechts drie waarnemingen, dus niet robuust. Op de brug passeert circa driekwart van de dassen in draf en de rest in stap. Door het geringe aantal waarnemingen in de omgeving is voor de das geen goede statistische vergelijking te maken. Ruim $60 \%$ van de boommarters passeert in de omgeving in sprongengalop. Daarnaast bewegen ze hier vooral in stap bijna $30 \%$ van het aantal registraties - en voor een klein deel in sluipgang. Op de natuurbrug passeren de dieren minder vaak in sprongengalop en stap en meer in sluipgang. Dit verschil tussen omgeving en natuurbrug is niet significant en dient dus gezien te worden als een trend $\left(x^{2}=0,5 ; d f=2\right.$; $\mathrm{p}<0,240)$.

\section{Overige soorten}

In de omgeving passeert bijna driekwart van de vossen in stap, bijna een kwart in draf en slechts een klein aantal in sluipgang of galop. Op de natuurbrug passeert de soort daarentegen vooral in draf. Ook is hier relatief vaker de loopwijze galop waargenomen. Deze verschillen zijn significant $\left(X^{2}<0,001\right.$; $\mathrm{df}=2 ; \mathrm{p}<0,001)$. Ook de loopwijze van haas verschilt significant tussen natuurbrug en omgeving, met circa $40 \%$ van de passages in sprongengalop op de natuurbrug tegenover circa $25 \%$ in de omgeving $\left(x^{2}<0,001 ; d f=1 ; p<0,001\right)$. Bunzing passeerde in de omgeving alleen in stap, terwijl op de brug alleen sluipgang en sprongengalop zijn waargenomen. Het aantal waarnemingen in de omgeving is echter te beperkt om een statistische vergelijking te maken. Datzelfde geldt voor de eekhoorn, die slechts tweemaal op de natuurbrug is waargenomen. In de omgeving passeert de soort vooral in huppelgang, op de natuurbrug zijn beide dieren in sprongengalop gepasseerd. Konijn en egel passeerden in de omgeving voor bijna $100 \%$ in respectievelijk huppelgang en stap.
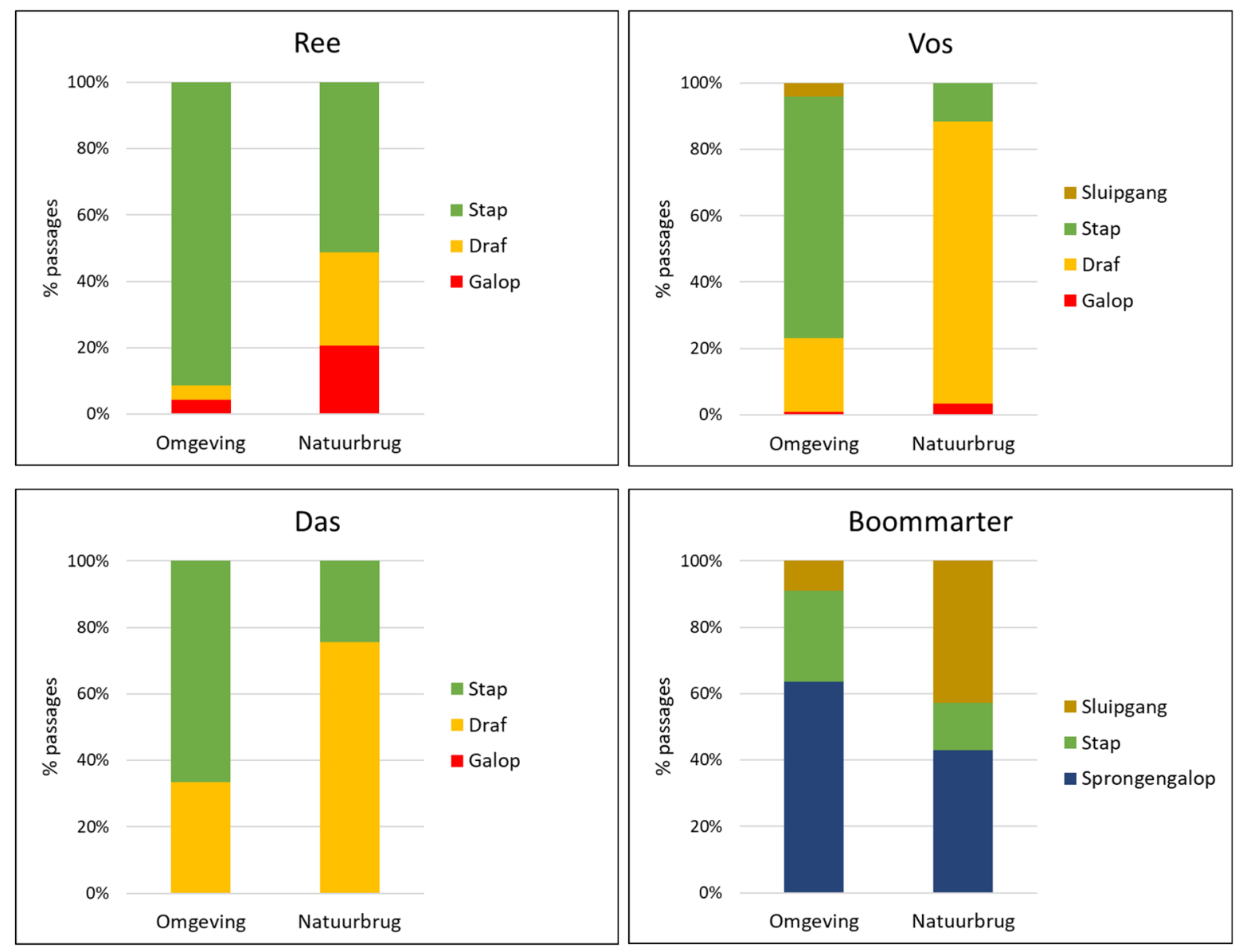

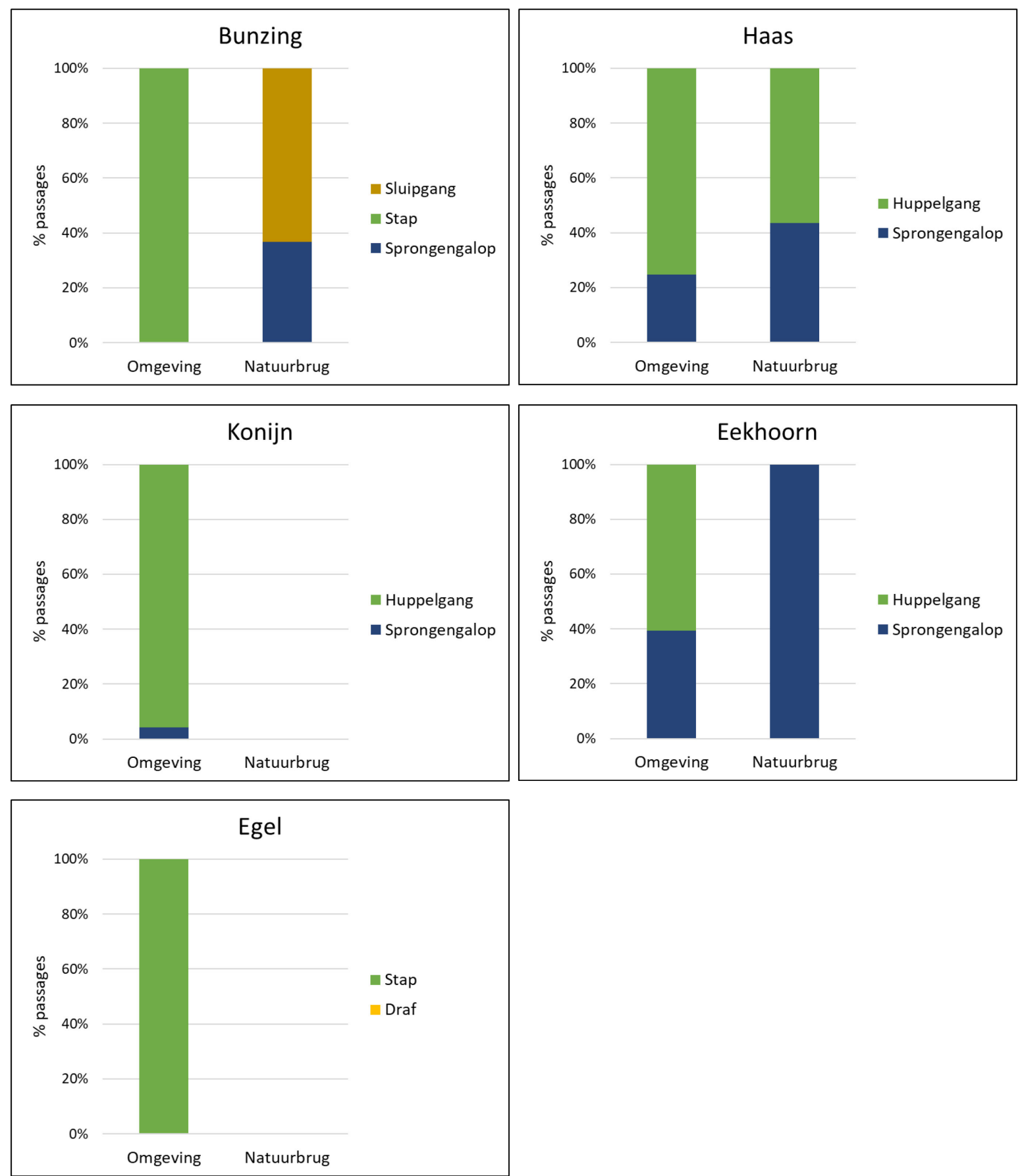

Figuur 42 Per soort de procentuele verdeling van de passages over de loopwijzen van de soort, in de omgeving en op de natuurbrug.

\subsection{Gedrag}

\section{Doelsoorten}

De meest voorkomende gedragsvorm van ree op de natuurbrug is passeren (Figuur 43). Circa $90 \%$ van de dieren vertoont dit gedrag. Daarnaast staat circa $20 \%$ van de dieren stil en/of laat gedrag zien dat wijst op alertheid. Minder dan 10\% van de dieren laat foerageergedrag zien op de natuurbrug. Ook in de omgeving is passeren de meest waargenomen gedragsvorm. Hier zijn echter ook vaker dieren waargenomen die stilstaan (circa 40\%) en foerageren (circa 25\%). Alert gedrag is in de omgeving relatief even vaak waargenomen als op de natuurbrug. De verschillen in gedragingen op de natuurbrug en in de omgeving zijn significant $\left(x^{2}<0,001 ; d f=5 ; p<0,001\right)$. 
De meest voorkomende gedragsvorm van das op de natuurbrug is passeren. Meer dan $95 \%$ van de dieren vertoont dit gedrag. Daarnaast staat circa $10 \%$ van de dieren stil en/of vertoont markeringsgedrag. Alert gedrag of foerageren is slechts incidenteel waargenomen. In de omgeving is passeren de enige waargenomen gedragsvorm. Hier zijn echter slechts drie waarnemingen van de das gedaan, dus het beeld is niet robuust. Door dit lage aantal waarnemingen in de omgeving is een goed vergelijk tussen natuurbrug en omgeving niet te maken.

De meest voorkomende gedragsvorm van boommarter op de natuurbrug is passeren. Circa $85 \%$ van de dieren vertoont dit gedrag. Daarnaast staat circa 30\% van de dieren stil en/of vertoont foerageergedrag. Alert gedrag is bij $15 \%$ van de passages waargenomen. In de omgeving is passeren door alle waargenomen dieren vertoond. Daarnaast staat circa $20 \%$ van de dieren stil, laat circa $10 \%$ van alle dieren alert gedrag zien en wordt ook foerageergedrag tijdens circa $10 \%$ van de passages vertoond. Het aantal waarnemingen - zowel op de natuurbrug als in de omgeving - is echter beperkt, dus het beeld is niet robuust. De verschillen in gedragingen op de natuurbrug en in de omgeving zijn niet significant $\left(x^{2}=7,0 ; d f=3 ; p=0,929\right)$.

\section{Overige soorten}

De meest voorkomende gedragsvorm van vos op de natuurbrug is passeren (Figuur 43). Nagenoeg $100 \%$ van de dieren vertoont dit gedrag. Daarnaast staat circa $7 \%$ van de dieren stil. Alert gedrag, jagen en markeren zijn alle tijdens minder dan $5 \%$ van de passages van de natuurbrug gezien. Ook in de omgeving is passeren de meest waargenomen gedragsvorm (circa 90\%). Hier zijn echter vaker dieren waargenomen die stilstaan (circa 20\%). Ook alert gedrag en markeren komen relatief iets vaker voor in de omgeving. Jagen is ook hier slechts incidenteel waargenomen. De verschillen in gedragingen op de natuurbrug en in de omgeving zijn significant $\left(x^{2}<0,01 ; d f=5 ; p<0,001\right)$.

De meest voorkomende gedragsvorm van bunzing op de natuurbrug is passeren. Circa $90 \%$ van de dieren vertoont dit gedrag. Daarnaast staan relatief veel dieren - circa $60 \%$ - stil. Alert gedrag, jagen en markeren zijn ook vertoond, maar alle tijdens minder dan $10 \%$ van de passages op de natuurbrug. Bunzing heeft relatief veel 'overig' gedrag laten zien, waaronder liggen, wassen en sociale interactie (tussen adult en jong). In de omgeving zijn passeren en stilstaan gedragsvormen die tijdens beide passages werden gezien. Alert gedrag is tijdens één passage vertoond. Door het lage aantal waarnemingen in de omgeving is een goed vergelijk tussen natuurbrug en omgeving niet te maken.

De meest voorkomende gedragsvorm van haas op de natuurbrug is passeren. Circa $85 \%$ van de dieren vertoont dit gedrag. Daarnaast staan relatief veel dieren - circa $30 \%$ - stil. Alert gedrag is in circa $15 \%$ van de passages vertoond. Voor foerageren is dit percentage $10 \%$. In de omgeving is passeren ook de meest vertoonde gedragsvorm. Daarnaast zijn hier stilstaan, alert gedrag en foerageren relatief vaker vertoond dan op de natuurbrug. De verschillen in gedragingen op de natuurbrug en in de omgeving zijn niet significant $\left(x^{2}=1,4 ; d f=4 ; p=0,153\right)$.

De twee eekhoorns die op de natuurbrug zijn waargenomen, hebben passeren, stilstaan en alert gedrag laten zien. In de omgeving is passeren de meest waargenomen gedragsvorm, maar zijn ook relatief veel dieren waargenomen die stilstaan en/of foerageren. Door het lage aantal waarnemingen op de natuurbrug is een goed vergelijk tussen natuurbrug en omgeving niet te maken. In de omgeving zijn voor konijn passeren en stilzitten de meest vertoonde gedragingen, waargenomen tijdens respectievelijk circa $75 \%$ en $65 \%$ van de passages. Alert gedrag en foerageren is tijdens circa $25 \%$ van de passages vertoond. In de omgeving zijn egels vooral gepasseerd en heeft een deel van deze dieren ook foerageergedrag vertoond. 

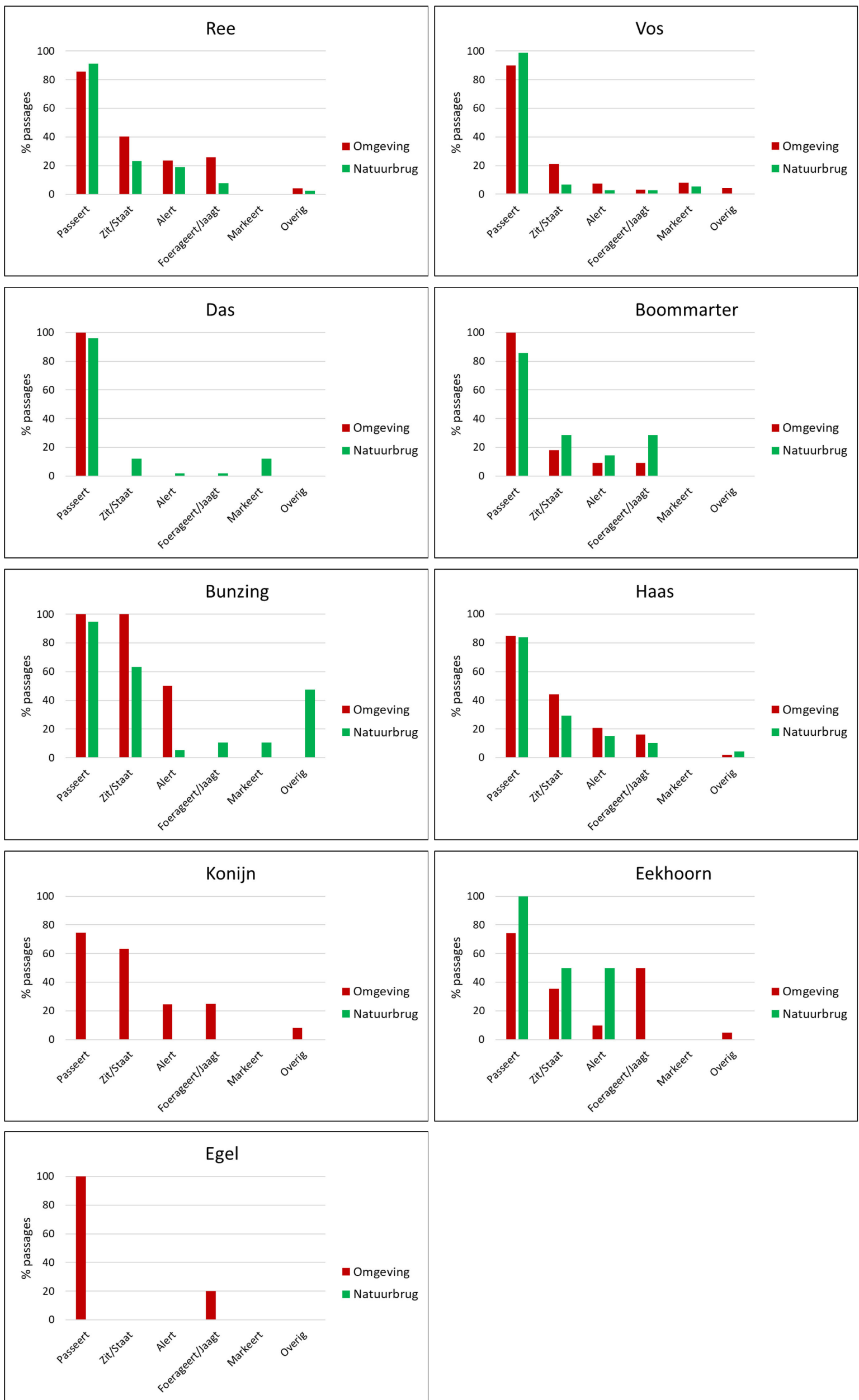

Figuur 43 Per soort de procentuele verdeling van de passages over de door de soort vertoonde gedragsvormen, in de omgeving en op de natuurbrug. 


\subsection{Toetsing functionaliteit natuurbrug}

Het in paragraaf 3.3 gepresenteerde toetsingskader om het functioneren van de natuurbrug te evalueren, omvat 18 meetbare doelen. Sommige van deze doelen kunnen echter verdeeld worden in twee of drie 'subdoelen', omdat de doelsoorten apart beoordeeld worden. Dit betekent dat we hier 44 indicatoren gebruiken om het functioneren van de natuurbrug te toetsen.

Tabel 4.3 geeft een overzicht van de doelen, de bevindingen en de beoordeling. De tabel laat zien dat 6 van de 8 primaire (sub)doelen (75\%) voor de natuurbrug zijn bereikt. Alle doelsoorten zijn er geregistreerd en hebben een voldoende grote trefkans. Ree en das passeren in een voldoende hoge frequentie. Daar tegenover staat dat nog niet alle in de omgeving geregistreerde middelgrote zoogdieren op de brug zijn gezien en het aantal passages van boommarter wat achterblijft bij het gestelde doel. Van de 6 secundaire (sub)doelen zijn er 5 bereikt ( $83 \%$ ). De passagefrequentie van ree en das is aanmerkelijk hoger dan de gemiddelde passagefrequentie in de omgeving. Er is voor deze soorten dus sprake van 'stuwing'. Alleen voor de boommarter geldt dit nog niet. Deze soort is op de brug en op plekken binnen geschikte biotoop in de omgeving in min of meer gelijke frequenties aangetroffen. Het ambitieuzere doel - een vergelijkbare passagefrequentie tussen natuurbrug en referentieplekken in de omgeving waar de soort is geregistreerd - is net niet gehaald.

Van de dertig tertiaire (sub)doelen zijn er zes bereikt (20\%). Acht van deze (sub)doelen zijn niet bereikt (27\%) en voor zestien (sub)doelen (53\%) kan geen beoordeling worden gegeven, omdat de verzamelde gegevens dat niet toelaten. Voor ree was een beoordeling mogelijk voor alle tien tertiaire doelen. Twee doelen voor deze soort zijn behaald, de overige acht niet. De verdeling van passages over het jaar op de brug en in de omgeving verschilt voor deze soort niet en ook de leeftijdsverdeling, dus de verhouding tussen adulte en juveniele dieren, komt overeen. Voor das was een beoordeling mogelijk voor slechts één tertiair doel, dat is behaald: de procentuele verdeling van het aantal passages over de lichttoestanden is op de natuurbrug vergelijkbaar met die in de omgeving. Voor boommarter was een beoordeling mogelijk voor drie tertiaire doelen, die alle drie zijn behaald: het tijdstip van passeren, de procentuele verdeling van het aantal passages over de lichttoestanden en de loopwijze verschilt voor deze soort op de brug niet significant van die in de omgeving. 
Tabel 4.3 De gestelde doelen voor het gebruik van de natuurbrug, de bevindingen en de beoordeling of een doel wel $(\sqrt{ })$ of niet $(\sqrt{ })$ gehaald is, of dat er onvoldoende gegevens zijn om een oordeel te vellen (-). Wanneer een doel voor meerdere doelsoorten geldt, zijn deze soorten individueel beoordeeld. In dat geval zijn er in de kolom 'Oordeel' dus twee of drie beoordelingen opgenomen.

\section{A. Primaire doelen, gericht op het realiseren van de minimaal gewenste uitwisseling}

\begin{tabular}{|c|c|c|c|}
\hline Doel & Beschrijving & Bevinding & Oordeel \\
\hline 1 & $\begin{array}{l}\text { De middelgrote zoogdieren die als doelsoort voor } \\
\text { de natuurbrug zijn aangewezen, maken gebruik } \\
\text { van de natuurbrug. }\end{array}$ & $\begin{array}{l}\text { Ree, das en boommarter maken gebruik van } \\
\text { de natuurbrug. }\end{array}$ & \\
\hline 2 & $\begin{array}{l}\text { Middelgrote zoogdiersoorten die zijn geregistreerd } \\
\text { op de referentieplekken rondom de natuurbrug } \\
\text { maken alle gebruik van de natuurbrug. }\end{array}$ & $\begin{array}{l}\text { Twee soorten - konijn en egel - zijn } \\
\text { vooralsnog niet waargenomen op de } \\
\text { natuurbrug. }\end{array}$ & \\
\hline 3 & $\begin{array}{l}\text { Reeën maken frequent gebruik van de } \\
\text { natuurbrug, gemiddeld eenmaal per dag. }\end{array}$ & $\begin{array}{l}\text { De gemiddelde passagefrequentie van ree is } \\
\text { circa twee dieren per dag. }\end{array}$ & \\
\hline 4 & $\begin{array}{l}\text { De trefkans van reeën op de natuurbrug is }>50 \% \text {, } \\
\text { dus gemiddeld wordt/worden minimaal een op de } \\
\text { twee dagen een of meer passerende dieren } \\
\text { geregistreerd. }\end{array}$ & Ree heeft een trefkans van $57 \%$. & \\
\hline 6 & $\begin{array}{l}\text { Op de korte termijn is de trefkans van dassen en } \\
\text { boommarters op de natuurbrug }>2 \% \text {, dus } \\
\text { gemiddeld wordt/worden minimaal } 7 \text { dagen per } \\
\text { jaar een of meer passerende dieren geregistreerd. }\end{array}$ & $\begin{array}{l}\text { Das heeft een trefkans van } 12 \% \text {. } \\
\text { Boommarter heeft een trefkans van } 2 \% \text {. }\end{array}$ & \\
\hline
\end{tabular}

\section{B. Secundaire doelen, gericht op het maximaliseren van de uitwisseling}

\begin{tabular}{|c|c|c|c|}
\hline Doel & Beschrijving & Bevinding & Oordeel \\
\hline 7 & $\begin{array}{l}\text { De passagefrequentie van een doelsoort op de } \\
\text { natuurbrug is minimaal gelijk aan de gemiddelde } \\
\text { passagefrequentie van deze soort op referentie- } \\
\text { plekken binnen voor de soort geschikte biotopen. }\end{array}$ & $\begin{array}{l}\text { De passagefrequentie op de natuurbrug van } \\
\text { ree, das en boommarter is respectievelijk 9, } \\
70 \text { en } 1,2 \text { maal groter dan de gemiddelde } \\
\text { passagefrequentie op de referentieplekken. }\end{array}$ & \\
\hline 8 & $\begin{array}{l}\text { De passagefrequentie van een doelsoort op de } \\
\text { natuurbrug is minimaal gelijk aan de gemiddelde } \\
\text { passagefrequentie van deze soort op referentie- } \\
\text { plekken binnen voor de soort geschikte biotopen, } \\
\text { waar de soort ook is aangetroffen. }\end{array}$ & $\begin{array}{l}\text { De passagefrequentie op de natuurbrug van } \\
\text { ree en das is respectievelijk } 7 \text { en } 12 \text { maal } \\
\text { groter dan de gemiddelde passagefrequentie } \\
\text { op de referentieplekken. Voor boommarter } \\
\text { is deze } 1,3 \text { maal kleiner. }\end{array}$ & \\
\hline
\end{tabular}




\section{Tertiaire doelen, gericht op het karakter van de uitwisseling}

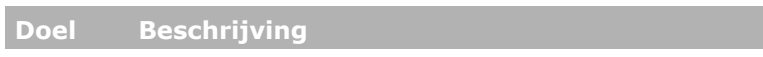

9 De procentuele verdeling van het aantal passages op de natuurbrug over het jaar komt overeen met die op referentieplekken binnen voor de doelsoort geschikte biotopen.

10 De procentuele verdeling van het aantal passages op de natuurbrug over het etmaal komt overeen met die op referentieplekken binnen voor de doelsoort geschikte biotopen.

11 Het gemiddelde tijdstip waarop een doelsoort de natuurbrug passeert, komt overeen met het gemiddelde tijdstip van passeren op referentieplekken binnen voor de soort geschikte biotopen.

De procentuele verdeling van het aantal passages over de lichttoestanden licht/schemer/donker op de natuurbrug komt overeen met die op referentieplekken binnen voor de doelsoort geschikte biotopen.

13 De geslachtsverhouding van een doelsoort op de natuurbrug komt overeen met de gemiddelde geslachtsverhouding op referentieplekken binnen voor de soort geschikte biotopen.

14 De procentuele verdeling van het aantal passages van mannelijke dan wel vrouwelijke dieren op de natuurbrug over het jaar komt overeen met die op referentieplekken binnen voor de doelsoort geschikte biotopen.

15 De leeftijdsverdeling van een soort op de natuurbrug komt overeen met de gemiddelde leeftijdsverdeling op referentieplekken binnen voor de soort geschikte biotopen.

16 De procentuele verdeling van het aantal passages van adulte dan wel juveniele dieren op de natuurbrug over het jaar komt overeen met die op referentieplekken binnen voor de doelsoort geschikte biotopen.

17 De manier van lopen waarmee een doelsoort de natuurbrug passeert, komt overeen met de loopwijze op referentieplekken binnen voor de soort geschikte biotopen.

$18 \quad$ Het gedrag dat de doelsoort op de natuurbrug vertoont, komt overeen met het gedrag op referentieplekken binnen voor de soort geschikte biotopen.
Bevinding

De procentuele verdeling van het aantal passages over het jaar komt voor het ree overeen met die in de omgeving. Voor das en boommarter zijn het aantal

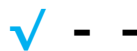

waarnemingen te beperkt voor een goed vergelijk.

De procentuele verdeling van het aantal passages over het etmaal komt voor het ree niet overeen met die in de omgeving. Voor das en boommarter is het aantal

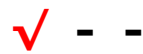
waarnemingen te beperkt voor een goed vergelijk.

Ree passeert de natuurbrug gemiddeld significant later dan op de referentieplekken. Voor das kon geen significantietest $\sqrt{ }-\sqrt{ }$ worden uitgevoerd door een te kleine steekproef. Voor boommarter kon geen significant verschil worden gevonden.

Ree laat een significant verschil zien: de soort passeert de natuurbrug relatief vaker in donker. Das en boommarter laten geen verschil zien tussen natuurbrug en omgeving.

De geslachtsverhouding van ree verschilt op de natuurbrug significant van die in de omgeving. De geslachtsverhouding van das en boommarter kon niet worden bepaald. Voor zowel reebokken als -geiten is er een significant verschil in de procentuele verdeling van de passages over het jaar tussen natuurbrug en omgeving. Voor das $\sqrt{-}-$ en boommarter kon dit niet worden bepaald. De leeftijdsverdeling van ree verschilt op de natuurbrug niet significant van die in de omgeving. De leeftijdsverdeling van das en boommarter kon niet worden bepaald.

Voor zowel adulte als juveniele reeën is er een significant verschil in de procentuele verdeling van de passages over het jaar tussen natuurbrug en omgeving. Voor das

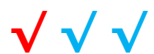
en boommarter kon dit niet worden bepaald.

In vergelijking met de omgeving passeert ree de natuurbrug significant vaker in draf en galop. Voor das kon geen goede vergelijking worden gemaakt door het beperkte aantal waarnemingen in de omgeving. Boommarter laat een nietsignificante trend zien naar meer sluipgang en minder stap en sprongengalop op de natuurbrug. Het gedrag van ree op de natuurbrug verschilt significant met dat van de soort in de omgeving. Voor das en boommarter geldt dat niet. Het beperkte aantal waarnemingen van deze twee doelsoorten maakt een goed vergelijk echter niet mogelijk. 


\subsection{Discussie}

De natuurbrug is drie jaar na de opening duidelijk al volop in gebruik door middelgrote zoogdieren, inclusief de drie doelsoorten ree, das en boommarter. Dat twee in de omgeving geregistreerde soorten - konijn en egel - tijdens het onderzoek niet op de natuurbrug zijn geregistreerd, betekent niet dat de natuurbrug niet geschikt is voor deze soorten. Konijn is een soort die, indien aanwezig, meestal niet alleen passeert, maar langere tijd op een natuurbrug verblijft om te foerageren (zie Van der Grift et al. 2009). Het is dan ook onwaarschijnlijk dat de soort wel gebruik van de brug heeft gemaakt, maar is gemist. Konijnen leven in familiegroepen en hebben een leefgebied dat varieert - afhankelijk van de groepsgrootte en de kwaliteit van de habitat - van minder dan 1 tot circa 6 ha. Dit betekent dat het leefgebied zich meestal niet verder uitstrekt dan enkele tientallen tot circa $150 \mathrm{~m}$ rond de burcht. Waar de dichtstbijzijnde kolonie zit, is niet onderzocht. Tijdens het onderzoek zijn echter geen konijnenburchten aangetroffen op de ecoducten, in het tussengebied of op de toelopen. Aangezien de toelopen circa $150 \mathrm{~m}$ lang zijn, lijkt de afwezigheid van konijn op de natuurbrug dan ook goed te verklaren. Afwezigheid van de egel lijkt vooral een gevolg van de zeer lage dichtheden waarin deze soort in het gebied voorkomt. De soort is op slechts twee referentieplekken waargenomen met in totaal 5 waarnemingen tijdens het onderzoeksjaar. Daarnaast is er ook een kans dat de soort op de natuurbrug is gemist, aangezien het een relatief kleine soort betreft. De ijking van de cameravallen in de palen maakte immers duidelijk dat deze meer moeite hadden met het registreren van passages van de relatief kleinere soorten, zoals haas (zie ook Tabel 3.6).

De gemeten passagefrequentie en relatief hoge trefkans van ree indiceren dat het gebruik van de natuurbrug vooral samenhangt met bewegingen binnen het leefgebied. Dit wordt ondersteund door het feit dat dezelfde reebokken - te herkennen aan hun gewei - vaak meerdere keren passeerden. In het najaar van 2018 is er ook een groep geweest - bestaande uit een reebok, reegeit en twee kalveren die frequent de brug passeerden, in beide richtingen. Als we de jaarlijkse passagefrequentie van ree op Natuurbrug Laarderhoogt vergelijken met die op andere onderzochte ecoducten in het Gooi of op de Utrechtse Heuvelrug, dan ligt deze onder het gemiddelde (Tabel 4.4). De aantallen liggen duidelijk hoger dan die op de natuurbruggen Beukbergen en Treeker Wissel, zijn min of meer vergelijkbaar met die van Huis ter Heide, maar liggen aanmerkelijk lager dan die van de natuurbruggen Leusderheide en Zanderij Crailoo.

Tabel 4.4 Passagefrequenties (per jaar) van de in deze studie geregistreerde middelgrote zoogdieren, op Natuurbrug Laarderhoogt en op natuurbruggen elders in het Gooi en op de Utrechtse Heuvelrug. Tevens de gemiddelde jaarlijkse passagefrequentie voor deze natuurbruggen.

\begin{tabular}{|c|c|c|c|c|c|c|c|c|c|}
\hline Natuurbrug & Ree & Vos & Das & $\begin{array}{l}\text { Boom- } \\
\text { marter }\end{array}$ & Bunzing & Haas & Konijn & Eekhoorn & Egel \\
\hline Laarderhoogt $^{1}$ & 711 & 510 & 56 & 6 & 19 & 669 & 0 & 2 & 0 \\
\hline Leusderheide ${ }^{3}$ & 1.871 & 679 & 0 & 0 & 0 & 145 & 2.375 & 0 & 0 \\
\hline Treeker Wissel $^{4}$ & 527 & 565 & 0 & 0 & 0 & 624 & 1.276 & 0 & 0 \\
\hline Huis ter Heide ${ }^{6}$ & 750 & 650 & 0 & 0 & 6 & 6 & 800 & 0 & 0 \\
\hline Gemiddeld & 1.056 & 695 & 10 & 4 & 4 & 274 & 1.144 & 1 & 0 \\
\hline
\end{tabular}

1 Deze studie

2 Van der Grift et al., 2009

3 De Keijzer et al., 2013

4 Smitskamp, 2010

5 De Keijzer et al., 2013

6 Emond \& Brandjes, 2015

De gemeten passagefrequentie en trefkans van de das indiceren dat de das de natuurbrug nog niet dagelijks gebruikt tijdens foerageertochten. Wellicht heeft de brug nu vooral een functie voor korte of lange verkenningstochten. Zo is de das tijdens slechts zeven nachten tweemaal geregistreerd, in de 
richting noord-zuid en vervolgens zuid-noord of vice versa. Alle overige passages waren de enige in de betreffende nacht. De brug wordt wellicht ook gebruikt voor dispersiebewegingen van jonge dieren.

Dit is op basis van de camerabeelden echter niet te bevestigen. Opvallend is wel dat de das in de loop van het onderzoek de natuurbrug vaker is gaan gebruiken. In het eerste halfjaar bleef het aantal beperkt tot enkele passages per maand. Vanaf februari 2019 nam dit toe tot gemiddeld zeven passages per maand. Als we de jaarlijkse passagefrequentie van de das op Natuurbrug Laarderhoogt vergelijken met die op andere onderzochte ecoducten in het Gooi of op de Utrechtse Heuvelrug, dan ligt deze ver boven het gemiddelde (Tabel 4.2). Behalve op Natuurbrug Laarderhoogt is de soort alleen op Natuurbrug Zanderij Crailoo geregistreerd. Daar betrof het enkele incidentele passages. Het gebied rondom deze natuurbrug was toen geen actueel leefgebied van de das. Uitwisseling via de natuurbrug heeft naar verwachting een rol gespeeld bij de herkolonisatie van het Spanderswoud en de aangrenzende landgoederenzone.

De gemeten passagefrequentie en trefkans van de boommarter indiceren dat deze soort nog geen vaste bewoner is van het gebied direct rond de natuurbrug. De boommarter is eenmaal geregistreerd in augustus 2018 - door de camera in de stobbenwal - en vervolgens pas weer in de maanden februari/maart 2019. In de laatste maanden van het onderzoek heeft de soort zich niet meer laten zien. Dit indiceert dat het hier waarschijnlijk om zwervende dieren gaat die de natuurbrug gedurende een relatief korte tijd gebruiken en dan weer uit het gebied verdwijnen. Dit wordt ondersteund door de metingen op de referentieplekken. Ook hier zien we dat de boommarter zeer onregelmatig in beeld komt en soms maanden niet wordt geregistreerd. Als we de jaarlijkse passagefrequentie van de boommarter op Natuurbrug Laarderhoogt vergelijken met die op andere onderzochte ecoducten in het Gooi of op de Utrechtse Heuvelrug, dan ligt deze boven het gemiddelde (Tabel 4.2). Behalve op Natuurbrug Laarderhoogt is de soort alleen op Natuurbrug Zanderij Crailoo geregistreerd. Net als voor de das was het gebied rondom deze natuurbrug toen geen actueel leefgebied van de boommarter. Uitwisseling via de natuurbrug heeft naar verwachting ook voor deze soort een rol gespeeld bij de herkolonisatie van het Spanderswoud. Natuurbrug Laarderhoogt kan de das en de boommarter vergelijkbare kansen bieden voor vestiging in nieuwe leefgebieden in het noordelijke Gooi.

Bij vergelijking van de passagefrequenties op de natuurbrug en die binnen geschikte biotoop in de omgeving blijkt dat de natuurbrug door zes van de zeven soorten vaker wordt gebruikt dan op basis van toeval mag worden verwacht (zie ook Figuur 34). Voor deze soorten is dus sprake van 'stuwing'. Dit is van belang, omdat hiermee wordt aangetoond dat een natuurbrug een grotere lengte van de infrastructurele barrière mitigeert dan zijn eigen breedte. Dit is iets wat men nastreeft bij het ontwerpen en bouwen van een dergelijke ontsnipperende maatregel. Natuurbruggen worden immers altijd in combinatie met faunarasters aangelegd. Deze zijn bedoeld om enerzijds de dieren van de weg te houden, anderzijds de dieren naar de faunapassage te geleiden. Een stuwingsindex $>1$ laat zien dat deze geleiding werkt. Een stuwingsindex van 9, zoals hier gevonden voor ree, betekent dus dat deze soort negenmaal vaker passeert dan op een willekeurige plek in de omgeving van dezelfde lengte. Bij Natuurbrug Laarderhoogt is voor één soort - de eekhoorn - een negatieve stuwingsindex gevonden. Dit betekent dat deze soort de brug minder vaak bezoekt dan op basis van toeval mag worden verwacht. Er is hier dus sprake van vermijding of ontwijking. Dit is van belang, omdat het indiceert dat de brug nog niet goed voor deze soort functioneert. Op basis van dit gegeven kan worden verkend of er aanvullende inrichtingsmaatregelen kunnen worden genomen om het gebruik door deze soort te bevorderen. De stuwingsindex - positief dan wel negatief - is een goede graadmeter om natuurbruggen onderling te vergelijken. Het vergelijken van absolute aantallen passages zegt in veel gevallen immers niet alles, omdat de dichtheden waarin soorten rond een ecoduct voorkomen sterk kunnen verschillen. De stuwingsindex houdt hier rekening mee - het is immers een maat waarin zowel de metingen op de natuurbrug als in de omgeving zijn meegenomen -, wat mogelijkheden biedt om het functioneren van diverse ecoducten te vergelijken en bijvoorbeeld het effect van verschillen in ontwerp te onderzoeken. De in paragraaf 4.5 gepresenteerde 'ambitieuzere' stuwingsindex, waarbij alleen referentieplekken zijn betrokken waar de soort ook daadwerkelijk is aangetroffen, is naar verwachting geschikter voor dergelijke vergelijkingen, omdat hiermee eventuele ruis door een verkeerde inschatting van 'geschikte biotoop' wordt voorkomen.

Dat we voor sommige soorten bij een vergelijking van de natuurbrug met de omgeving significante verschillen hebben gevonden in de procentuele verdeling van de passages over het jaar en/of het 
etmaal lijkt niet direct een groot probleem voor het functioneren van de natuurverbinding. In sommige gevallen kan het een indicatie zijn dat dieren hun gedrag aanpassen. We zien dat bijvoorbeeld bij reegeiten die zich in de maanden mei en juni, de tijd dat de kalveren worden geboren, op de natuurbrug nog minder laten zien dan in de omgeving in diezelfde maanden. In een periode van schuilhouden en extra alertheid is het gebruik van de natuurbrug voor reegeiten blijkbaar een stap te ver. Anderzijds zullen de verschillen in de verdeling van passages over het jaar en etmaal vooral op toeval zijn gebaseerd. Geen plek in een natuurgebied is gelijk. En dus ook het gebruik van die plekken door de diverse diersoorten niet. Dit blijkt al als we de referentieplekken onderling vergelijken: op geen van deze plekken is de procentuele verdeling van het aantal passages in de tijd precies gelijk aan die op een andere referentieplek. Dit pleit wellicht voor een minder strikte (statistische) toetsing van de significantie van de temporele verschillen. Wellicht kan beter gebruik worden gemaakt van een beslis-regel, zoals: het gemiddelde verschil, positief of negatief, tussen het percentage passages op de natuurbrug en in de omgeving over alle maanden, is maximaal $X$ procentpunten. Een procentpunt is het absolute verschil tussen waarden die in procenten zijn uitgedrukt. De grenswaarde $X$ kan vooraf worden gekozen. Bijvoorbeeld op basis van een expertoordeel over wat nog een acceptabel verschil is. Ons voorstel zou zijn om voor de verdeling over het jaar (12 maanden) de grenswaarde van 4,2 procentpunten te kiezen. Hoewel een enigszins arbitraire keuze, is deze waarde gebaseerd op het uitgangspunt dat bij een gelijke procentuele verdeling van alle passages op de natuurbrug over alle maanden, dus iedere maand $8,33 \%$ van de passages, het verschil met de omgeving gemiddeld niet groter mag zijn dan de helft van dat maandelijkse percentage. Om de grenswaarde te berekenen, is dus gebruikgemaakt van de formule: 100/12 maanden*0,5. Voor de verdeling over het etmaal kan dezelfde beslisregel worden gebruikt. Ons voorstel is in dat geval om de grenswaarde van 2,1 procentpunten te hanteren. Om deze grenswaarde te berekenen, is nu dus gebruikgemaakt van de formule: $100 / 24$ uur*0,5.

Voor de doelsoort ree hebben we vastgesteld dat deze soort later passeert op de natuurbrug in vergelijking met de omgeving. Ook passeert deze soort vaker in donker. Dit kan een indicatie zijn dat de dieren de natuurbrug duidelijk als 'anders' of 'gevaarlijker' beschouwen dan de rest van hun leefgebied. Deze waarneming is niet verrassend, ook in het onderzoek bij Natuurbrug Zanderij Crailoo is dit vastgesteld (Van der Grift et al., 2009). Het maakt de natuurverbinding ook niet per se minder functioneel voor deze soort, temeer omdat netto het aantal passages van de natuurbrug niet lager, maar juist hoger is dan het gemiddelde aantal passages in de omgeving. Het is dus vooral een gedragsaanpassing van de soort die ertoe bijdraagt dat deze de natuurverbinding zo optimaal mogelijk kan benutten.

Iets soortgelijks is te concluderen in relatie tot de loopwijze en het gedrag van de passerende dieren. De loopwijze van de meeste soorten is op de natuurbrug anders - sneller - in vergelijking met de omgeving. De dieren passeren er vaker in draf, galop of sprongengalop. Wat betreft gedrag zien we bij verschillende soorten dat er op de natuurbrug minder vaak wordt stilgestaan en minder wordt gefoerageerd. Ook hier lijkt dit te indiceren dat de dieren 'weten' dat ze de natuurbrug passeren en deze plek anders ervaren dan de referentieplekken in de omgeving. Vergelijkbare verschillen in loopwijze en gedrag zijn ook op Natuurbrug Zanderij Crailoo vastgesteld (Van der Grift et al., 2009). Hoewel de dieren idealiter het verschil tussen natuurbrug en omgeving niet opmerken, betekenen deze aanpassingen in loopwijze en gedrag dus niet dat de natuurbrug voor deze soorten niet meer functioneel is. 


\section{$5 \quad$ Gebruik natuurbrug door mens en huisdier}

\section{$5.1 \quad$ Inleiding}

Natuurbrug Laarderhoogt is opengesteld voor menselijk medegebruik. In dit hoofdstuk beschrijven we de omvang en aard van dit medegebruik. Hierbij gaat de aandacht ook uit naar 'illegaal' gebruik van de natuurbrug, dus met gemotoriseerde voertuigen, op tijden dat de brug verboden gebied is of gebruik op plekken die niet voor mensen zijn opengesteld. De natuurbrug is verboden gebied voor huisdieren. Toch passeren er honden en huiskatten. Ook aard en omvang van gebruik door huisdieren beschrijven we hier kort.

\subsection{Gebruik van de natuurbrug door mensen}

Het aantal mensen dat tijdens het onderzoeksjaar de natuurbrug heeft gebruikt, is geschat op ruim 65.000. De gemiddelde passagefrequentie van mensen is dan 179 per dag, 1.257 per week en 5.446 per maand. Tijdens het onderzoek is er geen dag geweest dat de natuurbrug niet door mensen is gebruikt; het laagste aantal passages van mensen was 28, geregistreerd op 21 december 2018. De meeste mensen passeren per fiets (76\%), gevolgd door voetgangers $(21 \%)$ en ruiters $(2 \%)$

(Figuur 44). Andere manieren van passeren vormen slechts $0,3 \%$ van het totaal. Dit betekent dat er dagelijks gemiddeld 136 fietsers, 38 voetgangers en 4 ruiters passeren (Figuur 45).

Er is een duidelijk verschil tussen werkdagen en de dagen van het weekend (Figuur 46). Op werkdagen passeren gemiddeld 125 mensen, op weekenddagen doen gemiddeld 316 mensen dat. Dit betekent dat circa $50 \%$ van het totale gebruik door mensen in het weekend plaatsvindt. Dit duidt erop dat het menselijk gebruik van de brug voor een groot deel om recreatief gebruik gaat. Meer dan $99 \%$ van het gebruik door mensen vindt plaats tussen 6:00 uur en 22:00 uur (Figuur 47). Van 6:00 uur tot 9:00 uur is het aantal passages nog relatief beperkt. Na 9:00 uur neemt het echter snel toe. Tussen 10:00 en 12:00 uur kent de natuurbrug het hoogste gebruik door mensen. Tussen 12:00 en 16:00 uur is het gebruik min of meer stabiel, met ieder uur circa $10 \%$ van het totaal aan dagelijkse passages. Tussen 16:00 en 18:00 uur neemt het gebruik snel af, om na 20:00 uur nog verder te dalen.
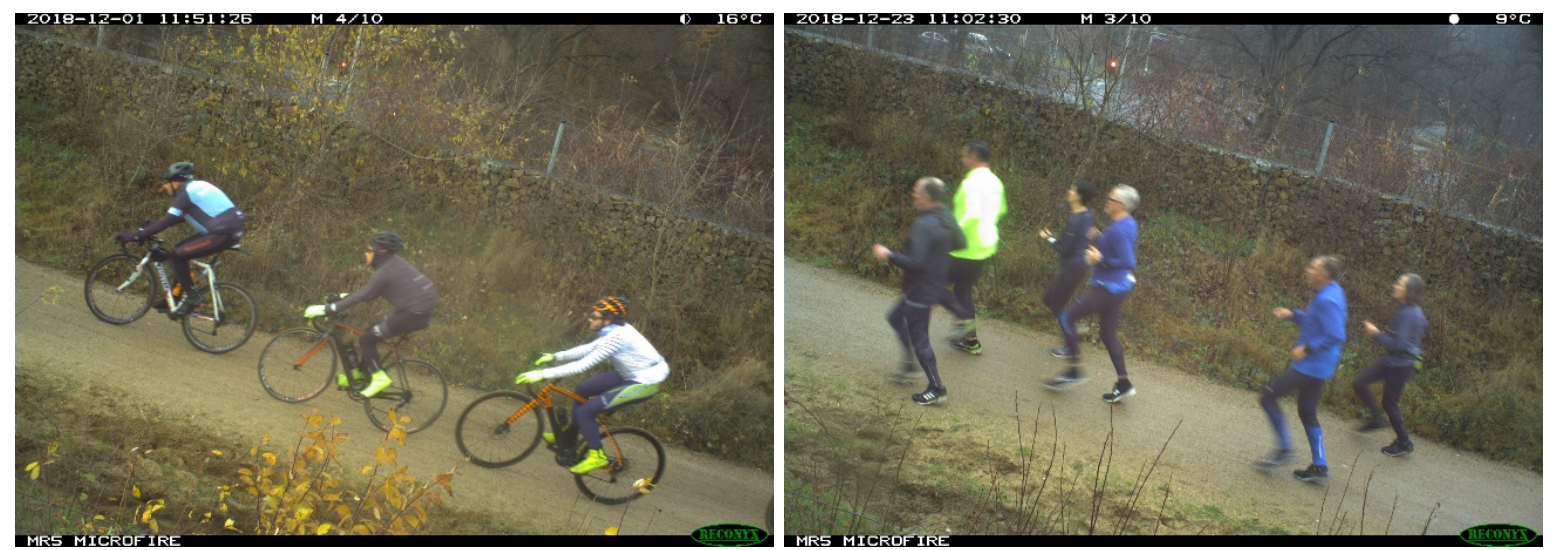

Figuur 44 De natuurbrug wordt vooral gebruikt door fietsers. In het weekend lijkt het een favoriete 'berg' in de trainingsrondjes van veel sportfietsers. De recorddag tijdens het onderzoek was 1 december 2018, toen 1.205 fietsers passeerden. Ook groepen hardlopers passeren frequent. 


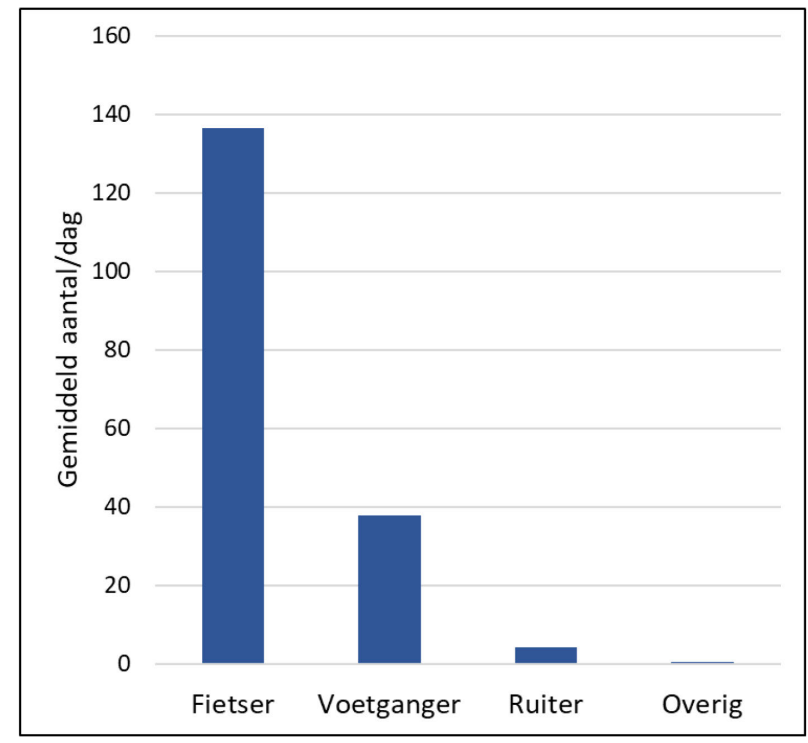

Figuur 45 Gemiddeld aantal mensen, per type, dat per dag gebruikmaakt van de natuurbrug.

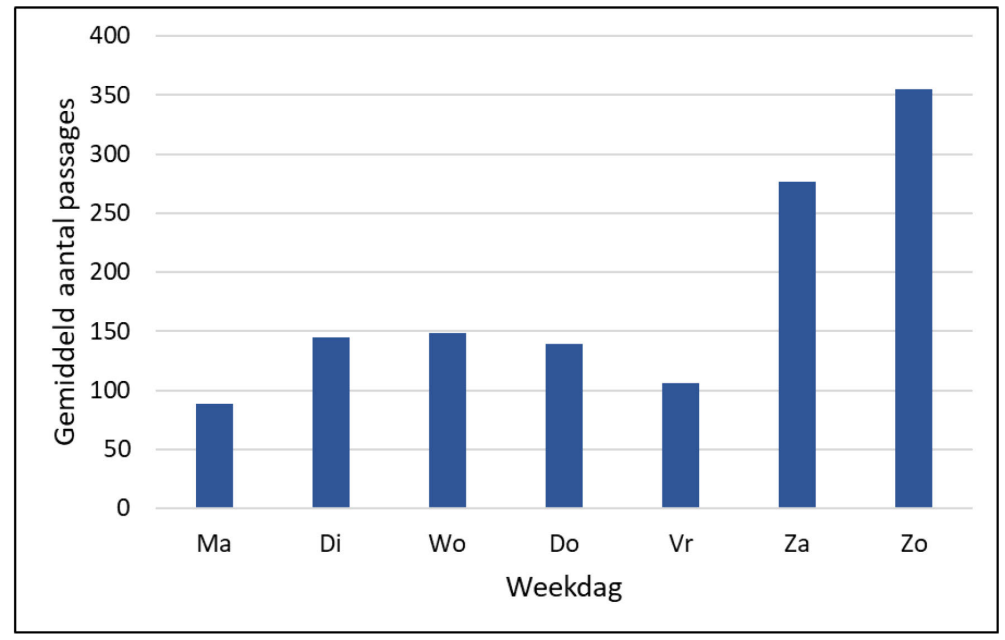

Figuur 46 Gemiddeld aantal mensen dat per weekdag gebruikmaakt van de natuurbrug.

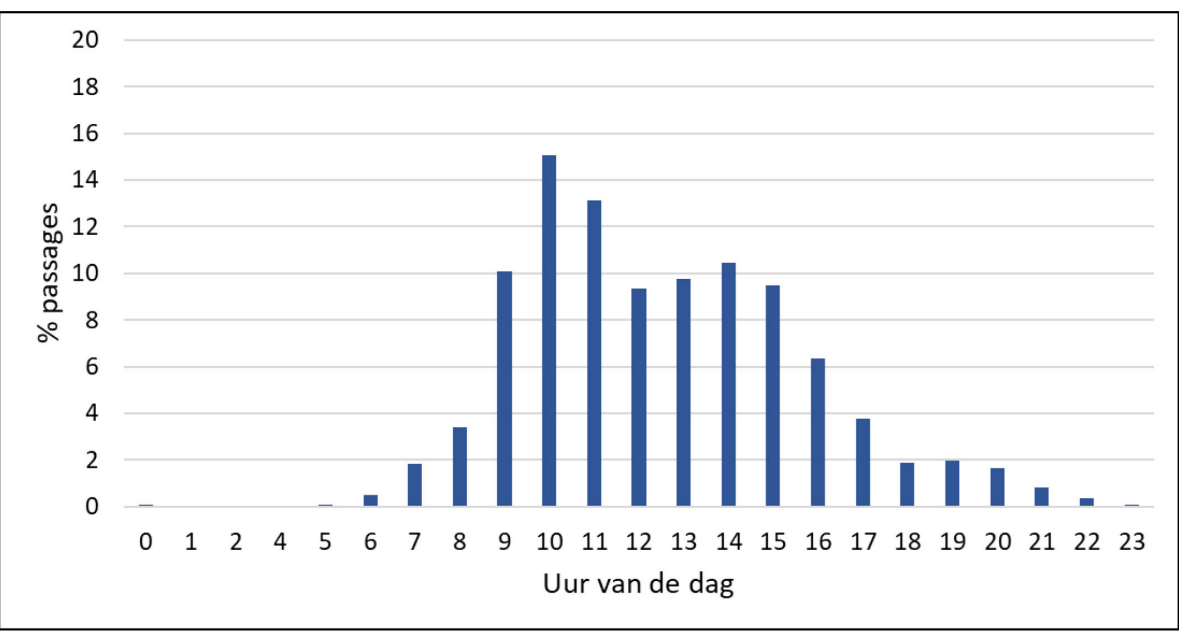

Figuur 47 Proportionele verdeling van het aantal mensen over het etmaal. 
Er zijn enkele beperkingen gesteld aan het gebruik van de natuurbrug door mensen. De natuurbrug is verboden voor brommers, scooters en motoren. Daarnaast is de natuurbrug alleen voor mensen opengesteld tussen zonsopgang en zonsondergang. En ten slotte is betreding van de natuurzone aan de oostzijde van de natuurbrug door mensen verboden. Tijdens de onderzoeksperiode is naar schatting 2.690 maal op illegale wijze gebruikgemaakt van de natuurbrug (Figuur 48 ). Dit is $4,1 \%$ van het totale gebruik door mensen. Brommers/scooters passeren naar schatting gemiddeld 67 maal per jaar $(0,1 \%)$. Passages na zonsondergang vinden naar schatting gemiddeld 2.357 maal per jaar plaats $(3,6 \%)$. Betreding van de natuurzone waar medegebruik niet is toegestaan, gebeurt naar schatting gemiddeld 75 maal per jaar $(0,1 \%)$.
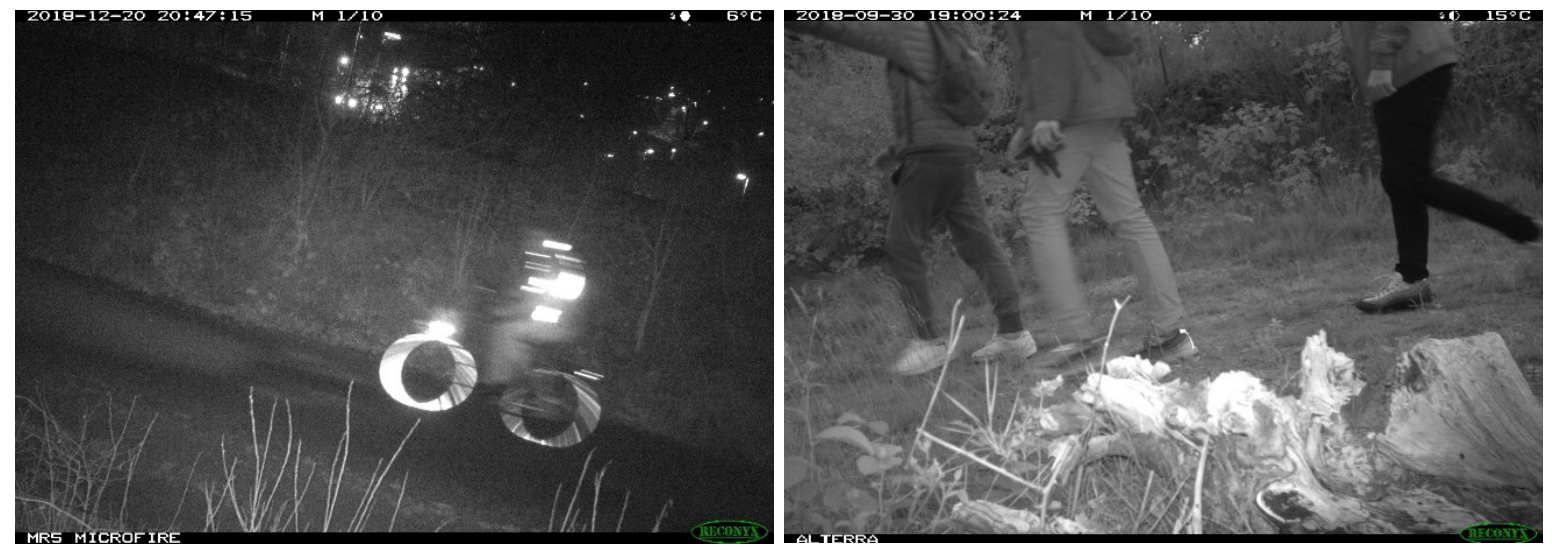

Figuur 48 Hoewel de natuurbrug na zonsondergang verboden terrein is, passeren er dan nog regelmatig mensen via het fiets-/voetpad (links). Ook in de natuurzone zonder menselijk medegebruik passeren regelmatig mensen, hoewel dit verboden gebied is (rechts).

Betreding van de verboden natuurzone door mensen vindt niet gelijkmatig over het jaar plaats (Figuur 49). Het is onder meer afhankelijk van 'dagelijkse routines' van een beperkt aantal mensen. Zo betreffen de meeste passages in 2018 een kleine groep mensen die regelmatig in de avonduren de brug met de honden passeerde. De piek in maart 2019 is veroorzaakt door enkele grotere groepen mensen die passeerden.

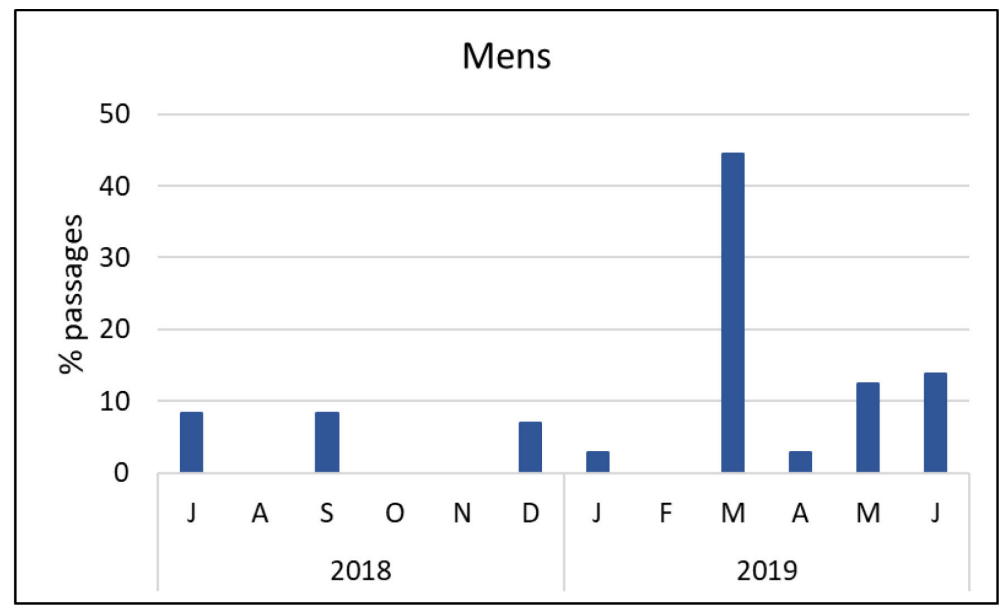

Figuur 49 Procentuele verdeling van het aantal passages van mensen over het jaar in de natuurzone zonder menselijk medegebruik van de natuurbrug. 


\subsection{Gebruik van de natuurbrug door huisdieren}

Op de natuurbrug zijn twee soorten huisdieren waargenomen: hond en huiskat (Figuur 50).
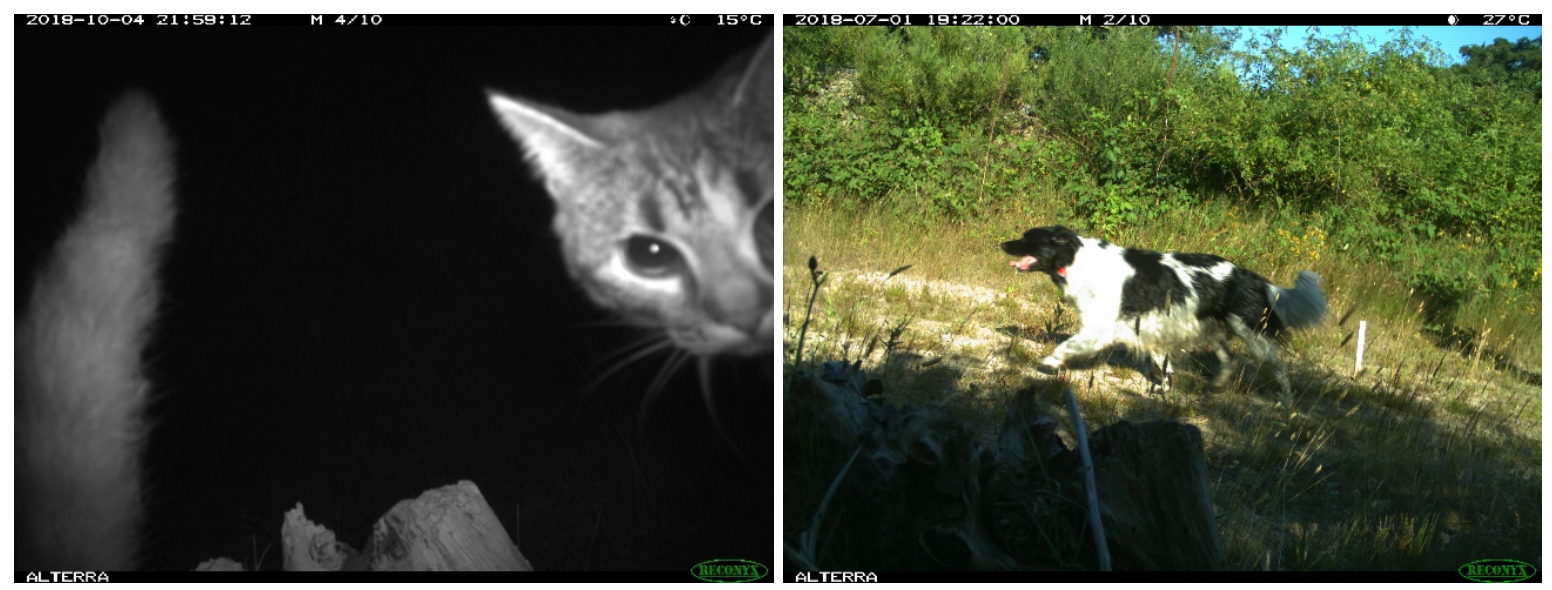

Figuur 50 Twee huiskatten bewonderen de cameraval in de stobbenwal (links). Honden zijn regelmatig op de natuurbrug aangetroffen, ondanks dat het voor dit huisdier gesloten gebied is.

\section{Hond}

Het aantal keer dat een hond tijdens het onderzoeksjaar de natuurbrug is gepasseerd, is geschat op 246. De gemiddelde passagefrequentie van honden is daarmee 1 per dag, 5 per week en 20 per maand. $13 \%$ van de honden passeert via de natuurzone zonder menselijk medegebruik. Het aantal honden is $0,4 \%$ van het aantal mensen dat passeert. Het percentage mensen dat passeert met een hond ligt in werkelijkheid iets lager, omdat het ook regelmatig voorkomt dat iemand met meerdere honden passeert.

Gebruik van de natuurzone zonder menselijk medegebruik door honden vindt niet gelijkmatig over het jaar plaats (Figuur 51). Dit is niet vreemd, omdat het gebruik door honden gerelateerd is aan dat door mensen. Na relatief veel passages in de eerste maand van het onderzoek en relatief weinig in de negen daarop volgende maanden, neemt het relatieve aantal passages in de laatste twee maanden weer toe.

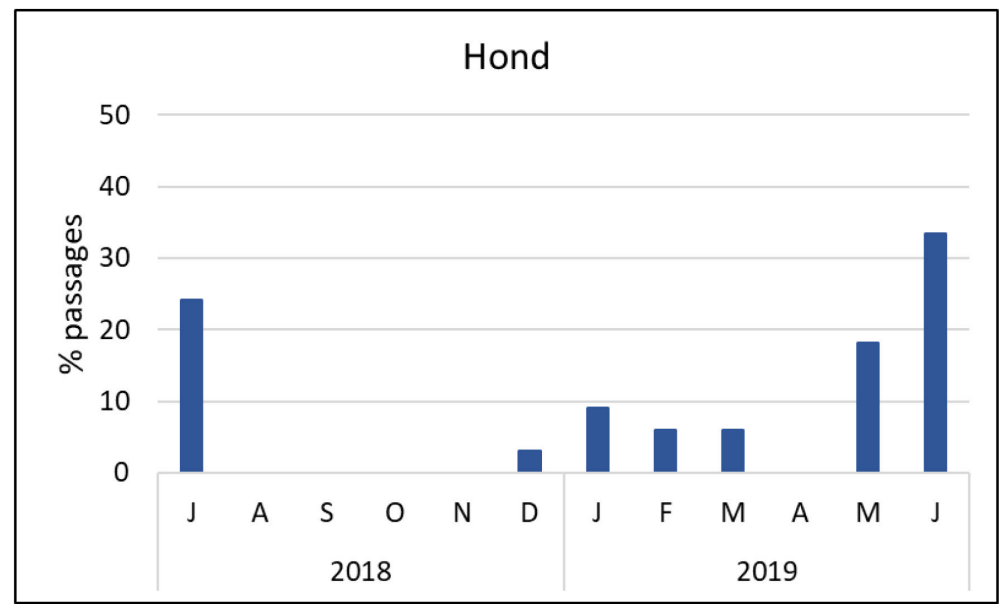

Figuur 51 Procentuele verdeling van het aantal passages van honden over het jaar in de natuurzone zonder menselijk medegebruik van de natuurbrug.

De meeste honden die de natuurbrug passeren (69\%), zijn niet aangelijnd (Figuur 52). In de natuurzone met menselijk medegebruik is dit $52 \%$, terwijl het in de natuurzone zonder menselijk 
medegebruik $100 \%$ is. Bij een vergelijking met de omgeving is te zien dat de proportie loslopende honden op de natuurbrug circa $20 \%$ lager ligt dan in de omgeving.

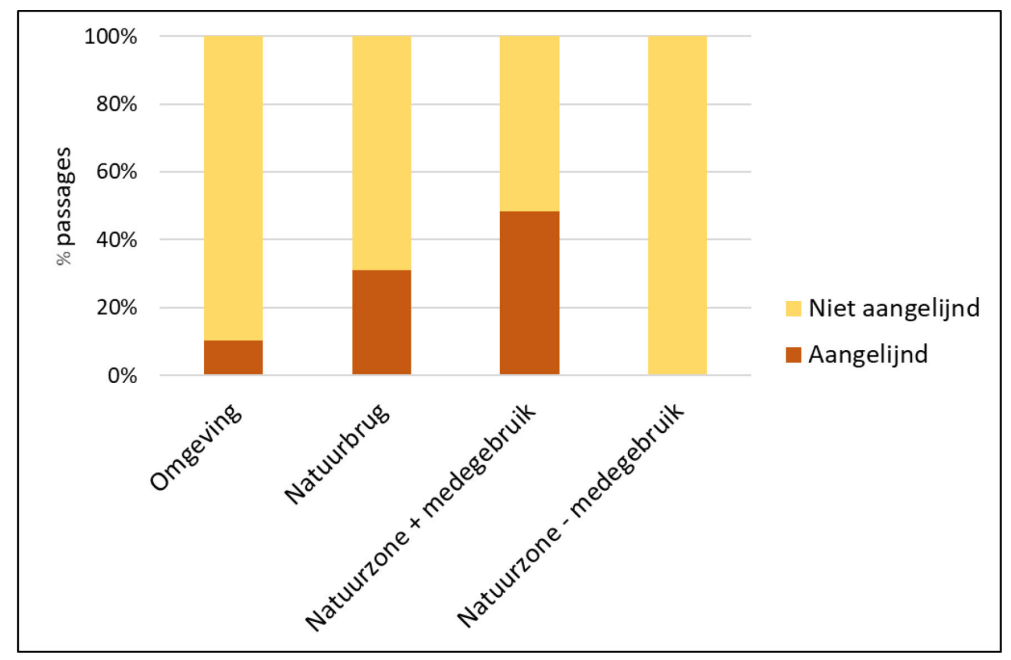

Figuur 52 Procentuele verdeling van het aantal passages van aangelijnde en loslopende honden over het jaar in de omgeving en op de natuurbrug, waarbij voor de natuurbrug ook nog de uitsplitsing is gemaakt tussen de natuurzones met en zonder menselijk medegebruik.

\section{Huiskat}

Het aantal keer dat een huiskat tijdens het onderzoeksjaar de natuurbrug is gepasseerd, is geschat op 123. De gemiddelde passagefrequentie van huiskatten is daarmee 0,3 per dag, 2 per week en 10 per maand. $97 \%$ van de huiskatten passeert via de natuurzone zonder menselijk medegebruik.

Gebruik van de natuurzone zonder menselijk medegebruik door katten vindt niet gelijkmatig over het jaar plaats (Figuur 53). De eerste huiskatten zijn in oktober en november waargenomen. In december-januari is de huiskat niet geregistreerd. Relatief veel passages vonden vervolgens plaats in februari-maart, waarbij regelmatig ook meerdere dieren tegelijkertijd van de brug gebruikmaakten. In de laatste drie maanden van het onderzoek is de huiskat relatief weinig gepasseerd.

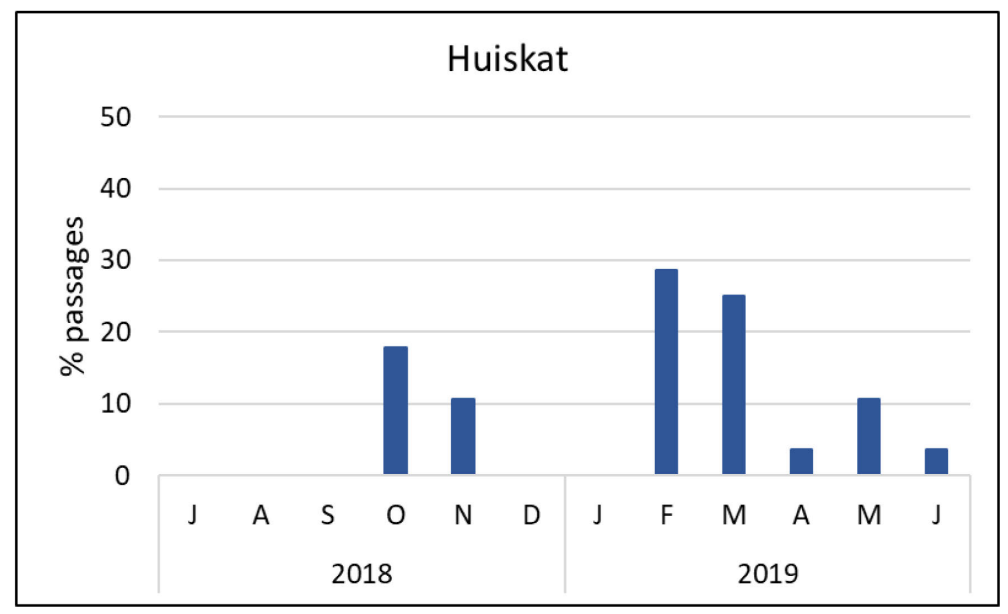

Figuur 53 Procentuele verdeling van het aantal passages van huiskatten over het jaar in de natuurzone zonder menselijk medegebruik van de natuurbrug. 


\subsection{Vergelijking natuurbrug en omgeving}

Wanneer we het illegale gebruik van de natuurzone zonder menselijk medegebruik door mensen vergelijken met illegale betreding van bos- en heidepercelen in de omgeving, zien we dat dit gebruik op de brug een factor 7 hoger is (Figuur 54). Voor hond en huiskat is het beeld vergelijkbaar; deze dieren zijn relatief vaker aangetroffen op de natuurbrug (in de natuurzone met en zonder medegebruik samen) in vergelijking met de omgeving. Voor deze huisdieren is het gebruik van de brug respectievelijk een factor 9 en 13 hoger.

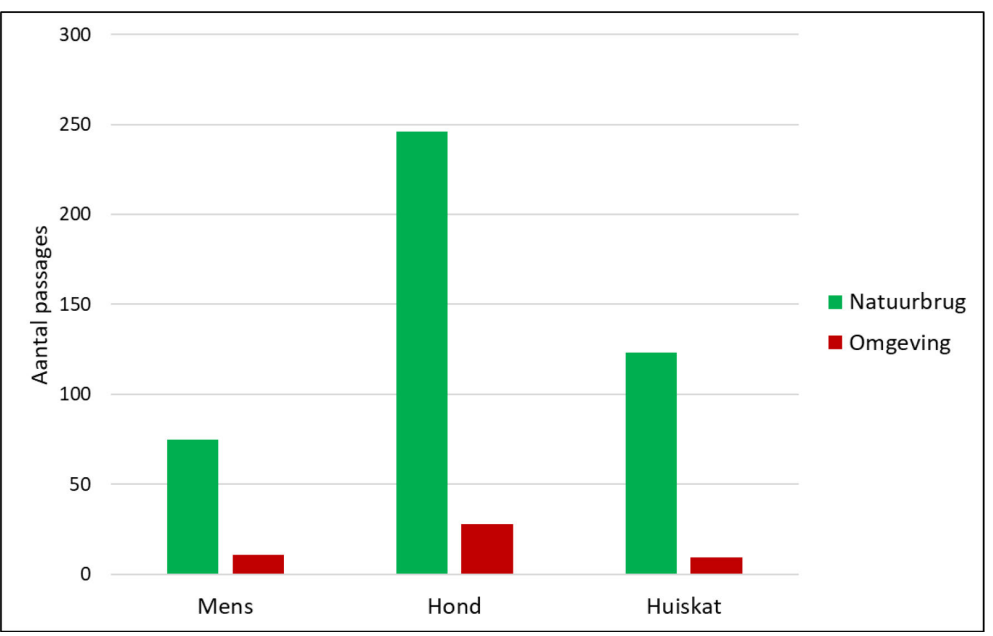

Figuur 54 Het aantal passages per jaar in de natuurzone zonder menselijk medegebruik (mens) en de natuurzone zonder en met menselijk medegebruik samen (hond en huiskat) en op de referentieplekken in de omgeving.

Passages van mensen in de natuurzone zonder menselijk medegebruik zijn geregistreerd tussen 10:00 en 22:00 uur (Figuur 55). Relatief veel passages vonden plaats tussen 15:00 en 16:00, wat te wijten is aan enkele passages van grotere groepen mensen. Daarnaast passeren mensen relatief vaak tussen 19:00 en 21:00 uur, wat te wijten is aan 'vaste avondwandelingen' die sommige maakten. In de omgeving is illegale betreding van percelen relatief vaak tussen 14:00 en 17:00 uur geregistreerd. Een piek in de vroege avond treedt hier niet op.

Honden zijn op de natuurbrug geregistreerd tussen 8:00 en 23:00 uur (Figuur 55). Passages vinden relatief gelijkmatig gedurende de dag plaats, met een dal tussen 17:00 en 19:00 uur, gevolgd door een piek tussen 19:00 en 21:00 uur. Het beeld is voor de omgeving niet veel anders. Een verschil is dat daar vanaf 7:00 uur honden zijn geregistreerd en dat honden na 18:00 uur nauwelijks passeren. Van een piek in de vroege avond is hier dan ook geen sprake.

Huiskatten zijn gedurende het hele etmaal op de natuurbrug geregistreerd (Figuur 55). Relatief de meeste passages vinden echter plaats tussen 18:00 en 23:00 uur en, in enigszins lagere aantallen, tussen 5:00 en 9:00 uur. Ook in de omgeving passeert huiskat gedurende het hele etmaal. Een verschil is dat daar al vanaf 17:00 uur relatief veel dieren zijn geregistreerd en dat er relatief meer passages plaatsvinden in de tweede helft van de nacht. 

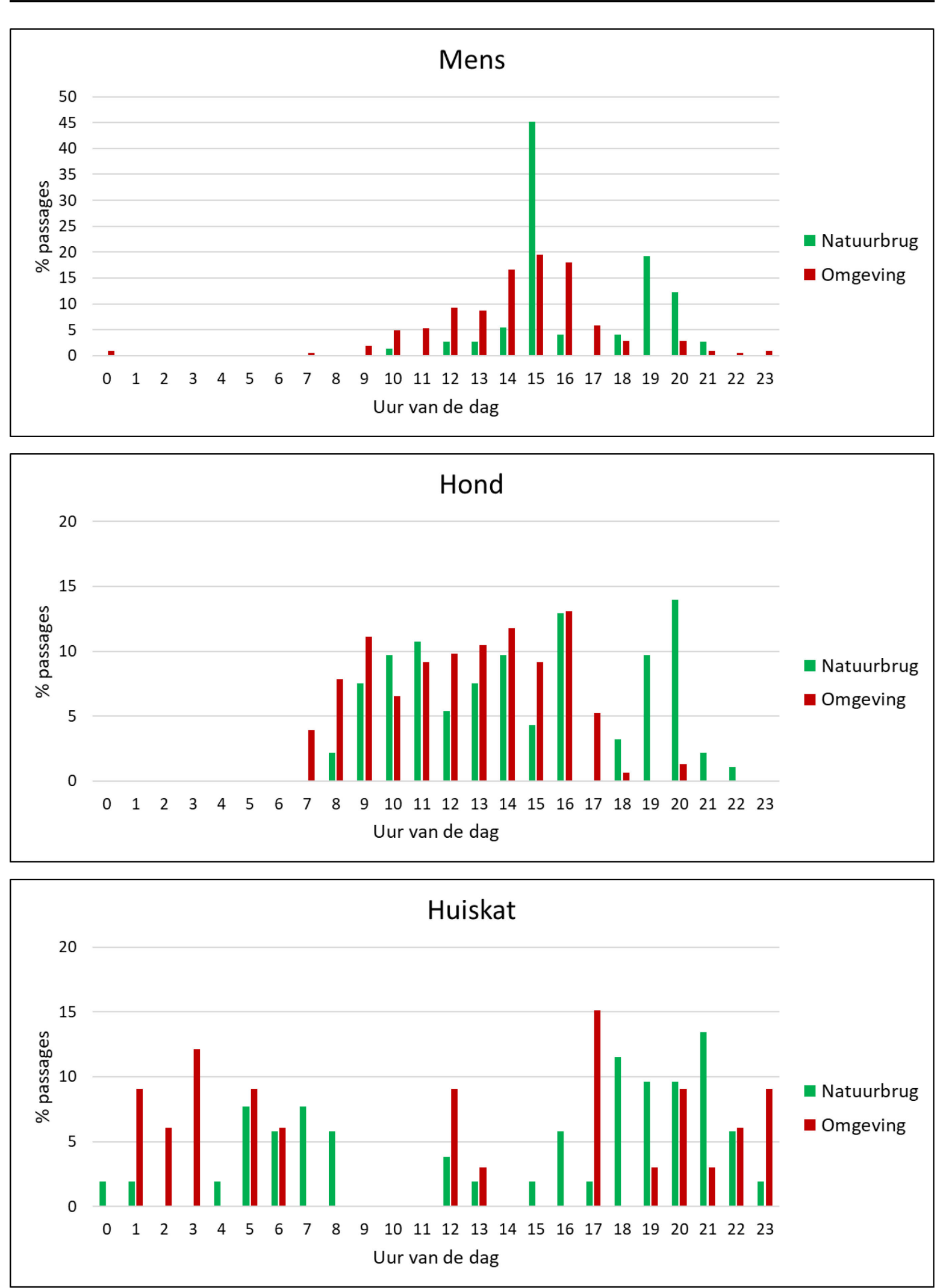

Figuur 55 Procentuele verdeling van het aantal passages per uur van de dag in de natuurzone zonder menselijk medegebruik (mens) en de natuurzone zonder en met menselijk medegebruik samen (hond en huiskat), en op de referentieplekken in de omgeving. 


\section{Effect menselijk medegebruik van de natuurbrug op het gebruik door zoogdieren}

\subsection{Inleiding}

In dit hoofdstuk presenteren we de resultaten van de verkenning naar een eventueel verband tussen het menselijk medegebruik van de natuurbrug en het gebruik ervan door middelgrote zoogdieren. De centrale onderzoeksvraag is: Wat is het effect van het menselijk medegebruik op het gebruik van de natuurbrug door middelgrote zoogdieren?

\subsection{Aantal mensen en aantal dieren}

Voor ree en alle soorten samen is er sprake van een niet-significante, zeer zwak positieve correlatie tussen het aantal mensen dat op een dag passeert en het aantal dieren dat die dag vanaf 12:00 uur tot 24:00 uur passeert (Tabel 6.1). Datzelfde geldt voor vos en haas, maar voor deze soorten betreft het een niet-significante, zeer zwak negatieve correlatie. Voor al deze soorten moet dan ook geconcludeerd worden dat er geen verband lijkt te bestaan tussen het aantal mensen dat op een dag passeert en het aantal dieren dat passeert vanaf 12:00 uur tot middernacht. Betrekken we ook de passages van zoogdieren die tussen 0:00 en 12:00 uur de volgende dag hebben plaatsgevonden, dan zien we hetzelfde beeld: zeer zwak positieve correlaties voor ree, vos en alle soorten samen, en een zeer zwakke negatieve correlatie voor haas (Tabel 6.2; Figuur 56). Geen van deze correlaties is significant. Voor al deze soorten moet dan ook geconcludeerd worden dat er geen verband lijkt te bestaan tussen het aantal mensen dat op een dag passeert en het aantal dieren dat passeert vanaf 12:00 uur tot 12:00 uur de volgende dag.

Tabel 6.1 De Pearson's Correlation Coëfficiënt voor het aantal mensen dat op een dag passeert en het aantal dieren dat die dag tussen 12:00 en 24:00 uur passeert, per soort en voor alle soorten samen.

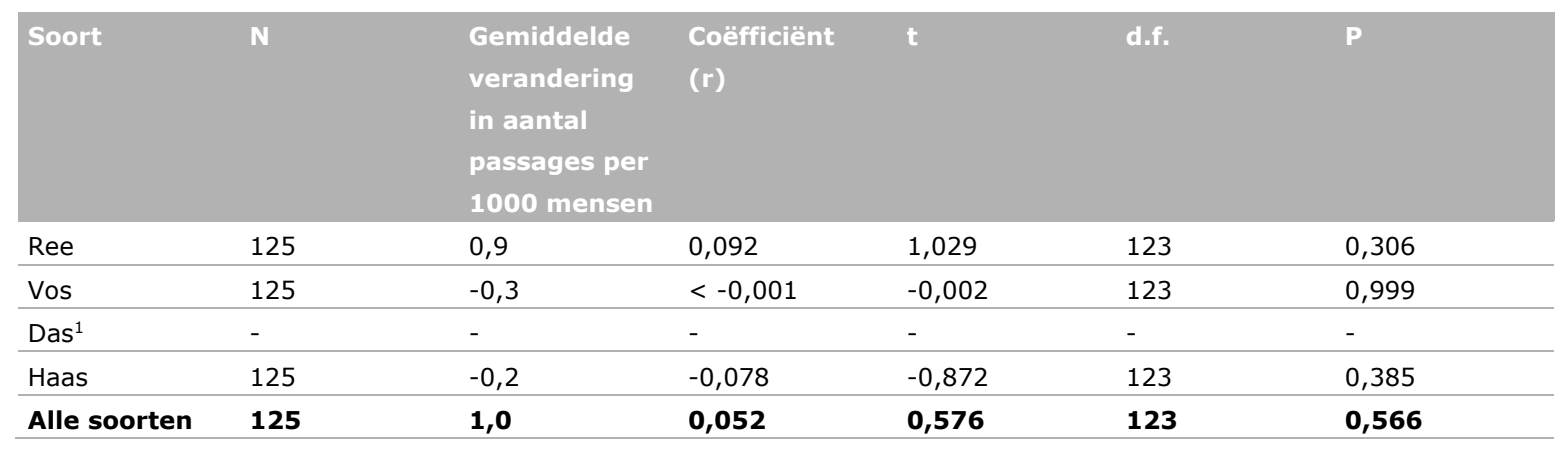

1 Onvoldoende data voor een correlatieberekening. 
Tabel 6.2 De Pearson's Correlation Coëfficiënt voor het aantal mensen dat op een dag passeert en het aantal dieren dat die dag tussen 12:00 en 24:00 uur en de volgende dag tussen 0:00 en 12:00 uur passeert, per soort en voor alle soorten samen.

\begin{tabular}{|c|c|c|c|c|c|c|}
\hline Soort & $\mathbf{N}$ & $\begin{array}{l}\text { Gemiddelde } \\
\text { verandering } \\
\text { in aantal } \\
\text { passages per } \\
1000 \text { mensen }\end{array}$ & $\begin{array}{l}\text { Coëfficiënt } \\
\text { (r) }\end{array}$ & $\mathbf{t}$ & d.f. & $\mathbf{P}$ \\
\hline Ree & 125 & 1,9 & 0,071 & 0,787 & 123 & 0,433 \\
\hline $\operatorname{Das}^{1}$ & - & - & - & - & - & - \\
\hline Haas & 125 & 0,6 & $-0,057$ & $-0,628$ & 123 & 0,531 \\
\hline Alle soorten & 125 & 1,3 & 0,070 & 0,773 & 123 & 0,441 \\
\hline
\end{tabular}

${ }^{1}$ Onvoldoende data voor een correlatieberekening.
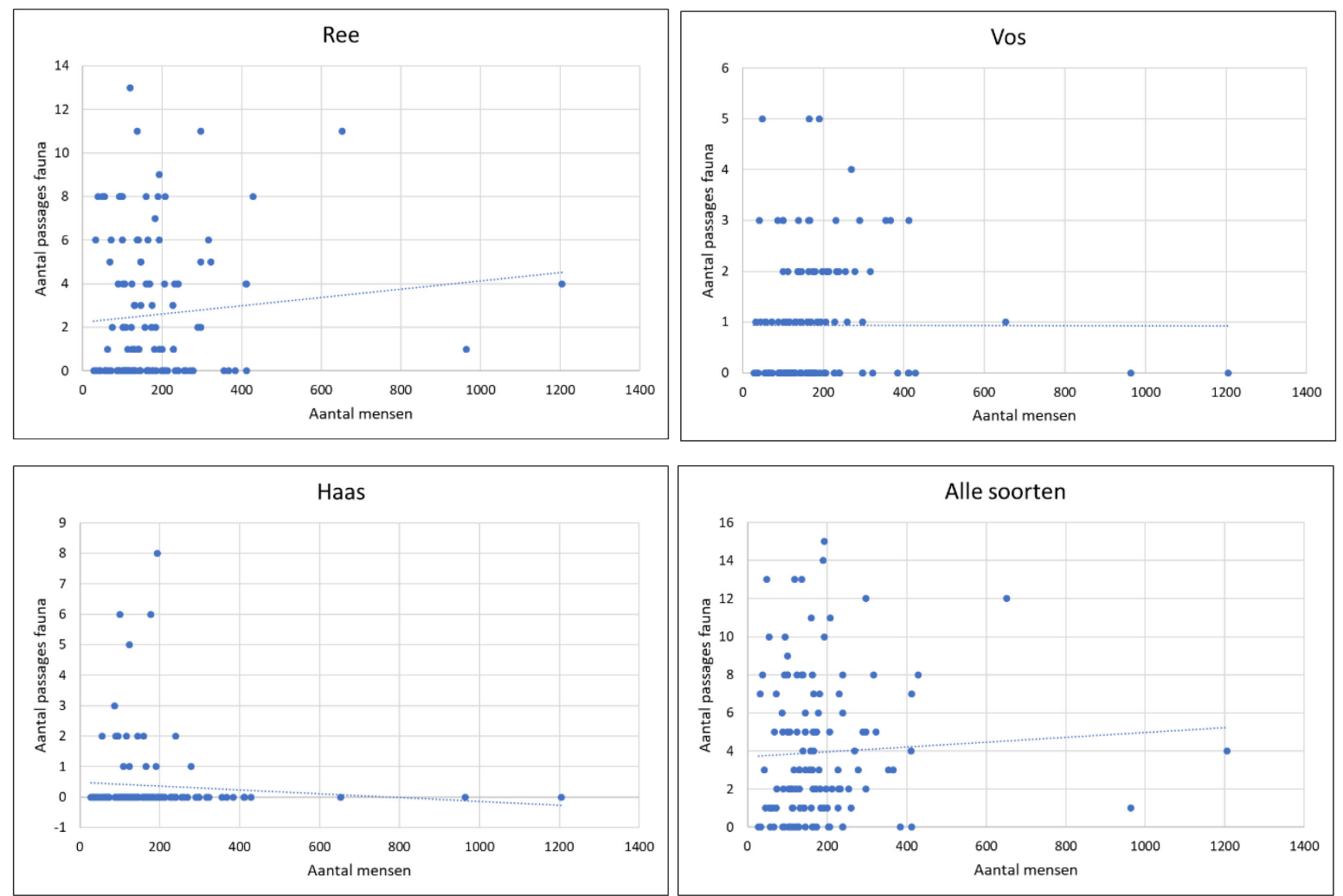

Figuur 56 Het aantal passages op een dag tussen 12:00 uur en 12:00 uur de volgende dag van middelgrote zoogdieren als functie van het aantal passages van mensen op een dag, per soort en voor de soorten ree, vos, das en haas samen.

\subsection{Aantal mensen en het tijdstip waarop dieren passeren}

Voor ree is er sprake van een significante, zwak positieve correlatie tussen het aantal mensen dat op een dag passeert en het tijdstip waarop de dieren die dag vanaf 12:00 uur tot 24:00 uur passeren (Tabel 6.3; Figuur 57). Voor alle soorten samen is eveneens een significante correlatie gevonden, maar deze is zeer zwak of verwaarloosbaar. De significantie is hier vooral een gevolg van het relatief hoge aantal reeën in de steekproef. Voor vos is er sprake van een niet-significante, zeer zwak negatieve correlatie. Voor haas is er sprake van een niet-significante, zwak positieve correlatie. Voor vos en haas moet dan ook geconcludeerd worden dat er geen verband lijkt te bestaan tussen het aantal mensen dat op een dag passeert en het tijdstip waarop de dieren passeren. Voor ree is een dergelijk verband, hoewel zwak, er wel. 
Tabel 6.3 De Pearson's Correlation Coëfficiënt voor het aantal mensen dat op een dag passeert en het tijdstip waarop dieren die dag passeren tussen 12:00 en 24:00 uur, per soort en voor alle soorten samen.

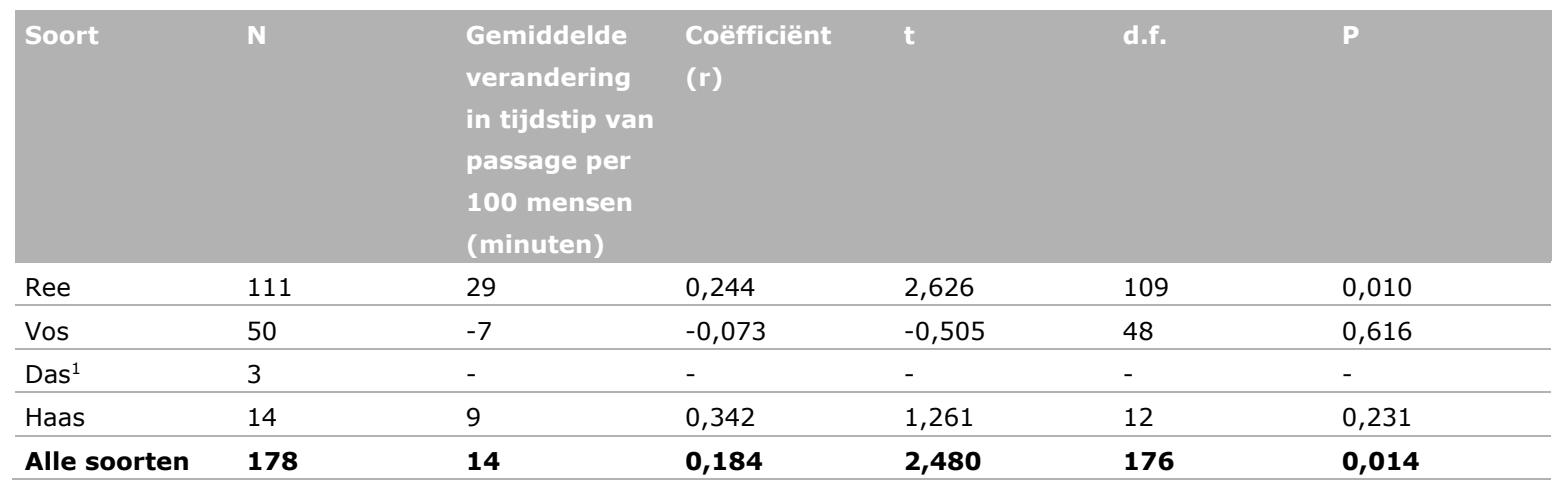

1 Onvoldoende data voor een correlatieberekening.
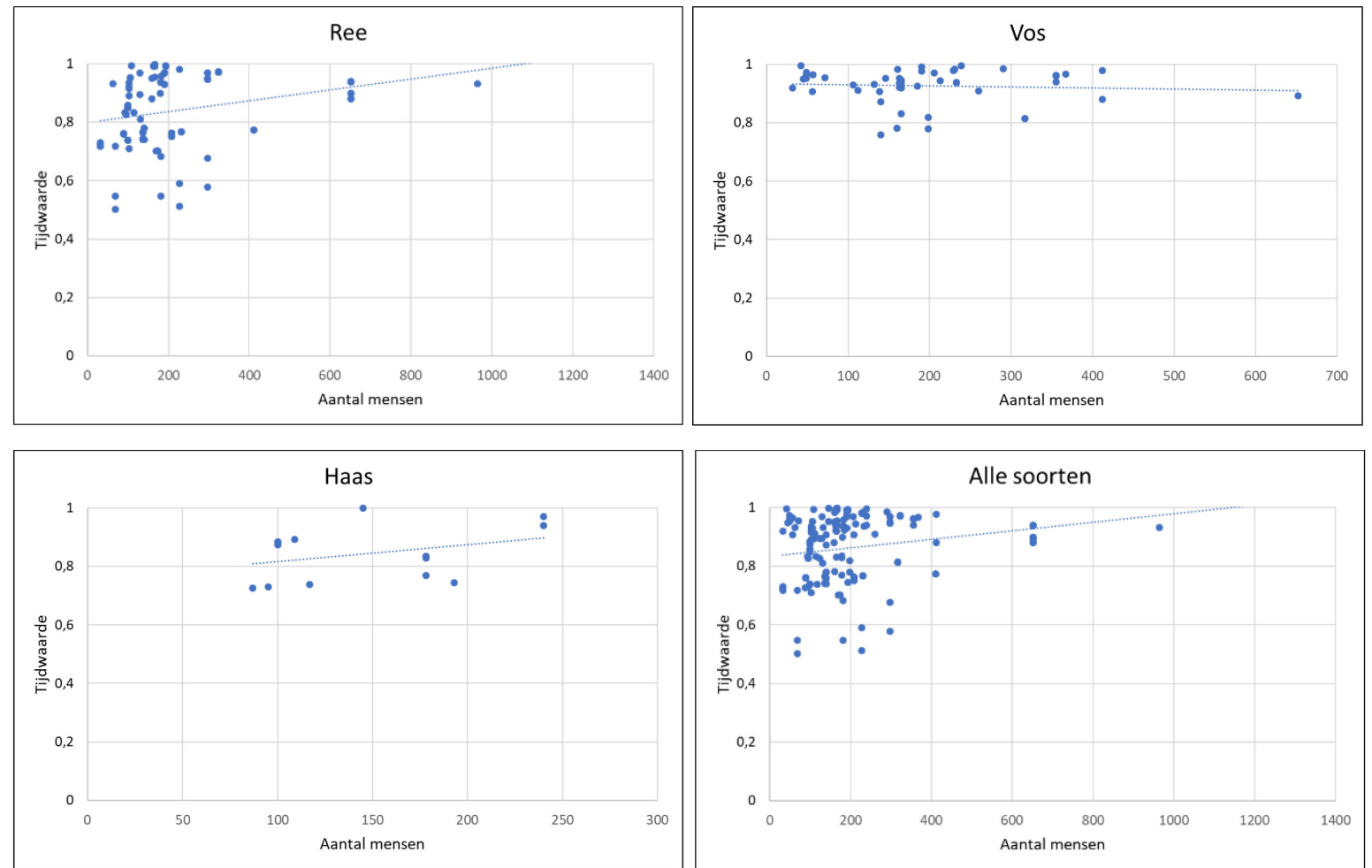

Figuur 57 Het tijdstip van passeren tussen 12:00 en 24:00 uur van middelgrote zoogdieren als functie van het aantal passages van mensen op een dag, per soort en voor de soorten ree, vos, das en haas samen.

\subsection{Voorspellende warde}

Alleen voor ree is een significante, (minimaal) zwak positieve correlatie gevonden tussen het aantal mensen dat op een dag passeert en het tijdstip waarop de dieren tussen 12:00 uur en 24:00 uur passeren. Uit een lineaire regressieanalyse blijkt dat het gevonden verband slechts circa $5 \%$ van de variatie in de data verklaart $\left(r^{2}=0,051 ; t=2,63 ; d f=109 ; p=0,01\right)$. Dit betekent dat grote voorzichtigheid moet worden betracht om het gevonden verband - dat kan worden beschreven met de vergelijking $Y=0,000187 * X+0,7087$ - te gebruiken om het effect van menselijk medegebruik van de natuurbrug op het tijdstip van passeren van reeën te voorspellen. Zeer indicatief kan worden gesteld dat met iedere toename van 100 passerende mensen op een dag, reeën het gebruik van de natuurbrug met circa een halfuur uitstellen. 


\subsection{Drukke versus rustige dagen}

De vergelijking tussen drukke en rustige dagen is alleen voor ree gemaakt en dan uitsluitend voor het tijdstip van passeren tussen 12:00 en 24:00 uur. Voor de overige soorten en onderzochte variabelen zijn immers geen significante, minimaal zwakke correlaties gevonden. Voor ree is er een significant verschil tussen het gemiddelde tijdstip van passeren op drukke dagen in vergelijking met rustige dagen $(t=-3,90 ; d f=45 ; p<0,001)$. Op rustige dagen passeren de dieren gemiddeld om 18:30 uur. Op drukke dagen passeren de dieren gemiddeld bijna drie uur later, om 21:17 uur.

\subsection{Alternatieve verklaringen}

Het aantal mensen dat de natuurbrug passeert, varieerde nauwelijks gedurende de maanden dat in de zone met medegebruik is gemeten (Figuur 58). Het was dus niet zo dat met het korter worden van de dagen, het aantal mensen dat de brug gebruikte, afnam. Dit beeld komt ook naar voren bij correlatie van het aantal mensen dat de natuurbrug gebruikte en de daglengte (Figuur 59). Er is geen correlatie tussen beide gevonden ( $r=0,009 ; t=0,099 ; d f=123 ; p=0,921)$ en daarmee is daglengte verworpen als eventuele alternatieve verklaring voor het gevonden verband tussen het aantal mensen dat passeert en het tijdstip waarop ree de natuurbrug gebruikt.

250

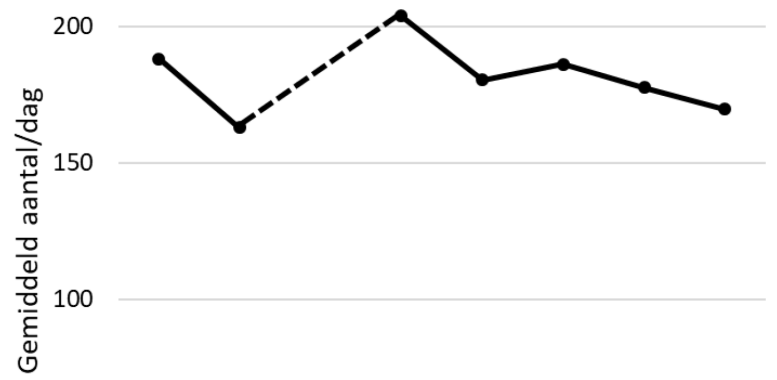

50

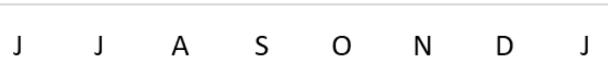

Figuur 58 Het gemiddelde aantal passages van mensen per dag over de natuurbrug in de maanden dat de recreatiezone is gemonitord, inclusief de testmaand (juni 2018).

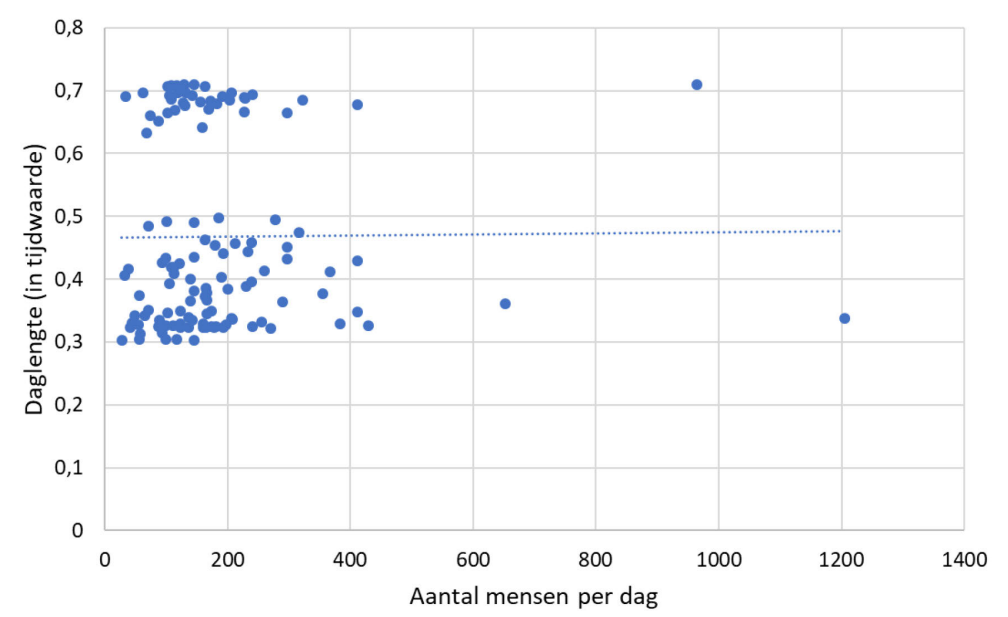

Figuur 59 De daglengte als functie van het aantal passages van mensen op een dag. 


\section{Gebruik Corridor Prinses Julianalaan}

\section{$7.1 \quad$ Inleiding}

In dit hoofdstuk presenteren we de resultaten van de monitoring van Corridor Prinses Julianalaan. De onderzoeksvraag is tweeledig: maken middelgrote zoogdieren gebruik van deze natuurverbinding, en hoe frequent is dan dit gebruik? Omdat de corridor is opengesteld voor publiek - en een gecombineerd wandel-/ruiterpad omvat -, beschrijven we eerst kort de aard en omvang van het menselijk gebruik.

\subsection{Gebruik door mens en huisdier}

Tijdens het onderzoeksjaar is de corridor naar schatting ruim 28.000 keer door mensen gebruikt. ${ }^{3}$ De gemiddelde passagefrequentie van mensen is dan 78 per dag, 546 per week en 2.366 per maand. De meeste mensen passeren te voet (49\%), gevolgd door fietsers (46\%) en ruiters (5\%). Andere manieren van passeren vormen slechts $0,2 \%$ van het totaal. Dit betekent dat er dagelijks gemiddeld 38 voetgangers, 36 fietsers en 4 ruiters passeren. Het aantal keer dat een hond tijdens het onderzoeksjaar de corridor is gepasseerd, is geschat op 1.543. De gemiddelde passagefrequentie van honden is daarmee 4 per dag, 30 per week en 129 per maand. De meeste honden die de corridor passeren (92\%), zijn niet aangelijnd. Het aantal keer dat een huiskat tijdens het onderzoeksjaar de corridor is gepasseerd, is geschat op 10 dus circa eenmaal per maand.

\subsection{Gebruik door zoogdieren}

Tijdens het onderzoek is het gebruik van de natuurverbinding door drie middelgrote zoogdieren vastgesteld. Het betreft de doelsoort ree, en daarnaast vos en haas (Figuur 60, 61 en 62). In totaal zijn er tijdens de 156 dagen dat hier gemonitord is 242 passages van deze middelgrote zoogdieren geregistreerd.

\subsection{Frequentie van passages}

Het totaalaantal passages van middelgrote zoogdieren tijdens de onderzoeksperiode van een jaar is geschat op 987 dieren (Tabel 7.1). Dit betekent dat er gemiddeld 2-3 dieren per dag passeren, circa 19 per week en circa 82 per maand. Er zijn echter verschillen tussen de soorten. Van de drie waargenomen soorten passeren ree en vos in min of meer vergelijkbare aantallen, gemiddeld circa negenmaal per week. Haas passeert gemiddeld veel minder frequent, namelijk eenmaal per week.

Tabel 7.1 Het geschatte aantal passages in Corridor Prinses Julianalaan gedurende de onderzoeksperiode per soort en voor alle soorten samen, en de gemiddelde passagefrequenties per dag, week en maand.

\begin{tabular}{lllll} 
Soort & $\begin{array}{l}\text { Schatting aantal passages } \\
\text { in de onderzoeksperiode }\end{array}$ & $\begin{array}{l}\text { Gemiddeld aantall } \\
\text { passages/dag }\end{array}$ & $\begin{array}{l}\text { Gemiddeld aantal } \\
\text { passages/week }\end{array}$ & $\begin{array}{l}\text { Gemiddeld aantal } \\
\text { passages/maand }\end{array}$ \\
\hline Ree & 463 & 1,3 & 8,9 & 38,6 \\
\hline Vos & 473 & 1,3 & 9,1 & 39,4 \\
\hline Haas & 51 & 0,1 & 1,0 & 4,3 \\
\hline
\end{tabular}

\footnotetext{
3 Gebaseerd op een steekproef van 110 teldagen in de periode juli-december 2018.
} 


\subsection{Trefkans}

Er zijn verschillen in trefkans tussen de soorten (Figuur 63). De doelsoort ree heeft een trefkans van 16\%. Dit betekent dat deze soort gemiddeld eenmaal per 23 dagen de corridor passeert. Vos heeft de hoogste trefkans: $46 \%$. Deze soort passeert gemiddeld dus eenmaal per 8 dagen. Haas heeft de laagste trefkans: 4\%. Deze soort passeert gemiddeld dus eenmaal per 95 dagen.
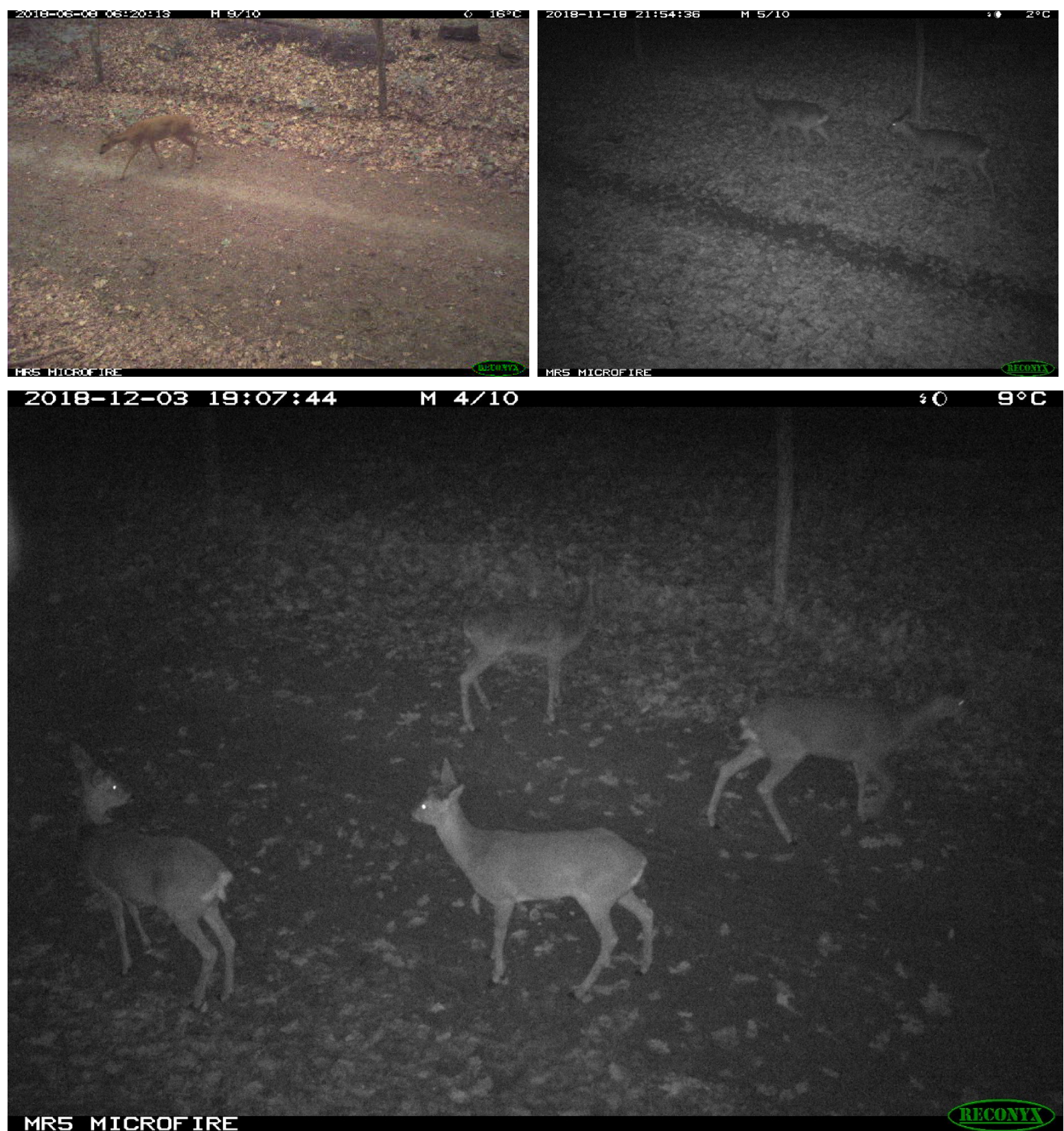

Figuur 60 Een reegeit passeert de corridor bij daglicht in het voorjaar (linksboven); een reebok en -geit passeren in de richting van de Noorderheide (rechtsboven); een groep bestaande uit twee geiten, een bok en een mannelijk kalf passeren de corridor in de vroege avond (onder). 


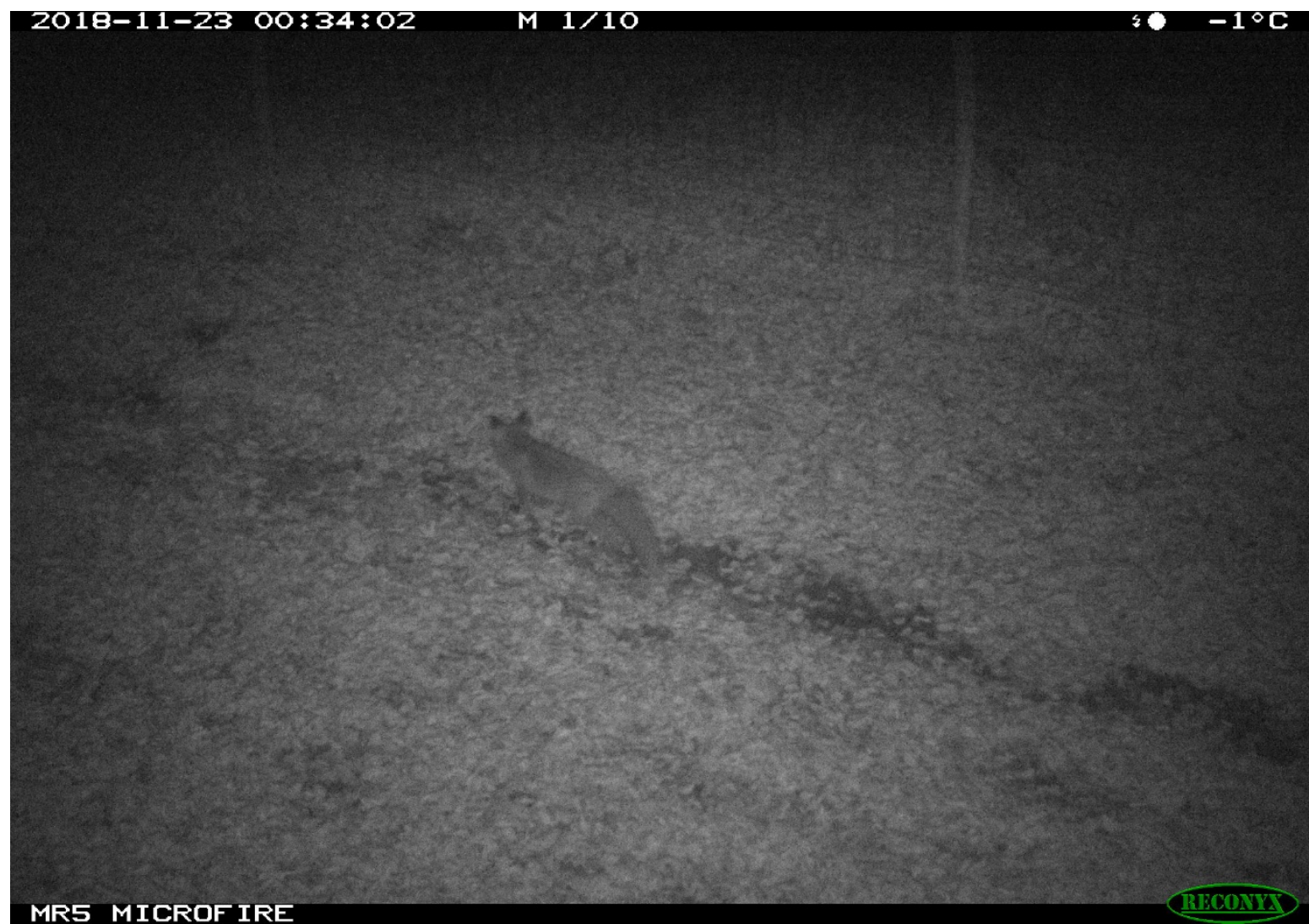

Figuur 61 Een vos passeert de corridor in de richting van de Noorderheide.

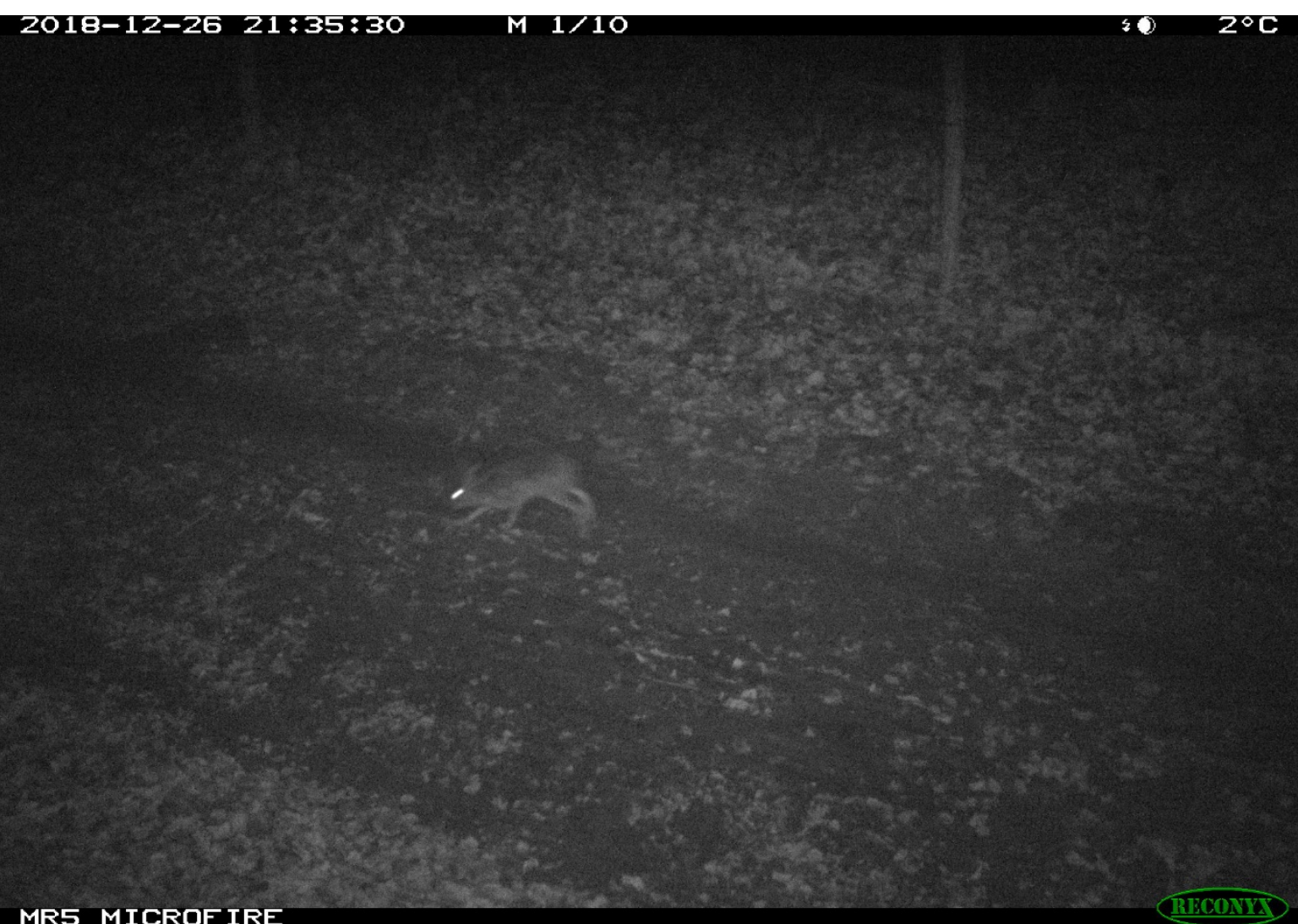

Figuur 62 Een haas passeert de corridor in huppelgang. 


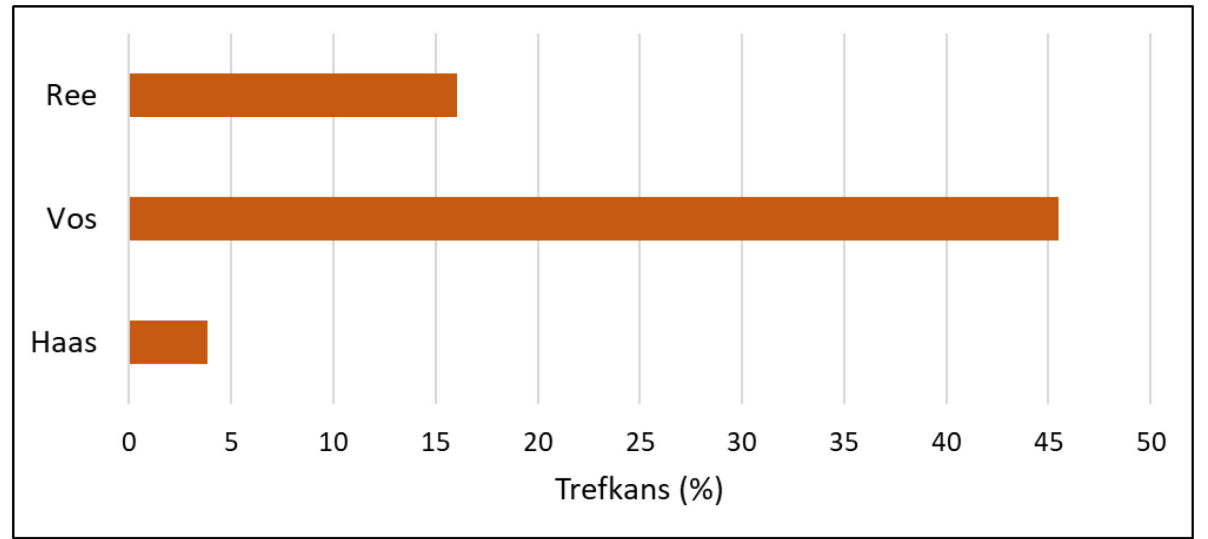

Figuur 63 Trefkans van de soorten in natuurverbinding Corridor Prinses Julianalaan.

\subsection{Passagefrequentie corridor versus omgeving}

De passagefrequenties in natuurverbinding Corridor Prinses Julianalaan van ree en vos zijn groter dan de gemiddelde passagefrequenties in de omgeving (Figuur 64). Het betreft hier een vergelijking met de referentieplekken binnen voor deze soorten geschikte biotopen, onder voorwaarde dat de soort er ook is aangetroffen. Voor deze soorten is er dus sprake van stuwing. Ree heeft een SI van circa 5,5 en voor vos is deze circa 7. Voor haas is er geen - positief dan wel negatief - verschil met de omgeving, met een SI van $-1,1$.

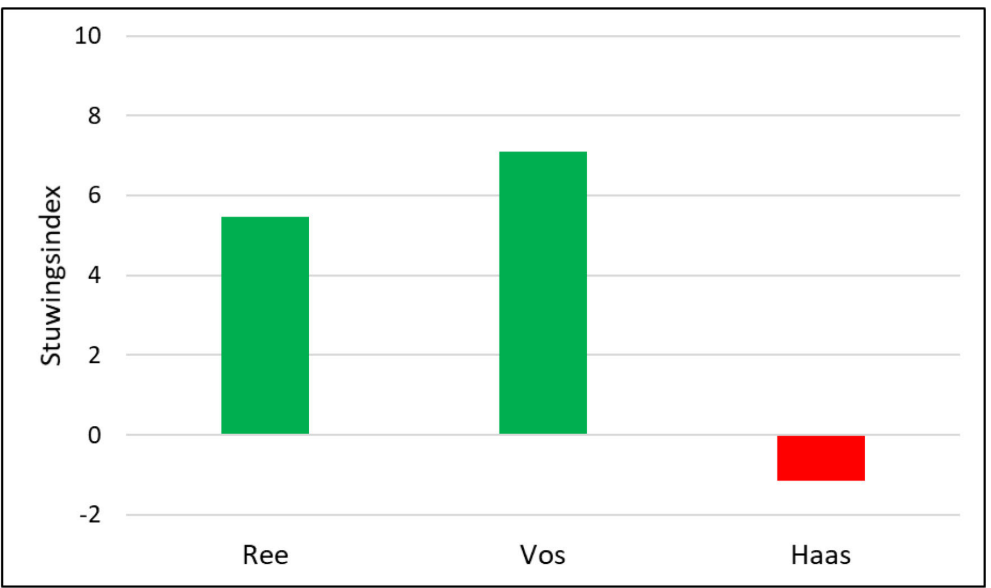

Figuur 64 Stuwingsindex voor de soorten die gebruikmaken van Corridor Prinses Julianalaan, op basis van de gemiddelde passagefrequentie op alle referentieplekken binnen voor de soort geschikte biotoop waar de soort ook is aangetroffen.

\subsection{Discussie}

Vier soorten die wel op de natuurbrug zijn geregistreerd - das, boommarter, bunzing en eekhoorn zijn dus niet waargenomen in Corridor Prinses Julianalaan. Een mogelijke verklaring is dat deze soorten zijn gemist, omdat - door technische problemen - alleen de oostelijke helft van de corridor is gemonitord. Deze soorten hebben wellicht gebruikgemaakt van de beboste westelijke helft, waarbij boommarter en eekhoorn ook via de boomkronen kunnen zijn gepasseerd. Een tweede, o.i. meest waarschijnlijke, verklaring is dat al deze soorten vooral via het naastgelegen bosgebied op Landgoed Larenberg passeren. Het raster dat hier het landgoed begrenst, is immers voor deze soorten geen absolute barrière. 


\section{Gebruik kleine faunatunnels}

\section{$8.1 \quad$ Inleiding}

In dit hoofdstuk presenteren we de resultaten van de monitoring van de kleine faunatunnels onder de Leemzeulder en Boissevainweg. De onderzoeksvraag is tweeledig: maken middelgrote zoogdieren gebruik van deze kleine faunatunnels, en hoe frequent is dan dit gebruik?

\subsection{Leemzeulder}

Gebruik van de twee faunatunnels onder de Leemzeulder door de doelsoorten das en boommarter is niet vastgesteld. Ook andere middelgrote zoogdieren zijn niet in deze tunnels geregistreerd. Wel is frequent - naar verwachting dagelijks - gebruik door bosmuizen waargenomen.

De tunnels onder de Leemzeulder zijn in de winter van 2018/2019 aangelegd en de monitoring heeft hier dan ook maar vijf maanden plaatsgevonden (maart-juni 2019). Dit kan het ontbreken van registraties van middelgrote zoogdieren in deze tunnels wellicht voor een deel verklaren. Een andere mogelijke verklaring is dat dieren die op deze plek de Leemzeulder willen oversteken dat ook over het wegdek kunnen doen. De natuurverbinding is hier namelijk niet over de hele breedte in de rasters gezet: via het voet-/ruiterpad kan de weg worden bereikt. Een derde verklaring kan zijn dat middelgrote zoogdieren, waaronder das en boommarter wellicht vooral via Landgoed Larenberg in noord-zuidrichting en vice versa passeren, en dan dus elders de Leemzeulder oversteken. Deze laatste verklaring wordt ondersteund door het gegeven dat er in Corridor Prinses Julianalaan vooralsnog geen passages van das en boommarter zijn geregistreerd (zie hoofdstuk 7).

\subsection{Boissevainweg}

Gebruik van de zes faunatunnels onder de Boissevainweg door de doelsoorten das en boommarter is niet vastgesteld. Er zijn wel twee andere middelgrote zoogdieren geregistreerd: vos en egel. De vos is vijfmaal gepasseerd, eenmaal via tunnel 4 en viermaal via tunnel 5 (Figuur 65). De egel is eenmaal waargenomen, in tunnel 4. Daarnaast is frequent - naar verwachting dagelijks - gebruik door bosmuizen geregistreerd. De huiskat passeert alle tunnels; in totaal is dit huisdier 21 maal geregistreerd (Figuur 66).
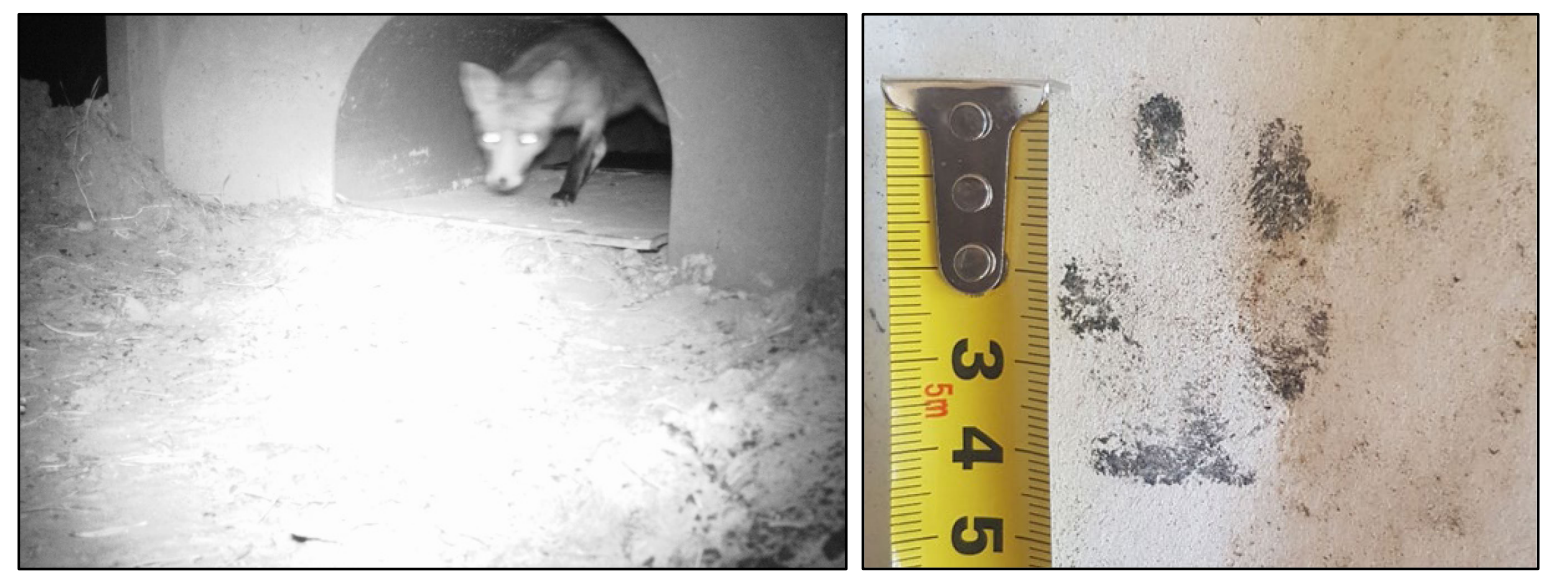

Figuur 65 Een vos passeert een van de kleine faunatunnels onder de Boissevainweg (links) en laat sporen achter op het papier (rechts). 
Een mogelijke verklaring voor het relatief geringe aantal passages van middelgrote zoogdieren door de tunnels onder de Boissevainweg is dat deze kort voor de start van de monitoring zijn aangelegd, in samenhang met aanpassingen aan de weg. In verband met deze werkzaamheden aan de weg is de opgaande bermvegetatie, vooral aan de westkant, verwijderd. Tijdens de onderzoeksperiode was hierdoor niet of nauwelijks geleidende/dekking biedende beplanting rondom de tunnelingangen aanwezig. Naar verwachting spelen ook relatief lage dichtheden van middelgrote zoogdieren op de Blaricummer-heide en Noorderheide een rol. In beide gebieden zijn metingen verricht op een referentieplek (O1 en O3). Op de Blaricummerheide zijn vos, konijn en egel waargenomen. Op de Noorderheide zijn vos, boommarter, haas en eekhoorn geregistreerd. Het aantal waarnemingen van deze soorten is echter relatief gering, aangezien op beide plekken slechts $4 \%$ is waargenomen van de waarnemingen die op alle referentieplekken samen zijn gedaan. Daarbij komt dat beide genoemde referentieplekken in deze natuurterreinen in bosgebied liggen, terwijl de Boissevainweg met tunnels het open heidegebied passeert.
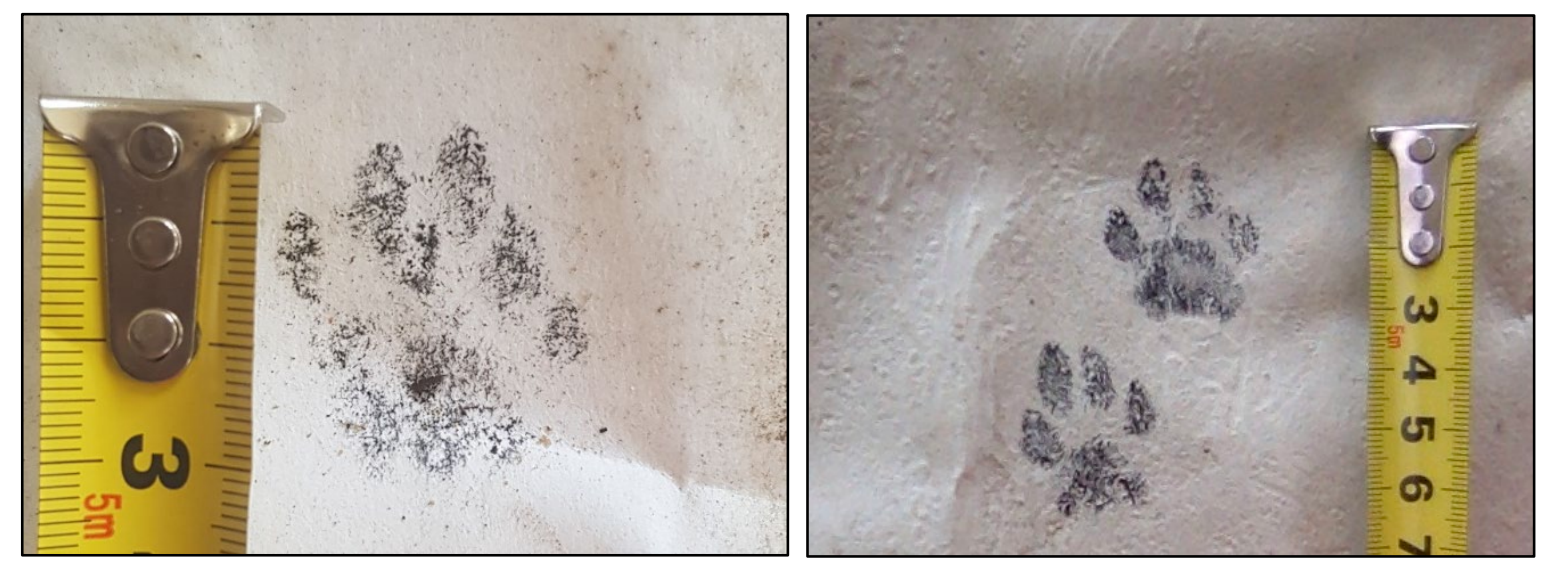

Figuur 66 Sporen van huiskat op de sporenplaten in de kleine faunatunnels onder de Boissevainweg. 


\section{$9 \quad$ Conclusies}

- Natuurbrug Laarderhoogt functioneert in grote lijnen naar verwachting voor de drie doelsoorten ree, das en boommarter. Deze soorten maken alle gebruik van de faunavoorziening. Ree doet dat zeer frequent, gemiddeld tweemaal per dag. De das passeert gemiddeld eenmaal per week en de boommarter eenmaal per twee maanden. Ree en das passeren gemiddeld respectievelijk zeven- en twaalfmaal vaker dan op referentieplekken in de omgeving waar deze soorten zijn aangetroffen. Dit betekent dat er op de natuurbrug sprake is van een stuwingseffect: er passeren meer dieren dan je op basis van toeval mag verwachten. Voor boommarter geldt dit niet. De natuurbrug is dus door de doelsoorten gevonden, geaccepteerd en de vooraf gestelde doelen voor de frequentie van passeren zijn behaald. Dit illustreert dat natuurbruggen ook in sterk verstedelijkte gebieden functioneel kunnen zijn.

- De procentuele verdeling van het aantal passages van ree op de natuurbrug over het jaar wijkt niet sterk af van die in de omgeving. Wat betreft de verdeling van passages over het etmaal zijn er wel duidelijke verschillen. Op de natuurbrug zijn er in de vroege ochtend relatief weinig passages. Aan het begin van de avond is er een toename, maar het grootste deel van de passages vindt pas later in de nacht plaats. Ree passeert de natuurbrug later en vaker in donker in vergelijking met de omgeving. Omdat het aantal waarnemingen op de natuurbrug en/of in de omgeving beperkt was, konden de verdelingen van het aantal passages van das en boommarter over het jaar en over het etmaal niet goed worden vergeleken. Voor boommarter komt het gemiddelde tijdstip van passeren op de natuurbrug overeen met die in de omgeving. Das en boommarter passeerden alleen in donker, zowel op de natuurbrug als in de omgeving.

- Reebokken gebruiken de natuurbrug vaker dan reegeiten. De verhouding adulte versus juveniele dieren verschilt voor deze soort op de natuurbrug niet van die in de omgeving. Het patroon van activiteit van ree over de maanden van het jaar op de natuurbrug verschilt voor zowel bokken, geiten, adulten en juvenielen van het vertoonde activiteitenpatroon in de omgeving. Reeën passeren de natuurbrug vaker in draf of galop. Ook het gedrag dat deze doelsoort op de natuurbrug vertoont, verschilt van dat in de omgeving. Op de brug wordt minder stilgestaan en minder gefoerageerd. De das is de natuurbrug vooral in draf gepasseerd. Boommarter neigt naar meer sluipgang op de natuurbrug in vergelijking met de omgeving. Beide marterachtigen lieten geen grote verschillen in gedrag zien bij een vergelijking tussen natuurbrug en omgeving. De gevonden verschillen voor ree tussen natuurbrug en omgeving wat betreft tijdstip van passeren, indiceren dat deze dieren de natuurbrug ervaren als een 'andere plek dan elders'. Zij passen hun gedrag aan door onder meer later en sneller te passeren en minder te foerageren.

- Gebruik van de natuurbrug is, naast genoemde doelsoorten, ook vastgesteld voor vos, bunzing, haas en eekhoorn. Twee soorten - konijn en egel - die zijn geregistreerd in de omgeving, zijn niet waargenomen op de natuurbrug. Vos en haas passeren frequent, gemiddeld een- tot tweemaal per dag. De bunzing passeert incidenteel, respectievelijk eenmaal in de twee tot drie weken. De eekhoorn passeert zeer incidenteel, gemiddeld eenmaal per tien maanden. Ook voor vos, bunzing en haas is sprake van stuwing. De eekhoorn - de soort die slechts tweemaal op de natuurbrug is geregistreerd - lijkt de natuurbrug nog te mijden. Voor al deze soorten zien we de trend dat ze de natuurbrug gemiddeld later passeren dan op de referentieplekken in de omgeving. Voor bunzing is dit minder dan een halfuur, voor haas is dit bijna anderhalf uur en voor vos en eekhoorn is dit bijna twee uur. Vos en bunzing passeren vooral in donker, haas ook vaak bij daglicht. Vos passeert op de natuurbrug vaker in draf en galop dan in de omgeving. Haas passeert vaker in sprongengalop. Vossen gedragen zich op de natuurbrug anders dan in de omgeving. Ze staan relatief weinig stil, vertonen minder vaak alert gedrag en markeren relatief minder vaak. Voor haas is geen verschil in gedrag gevonden. Voor bunzing en eekhoorn is wat betreft loopwijze en gedrag geen goed vergelijk te maken.

- De natuurbrug wordt frequent gebruikt door mensen. De schatting is dat per jaar 65.000 mensen de natuurbrug passeren, oftewel gemiddeld 179 mensen per dag. Dagelijks passeren gemiddeld 136 fietsers, 38 voetgangers en 4 ruiters. De meeste mensen gebruiken de natuurbrug in het weekend. Binnen het etmaal ligt de piek in het gebruik tussen 10:00 en 12:00 uur. Circa 4\% van 
het gebruik door mensen betreft een niet toegestane vorm van gebruik, i.e. per brommer/scooter, tussen zonsondergang en zonsopgang of via de voor mensen gesloten natuurzone. Illegaal gebruik is er ook door huisdieren. Honden passeren gemiddeld eenmaal per dag. Het grootste deel hiervan is niet aangelijnd. Huiskatten passeren gemiddeld tweemaal per week.

- Voor ree, vos en haas is er geen effect gevonden van het menselijk medegebruik van de natuurbrug op het aantal dieren dat passeert. Voor ree is er wel een verband gevonden tussen de intensiteit van het menselijk gebruik en het tijdstip waarop de dieren passeren. Met iedere toename van 100 passerende mensen op een dag, lijken reeën het gebruik van de natuurbrug met circa een halfuur uit te stellen. Het gevonden verband is echter zwak en heeft dan ook een geringe voorspellende waarde. Voor ree is er een significant verschil tussen het gemiddelde tijdstip van passeren op drukke dagen ( $>250$ mensen) in vergelijking met rustige dagen ( $<100$ mensen). Op rustige dagen passeren de dieren gemiddeld om 18:30 uur. Op drukke dagen passeren de dieren gemiddeld bijna 3 uur later.

- Voor natuurverbinding Corridor Prinses Julianalaan is gebruik door ree, vos en haas vastgesteld. In totaal zijn hier naar schatting bijna duizend passages van middelgrote zoogdieren per jaar, gemiddeld 2-3 dieren per dag. Ree en vos passeren in min of meer vergelijkbare aantallen, gemiddeld circa negenmaal per week. Haas passeert gemiddeld minder frequent, namelijk eenmaal per week. Voor ree en vos is er sprake van stuwing: de passagefrequenties in de natuurverbinding zijn groter dan de gemiddelde passagefrequenties op de referentieplekken in de omgeving. Voor haas is er geen verschil met de omgeving vastgesteld. Das, boommarter, bunzing en eekhoorn zijn niet waargenomen in Corridor Prinses Julianalaan. De meest waarschijnlijke verklaring is dat deze soorten vooral via het naastgelegen bosgebied op Landgoed Larenberg passeren. Het raster dat hier het landgoed begrenst, is immers voor deze soorten geen absolute barrière.

- Voor de faunatunnels onder de Leemzeulder en Boissevainweg is gebruik door de doelsoorten das en boommarter niet vastgesteld. Bij de Boissevainweg zijn wel twee andere middelgrote zoogdieren geregistreerd: vos en egel. De vos is vijfmaal gepasseerd, de egel is eenmaal waargenomen. De huiskat is alle tunnels gepasseerd. 


\section{Aanbevelingen}

\subsection{Adviezen voor inrichting en beheer}

Middelgrote zoogdieren maken vooral gebruik van de natuurzone zonder menselijk medegebruik bij het passeren van de natuurbrug. Gebruik van de natuurzone met menselijk medegebruik, die circa $33 \%$ van de functionele breedte inneemt, door ree, das, boommarter, bunzing en eekhoorn is niet vastgesteld. Vos en haas passeerden hier wel. Vos deed dit naar verhouding met de breedte van de zone, maar passages van haas betrof hier slechts $3 \%$ van het totale aantal passages. Dit betekent dat een relatief groot deel van de functionele breedte van de brug door middelgrote zoogdieren onbenut blijft. De aanbeveling is dan ook om te verkennen of deze zone enigszins kan worden versmald ten gunste van de breedte van de natuurzone zonder menselijk medegebruik.

Boommarter en eekhoorn gebruiken de natuurbrug nog slechts incidenteel. Dit heeft naar verwachting vooral te maken met het ontbreken van hoog opgaande begroeiingen op zowel de natuurbrug als de toelopen. Enerzijds is er gewoon meer tijd nodig om enige bosontwikkeling te krijgen. Maar anderzijds is de aanbeveling om het beheer te evalueren en te zien of er plaatselijk in het beheer meer ruimte kan worden gegeven aan de ontwikkeling van boomvormers, zonder dat hierbij de ontwikkeling van een zone met soortenrijke heidevegetatie in het geding komt.

Niet alle soorten die op de natuurbrug zijn geregistreerd, zijn ook in natuurverbinding Corridor Prinses Julianalaan geregistreerd. Een deel van de soorten, zoals das, boommarter en bunzing, maakt hier naar verwachting gebruik van het naastgelegen bosgebied op Landgoed Larenberg. Hoewel het raster van dit landgoed naar verwachting geen $100 \%$ barrière is voor middelgrote zoogdieren, is het advies om te verkennen of dit raster kan worden verwijderd en het beheer van de natuurverbinding en de aangrenzende strook op het landgoed op elkaar kan worden afgestemd. De aanbeveling is om hier een heidecorridor te ontwikkelen met pleksgewijs open zand en heischraal grasland, die als verbinding kan fungeren tussen de heide op de brug en die op de Noorder- en Blaricummerheide (zie ook Van der Grift et al., 2010).

Aan de zuidkant van de natuurbrug sluit de heidevegetatie van de natuurverbinding nog niet aan op die van de Westerheide. Een circa $300 \mathrm{~m}$ breed bosgebied ligt nu tussen de toeloop van de brug en het noordelijkste heideterrein van de Westerheide, nabij de watertoren. Herinrichting van dit gebied is de aanbeveling, waarbij een mozaïek van open zand, heide, heischraal grasland, struweel/ruigte en gemengd bos het streefbeeld is. Deze omvorming is vooral voor de minder mobiele diersoorten van heide - zoals reptielen en insecten - van belang. Bij de omvorming moet wel een boscorridor tot aan het brugdek over rijksweg A1 worden gehandhaafd/ontwikkeld, zodat het gebruik door sterk aan bos gebonden soorten - zoals boommarter en eekhoorn - wordt bevorderd (zie ook Van der Grift \& Lammertsma, 2017).

Het illegale gebruik van de natuurbrug is relatief groot als we dit vergelijken met bijvoorbeeld het illegale gebruik van Natuurbrug Groene Woud, een ecoduct waar geen menselijk medegebruik is toegestaan. Tijdens monitoring van deze natuurbrug in 2006-2008, is deze gemiddeld door 265 mensen per jaar gebruikt (Van der Grift et al., 2010). Dat is dus circa 10\% van het illegale gebruik dat we hier binnen Natuurverbinding Laarderhoogt hebben gemeten. Het illegale gebruik betreft hier vooral het gebruik van de natuurbrug door mensen (vooral fietsers) na zonsondergang. En betreding van de natuurbrug met een hond. Maatregelen om dit gebruik te beperken in de vorm van fysieke barrières, voorlichting en/of handhaving, zal naar verwachting een positief effect hebben op het gebruik door middelgrote zoogdieren. Het bieden van aantrekkelijke alternatieven voor het wandelen met de hond is ook een optie.

Mede door de aanpassingen die recentelijk aan de Boissevainweg zijn gemaakt, is er weinig beplanting aanwezig rond de tunnelingangen. De aanbeveling is om in circa $25 \mathrm{~m}$ (west) en $15 \mathrm{~m}$ (oost) brede zones langs de weg bos- en struweelvegetaties te ontwikkelen. Deze moeten beweging en licht van de weg afschermen en dieren zowel dekking bieden als geleiden richting de tunnels. Een bijkomend 
voordeel is dat ook voor de recreant op de Blaricummerheide en Noorderheide de Boissevainweg hierdoor uit het zicht verdwijnt. Een tweede aanbeveling is om het dassenraster ter hoogte van de dassentunnels in een trechtervorm te plaatsen, waarbij het in een hoek van circa 45 graden precies aansluit op de ingangen van de tunnels.

De aanbeveling is om het dassenraster aan de noordzijde van Corridor Prinses Julianalaan over de hele breedte van de corridor aan te leggen. Het ontbreken van sporen van middelgrote zoogdieren in de twee faunatunnels onder de Leemzeulder kan immers betekenen dat de dieren hier over het wegdek passeren, met het risico te worden aangereden. Voor de gebruikers van het voet-/ruiterpad in de corridor moet dan een voorziening worden getroffen om het raster te passeren. Het advies is om dit niet in de vorm van een wildrooster, maar in de vorm van een klaphek te doen. Dit heeft als nadeel dat ruiters moeten afstappen, maar daarentegen als voordeel dat ook fietsers niet zomaar de corridor in kunnen rijden. Hiermee kan naar verwachting het (forse) illegale gebruik van Corridor Prinses Julianalaan door fietsers worden teruggedrongen. Een tweede aanbeveling is om het dassenraster in een trechtervorm te plaatsen, waarbij het in een hoek van circa 45 graden precies aansluit op de ingangen van de tunnels.

\subsection{Adviezen voor vervolgonderzoek}

De natuurverbinding is nog in ontwikkeling. De vegetatie op de natuurbrug en de toelopen heeft nog niet volledig het streefbeeld bereikt en zowel in natuurverbinding Corridor Prinses Julianalaan aan de noordzijde als het bosgebied aan de zuidzijde zijn nog geen inrichtingsmaatregelen genomen. Het advies is dan ook om het onderzoek over vijf jaar te herhalen om te onderzoeken hoe het gebruik door middelgrote zoogdieren zich dan heeft ontwikkeld. De aandacht zou daarbij vooral uit moeten gaan naar de soorten die nu nog slechts incidenteel of geen gebruikmaken van de natuurbrug, zoals boommarter, bunzing, eekhoorn, konijn en egel. En dit onderzoek zou opnieuw aandacht moeten hebben voor zowel het gebruik van de natuurbrug zelf als het gebruik van Corridor Prinses Julianalaan en het naastgelegen Landgoed Larenberg.

Wanneer de inrichting van de natuurverbinding is voltooid, dus als alle (her)inrichtingsmaatregelen in de noordelijke corridor en rondom de zuidelijke toeloop zijn genomen, inclusief de herinrichting van CrailoZuid, is het aan te bevelen om ook het gebruik van de natuurverbinding door minder mobiele diersoorten te monitoren, zoals amfibieën, reptielen, dagvlinders, loopkevers en andere ongewervelden. Daarnaast is het advies om het gebruik door vleermuizen te onderzoeken, omdat vooralsnog weinig bekend is over de acceptatie en het gebruik van natuurbruggen in Nederland door deze soort-groep.

$\mathrm{Na}$ aanpassing van het raster langs de Leemzeulder en ontwikkeling van zones met opgaande beplanting en dood hout (stobben, takkenrillen) langs de Boissevainweg is het advies om de kleine fauna-tunnels opnieuw te monitoren. Bij voorkeur met cameravallen, wat op dat moment naar verwachting minder risicovol is, omdat de camera's dan uit het zicht van de weggebruiker kunnen worden opgesteld (wat nu niet het geval was door de wegwerkzaamheden en het verwijderen van veel direct langs de weg aanwezige opgaande begroeiing).

We hebben ons in deze studie vooral gericht op het aantal keer dat een soort de natuurverbinding passeert. Deze aantallen zeggen niet direct iets over het aantal verschillende individuen dat gebruik maakt van de natuurbrug. Groepsgrootte tijdens passage kan hier ook maar heel beperkt licht op werpen. Zo passeerden das, boommarter en eekhoorn altijd alleen. De maximale groepsgrootte tijdens passage voor vos, bunzing en haas was twee. En voor ree is een maximale groepsgrootte van vier dieren geregistreerd. Om een schatting van het aantal verschillende dieren te krijgen, is het nodig dat de dieren individueel kunnen worden herkend. De hier gebruikte onderzoeksmethode - camera-vallen - is hiervoor in veel gevallen ongeschikt. Bij de meeste soorten ontbreken goed herkenbare individuele kenmerken en de beweging van de dieren en kwaliteit van de camerabeelden maken het in veel gevallen ook lastig om eventuele bijzondere kenmerken te zien. Een uitzondering vormt ree, waar man en vrouw goed van elkaar te onderscheiden zijn en met behulp van het gewei ook individuele bokken kunnen worden herkend. Dit biedt de kans om voor deze soort wel een schatting te maken van het aantal individuen dat de brug gebruikt. Het advies is om de huidige dataset te gebruiken om deze analyse uit te voeren. 


\section{Dankwoord}

De auteurs willen allereerst Koosje Lever, Gerlies Nap, Nico Jonker en Belinda van der Kort, allen werkzaam bij de Provincie Noord-Holland, bedanken voor het in ons gestelde vertrouwen, de prettige begeleiding van het onderzoek en het constructief meedenken bij de totstandkoming van zowel het onderzoeksplan als het onderzoeksrapport.

Onze dank gaat ook uit naar Poul Hulzink, John Didderen en Ben Blessing (Goois Natuurreservaat) die het onderzoek vanuit het perspectief van de terreinbeheerder hebben begeleid en ons bij velerlei praktische zaken hebben ondersteund. Dank ook voor de positief-kritische review van de conceptversie van het onderzoeksrapport.

Adam Hofland (Rijkswaterstaat) willen we graag bedanken voor de beschikbaar gestelde financiering welke, samen met de financiering van de provincie en het Goois Natuurreservaat, ervoor zorgde dat het onderzoek mogelijk werd.

De eigenaar van Landgoed Klein Raboes willen we bedanken voor de verleende toestemming om een cameraval op het landgoed te plaatsen.

Ten slotte willen we graag alle studenten bedanken die hebben meegewerkt aan het onderzoek. Dit zijn Emma den Hartog, Linda de Haas, Marja Roorda en Katrijn De Doncker (Hogeschool Van Hall Larenstein - Velp), Anouk Boersma en Nikki Luttjeboer (Hogeschool Van Hall Larenstein Leeuwarden), Tristan Brinkman (Helicon MBO - Velp), Freek Bulten (Aeres MBO - Almere) en Lex van Drongelen (Wageningen Universiteit). Naast de ondersteuning bij het veldwerk was hun inzet zeker onmisbaar bij het analyseren van de tienduizenden fotobeelden die tijdens het onderzoek zijn verkregen! 


\section{Literatuur}

Bergsma-Eijsackers, A. 2006. Onderbouwing natuurverbinding Het Gooi. Grontmij Nederland BV, Alkmaar.

De Keijzer, A., A. Soepboer \& A. Craats. 2013. Monitoring van ecoducten en corridors binnen het programmagebied Hart van de Heuvelrug. CSO Adviesbureau, Bunnik.

Emond, D. \& G.J. Brandjes. 2015. Resultaten monitoring ecoduct Huis ter Heide 2014. Bureau Waardenburg, Culemborg.

Goois Natuurreservaat. 2003. Uitvoeringsplan Ontsnippering 't Gooi. Stichting Gooisch Natuurreservaat, Hilversum.

Goois Natuurreservaat, Stichting Het Utrechts Landschap, Vereniging Natuurmonumenten en Staatsbosbeheer. 2003. Uitvoeringsprogramma noordelijke Heuvelrug. Stichting Gooisch Natuurreservaat, Hilversum.

Goois Natuurreservaat. 2009. Beheervisie en beheerplan 2010-2019. Met hierin opgenomen het beheerplan ex. art. 17 Natuurbeschermingswet voor beschermde natuurmonumenten. Stichting Gooisch Natuurreservaat, Hilversum.

Ministerie van V\&W, Ministerie van LNV \& Ministerie van VROM. 2004. MJPO Meerjarenprogramma Ontsnippering. Ministerie van Verkeer en Waterstaat / Ministerie van Landbouw, Natuur en Voedselkwaliteit / Ministerie van Volkshuisvesting, Ruimtelijke Ordening en Milieubeheer, Den Haag.

Smitskamp, L. 2010. Het gebruik van de ecoducten Leusderheide en Treeker Wissel door middelgrote en grote zoogdieren, met speciale aandacht voor het ree (Capreolus capreolus). Studentenrapport. Vrije Universiteit, Amsterdam.

Van der Grift, E.A., R. Pouwels \& R. Reijnen. 2003. Meerjarenprogramma Ontsnippering Knelpuntenanalyse. Alterra-rapport 768. Alterra, Wageningen.

Van der Grift, E.A. 2006. Natuurbrug Het Gooi. Toetsing plannen voor kantoorbebouwing op voormalig AZC-terrein. Alterra-rapport 1379. Alterra, Wageningen.

Van der Grift, E.A., F.W.G.A Ottburg \& J. Dirksen. 2009. Het gebruik van Natuurbrug Zanderij Crailoo door mens en dier. Alterra-rapport 1906. Alterra, Wageningen.

Van der Grift, E.A., F.W.G.A. Ottburg \& R.P.H. Snep. 2010. Toetsing ecologisch functioneren noordelijke toeloop Natuurbrug Laarderhoogt. Interne notitie. Alterra, Wageningen.

Van der Grift, E.A. \& R. van der Ree. 2015. Guidelines for evaluating use of wildlife crossing structures. In: Van der Ree, R., D.J. Smith \& C. Grilo (eds.). Handbook of Road Ecology: p. 119128. John Wiley \& Sons, Ltd.

Van der Grift, E.A. \& D.R. Lammertsma. 2017. Natuurbrug Laarderhoogt en woningbouw op CrailoZuid. Programma van Eisen voor woningbouw nabij de natuurbrug vanuit ecologisch perspectief. Rapport 2799. Wageningen Environmental Research, Wageningen.

Veen, P.J. \& G.J. Brandjes. 2000. Ecologische verbindingszone A1 Laren. Visie en aanbevelingen. Rapport 00-064. Bureau Waardenburg, Culemborg.

Waanders, M. 2020. Vegetatiekartering Laarderhoogt 2020. RPS advies en ingenieursbureau bv, Leerdam.

Wijsman, H. 2008. Gooise boommarters ondergronds. Zoogdier 19-4: 13-15.

Wijsman, H., S. Broekhuizen \& G. Müskens. 2014. Verspreiding van de boommarter in Nederland 1989-2012. Marterpassen XX: 24-29. 


\section{Bijlage 1 Vegetatie natuurverbinding}

In 2020 zijn er in Natuurverbinding Laarderhoogt vegetatieopnamen gemaakt en is de vegetatie gekarteerd. We presenteren hier kort de aangetroffen vegetatietypen, enkele plantensoorten die kenmerkend zijn voor het streefbeeld en enkele bijzondere plantensoorten die hier eigenlijk niet thuishoren. Voor een uitgebreide beschrijving van de gebruikten methoden en bevindingen, verwijzen we naar het rapport Vegetatiekartering Laarderhoogt 2020 (Waanders, 2020).

\section{Vegetatietypen in Natuurverbinding Laarderhoogt}

Binnen de natuurverbinding zijn vier vegetatietypen aangetroffen: (1) Calluna vulgaris-groep, (2) Betula pendula-groep, (3) Salix aurita-groep, en (4) Typha latifolia-groep. De ruimtelijke verdeling van deze typen over de natuurverbinding is te zien in Figuur B1.1. Binnen de natuurverbinding staat een aantal solitaire eiken met een grote kroonomvang. Ook deze zijn ingetekend op de kaart.

\section{Calluna vulgaris-groep}

De syntaxonomische plaats van deze groep komt op grond van de aangetroffen vegetatiesamenstelling overeen met de associatie Genisto anglicae-Callunetum (Associatie van struikheide en stekelbrem). Deze groep wordt gekenmerkt door de dominantie van Calluna vulgaris. Binnen de natuurverbinding komen in deze groep ook enkele bijzondere soorten voor. Op veel plaatsen is dat Genista pilosa en pleksgewijs soorten als Lotus corniculatus, Hypochaeris radicata en Filago minima. Het beeld van deze groep is homogeen, wat aangeeft dat er weinig variatie is in bodemtype en andere relevante standplaatsfactoren. Tijdens de inventarisatie is geen Erica tetralix waargenomen. Vermoedelijk is deze plaatselijk al wel aanwezig of zal zich in de nabije toekomst vestigen. Met een totale oppervlakte van $22.765 \mathrm{~m}^{2}$ is dit het grootste vegetatietype binnen de natuurverbinding.

\section{Betula pendula-groep}

De syntaxonomische plaats van deze groep komt overeen met de derivaatgemeenschap Prunus serotina (derivaatgemeenschap Amerikaanse vogelkers). Deze groep is ontstaan vanuit de aanplant en/of zaailingen van Betula pendula en zaailingen van Pinus sylvestris en Prunus serotina, en heeft zich voornamelijk gevestigd in het aangeplante bosplantsoen. De geplante soorten kunnen lokaal dominant aanwezig zijn. De ondergroei bestaat o.a. uit Agrostis cappilaris en Rubus spec. De Betula pendula-groep heeft een oppervlakte van $9.511 \mathrm{~m}^{2}$ binnen de natuurverbinding.

\section{Salix aurita-groep}

De syntaxonomische plaats van deze groep komt overeen met de associatie Salicetum auritae (associatie van geoorde wilg). Binnen deze groep nemen verschillende Salix-soorten een grote plaats in, met Salix aurita als meest dominante soort. De groep komt met name voor aan de randen van de natuurverbinding op de locaties waar bosplantsoen is aangeplant, daar waar de lucht- en bodemvochtigheid hoger zijn. Dit is bijvoorbeeld het geval langs de oostrand van de noordelijke toeloop, waar het bos van Landgoed Larenberg voor schaduwwerking zorgt en daarmee voor een hogere lucht- en ook bodemvochtigheid. Gezien de afwisseling tussen de Betula pendula-groep en Salix aurita-groep aan de westzijde van de natuurverbinding lijken de aangebrachte bodemtypen hier te variëren. De Salix aurita-groep, evenals de Betula pendula-groep, is ontwikkeld tot struweel dat de open heidevegetatie afschermt van de zone waar menselijk medegebruik is toegestaan, en heeft daarmee de functie van het aangeplante bosplantsoen voor een groot deel overgenomen. De totale oppervlakte van de Salix aurita-groep binnen de natuurverbinding is $5.340 \mathrm{~m}^{2}$.

\section{Typha latifolia-groep}

De groep wordt syntaxonomisch geplaatst in de rompgemeenschap Typha latifolia (rompgemeenschap van grote lisdodde). Deze aan water gebonden groep komt voor in de drie over de natuurverbinding verspreide poelen. In de poel in het tussengebied en de poel op de zuidelijke toeloop domineert Phragmites australis. Deze soort heeft zich hier sterk over de oeverzone uitgebreid. Maar die uitbreiding lijkt te stoppen waar de Calluna vulgaris-groep aanwezig is. Dit wijst mogelijk op een 
scherpe overgang tussen bodemtypes en de daarmee samenhangende vochthuishouding in de wortelzone. In beide poelen is onderwatervegetatie aangetroffen van vooral Potamogeton crispus. Dit wijst erop dat het water in de poelen matig voedselrijk is. Door de droogte is de poel op de noordelijke toeloop drooggevallen. De totale oppervlakte van deze groep binnen de natuurverbinding is $1.400 \mathrm{~m}^{2}$.

\section{Ontwikkelingen in de vegetatie}

In de natuurverbinding ontwikkelt de vegetatie naar verwachting. De heidevegetatie (Calluna vulgarisgroep) is een kruidenrijke heide geworden. Storingsvegetaties zoals soortenarme struisgrasvegetaties (uit de Agrostis vinealis/stolonifera-groep) en ruderale soorten die kenmerkend zijn voor de begintijd direct na de aanleg, hebben binnen Natuurverbinding Laarderhoogt wel gestaan, maar zijn inmiddels weer verdwenen. De grondsoort die bij de aanleg van de natuurverbinding gebruikt is op de plekken waar nu de Calluna vulgaris-groep aanwezig is, is blijkbaar de juiste om een kruidenrijke heidevegetatie mogelijk te maken. Hierdoor is er genoeg habitat aanwezig voor aan heide gebonden diersoorten. De poelen zijn goed ontwikkeld en ondanks de droogte is er water aanwezig in twee van de drie poelen, waardoor ook onderwatervegetatie tot ontwikkeling is gekomen. Hierdoor kunnen aan water gebonden dieren ook in droge tijden verblijven binnen de natuurverbinding. De Betula pendulaen Salix aurita-groep hebben zich ontwikkeld tot een struweel van circa vier meter hoog. Het heeft de afschermende functie van het bosplantsoen voor een groot deel overgenomen.

\section{Kenmerkende plantensoorten}

De verspreiding van kenmerkende plantensoorten in de natuurverbinding geeft een indicatie of de vegetatie zich ontwikkelt in de richting van het streefbeeld.

\section{Genista pilosa}

Dit is de kensoort van de associatie Genisto anglicae-Callunetum. De soort komt verspreid voor over de gehele natuurverbinding, daar waar ook Calluna vulgaris aanwezig is. Naast de aanwezige, meer algemene kruidensoorten, is deze plant belangrijk als voedselplant voor insecten.

\section{Genista anglica}

Deze bremsoort komt over de gehele natuurverbinding verspreid voor in de heidevegetaties (Calluna vulgaris-groep). Als vroegbloeier is de soort belangrijk als nectarbron voor insecten, zoals de bremzandbij die gespecialiseerd is op verschillende bremsoorten. Daarnaast zorgt deze soort voor meer structuur in de vegetatie, als er tenminste niet gemaaid wordt. Zolang de zode en de structuur van de vegetatie open blijven, kan deze soort zich ook verjongen. De soort kan vrij oud worden en zal zich bij passend beheer lang kunnen handhaven.

\section{Filago minima}

Deze soort komt algemeen voor in de heidevegetaties van de natuurverbinding. Een belangrijke reden is dat die heidevegetaties ook vijf jaar na de aanleg nog niet geheel gesloten zijn. Door die open vegetatiestructuur is de verwachting dat deze soort zich de komende jaren kan handhaven.

\section{Cladonia portentosa}

Deze korstmossoort komt vrij algemeen voor in Nederland. Korstmossen horen bij een goed ontwikkelde heidevegetatie. Dat deze soort zich heeft gevestigd binnen de natuurverbinding geeft aan dat de Calluna vulgaris-groep zich ontwikkelt tot een soortenrijkere heidevegetatie.

Hieracium laevigatum

Veel havikskruidsoorten horen van nature thuis in kruidenrijke heidevegetaties. Op één locatie binnen de natuurverbinding is Hieracium laevigatum aangetroffen. Doordat havikskruiden zich gemakkelijk kunnen verspreiden, is de verwachting dat deze soort zich gaat uitbreiden. Een andere havikskruidsoort die ook thuishoort in kruidenrijke heidevegetaties, Hieracium umbellatum, komt voor in de directe omgeving van de natuurverbinding. Deze soort zal zich naar verwachting op termijn ook vestigen binnen de natuurverbinding.

\section{Bijzondere soorten}

Bijzondere soorten zijn soorten die eigenlijk niet thuis horen of niet gewenst zijn in de vegetatietypen binnen de natuurverbinding. Het gaat dan om inheemse soorten die hier een afwijkende groeiplaats 
hebben of om exoten die een gevaar kunnen vormen voor het goed functioneren van de natuurverbinding.

\section{Veronica longifolia}

Binnen de natuurverbinding is één exemplaar van Veronica longifolia aangetroffen, in het bosplantsoen. Van nature komt deze ereprijssoort voor in matig voedselrijke, vochtige en enigszins verruigde delen van vochtige hooilanden. Daarnaast wordt de soort veel gekweekt als sierplant. Deze zelfbestuivende plant kan zich zowel via wortelstokken als met zaad verspreiden. Eenmaal hier terechtgekomen, zal de soort zich dan ook lang kunnen handhaven binnen de natuurverbinding. Naar verwachting zal de soort op termijn verdwijnen door de vegetatiesuccessie van open struweel naar bos of dicht struweel.

\section{Potentilla norvegica}

Deze ganzeriksoort komt aan de noordzijde van de natuurverbinding op één locatie voor in de heidevegetatie. Deze soort is in 1885 naar Nederland gebracht vanuit Noord-Europa en groeit op vochtige, basenarme en stikstofrijke bodem. Ze vormt zelden duurzame populaties, zodat de verwachting is dat deze soort niet lang zal standhouden binnen de natuurverbinding.

\section{Fallopia japonica}

De Japanse duizendknoop is op drie locaties in de natuurverbinding waargenomen, in de stobbewal en op locaties met bosplantsoen (Betula pendula-groep). De soort, die groeit in matig tot zeer voedselrijke bodems, kan snel grote oppervlakten innemen en daarbij andere plantensoorten verdringen. Zij zorgt daarmee voor een sterke afname van de lokale diversiteit aan plantensoorten.

Dit gevaar is ook aan de orde op delen van de natuurverbinding, vooral daar waar een meer voedselrijke bodem is aanwezig is. Vanwege zijn standplaatseisen zal deze invasieve exoot naar verwachting niet snel de voedselarme delen van de natuurverbinding kunnen koloniseren, waar de heidevegetaties staan.

\section{Prunus serotina}

In het zuidelijk deel van de natuurverbinding komt Prunus serotina op een aantal locaties vlakdekkend voor en pluksgewijs op een aantal andere plekken in de Betula pendula-groep. Het is mogelijk dat deze concurrentiekrachtige exoot zich gaat vestigen in de Calluna vulgaris-groep en daar gaat zorgen voor achteruitgang van de soortenrijkdom en van de voor dieren geschikte vegetatiestructuur. Dit zal vooral aan de orde zijn op de smallere delen van de heidevegetaties binnen de natuurverbinding. Het is belangrijk om hier met het beheer scherp oog op te houden. Eenmaal gevestigd is verdere verspreiding alleen te voorkomen door de planten met wortel en al te verwijderen. Een tweede remedie is het steeds zeer kort afmaaien van de struiken.

\section{Conclusies}

De vegetatie binnen de natuurverbinding heeft zich relatief snel ontwikkeld. De streefbeelden die voor de diverse zones gelden, zijn daarmee al voor een belangrijk deel gerealiseerd. Binnen de heidevegetaties van de natuurverbinding is de soortenrijkdom nog wel beperkt. Daarentegen zijn de soorten die er zijn waargenomen wel de kenmerkende soorten voor soorten- en structuurrijke heidevegetaties. Deze vegetaties hebben goede potenties om voor aan heide gebonden diersoorten (o.a. reptielen, dagvlinders, loopkevers) een effectieve natuurverbinding te bieden. De Japanse duizendknoop en Amerikaanse vogelkers, beide exoten met een sterk invasief karakter, kunnen een negatieve invloed hebben op de biodiversiteit. De struweelvegetaties kunnen door deze soorten overheerst gaan worden. Daarnaast bestaat er een kans dat de Amerikaanse vogelkers dominant wordt op de smalle stroken met soortenrijke heidevegetaties en deze vegetaties gaat verdringen. Hierdoor zal het functioneren van de natuurverbinding voor een aantal (kleinere) faunasoorten naar verwachting afnemen. 


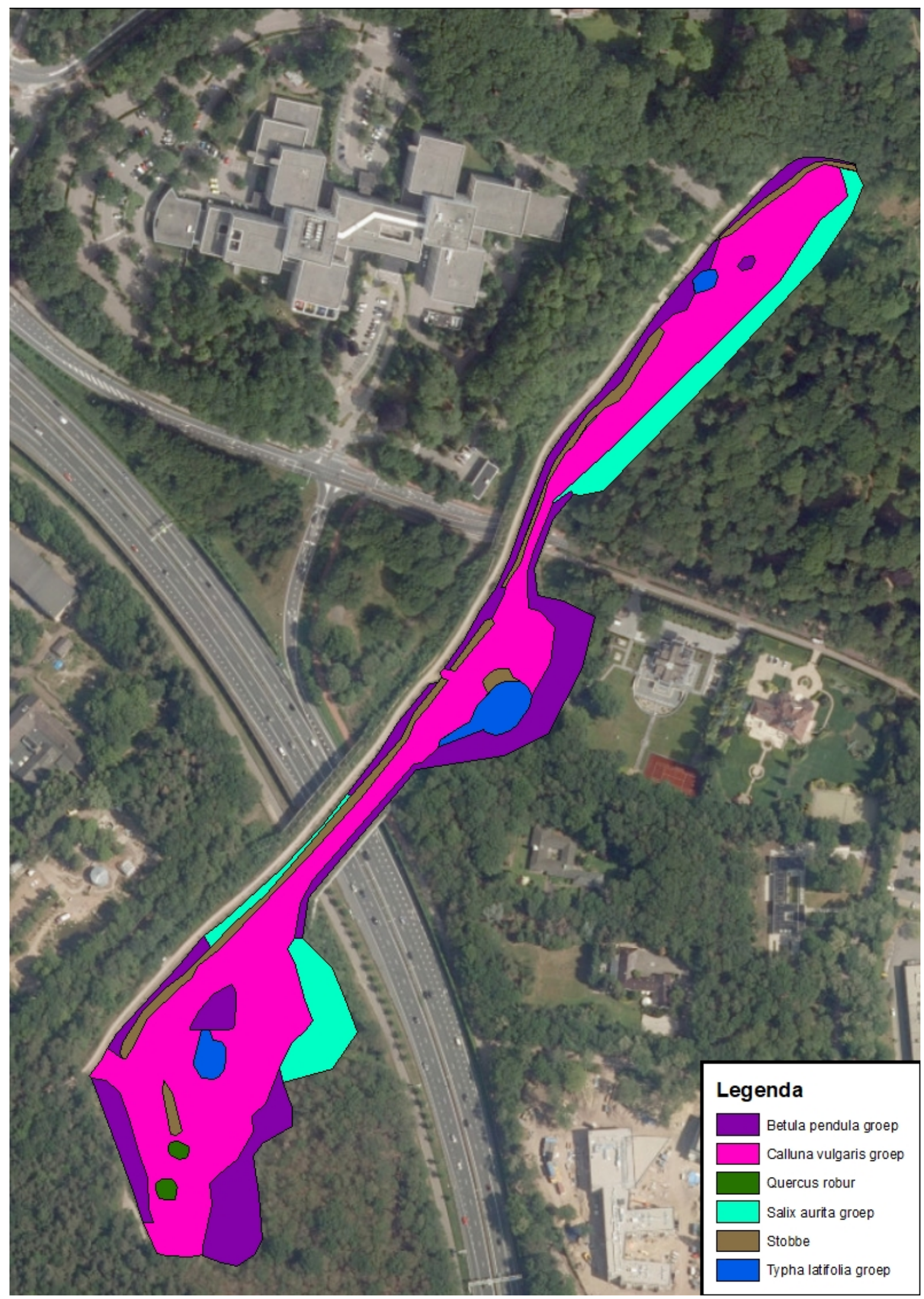

Figuur B1.1 Vegetatiekaart van Natuurverbinding Laarderhoogt. 
Wageningen Environmental Research Postbus 47

6700 AA Wageningen

T 0317480700

www.wur.nl/environmental-research

Wageningen Environmental Research Rapport 3044

ISSN 1566-7197
De missie van Wageningen University \& Research is 'To explore the potential of nature to improve the quality of life'. Binnen Wageningen University \& Research bundelen Wageningen University en gespecialiseerde onderzoeksinstituten van Stichting Wageningen Research hun krachten om bij te dragen aan de oplossing van belangrijke vragen in het domein van gezonde voeding en leefomgeving. Met ongeveer 30 vestigingen, 6.500 medewerkers ( $5.500 \mathrm{fte}$ ) en 12.500 studenten behoort Wageningen University \& Research wereldwijd tot de aansprekende kennisinstellingen binnen haar domein. De integrale benadering van de vraagstukken en de samenwerking tussen verschillende disciplines vormen het hart van de unieke Wageningen aanpak. 



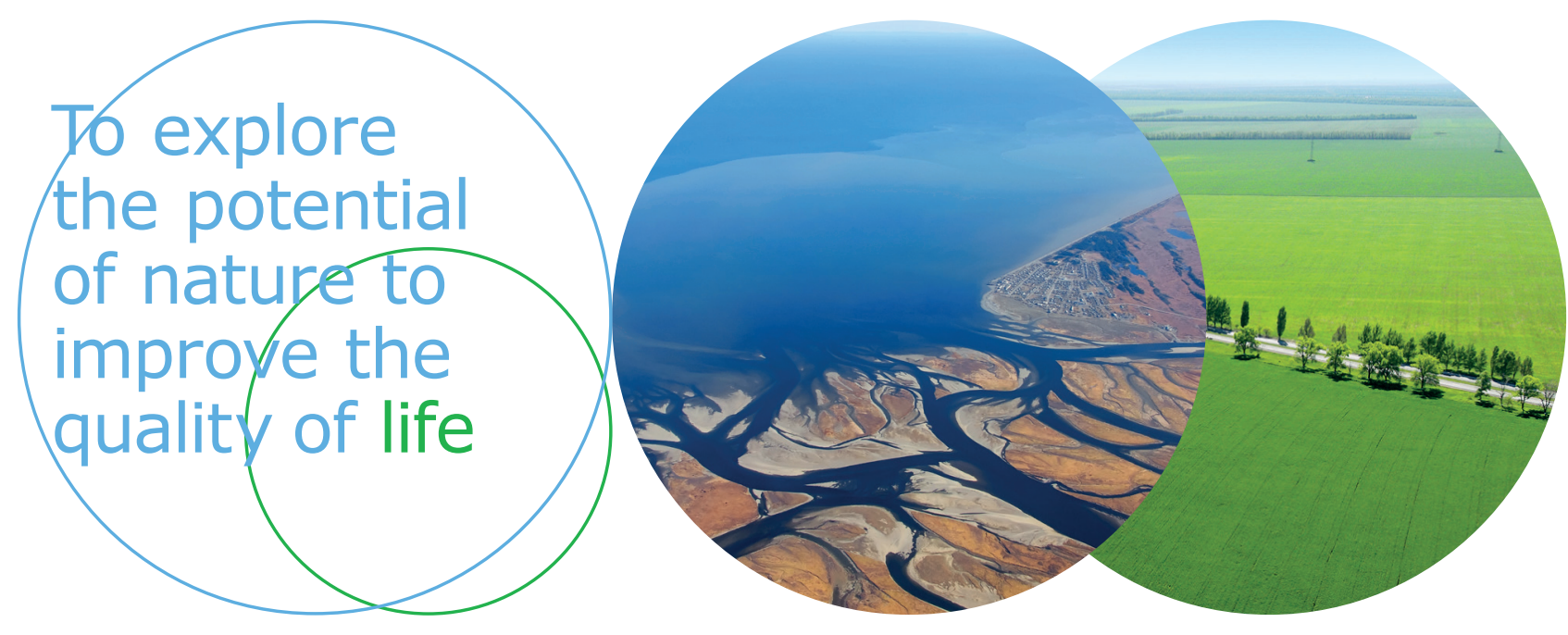

Wageningen Environmental Research Postbus 47

$6700 \mathrm{AB}$ Wageningen

T 317480700

www.wur.nl/environmental-research

Rapport 3044

ISSN 1566-7197
De missie van Wageningen University \& Research is 'To explore the potential of nature to improve the quality of life'. Binnen Wageningen University \& Research bundelen Wageningen University en gespecialiseerde onderzoeksinstituten van Stichting Wageningen Research hun krachten om bij te dragen aan de oplossing van belangrijke vragen in het domein van gezonde voeding en leefomgeving. Met ongeveer 30 vestigingen, 6.500 medewerkers ( $5.000 \mathrm{fte}$ ) en 12.500 studenten behoort Wageningen University \& Research wereldwijd tot de aansprekende kennisinstellingen binnen haar domein. De integrale benadering van de vraagstukken en de samenwerking tussen verschillende disciplines vormen het hart van de unieke Wageningen aanpak. 